\title{
DRAFT
}

\section{GUIDELINES FOR THE APPROVAL AND DESIGN OF NATURAL AND CONSTRUCTED TREATMENT WETLANDS FOR WATER QUALAYY IMPROVEMENT}

\section{FEBRUARY 1998}

Standards and Guidelines Branch Environmental Assessment Division Environmental Service 
Pub. No.: T/397

ISBN: $\quad 0-7785-0017-9$

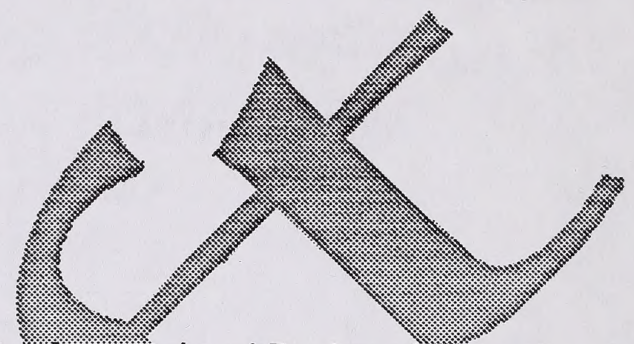

More information regarding the "Guidelines for the Avvroval and Design of Natural and Constructed Treatment of Wetlands for Water Quality Im:.0rovement", may be obtained by contacting:

Standards \& Guidelines Branch Environmental Assessment Division Environmental Service Alberta Environmental Protection $6^{\text {th }}$ Floor, $9820-106^{\text {th }}$ Street Edmonton, Alberta T5K 2J6

Phone: (403) 427-6102.

Primany Contact: Karu Chinniah Standards and Cuidelines Eranch Alberta Environmenta! Protection $6^{\text {th }}$ Floor, $9820-106$ th $^{\text {S Stroet }}$

Edmonton, Alberta T5K 2.56

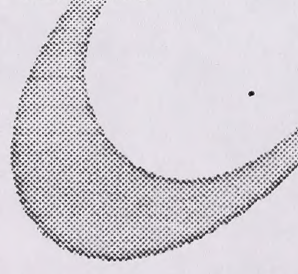




\section{Foreword and Acknowledgements}

Use of wetlands for water quality improvement is increasingly popular. This manual contains guidelines for the evaluation, design and operation of natural and constructed treatment wetlands for water quality improvement. The guidelines are intended to assist both the regulator and the designer. To the regulator, they are a means of specifying certain requirements are considered critical in the evaluation and the approval of wetlands for water qu lity ingement. To the designer, they provide useful guidance as to what the regulator ex $\$$ terms of the overall design of the facility.

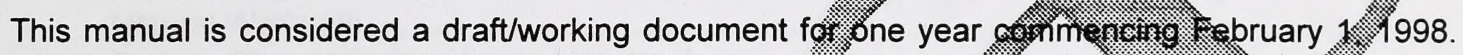
During this period, Alberta Environmental Protection wist be please

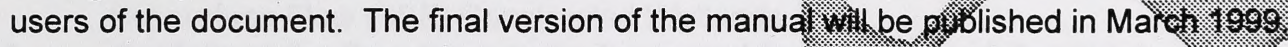

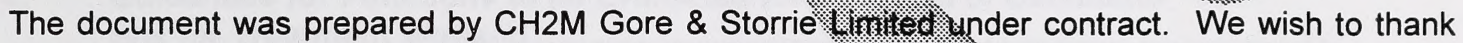

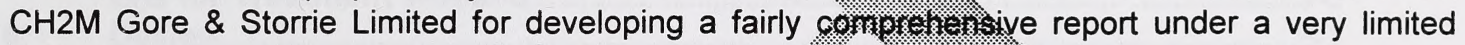
budget.

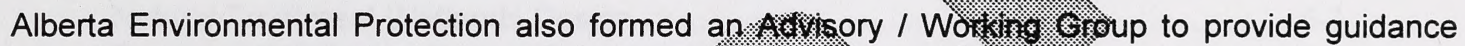

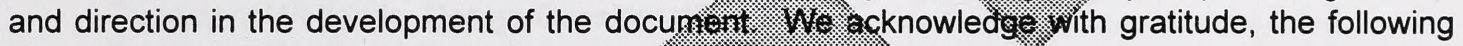
who participated in the process:

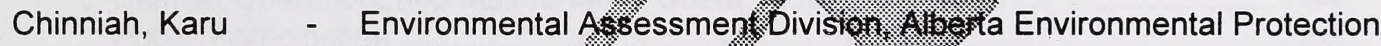

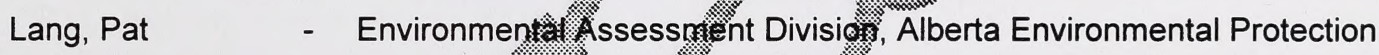

Lungle, Ken $\quad$ - Wildlife Maragement:

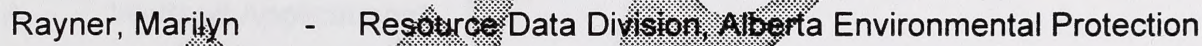

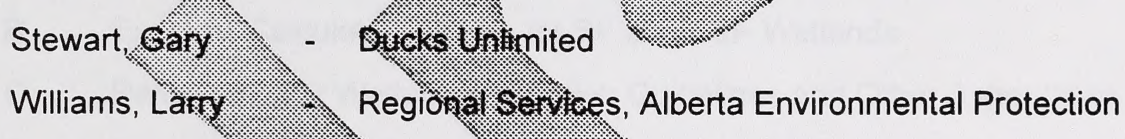





\section{Contents}

Section

Forward and Acknowledgements

1. Introduction

2. Approach

3. Questionnaire

4. Preliminary Feasibility of Treatment Wetlands for Wastewa to folt thing

Natural Wetlands

Surface Flow (SF) Constructed Wetlands

Subsurface Flow (SSF) Constructed Wetlands

Guidelines for Functions to be Evaluated for Approval of Candidate

5. Guidelines for Functions to

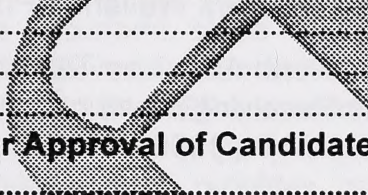

6. Design

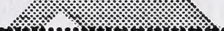

Constructed Treatment Wetlands Design

Natural Treatment Wetlands Design

Treatment Wetlands: Design Considerations

Treatment Wetlands Operation

Capital, Operation, and Maintenanee Costs

Public Participation

\section{Appendices}

A Wetland Applications:

B Exanpie Calculation Tabtes for SF and SSF Wetlands

C References for Wetlarid Eiv:atuation Guidelines and Other Appendices

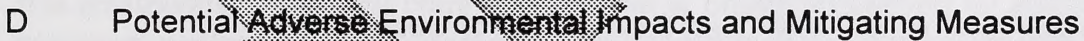

E Rare Pैant Species:

F Landscape Types an:d liocalities Potentially Indicative of Significant Plant Species

G Habitat Matrix for Breeding Fishes, Amphibians and Reptiles, Birds, and Mammals of Alberta

H. Significant Arimal Species of Alberta

1. Anrofated Bibliography for Wetland Evaluations

J Nethods to Design and Construct Wetland Systems

K Questions and Concerns that Have Been Raised About Wetlands 


\section{Tables}

Number

Page

3.1 Description of Candidate Wastewater Treatment Wetland - Alberta

4.1 Alberta Environmental Protection - Wetlands Guidelines: Surface Flow (SF) Treatment Wetland - Preliminary Feasibility Calculation Sheet

4.2 Alberta Environmental Protection - Wetlands Guidelines subsurfick Flow (SSF) Treatment Wetland - Preliminary Feasibills Ealculation

4.3 Summary of North American Treatment Wetland O wational R. for Systems Receiving Municipal and Industrial Was rivater.ind Stormwater (Kadlec and Knight, 1996)

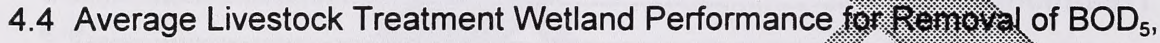
TSS, $\mathrm{NH}_{4}-\mathrm{N}$, and TN (Knight, Payne, Pries, Borer, arke, 4-6

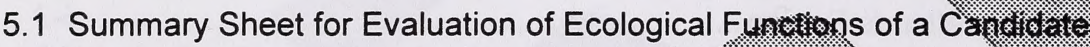

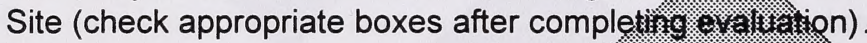

\section{Figures}

Number
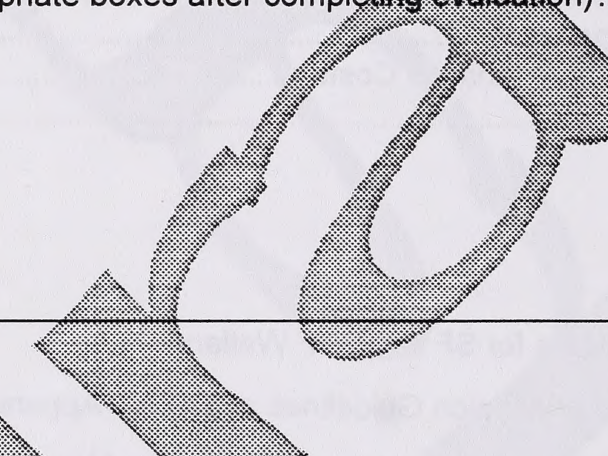

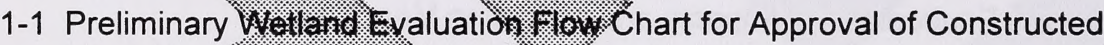

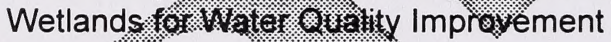

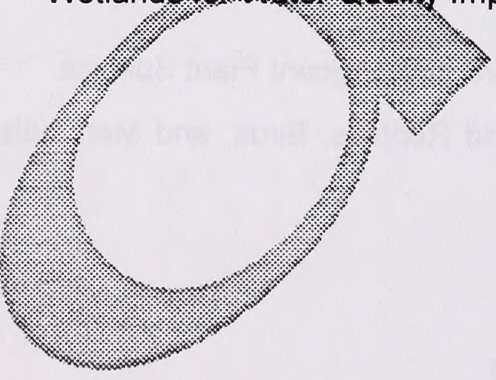




\section{Introduction}

Alberta Environmental Protection (AEP) occasionally receives requests from municipalities and consultants to use natural wetland areas such as marshes, swamps, and sloughs for polishing of treated municipal wastewater. There has also been considerable interest in the use of constructed treatment wetlands for water quality improvement. This manual was prepared to provide standardized guidelines for the approval of candidate treatment wetlan.sites by the Alberta Environmental Protection Regional Services Engineers and to videsign guidance to agencies and consultants for natural and constructed wetlands $f_{6}$. \#istowater polishing. A brief description of several potential wetland applications is sentectix $A$.

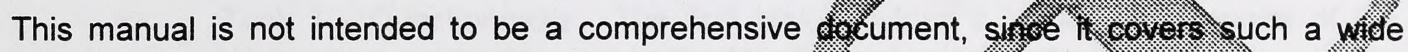

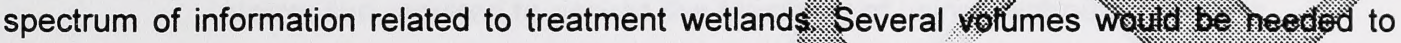

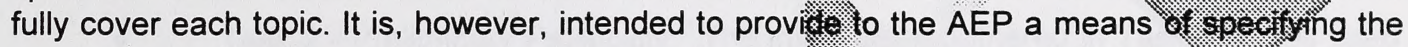
requirements that are considered necessary for the keatment or polishing of wastewater in constructed or natural treatment wetlands. The manisal also provides municipalities and consultants with an outline of the expectations of the AE in terms of overall system design and in terms of procedures that must be followed in selecting wetlands for the treatment or polishing of wastewater.

It is important to note that AEP will allow com only with restricted access as part of the wastewater treatment process, will be required at the outlet of the wetlans.

To provide the maximum protection : For natusal wetlans that are under consideration for conversion to treatment wetlands, 6 , hydraikic and nisient loading to the wetland will be minimized to reduce the potenfiaf for neszative impocts on the wetland. The wastewater treatment plant discharge to the wetland will ge resistifed to consistently meet tertiary or high

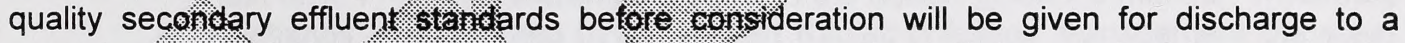

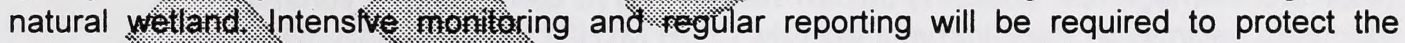
integrity of

The wastewater meanz:

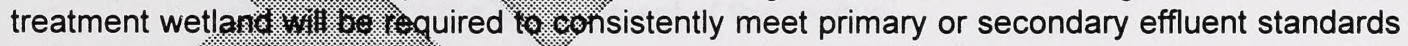

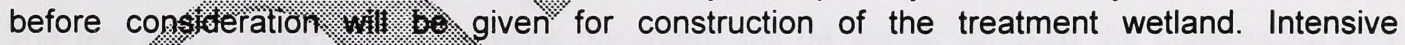

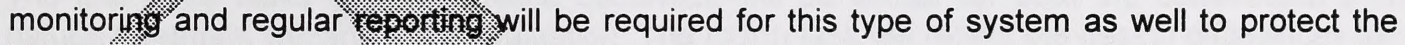
integrify of the wetland.

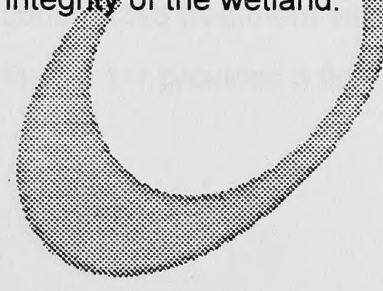





\section{Approach}

This document will enable the AEP to screen projects that are presented for approval and provide preliminary guidance for the design process. To accomplish this, a step-by-step approach to the evaluation and design process has been prepared. This allows for an evaluation process that will begin with the least-cost stages that are, for the most.part, desktop evaluations and move to those stages that are more labour-intensive and require field investigations.

The document is divided into several tasks as follows:

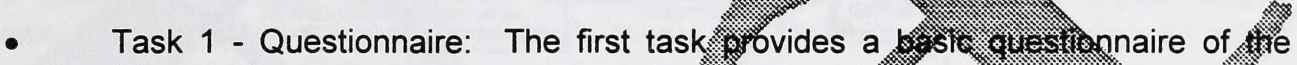
information required to assess the feasibitity of using reatmen wettanids.

- Task 2 - Preliminary Feasibility: The inton mation gathered in Task I will be used in the second task to determine the feasibulity of using a treatment wetland for the application that is being investigated.

- $\quad$ Task 3 - Evaluation Guideline: An evatuation of tre ofoposed site will follow to determine if the proposed wetland site is of treal. numicipal, or provincial significance due to factors such 25 the occurrence or an endangered wildlife species, the existence of a heronty on the oroperty, of the existence of a cultural heritage site within the bounsaries of the oroposed : Yetland site. Support for this latter effort will likely be required from tike orowincial government to properly implement the evaluation process.

- Task 4 - Design Guitiance: Basic guidane for the design of a treatment wetland system in the form of a cheskist of critical factors to consider is provided in the last task. Fregident reference is matie to the design guidance manual "Treatment Wetlands". co authored by D. Rowert Kadlec (Wetland Management Services) and Dr. Rober Inight (CH2M HILL) who are internationally recognized treatment wertands experts. This text is considered to be the most comprehensive treatrint wetlands tocument published to date and is the main source of intermation for the development of this manual.

The first three tasks of tre govideline document will be similar for both the constructed and natural treatment wetlarta initia evaluation. The fourth task will reflect the design differences for constructed treatment wettants and engineered natural wetlands.

Figitre $1-1$ provides a flow diagram of the evaluation process as described above.

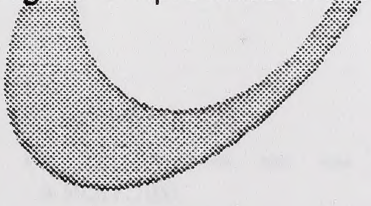


FIGURE 1-1

Preliminary Wetland Evaluation Flow Chart for Approval of Constructed Wetlands FOR WATER QUALITY IMPROVEMENT

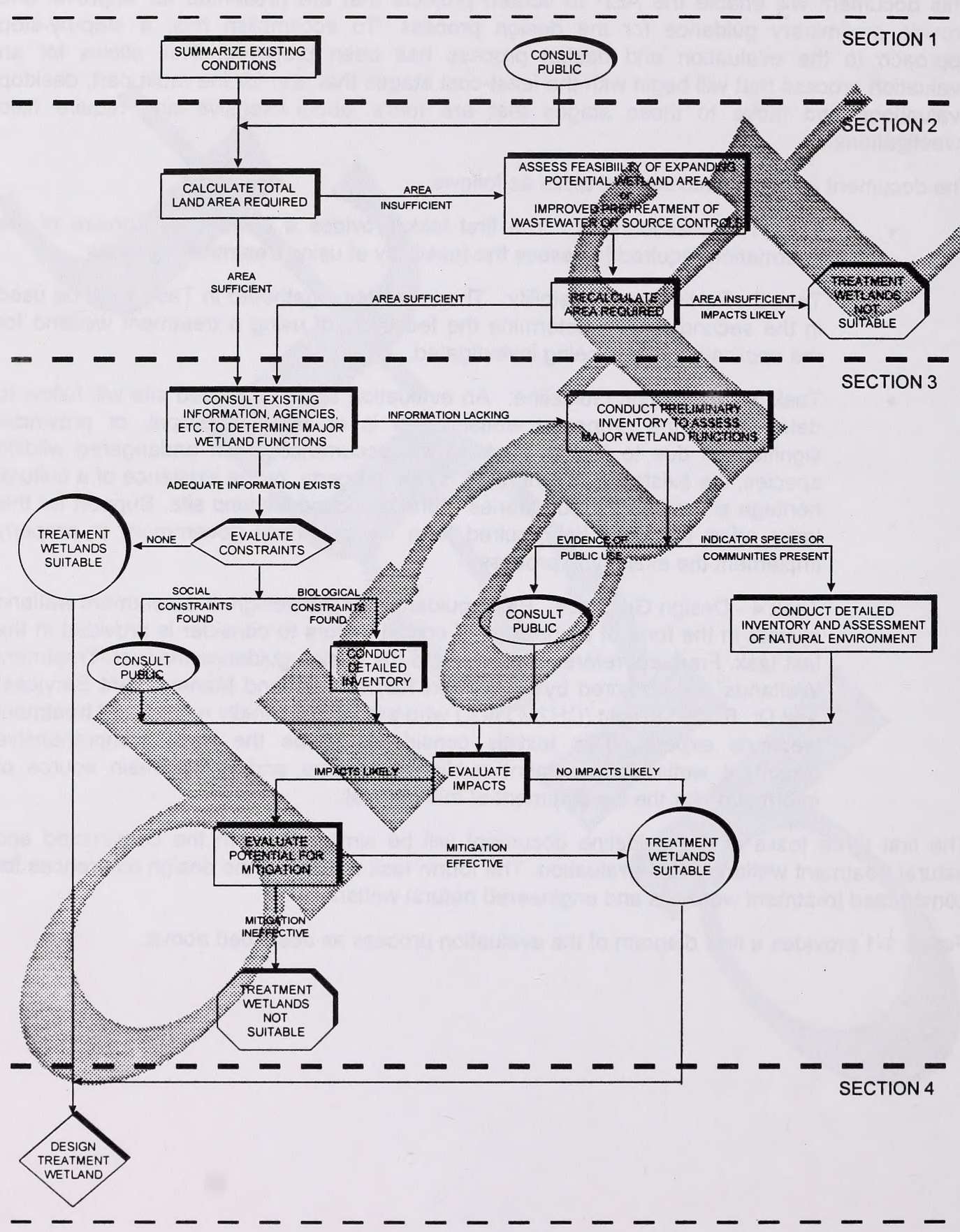




\section{Questionnaire}

The questionnaire presented in Table 3.1 documents the basic information required to determine the feasibility of using a treatment wetland for polishing of a wide variety of industrial, agricultural, and municipal wastewater discharges. Included is site location, type of wastewater pretreatment, pretreated water quality, hydraulic loading, soil conditions, land availability, effluent water quality objectives (must the discharge criteria be met at the point 4 inflow to the wetland or at the point of outflow?), current land use, topography, clinfiric factors. If a natural wetland is considered for treatment purposes, additional $\&$ iriontion that may be required includes the type of wetland, dominant vegetaton, exititis Itormwater and/or wastewater input sources, soil conditions (soils map), aks feasibility of constrituting an inflew and/or an outflow structure if required.

Upon completion of the questionnaire, the collected dist must be reviewed, and contaminant loadings determined and compared to provincial geidseines. Further investigation will be warranted if a particular contaminant is determined to be 01 . condern. Further treatment of the wastewater may be required prior to inflow to the wetlazd s.sitem either in the existing wastewater treatment plant or as a separate treatmentunit.

It must also be determined if portions of the treatrien: wetland systern yot be accessible to the public. This will have some bearing on the type. or trealmen wetland satat will be most suited to the treated wastewater source. Control of public akesss. uil be by quired where exposure to partially treated wastewater may result in ifiness. Tysically isi. of exposure is minimized toward the outflow end of the system and wifl likely be Suitable rowsublic enjoyment for hiking and wildlife viewing.

The types of wetlands that are best suited for the appleations in Alberta are presented in the next task.

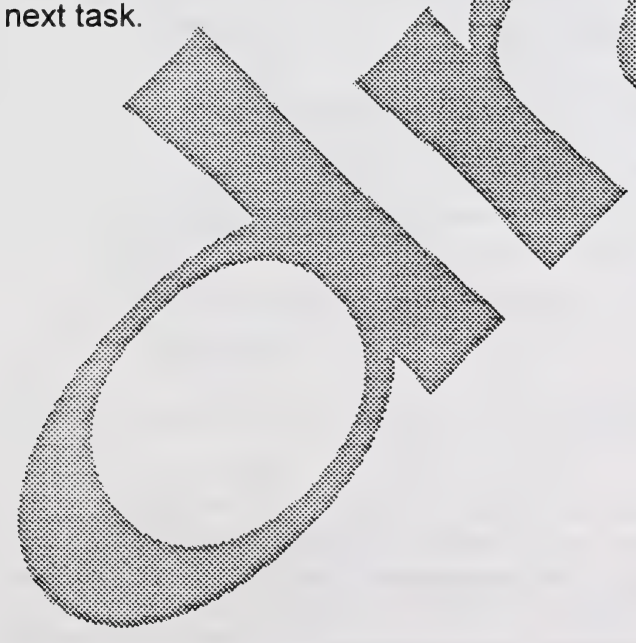


Table 3.1 - Description of Candidate Wastewater Treatment Wetland - Alberta

\section{Potential Wetland Location Site Data}

Site Name:

City/Community:

Wastewater Source:

Municipal:

(describe)

Industrial:

Other:

Other Anticipated Wetland Uses: nature study

Key/sensitive wildlife habitat:

Wastewater Pretreatment:

Stormwater:

\section{Watershed Area:}

Runoff Coefficient:

Design Flow:

Site Substrate Material (eg. sand, clay, muck, sandy clay, clayey.x.1.t.

Permeability:

$\%$ Vegetation Cover: submergent _ emergent

Land Area Available:

Proximity to Water/Wastewater Source:

Current Site Land Use:

Adjacent Land Use (north):

Adjacent Land Use (east):

Adjacent Land Use (south):

Adjacent Land Use (west):
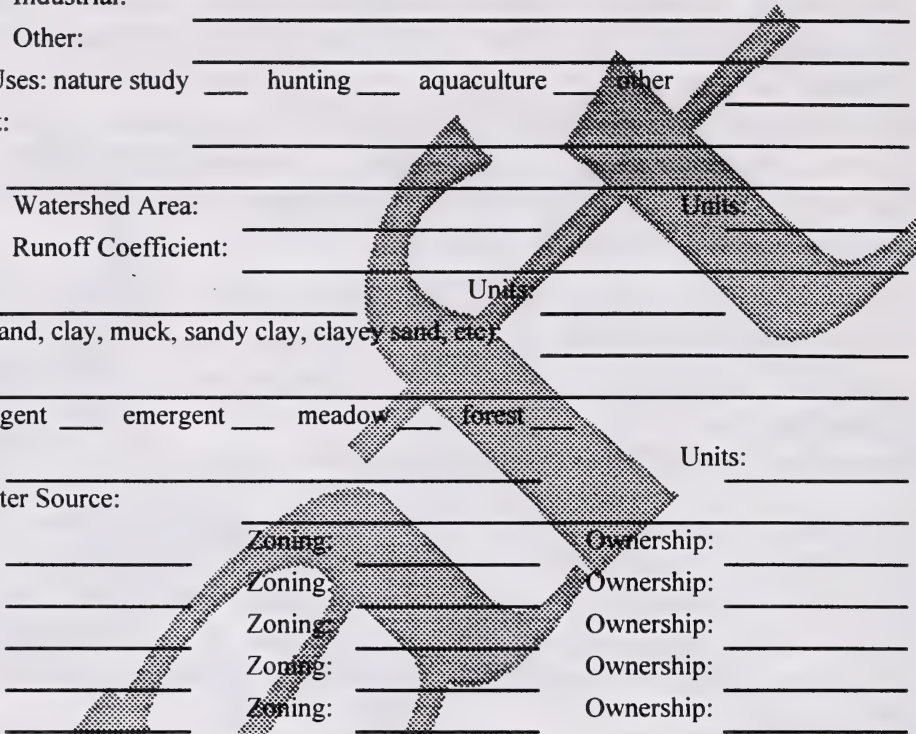

Population:

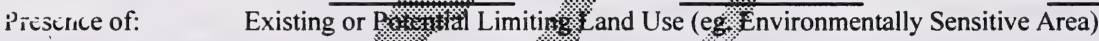

Protected W

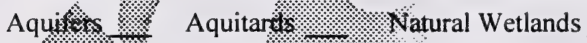

$\% \rho$ f. v.

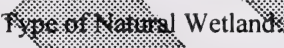

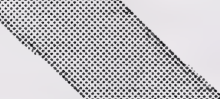

Y. Open Water

(1.2.1.20

Forest

Floating Aquatic

Otho

(4)

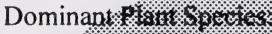

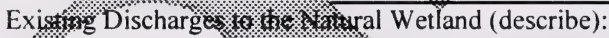

Rike Topography:

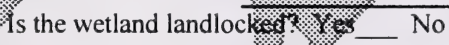

If no, what water body $/$ ill/does the treatment wetland discharge to?

Water body classificiation:

Wetland outlet losizison and description:

Define waterstivoforder:

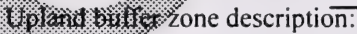

Area:

Width: 
Table 3.1 (Continued) - Description of Candidate Wastewater Treatment Wetland - Alberta

Monitoring - Average Data - Potential Discharge to the Treatment Wetland

Wastewater Treatment Plant Effluent/Stormwater Discharge

Operating Season (months):

Period of Record :

Start (Year) End (Year)

Years in Service:

Average Flow ( $\mathrm{m}^{3} /$ day):

Parameter

Concentration

$\mathrm{BOD}_{5}$

TSS

TDS

Turbidity

$\mathrm{NH}_{4}-\mathrm{N}$

$\mathrm{NO}_{3}-\mathrm{N}+\mathrm{NO}_{2}-\mathrm{N}$

Total Nitrogen

TKN

Organic Nitrogen

Total P

Filtered $\mathrm{P}$

Dissolved Oxygen

Redox Potential

Sulfate/Sulfide

Conductivity

Alkalinity

$\mathrm{pH}$

Tempexature

Chlofito

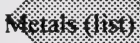

vi

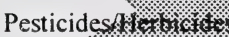

(list)

Organics (list)

Fecal Coliform

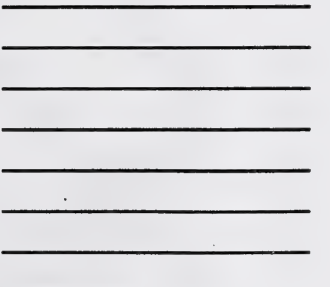

$\mathrm{mg} / \mathrm{L}$

$\mathrm{mg} / \mathrm{L}$

$\mathrm{mg} / \mathrm{L}$

$\mathrm{mg} / \mathrm{L}$

$\mathrm{mg} / \mathrm{L}$

$\mathrm{mg} / \mathrm{L}$

$\mathrm{mg} / \mathrm{J}$

13.

$\mathrm{mg} / \mathrm{L}$

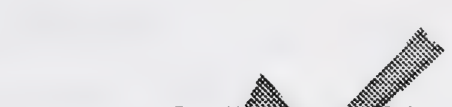

nits

$\mathrm{g} / \mathrm{L}$

$\mathrm{g} / \mathrm{L}$

$\mathrm{g} / \mathrm{L}$

L
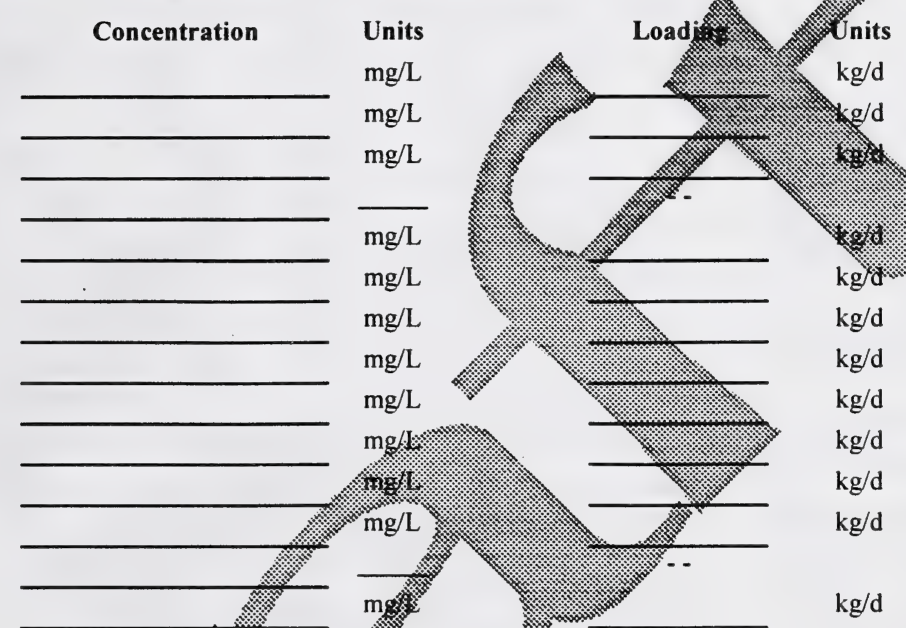

……

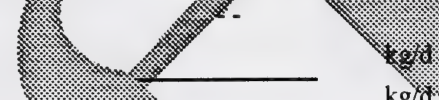

$\mathrm{kg} / \mathrm{d}^{2}$

$\mathrm{kg} / \mathrm{d}$

$\mathrm{kg} / \mathrm{d}$

$\mathrm{kg} / \mathrm{d}$

$\mathrm{kg} / \mathrm{d}$

$\mathrm{kg} / \mathrm{d}$

$\mathrm{kg} / \mathrm{d}$

$\mathrm{kg} / \mathrm{d}$

$\mathrm{kg} / \mathrm{d}$

mg/L

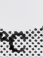

\%

mit

$\mathrm{kg} / \mathrm{d}$

E.coli
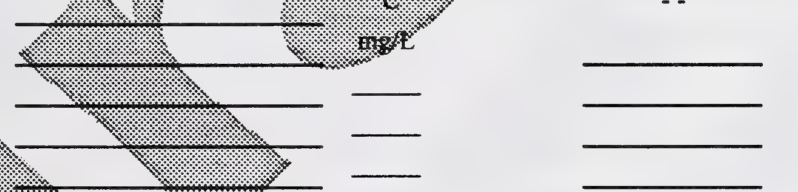

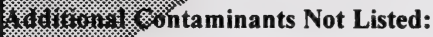


Table 3.1 (Continued) - Description of Candidate Wastewater Treatment Wetland - Alberta

Monitoring - Average Data - Existing Natural Wetland Outflow

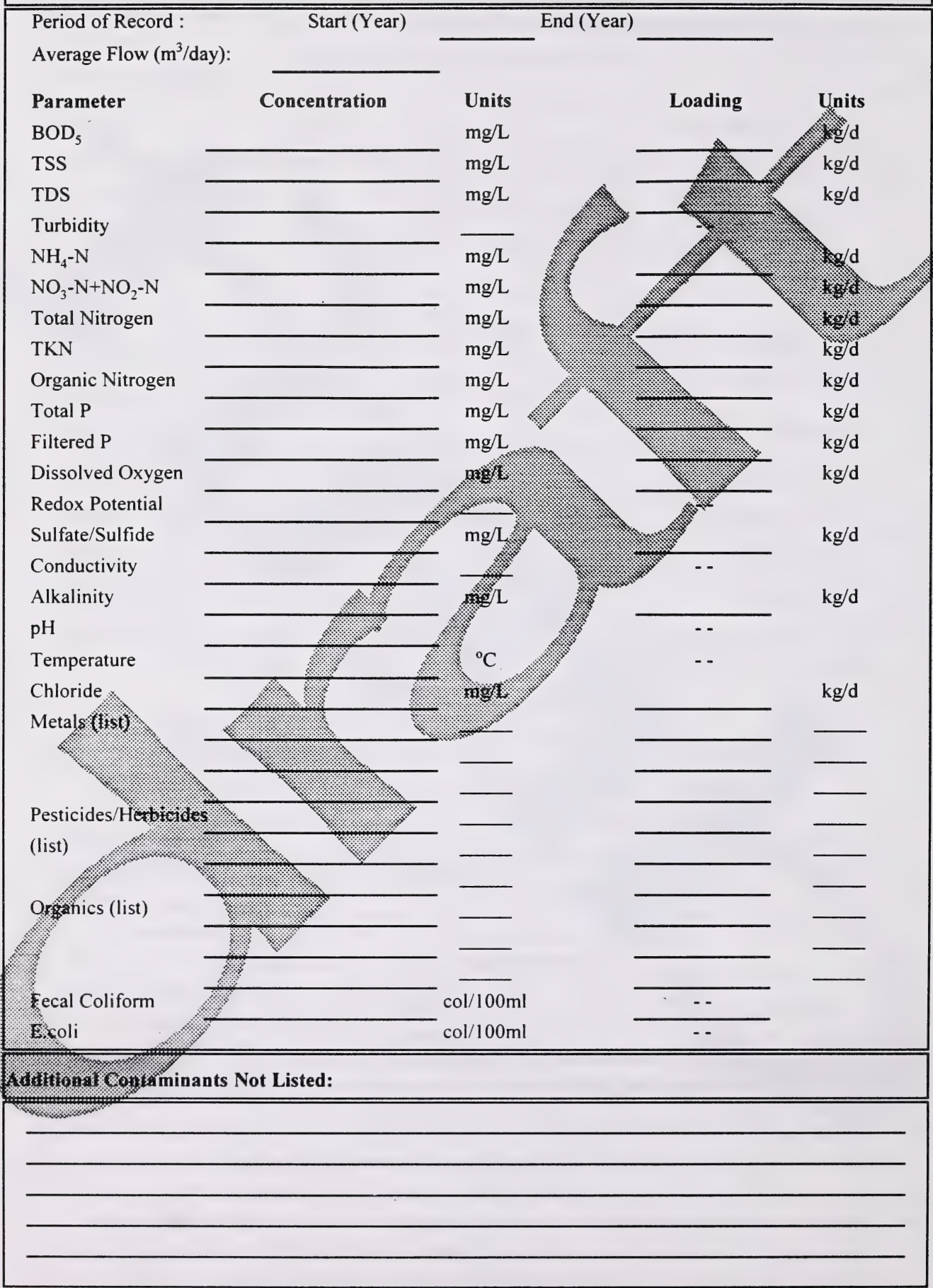


Table 3.1 (continued) - Description of Candidate Wastewater Treatment Wetland - Alberta

\section{Treatment Wetland System Outflow Targets}

Discharge criteria to be met at wetland inflow or wetland outflow

Dissolved Oxygen $(\mathrm{mg} / \mathrm{L})$ :

$\mathrm{pH}$ :

$\mathrm{BOD}_{5}(\mathrm{mg} / \mathrm{L})$ :

TSS (mg/L):

$\mathrm{NH}_{4}-\mathrm{N}(\mathrm{mg} / \mathrm{L})$ :

Total Nitrogen (mg/L):

$\mathrm{TP}$ (mg/L):

Fecal Coliform (col/100 mL)

Approved Flow (per day, week, month, year)

Approval Duration:

annual seasonal

monthly_otheriber.

\section{Treatment Wetland Contact Details}

Last Name:

First Name:

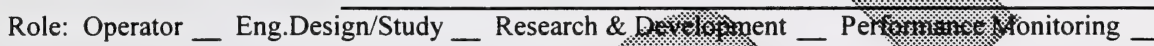
Organization:

Address:

Phone\#:

Fax\#:

\section{Climatic Factors}

Avg \# of Frost-free Days

Avg Annuik Temperatur

A vg $w_{1 n t a l}$ maperature

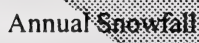

Annual Raindis

Annual Prewoulution

Elevation

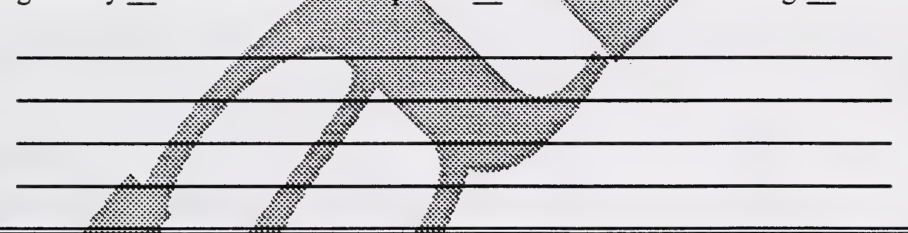

Coing

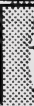

.

$\ldots$

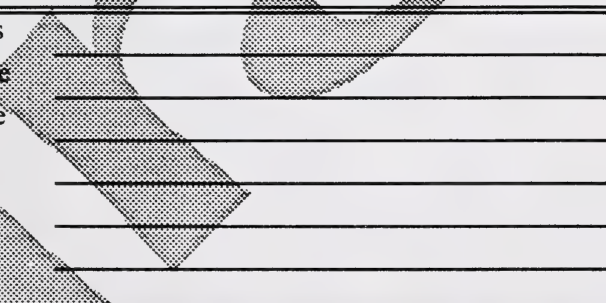

Units:

Units:

Units:

Units:

Units:

Units: 



\section{Preliminary Feasibility of Treatment Wetlands for Wastewater Polishing}

In this task, a portion of the information that was gathered in the first task will be processed. The wetland area requirement will be determined and areal and contaminant loading rates will be compared with reported values from other treatment wetland systems. At point, it will likely be determined whether the land area available will provide adeste seatment to meet the effluent objectives. If the total land area required is novailabl. 3 .

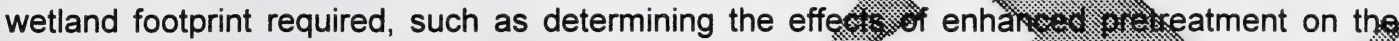
wetland area requirement, are presented. A copy of a fical spreasinte

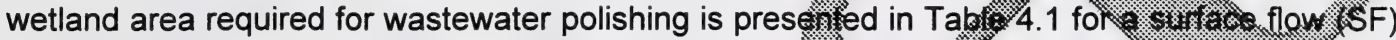

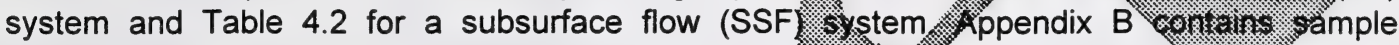
completed spread sheets.

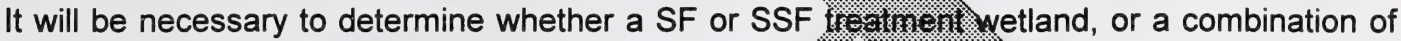

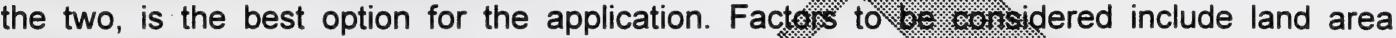
availability, funding, and potential for physical contact by ares. sisions with the treatment process.

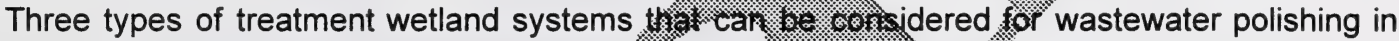
Alberta include:

- Natural wetlands

- Surface flow construedes wetland

- Subsurface flow cofrsizercted witilands

Each of these alternatives brieflyis:describe\& owtow.

\section{Natural Wetlands}

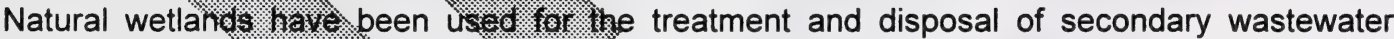

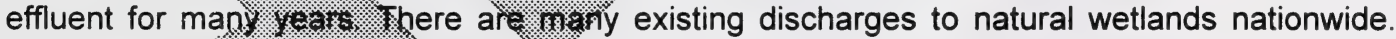

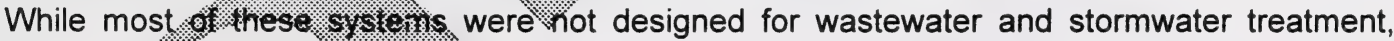
studies of some naturatwertang have led to an understanding of the natural ability of wetland ecosystems for pollutant assingilistion and to the design of new natural water treatment systems.

The groper use of a natural wetlands system for the treatment of secondary wastewater or stornwater involves a fumber of considerations. Research indicates that matching hydraulic loads to the hydropeinod requirements and tolerances of the dominant wetlands vegetation sperses reduces the sobtential for vegetation changes. At high organic and nutrient loadings, some natural welfanus may be significantly degraded. Plant species are likely to shift to herbaceous mars. specoss.such as cattails (Typha spp.). Optimal treatment occurs when the pretreated water is well-distributed throughout the wetland and travels through as sheet flow. Ideally, alternative discharge areas or "treatment cells" are used to reduce the hydraulic and nutrient loadings that might otherwise affect the vegetation community in the treatment cells. 
Table 4.1 - Alberta Environmental Protection - Wetlands Guidelines Surface Flow (SF) Treatment Wetland - Preliminary Feasibility Calculation Shget Instructions: Fill in the single outline boxes with data gathered in Section 1, then calculate the values for the Location:

Design Flow, $\mathrm{m}^{3} / \mathrm{d}$

Influent Concentration

Target Effluent Concentration

Wetland background limit, $\mathrm{mg} / \mathrm{L}$ for TSS, $C^{*}=7.8+0.063 C$ for BOD, $C^{*}=3.5+0.053 C_{i}$ Areal rate constant @ $20^{\circ} \mathrm{C}, \mathrm{m} / \mathrm{yr}$. Required wetland area, ha $A=\left(\frac{0.0365 \times Q}{k}\right) \times \ln \left(\frac{C_{1}-C^{*}}{C_{e}-C^{*}}\right)$

Effluent concentration, $\mathrm{mg} / \mathrm{L}$ via $k$ - ${ }^{*}$ model

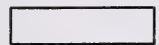

$k=$

$A=$

$c_{0}=$

$\mathrm{C}^{*}=$
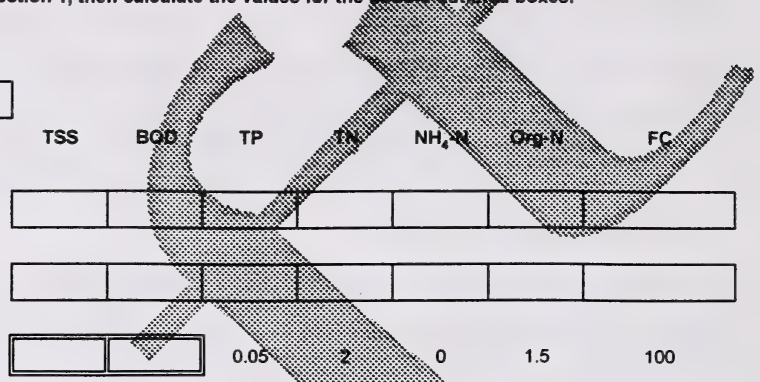

0.05

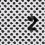

\%

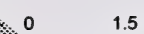

100

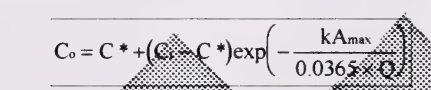

C. @. Wyum area =

(1)

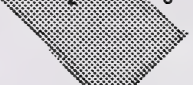

1.5

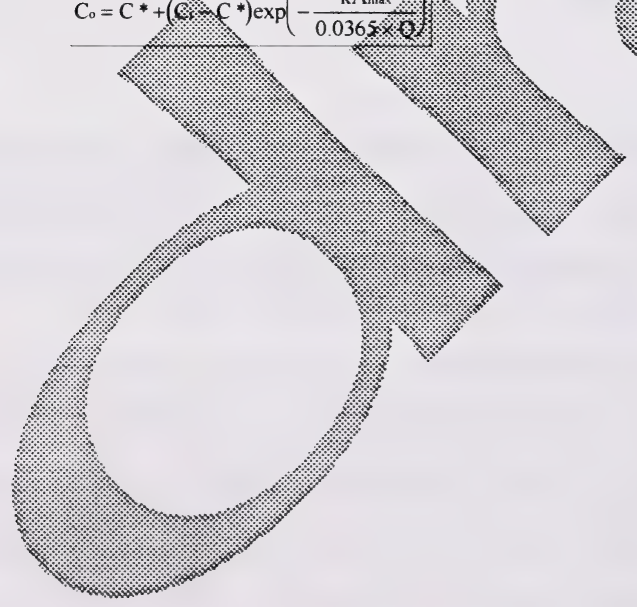

\%30

17

77

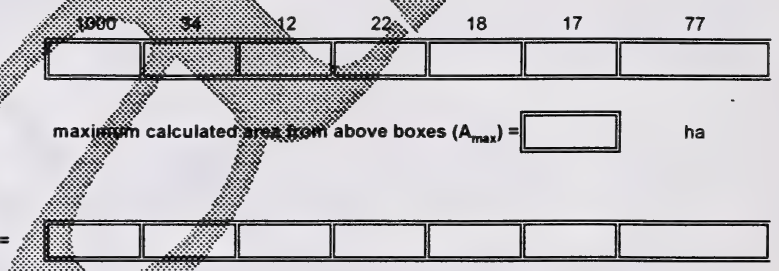


Table 4.2 - Alberta Environmental Protection - Wetlands Guidelines Subsurface Flow (SSF) Treatment Wetland - Preliminary Feasibility Caiculation Sheet

Instructions: Fill in the single outline boxes with data gathered in Section 1, then calculate the values for the doubl

Location:

Design Flow, $\mathrm{m}^{3} / \mathrm{d}$

$\mathbf{Q}=$

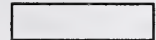

Influent Concentration

$c_{1}=$

Target Effluent Concentration

$c_{.}=$

$C^{*}=$

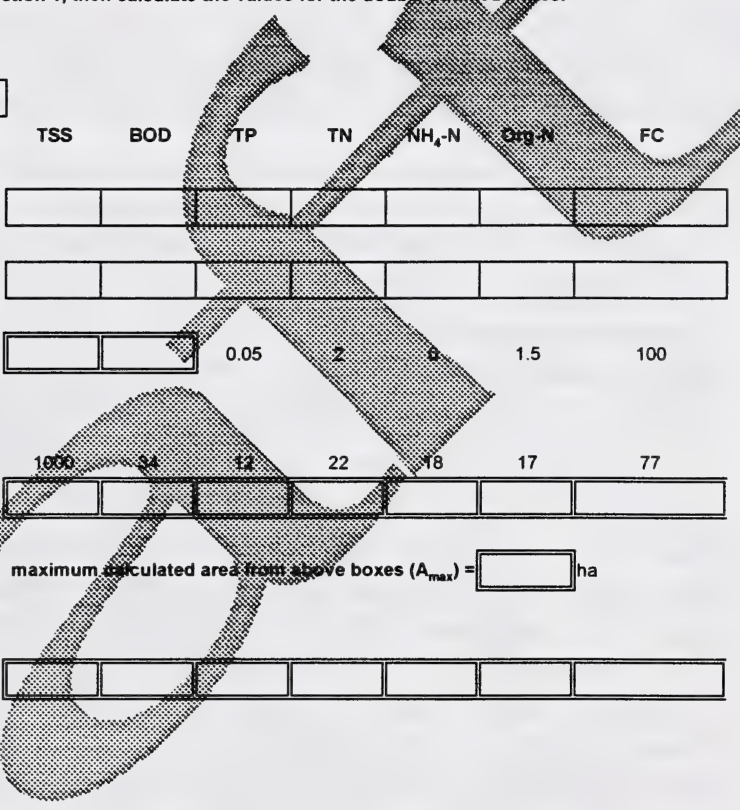

Wetland background limit, $\mathrm{mg} / \mathrm{L}$

for TSS, $C^{*}=7.8+0.063 C_{1}$

for $\mathrm{BOD}, \mathrm{C}^{*}=3.5+0.053 \mathrm{C}$

Areal rate constant @ $20^{\circ} \mathrm{C}, \mathrm{m} / \mathrm{yr}$.

Required wetland area, ha

$$
A=\left(\frac{0.0365 \times Q}{k}\right) \times \ln \left(\frac{C_{i}-C^{*}}{C_{e}-C^{*}}\right)
$$

Effluent concentration, $\mathrm{mg} /$ ـ

$$
\text { via } \mathrm{k}-\mathrm{C}^{*} \text { model }
$$

C。 (1) maximarea =

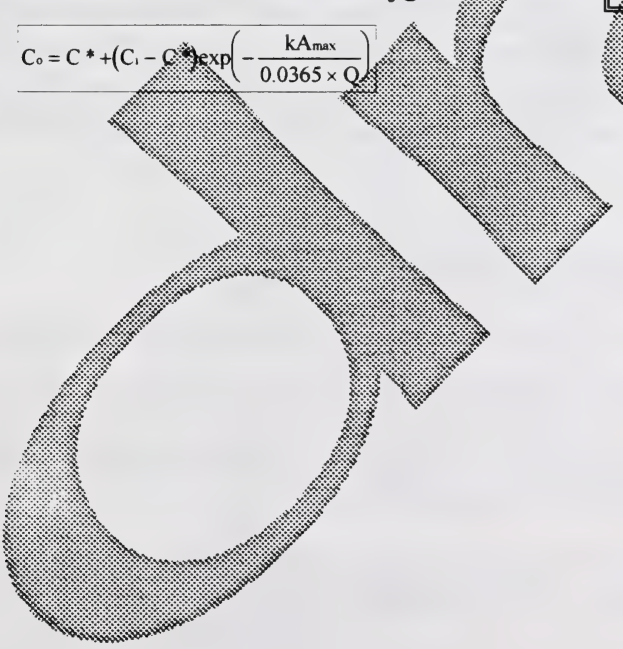


Definitive studies of the performance of natural wetlands for water quality enhancement have been completed. These studies demonstrate that, through careful design, some natural wetlands can consistently and cost-effectively provide advanced treatment of wastewater and stormwater constituents.

\section{Surface Flow (SF) Constructed Wetlands}

Constructed wetlands usually are shallow, man-made impoundments planted emergent, rooted vegetation. These wetlands may be planted manually or naturall r lonizi by "volunteer" plant communities. Some constructed wetlands contain mon cultures *i: \&atialis (Typha spp.) or

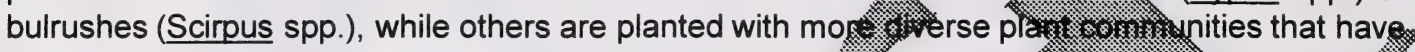
greater stability under changing seasonal and water quality sonditions.

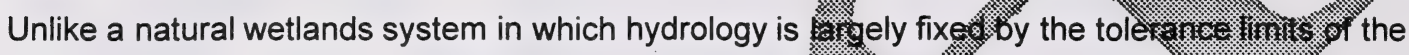
existing plant community, a constructed wetland can be desigrted to regulate watler dopth and residence time, two of the most important factors in wetlais is t: estment design. Also, the design of constructed wetland systems can feature parallel cells or celits in series. Such a system can be operated to rotate discharge points or to use slightly different tipa zr:-7:t capabilities of the various available plant species groups. SF constructed wetlands have seratively low construction, operation, and maintenance costs compared with cortventional advankes: : reatment technologies.

The emergent plants of SF wetlands are not traveste: 80 lemove nutrients. Instead, the natural assimilative capacity of the microbial flora (bacteria and fungi) that attach to the plants provides efficient and reliable removal of biodegradable organics and nitrogen (ammonia and nitrate). Metals and phosphorus can be sequestered in plant materials and wetland sediments. Because much of the treatment that occurs in wetlands is from microbial, physical, and chemical action rather than plant uptake, these sysferns continte to function during winter. The processes that rely on microbial action, such as nitrogen removal continue but at a slower rate. The processes that rely on physical and chemicar action will continue unaffected by the change in water temperature below the ice surface. If the treated wasteviaker continues to flow through the winter months, the snow and ice cover can proviose an effective temperature buffer that will allow continued treatment.

\section{Subsurface Flow (SSF) Constructed Wetlands}

SSF wettands are gravel or sol-based wetlands in which the wastewater passes through the porous substrate rather than above an impermeable substrate. The large surface area of the media and the plant roots provides ample sites for microbial activity. SSF systems use many of the same emergent plant species as SF systems. When treating an equivalent volume of flow, gravel-based SSF wettands use less acreage than SF constructed wetlands.

SSF wetland systems have an advantage in cooler climates because so much of the treatment occurs below the ground surface. These systems are therefore less affected by cold air temperatures. Also, gravel-based systems may be relatively low in maintenance requirements and are less likely to have odour and mosquito problems than are lagoons. When properly designed, gravel-based wetland systems have high efficiency rates for removing biodegradable organic matter and nitrate-nitrogen from wastewater. 
A consideration that makes the SSF system attractive, especially for small communities and individual residences, is the reduced potential for human contact with partially treated sewage and the related health implications. This is an important consideration especially when there is public access to a treatment facility for wildlife viewing or other related outdoor activities. The use of an SSF system as a pretreatment step followed by an SF system is an option to consider.

Major disadvantages of SSF constructed wetland systems include their tendency for plugging and overall system costs, which can be five times more than an SF system for a certain pollutant mass removal.

Table 4.3 summarizes the North American treatment wetland opeisitiots: performance for systems receiving municipal and industrial wastewater ane \&tormwater. I is important to note that the summary table represents data collected from/exsting systems and anes not refleot design target loadings.

TABLE 4.3

SUMMARY OF NORTH AMERICAN TREATMENT WETLAND OPERA RECEIVING MUNICIPAL AND INDUSTRIAL WASTEWATER AND STOR:142A FER(YADLEC AND KNIGHT, 1996)

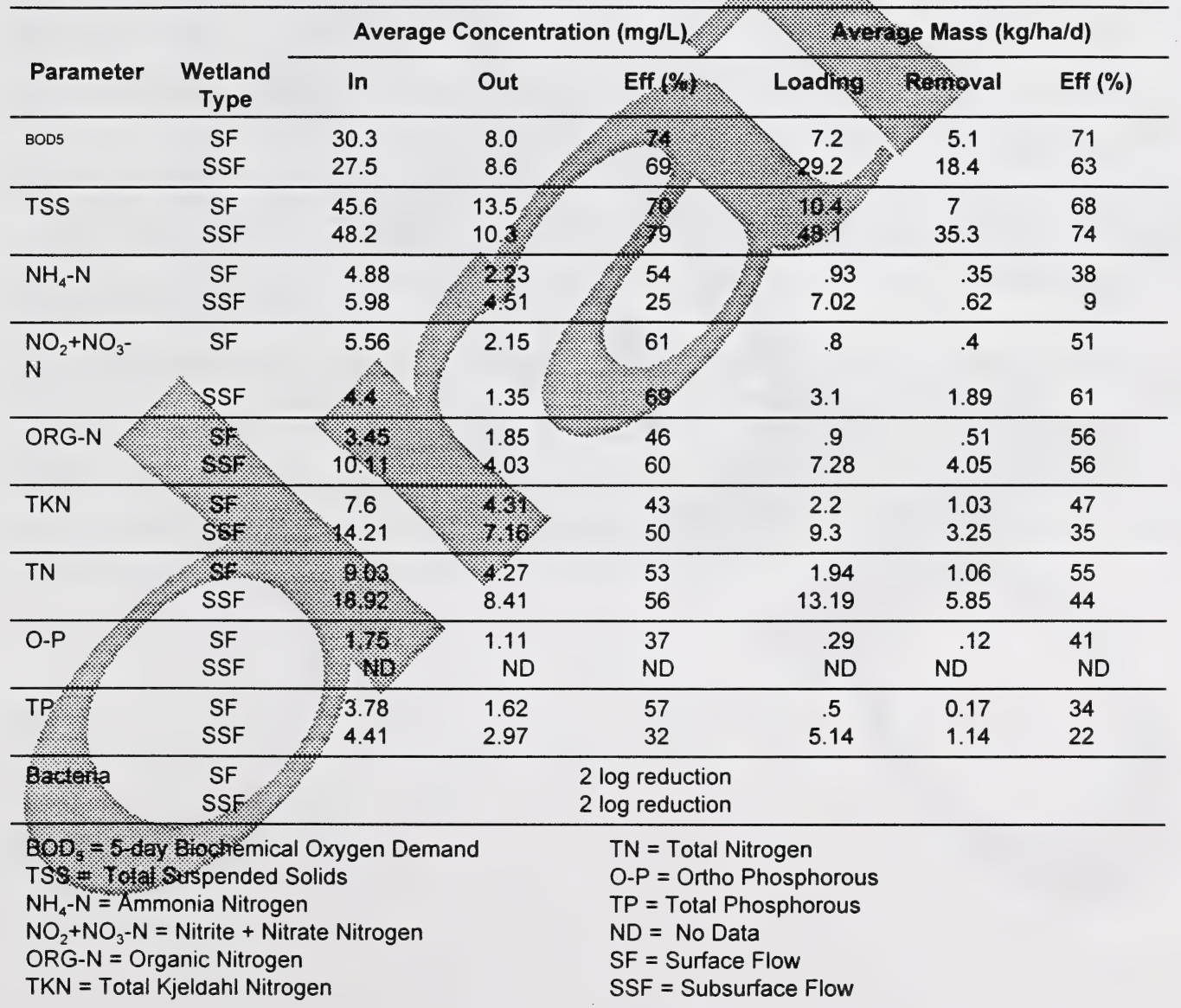

Average livestock treatment wetland concentration performance data for selected parameters is presented in Table 4.4. This data was prepared as part of a report that summarized livestock 
treatment wetlands performance in Canada and the U.S. It was noted during the preparation of the livestock treatment wetlands performance document that the nutrient and solids loading to many of the systems in the database was far in excess of the loadings to the municipal and industrial systems as reported in Table 4.3. Also, many systems were under-designed and therefore produced a relatively poor quality effluent when compared to typical Environment Ministry discharge criteria. However, the overall impact of installing the treatment wetland was the reduction of the contaminant loading to the receiving water. The construction of such a system, even if somewhat undersized, provides sufficient treatment to merit consisferation.

TABLE 4.4

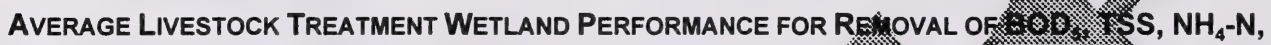
AND TN

(KNight, PAyne, Pries, Borer, Clarke, 1997)

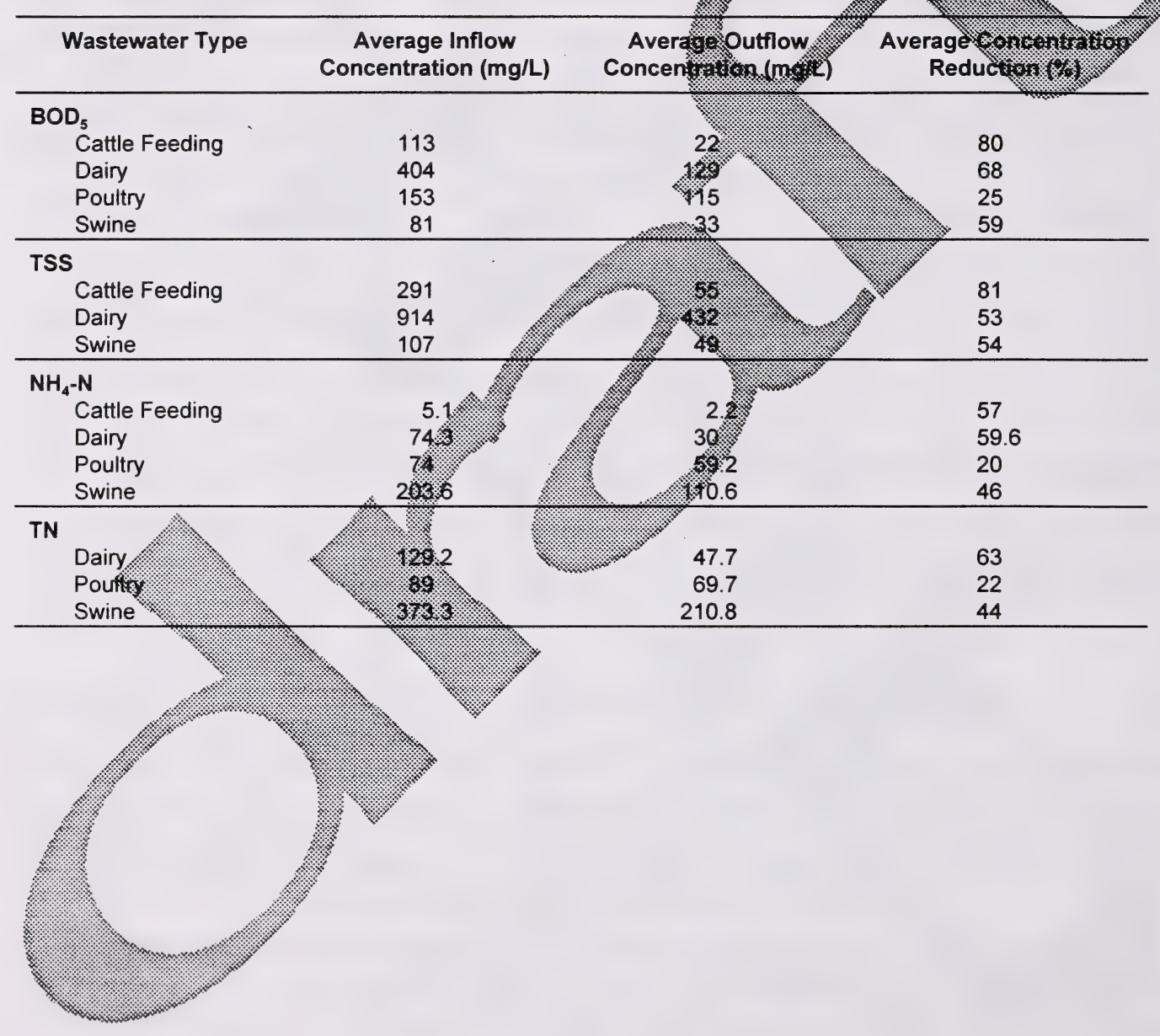




\section{Guidelines for Functions to be Evaluated for Approval of Candidate Site for Treatment Wetland}

Wetlands in Alberta serve functions which benefit the ecosystem and directis ind indirectly, humans (e.g. D.A. Westworth and Associates Ltd., 1993, Usher a. Sc. Water Resources Commission 1993a, 1993b). Natural wetk sites may already serve several important functions, wh which has undergone primary or secondary treatme because twa mutriegls,

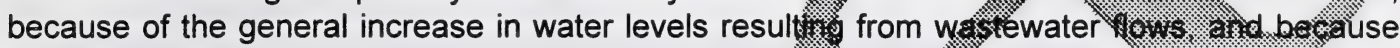
certain areas of the wetland may have to be deepene treatment efficiency.

Table 5.1 lists the issues or functions which should we vorntined when investigating the possibility of using a natural wetland or other natural/ave for. wastewater treatment and is the final summary sheet to be used to summarize all functions examined sturing investigation of the candidate site. Functions summarized in this tatof a a those which have been found to be

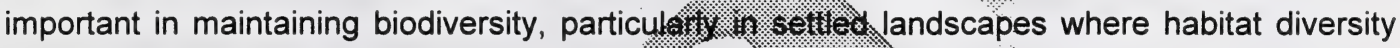
tends to be gradually eroded and biodiversity declines. Checksheets following Table 5.1 should be used to guide inventories, which are resigned reveal indicators of biodiversity, and assist in determining whether use of the candixivate site functions. Appendixes $C$ to I provid: informatisin and references to aid in determining whether indicators found are significant.

The checksheets which make the buts or this section summarize a work program to be

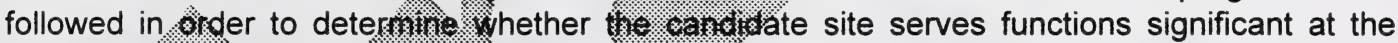

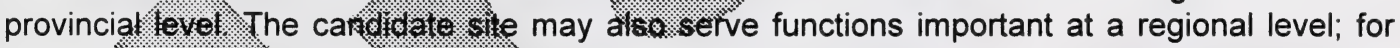
example, He presence of a r.s.

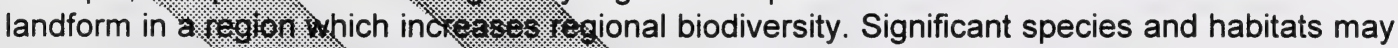

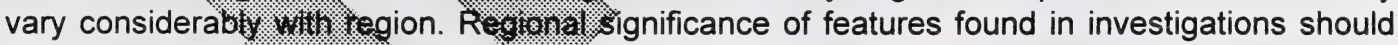
also be examined as gar. of candidate site evaluations.

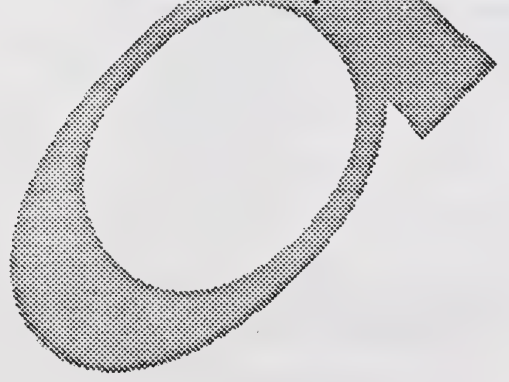


TABLE 5.1

SUMmary SHEet for EVAluation of ECOlogical Functions of a CANDidate Site (CHECK APPROPRIATE BOXES AFTER COMPLETING EVALUATION)

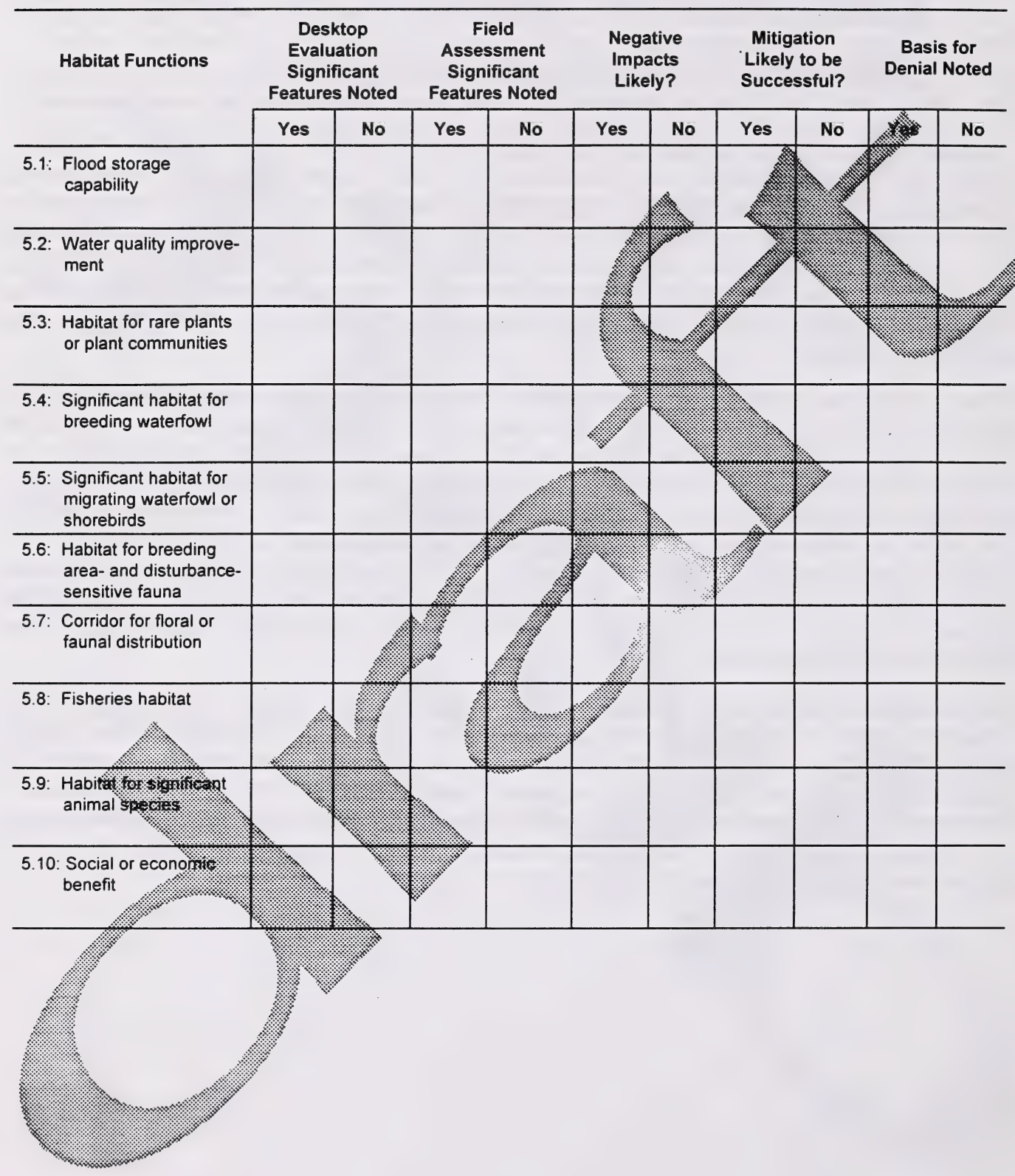




\section{Alberta Department of Environmental Protection Treatment Wetland Evaluation}

\section{1: Function: Flood Storage Capability}

Rationale: Wetlands function in flood and erosion control, water storage, and protection of groundwater recharge and discharge.

\section{Methods for Evaluation}

Office evaluation-document the following

Conduct preliminary calculation to determine the area of the watershed drair.

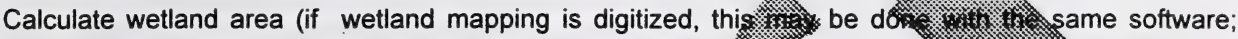
otherwise a polar planimeter may be used ).

Calculate catchment area.

Calculate average monthly rainfall (Reference Environmeris anada 198. (Appendix d)

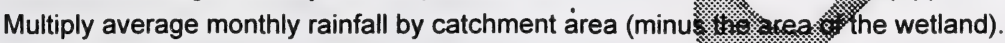

Multiply by an appropriate runoff coefficient.

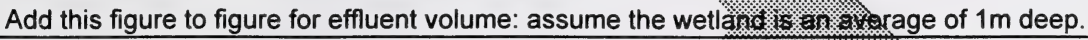

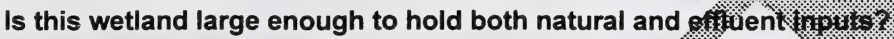

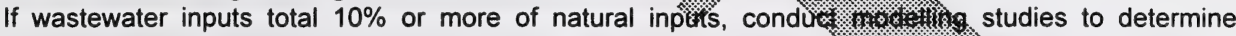

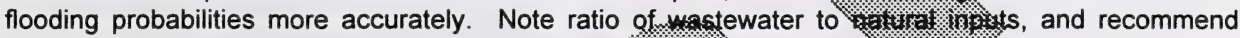
further studies if needed.

\section{Determine probability of flooding ofing a 1 in 36 year evers.}

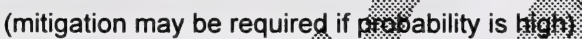

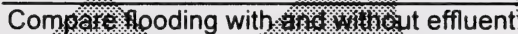

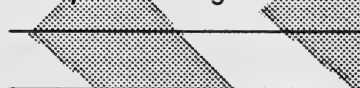

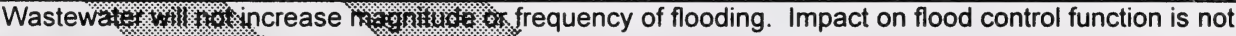

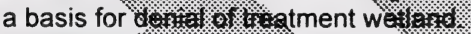

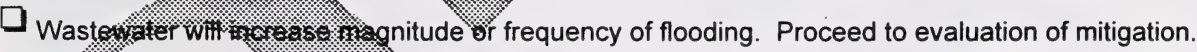

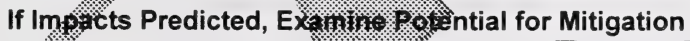

Can a control structure pes e. ected? Yes $\square$ No $\square$

Describe:

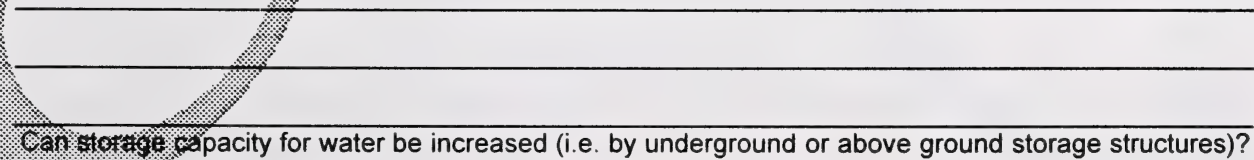
Hole reosnsider possibilities of impacts on other wetland functions as a result of increasing storage.

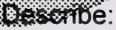


Final Analysis: Predicted Net Impacts and Action Mitigation Potential:

Conclusions:

$\square$ No negative impact likely. Impact on flood control is not a basis for dentrat of treatment wetland.

$\square$ Negative impact likely. Impact on flood control is a bastis. tro. ofopial of treatment wetland.

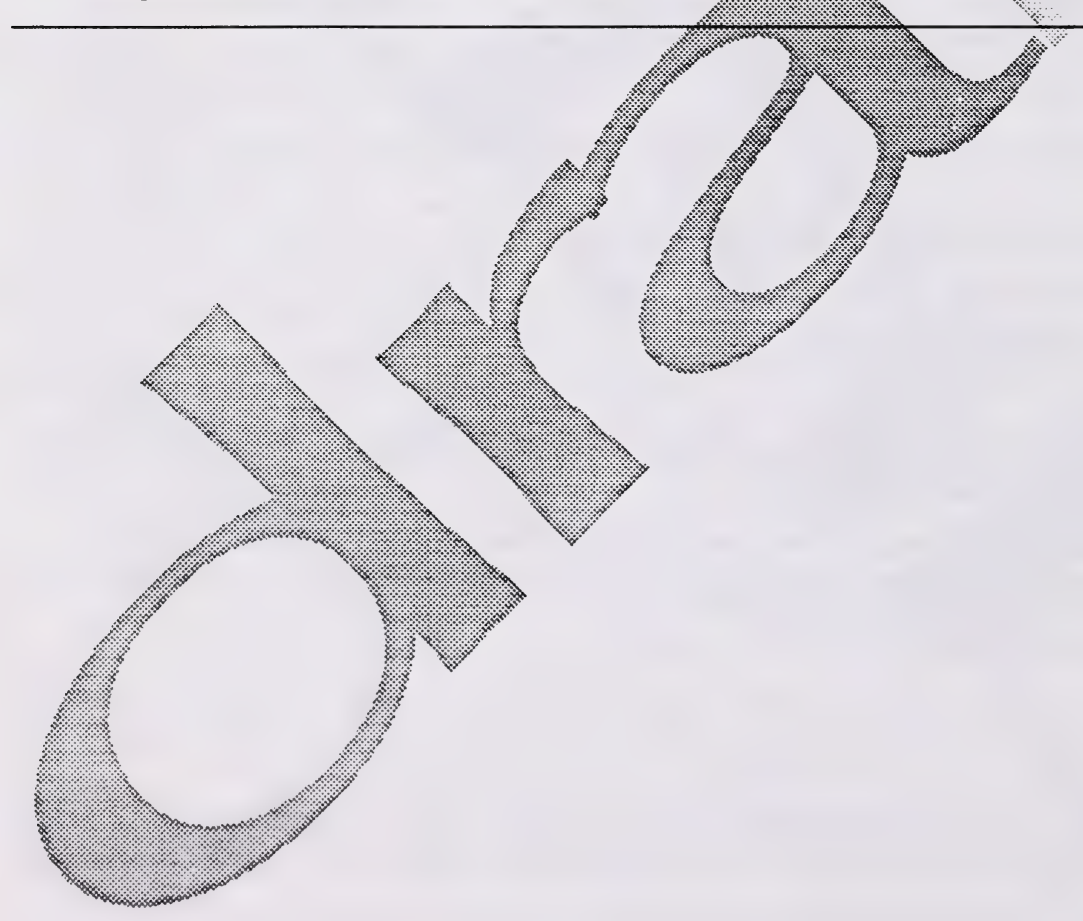




\section{Alberta Department of Environmental Protection Treatment Wetland Evaluation}

\section{2: Function: Water Quality Improvement}

Rationale: Wetlands function to store and transform certain chemical elements which could otherwise affect downstream surface or groundwater quality. Additional inputs from effluent may result in unacceptable water quality downstream.

Increases in water flow can affect this function by reducing the hydraulic retention time in the wetland, (thereby reducing treatment time), and by keeping sediment suspended or resuspending settled material.

Groundwater can become contaminated by recharge from contaminated surfici water.

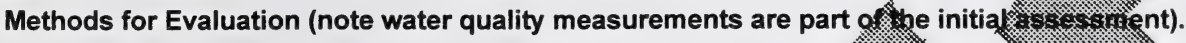

Measure water quality entering and leaving wetland (as repors. preliminan. Table 1 Section 1). Note where measurements taken (map i

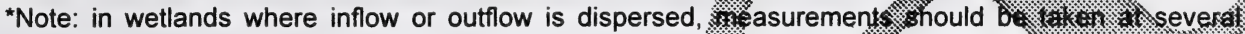
points.

List the following water quality parameters :

$\begin{array}{lll}\text { Phosphorus: } & \text { Inflow__ Outflow } \\ \text { Nitrogen: } & \text { Inflow_ Outflow } \\ \text { Suspended solids: } & \text { Inflow_ Outflow }\end{array}$

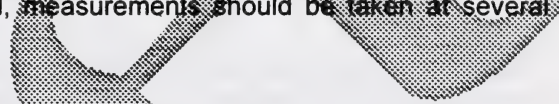

Nitrogen

Suspended solids: Outflow

List other potential contaminating inputs (ie. feedlot onerations, storm, wate both point and non-point sources of contamination)

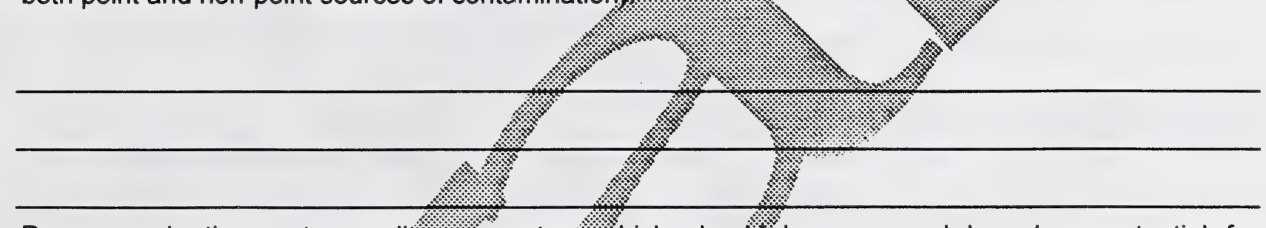

Recommend other water qualits sarameters contamination from surrounding 3 kea.

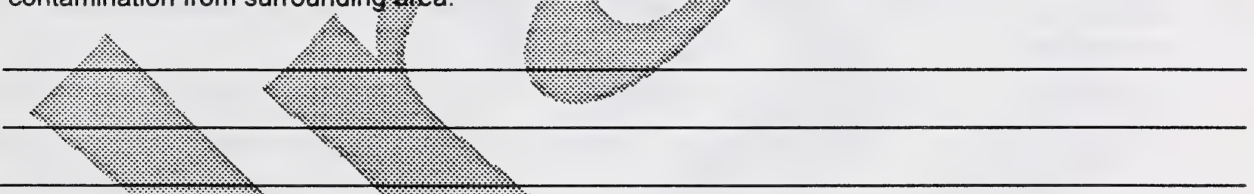

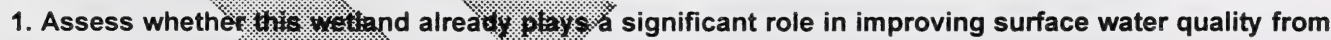
surrounding inpsitus.

Explair.

Wetland does not recêke significant inputs. Negative impacts on this function are not a basis for denial of treatment wetland

Wetland significants 3 ireats water from incoming sources. Proceed to evaluation of impacts.

if wetland cutontly provides significant water quality improvement, determine potential for

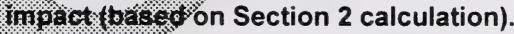

Pedio moracts from increase in hydroperiod:

Predict impacts from increased nutrient loading: 


\section{Assess potential for contamination of the groundwater table through recharge of surface water} Determine soil type from existing soils data or obtain soil core from the wetland:

\section{Estimate:}

Soil permeability

Water balance of wetland

Note whether contaminated water could reach the local aquifer though reck

No negative impact likely. Impact on water quality is not a of

$\square$ Negative impact likely. Proceed to evaluation of mitigation.

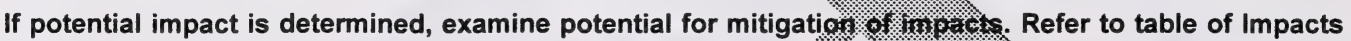
and Mitigation (Appendix D).

Further pretreatment of incoming wastewater:

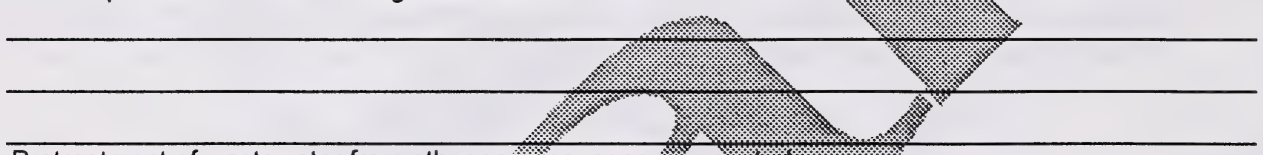

Pretreatment of wastewater from other somines, or sol

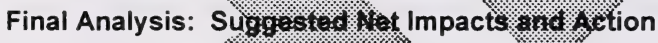

1. o megative impact likely. Impact on water quality is not a basis for denial of treatment wetland.

$\square$ Negative impact likely. Impact on water quality is a basis for denial of treatment wetland. 


\section{Alberta Department of Environmental Protection Treatment Wetland Evaluation}

\section{3: Function: Provision of Habitat for Rare Plants or Plant Communities}

Rationale: Some plant communities, for example, native prairie, have been almost eliminated by development for agriculture, etc. Rare plants and plant communities are often highly sensitive to changes in nutrient and moisture regimes.

"Note: In some areas where soil disturbance and a high proportion of "weeds" is the norm, predominantly native plant assemblages can be considered significant.

\section{Methods for Evaluation}

Office Evaluation

Contact and document correspondence with agencies area (e.g. Department of Environmental Protection, Natural Resou Service; $\ldots$ Museum of Natural History).

Contact and document correspondence with local sources landowners).

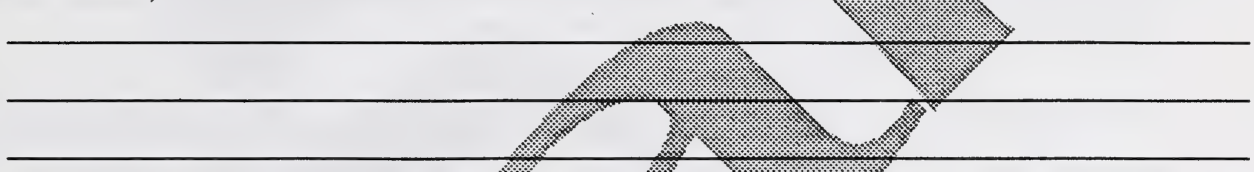

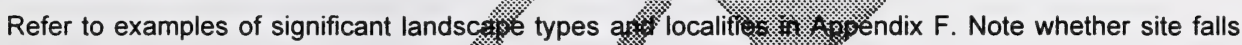
into categories listed as potentially signixicant.

Refer to Packer and Bradley (1984 distribution.

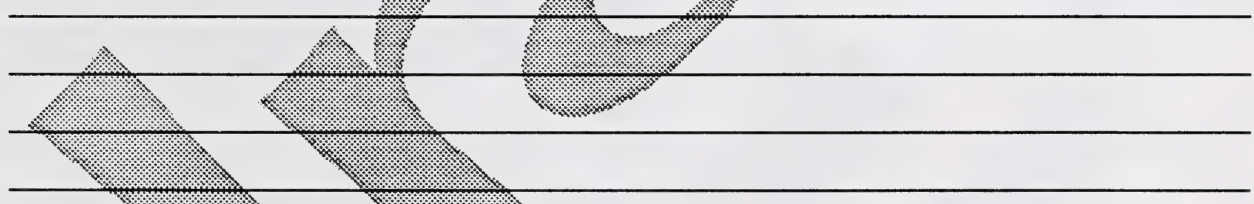

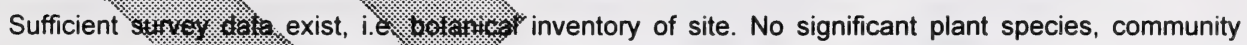

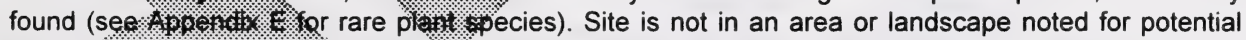

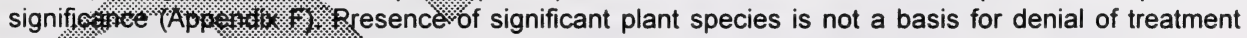
wettind.

D.

Preliminary field evalisitios.must be conducted if no inventory exists, or if the site falls into area or landscape categories

\section{Piseliminary Field Evaluation (to be conducted by a qualified vegetation specialist)}

summarize from .

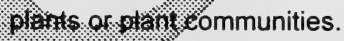


Summarize from field notes indicators of significant plants or plant communities at the site (e.g. certain plant species, soils or landform coupled with absence of disturbance by tilling or intensive grazing; history of fire); or presence of significant plant species in similar habitat nearby).

If such indicators are found, particularly if the site is in an area or landscape ty noted for potentially significant flora (Appendix F), conduct intensive field evaluakizh and sive rationale for conducting full inventory.

\section{Intensive Field Evaluation}

Botanical Inventory (conducted on at least two visits: approxitrits w winciding with summer and fall. Woodlands should be additionally evaluated in spring).

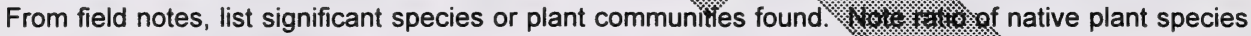
to total species. Append plant community mapping, plant

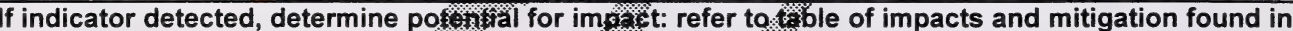
Appendix D.

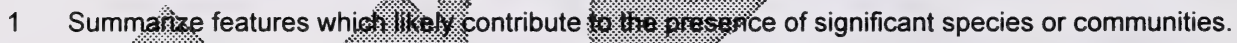

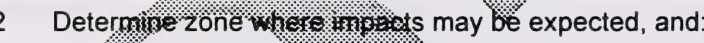

A. Asiess expected imp.s.s. from oncrease in hydroperiod (e.g. potential replacement of extant plant communities by comminaities.
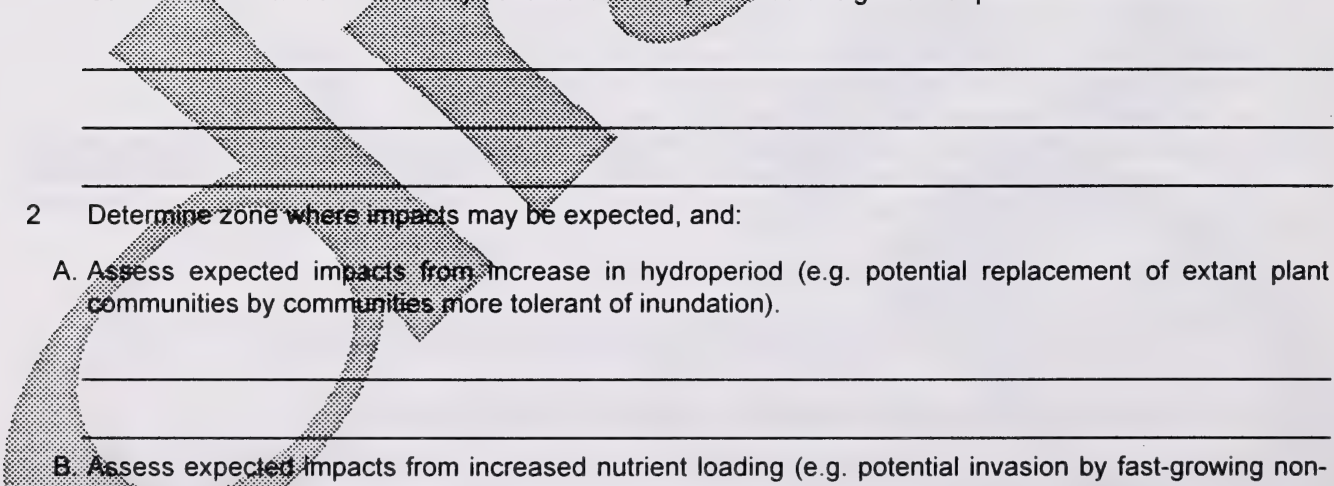

fissess expectevimpacts from increased nutrient loading (e.g. potential invasion by fast-growing nonntativespesiles. Change in vegetation, change in water quality, decrease in species diversity). 
C. Assess expected impacts from earthworks, if proposed.

No impact likely. Impact on significant plant species or communities is not a basis for denial of treatment wetland.

$\square$ Impact likely. Proceed to examination of mitigation.

If potential impact determined, examine the potential for mitigation afforded by $\$$. 3 in $\&$ ing techniques

Restoration of habitat (e.g. planting of native species, etc.):

Further treatment of wastewater:

Pretreatment of wastewater from other sources, of

Final Analysis: Suggested Net Impacts and Action

Mitigation fotential:

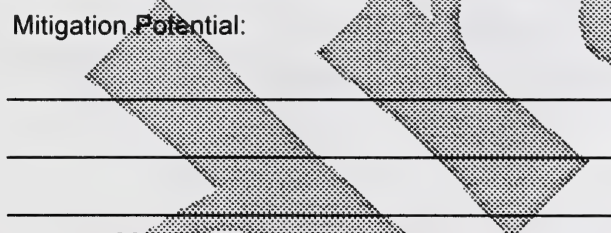

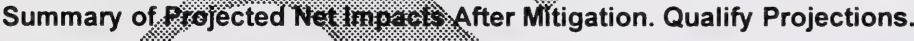

Condisions: are net impocts acceptable? Explain:

No negative impact likely. Impact on significant plant species or communities is not a basis for denial of treatment wetland.

$\square$ Negative impact likely. Impact on significant plant species or communities is a basis for denial of treatment wetland. 


\section{Alberta Environmental Protection Treatment Wetland Evaluation}

\section{4: Function: Significant Habitat for Breeding Waterfowl}

Rationale: Even small wetlands have been shown to be important in waterfowl production, particularly in prairie and parkland ecoregions. Initiatives like the North American Wetland Management Program (NAWMP) recommend protection of potholes.

\section{Methods for Evaluation}

Office Evaluation:

Contact Ducks Unlimited; Department of Environmental Protection Natural ourcervice for preexisting information re: breeding waterfowl. Note whether site is w ubject to . . .

Refer to the following references (Appendix C): Strong o value of wetlands in the Settled Area to waterfowl, Nietfield et al

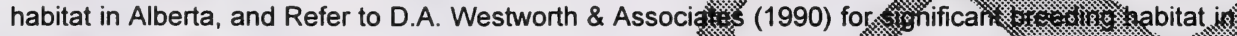
Boreal Forest region

Document known level of significance:

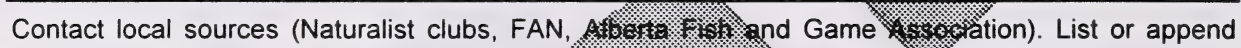

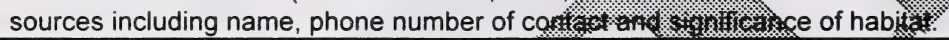

Document level of significance from these sources:

Wetland is not considered signthestit and has peen evaluafed within past 5 years. Significant habitat for breeding waterfowl is not a basis for jutnal of tresikment wetland. If information not available, conduct preliminary field $\mathrm{ks}$ sit.

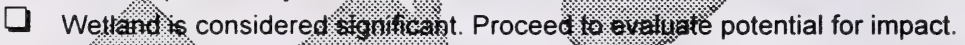

If information is not availabile. wondect preliminary field visit to determine potential significance.

Preliminany, field wiste:

Note following vitraties:

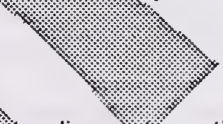

- $50 \mathrm{~m}$ (dianeter) \& . 17010 tranding warer until late summer

$\square$ Concealing vegetation

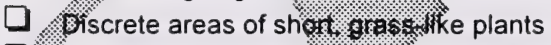

D. Submerged or floatikg actuatic vegetation

1) Shrubby areas

Check if other wetlands with standing water (as above) are within $5 \mathrm{~km}$; linked by natural habitat; linked by agricultural land, i.e. not separated by ecological barrier

If standing yater plus three or more of these conditions apply, a field evaluation must be conducted: note whether field evaluation advised.

\section{Yes. No}

$\square$ Wetland is not considered significant, and preliminary field visit does not indicate potential significance. Habitat for breeding waterfowl is not a basis for denial of treatment wetland.

Wetland is considered significant. Habitat for breeding waterfowl is a basis for denial of treatment wetland. 
Intensive field evaluation (to be conducted by a qualified waterfowl biologist)

Conduct and provide record of one of the following waterfowl surveys:

Conduct observational and nest (dragging) surveys in late April to June.

Conduct surveys of downy young and post-breeding adults in May-July.

\section{Estimate number and species of waterfowl pairs observed}

Assess significance of habitat

As estimated from field surveys:

In consultation with agencies noted above :

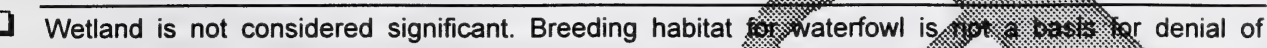
treatment wetland.

Wetland is considered significant. Determine and record tiat.

\section{Determination of Potential for Impact}

1. Assess factors contributing to significance of habitat basti: 0.7 .

- Factors noted above

- High percentage of wetlands in the region

- Large and undisturbed habitat tract

- Other

2. Determine zone where impacts may be expicted, an, 0

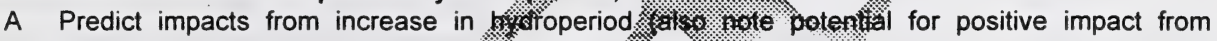
increase in permanence of water, akea of wetlak, etc.) Refer to table of impacts in Appendix D.

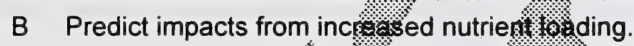

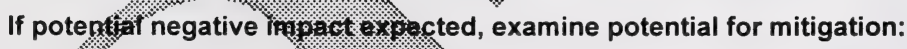

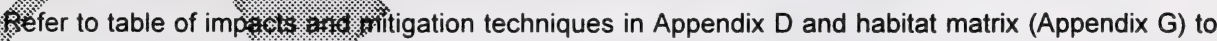
aid in determining imsacks teve to vegetation shifts.

Potential for mitigatios offered by creating habitat.

Potsensuer for mitigation offered by further pretreatment of wastewater.

Assess potential for success of mitigation: 
Summary of net impacts after mitigation:

Final Analysis: Suggested Net Impacts and Action

No negative impact likely. Impact on waterfowl breeding wetland.

$\square$ Negative impact likely. Impact on waterfowl breeding wetland.

Conclusions:

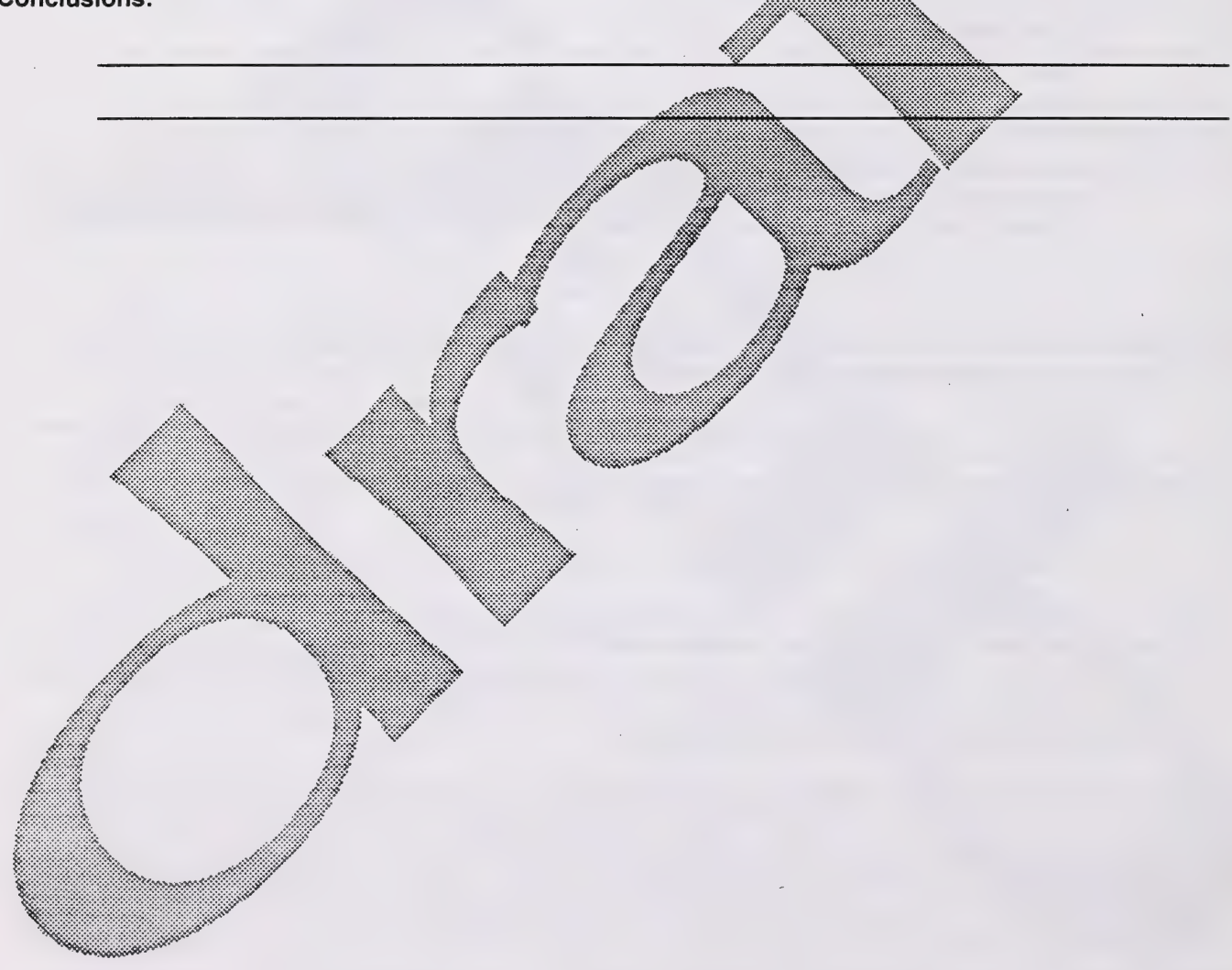




\section{Alberta Department of Environmental Protection Treatment Wetland Evaluation}

\section{5: Function: Significant Habitat for Migrating Waterfowl or Shorebirds}

Rationale: Migrating shorebird and waterfowl populations are vulnerable to human interference, since they concentrate in great numbers in only a few locations along migratory pathways (Dickson and Smith 1991).

\section{Methods for Evaluation}

"Note: Field evaluation of significance of habitat for migrating waterfowl and shorebirds 4 . complex to be beyond the scope of this evaluation. Evaluation of this criterion will be gental and based on existing information only.

\section{Office Evaluation:}

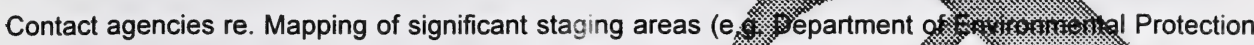

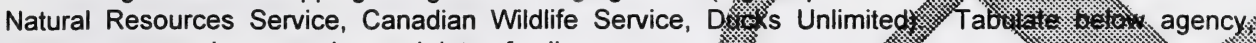
contact person, phone number and date of call.

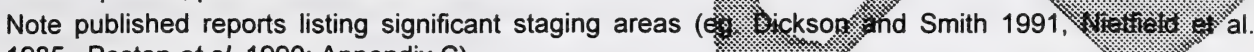
1985, Poston et al. 1990; Appendix C).

* Dickson and Smith (1991) note that Regional Shorebird Sizging. Reserves are those which have at least 20,000 using the site annually or at least $5 \%$ of a species invay population.

No significant shorebird or waterfowl staging area nota staging area is not a basis for denial of treatment wetland.

Significant migratory staging area noted.

If staging area noted, determine potêrutist for impast:

Refer to table of impacts and mitige tion technistises, Appendix.

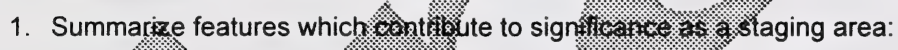

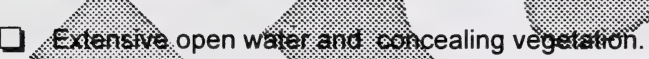

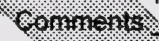

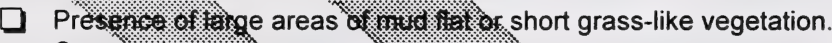

Commentis:

$\square$ Other:

Comments.

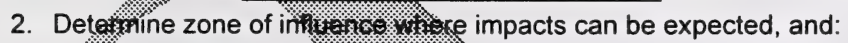

A. Predict impacts from inctease in hydroperiod (e.g. particularly inundation of mud flats, or extension of inundation time vith consequent failure of forage species to germinate and/or loss of invertebrates).

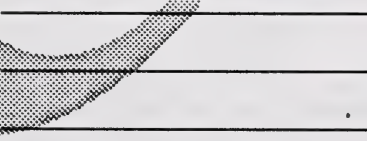

B. Predict impacts from increased nutrient loading (e.g. rapid growth of suboptimal non-native forage species, elimination of some invertebrates). 
C. Predict impacts from earthworks, if proposed:

No negative impact likely. Impact on significant staging area is not a basis for denial of treatment wetland.

$\square$ Negative impact likely. Proceed to evaluation of mitigation.

If potential impact determined, examine potential mitigation of impacts

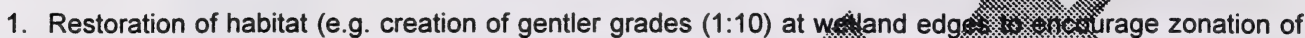
vegetation and development of mud flats).

2. Further pretreatment of wastewater

Final Analysis: Suggested Net Impacts and Mitigatisis:

Mitigation Potential

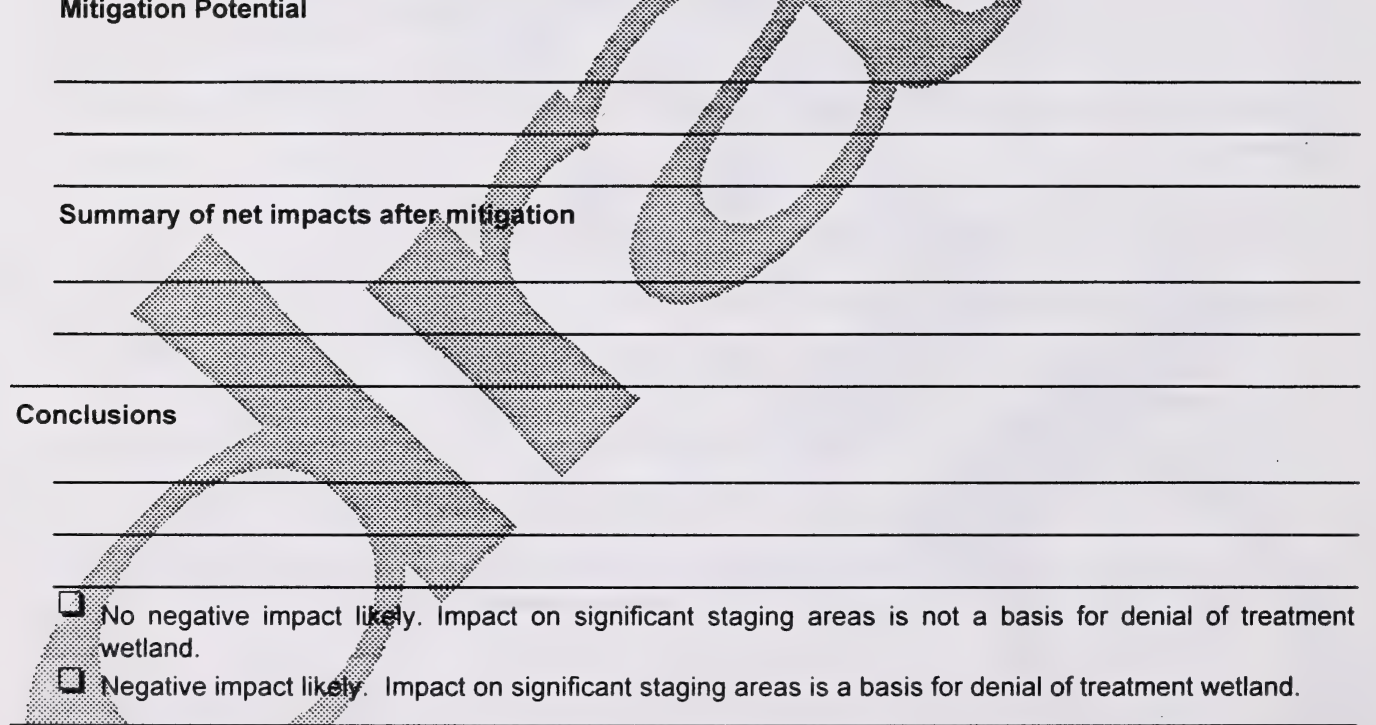




\section{Alberta Department of Environmental Protection Treatment Wetland Evaluation}

\section{6: Function: Habitat for Breeding Area - and Disturbance-Sensitive Fauna (see list of species in Appendix G).}

*Note: This part of the evaluation should be completed only in developed or agricultural areas where habitat is highly fragmented.

Rationale: Some wildlife species appear to require large expanses of habitat (or many connected patches of habitat) at a distance from human development. These species are becoming increasingly rare in settled landscapes.

\section{Office Evaluation}

Contact agencies re. species lists for area (e.g. Alberta Deftment protection

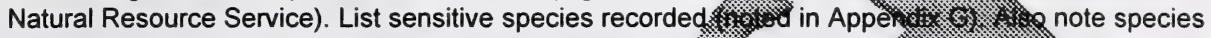
recorded in contiguous or structurally similar habitat withis

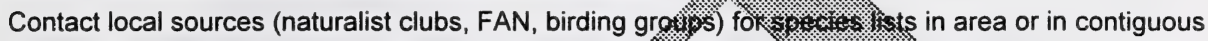
or structurally similar habitat within $1 \mathrm{~km}$. Summarize findings.

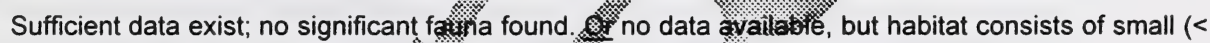
$5 \mathrm{ha})$, isolated patches of naturat. habitat.

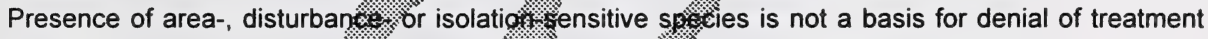
wetland.

Insufficient Data exist.6.

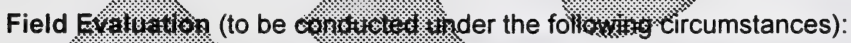

W

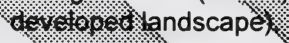

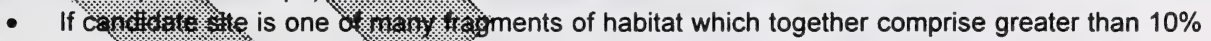

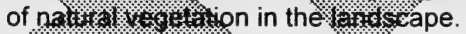

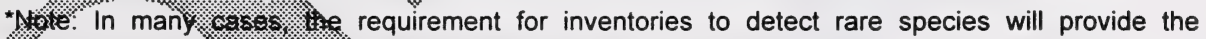

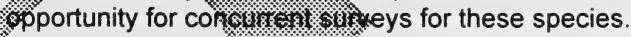

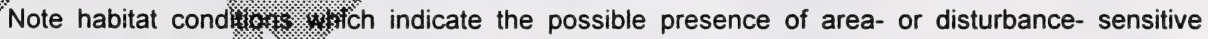
species (e.g. above factiors). 
Sensitive species not found. Presence of sensitive species is not a basis for denial of treatment wetland.

Sensitive species found. Proceed to evaluation of impacts.

If indicator detected, determine potential for impact (refer to Appendix D for summary of impacts and Appendix $\mathrm{G}$ for habitat matrixes which aid in determination of affects of shifts in vegetation):

1. Summarize features which likely contribute to the presence of sensitive species.

- Large and undisturbed habitat tract:

- High percentage of habitat cover in the region:

- Other:

2. Determine zone where impacts may be expected, and:

A. Predict impacts from increase in hydroperiod (e.g. reg. tolerant species; see Appendix D for summary of impow

B. Predict impacts from increased nutrient loading (re.g. chang/ quality, decrease in plant species diversity):

C. Predict impacts from earthworks 聯 proposeo

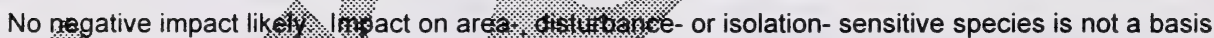

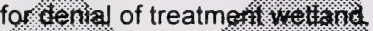

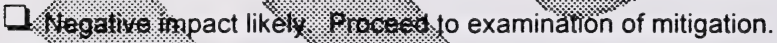

If potenth impad determiner. examine potential mitigation of impacts; e.g. by creation of corridors to other gituitable hatwitat, restóration of habitat outside area affected by creation of

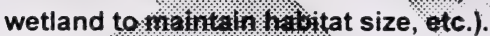

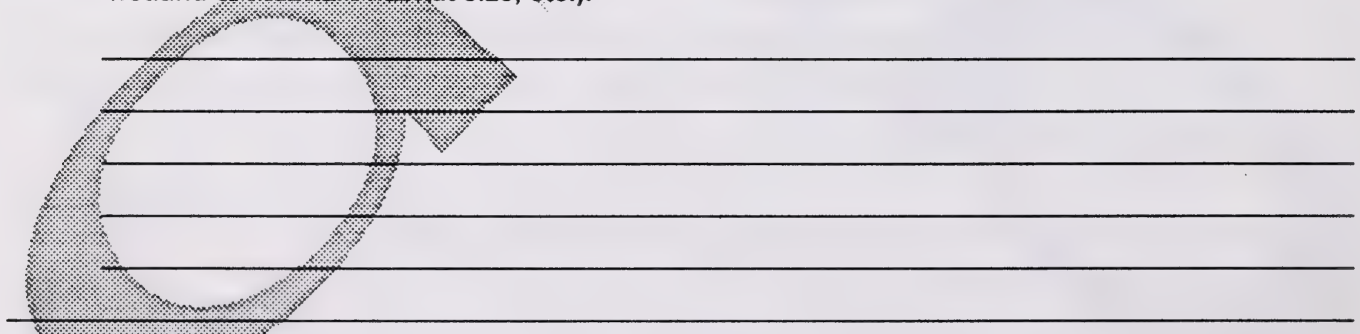

Final Analysis. stiggested Net Impacts and Action

Mitigation Potential: 
Summary of Net Impacts after Mitigation:

\section{Conclusions:}

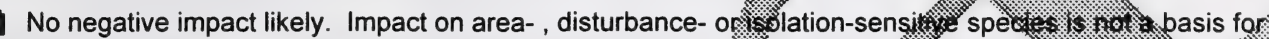
denial of treatment wetland.

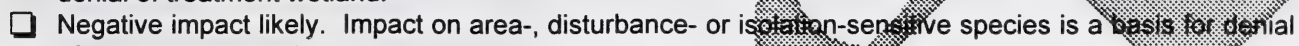
of treatment wetland:

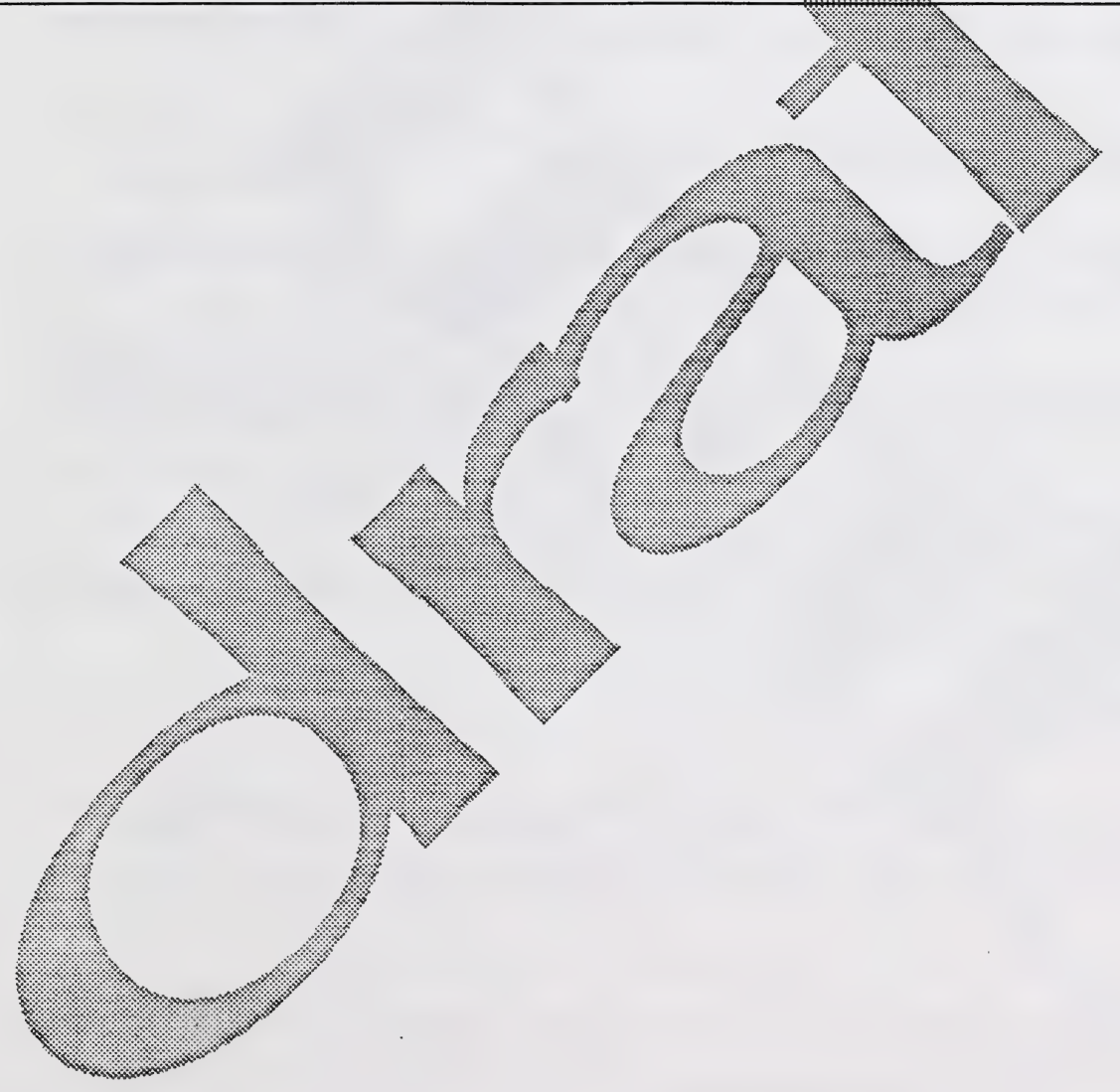




\section{Alberta Department of Environmental Protection Treatment Wetland Evaluation}

\section{7: Function: Provision of Significant Habitat for Floral or Faunal Distribution and Persistence Within the Landscape}

Rationale: Wetlands and other natural areas being considered as candidate sites may be linked to other patches of habitat. Without the pattern of nodes and linkages, habitat becomes fragmented and generally supports lower biodiversity.

\section{Methods for Evaluation}

\section{Office Evaluation}

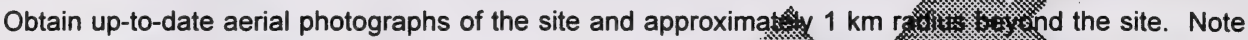

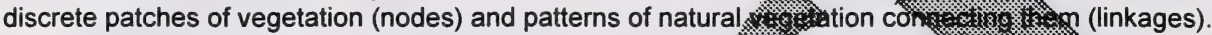

Note and record whether candidate site forms a node or $p$

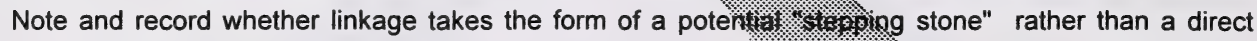
connection.

Note predominant land use surrounding nodes and link

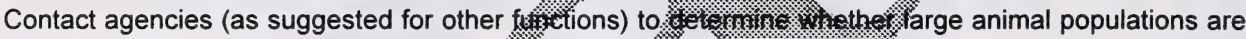

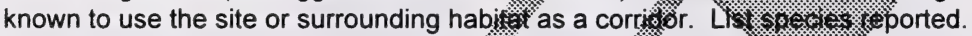

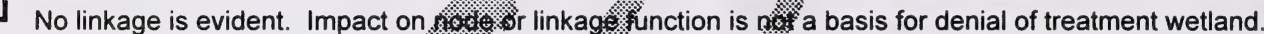

$\square$ Linkage is evident; or large anizriz populations use the ara as a corridor. Proceed to evaluation of impacts.

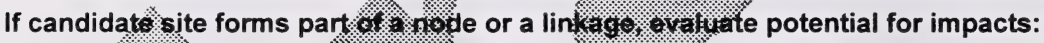

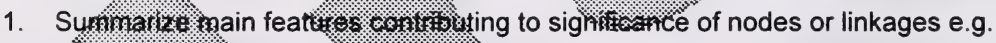

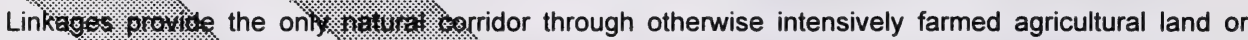

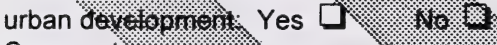

Comment:

Site contributes to natisal andscape significant for size, configuration, links: Yes Comment:

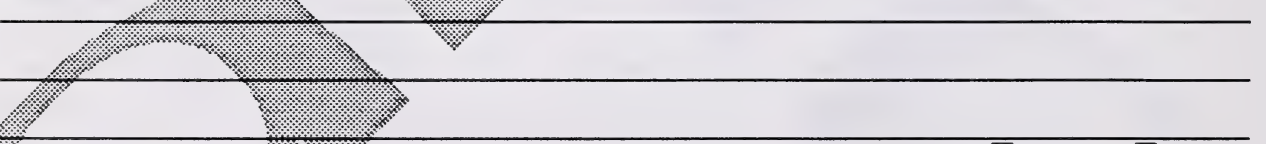

a

Ifvartale:zrne of influence, and:

A. Predict impacts from increase in hydroperiod: 
B. Predict impacts from increased nutrient loading:

C. Assess expected impacts from earthworks, if proposed:

No negative impact likely. Impact on node or linkage is not a bas for denist of ty te thent wetland.

$\square$ Negative impact likely. Proceed to evaluation of potential for

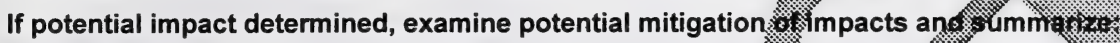

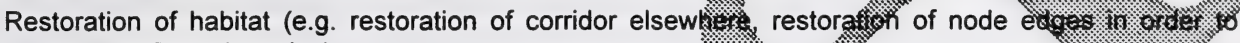
improve configuration, size):

Mitigation Potential:

Final Analysis: Suggested Net Impacts and /4iction

Summary of Net Impacts after Mitigatiter.

Conclusions:

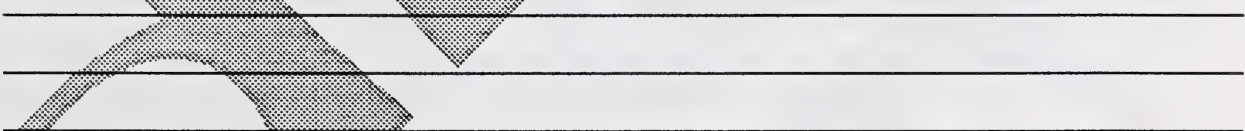

$\square$ Ko negative impact lik wetland.

1: Negative impact likely: impact on significant node or linkage is a basis for denial of treatment wetland. 


\section{Alberta Department of Environmental Protection Treatment Wetland Evaluation}

\section{8: Function: Provision of Habitat for Fish}

Rationale: Though treatment wetlands will not be permitted to affect major fish habitats such as lakes, rivers and streams, pools in some wetlands can provide habitat for some small fish species. Proposals to alter fish habitat are subject to the federal Fisheries Act.

\section{Methods for Evaluation}

\section{Office Evaluation}

Contact agencies such as the Alberta Department of Environmental Protan N Resources Service for existing survey data on the candidate site and hydrological/.

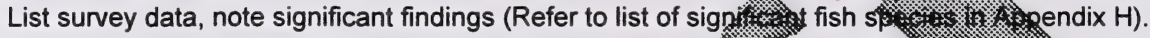

Contact local fishermen (through angling groups, etc.). Liss.; t. of contact. Note findings.

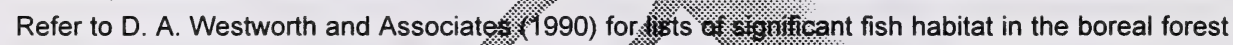
region.

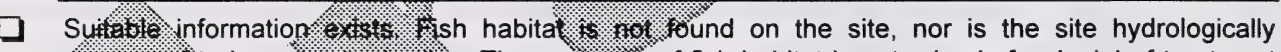

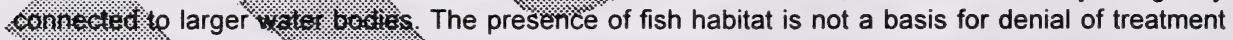
weitong:

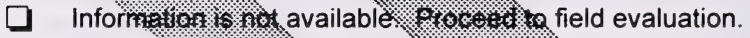

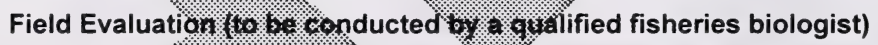

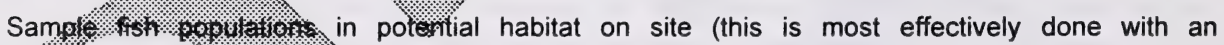
electroshocker). tis numbers and species of fish seen.

Determine if 19 e candidate site contains the following habitat variables:

1. Sulace water connection with larger water body containing fish.

2. Areas of emergent vegetation adjacent to larger water body subject to flooding in spring.

Fish are present in the wetland, or habitat variables apply. Proceed to evaluation of impacts.

Fish are not present, or habitat isolated from larger water bodies containing fish. Negative impact on fish habitat is not a basis for denial of treatment wetland. 


\section{Evaluation of Impacts}

Refer to table of impacts and mitigation, Appendix $D$, and habitat matrix to aid in determination of impacts due to vegetation shifts, Appendix G).

1 Assess factors contributing to presence of fish in water bodies on candidate site (noting whether the population in these water bodies is likely killed off in some years and some seasons but maintained by colonization by fish from adjacent habitat).

2 Determine zone where impacts may be expected and:

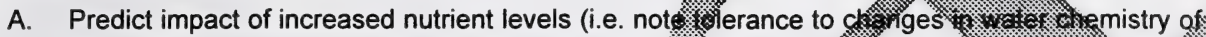
fish species present: also consider tolerance of pres ixtems):

B. Predict impact of increased hydroperiod (i.e. potential introduction predatory species, increased flow rates through habitat):

C. Predict impacts of earthwoisus. proposti:

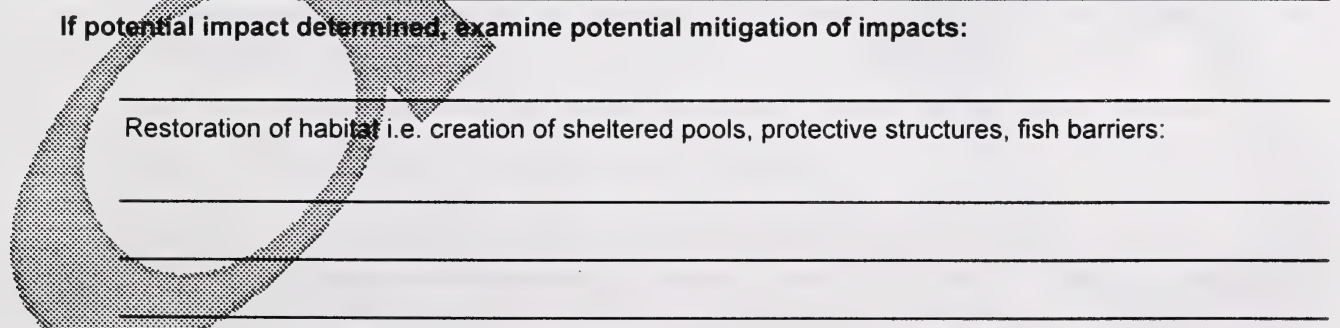

of 
Final analysis: suggested net impacts and action

Mitigation potential:
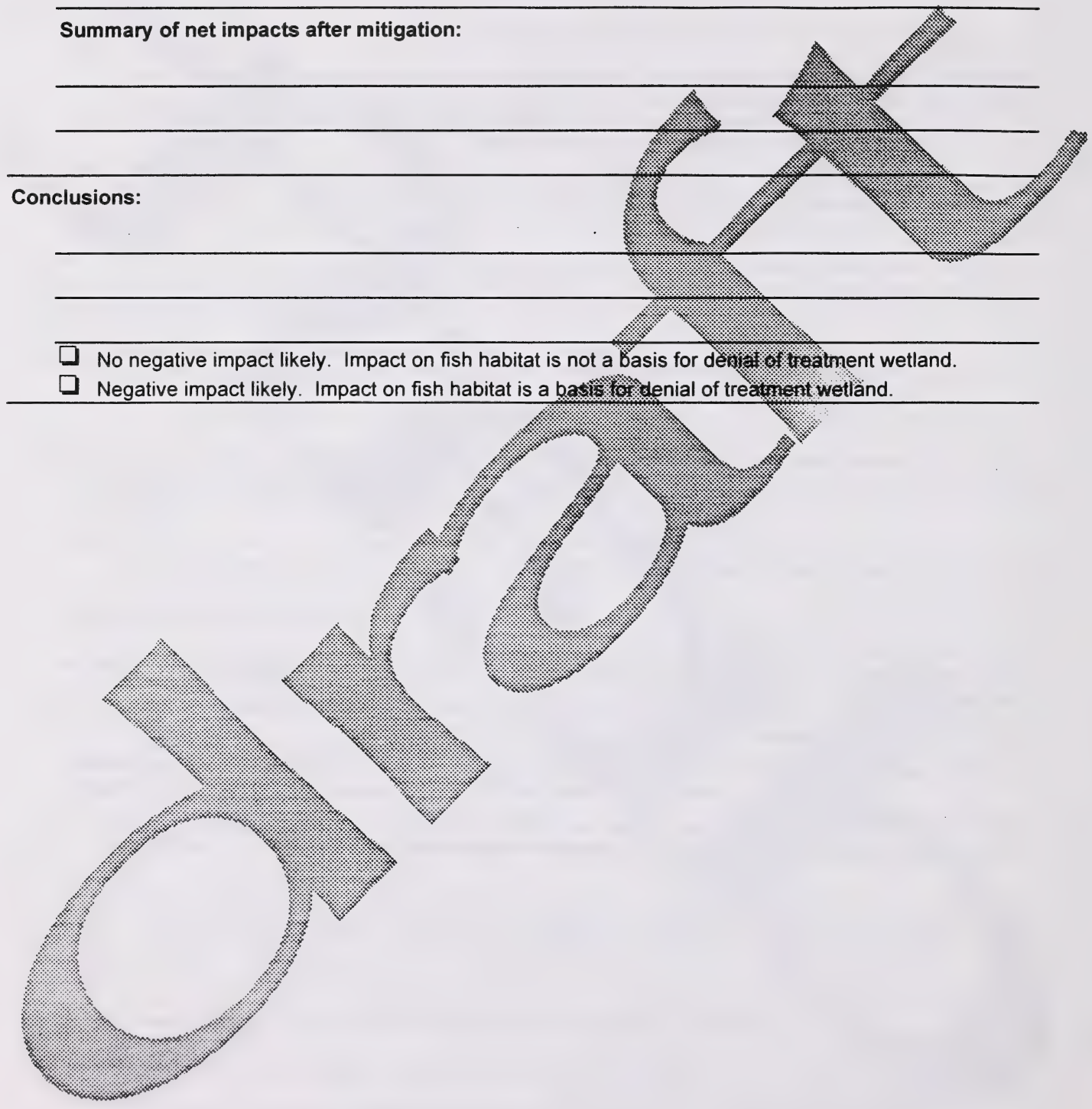


\section{Alberta Department of Environmental Protection Treatment Wetland Evaluation}

\section{9: Function: Habitat for Significant Animal Species}

Rationale: Wetlands provide breeding and foraging habitat for a large proportion of the province's significant species; particularly in grassland regions.

\section{Methods for Evaluation}

\section{Office Evaluation}

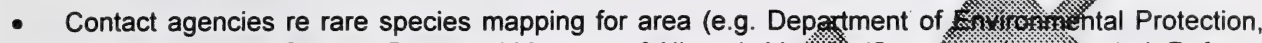

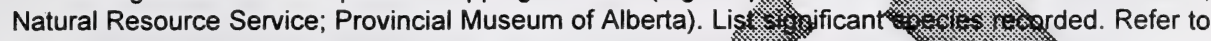
lists of significant animal species, Appendix $\mathrm{H}$.

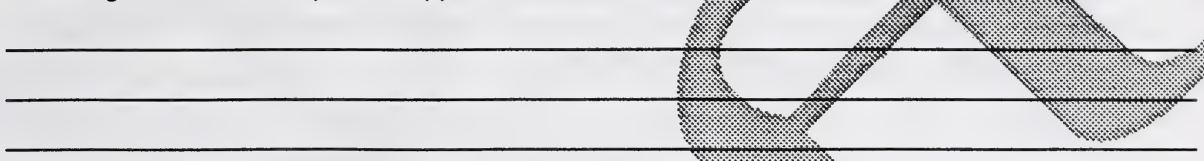

- Contact local sources (local naturalist clubs, FAN, birding ojout. phone number of contact, and significant species sighted/Referts. is s s or significant animal species, Appendix $\mathrm{H}$.

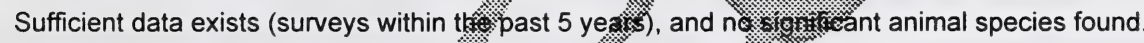
Presence of significant species is nit.

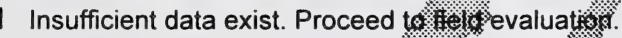

Field Evaluation (scoped to reflect effor required os ofermincos of questions answered in the office) to be conducted by a qualified wildlife thongs

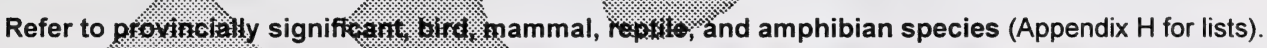

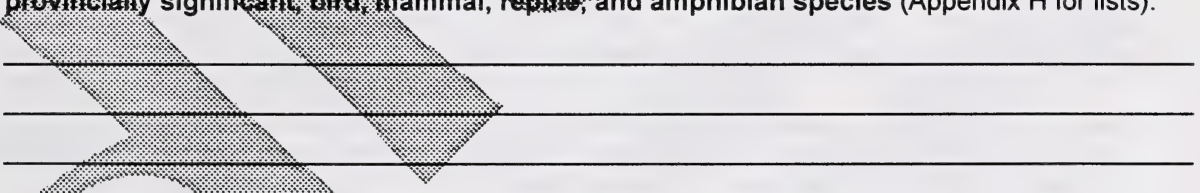

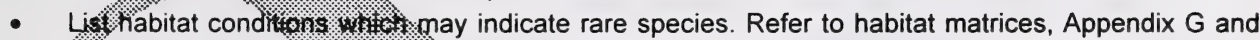
Habitat notes in Appstidtu

1. Conduct breseting bird surveys (generally from last week in May to first week in July, but certain

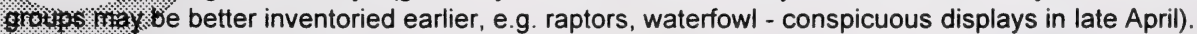
Marny species can be detected by song and call identification, so there is a high return in detecting a targe diversity of species with least effort. List significant findings from field notes. Append complete species list. 
- Conduct scoped breeding amphibian and reptile surveys (surveys of frogs in late evening through April to July bring high return because frogs can be discerned by call; surveys of amphibian eggs or larvae are time-consuming and require uncommon expertise; generally searches under debris can be conducted during other surveys, but bring low return for effort). List significant species from field notes. Append complete species list.

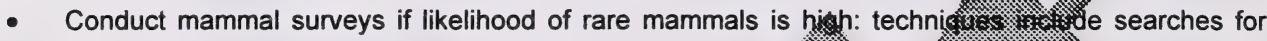
mammal signs (generally reveals only a few common specie. nammat. be used only if strong indications rare mammals may be present and this

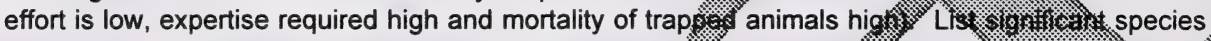
from field notes. Append complete species list.

No significant species detected. Significant animal species is not a tas. wetland.

$\square$ Significant species detected. Proceed to evaluatiogr. of in

If indicator detected, determine potential for impact:

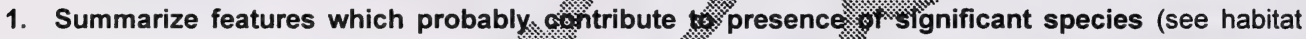
matrices, Appendix G; habitat notes, As:-20 dix H):

- large and undisturbed habitat brat.

- $\quad$ specific vegetation type:

- other:

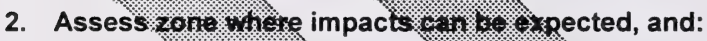

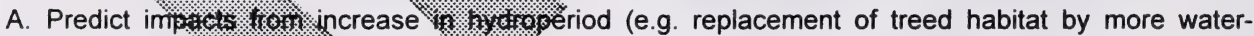

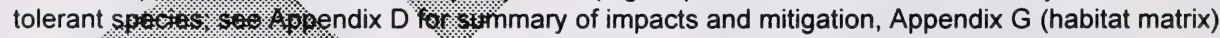

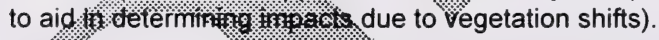

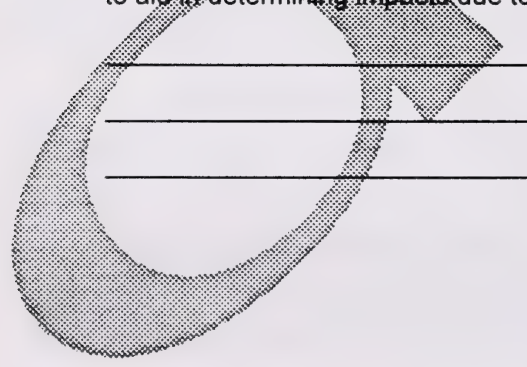


B. Predict impacts from increased nutrient loading (e.g. potential invasion by fast-growing exotic species, change in vegetation, change in water quality, decrease is species diversity).

C. Predict impact from earthworks, if proposed.

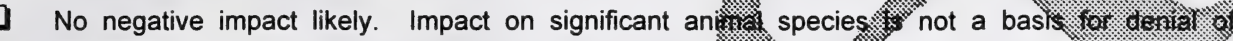
treatment wetland.

$\square \quad$ Negative impact likely. Proceed to examination of mitigatisu.

If potential impact determined, examine potential mitigation of impacts:

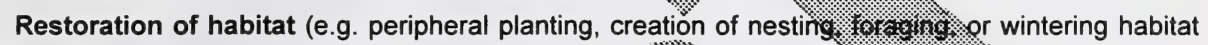
structures):

Further pretreatment of incoming wastivis
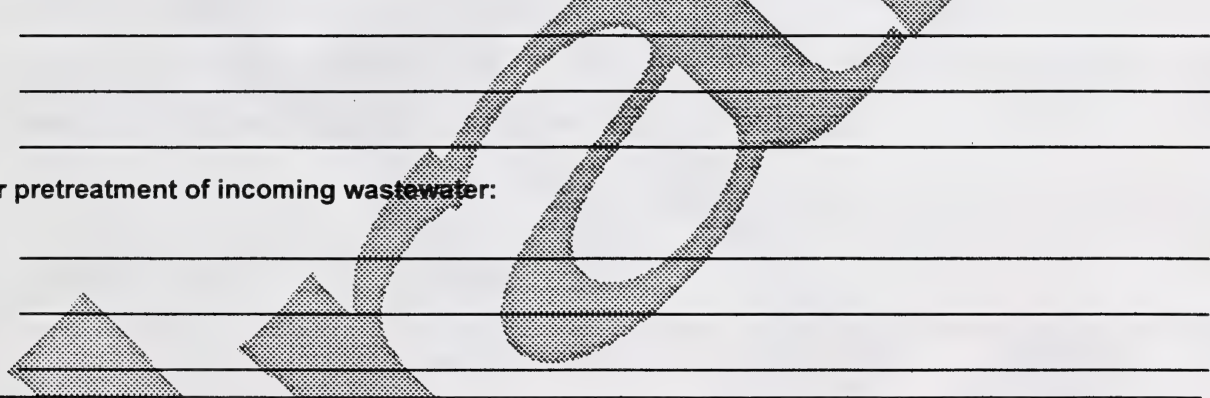

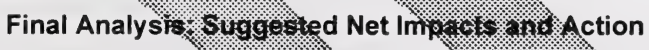

Mitigation Polsontiz:

\section{Summary of Net Impasis After Mitigation:}




\section{Conclusions:}

$\square \quad$ No negative impact likely. Impact on significant animal species is not a basis for denial of treatment wetland.

$\square$ Negative impact likely. Impact on significant animal species is a basis for denial of weatment wetland.

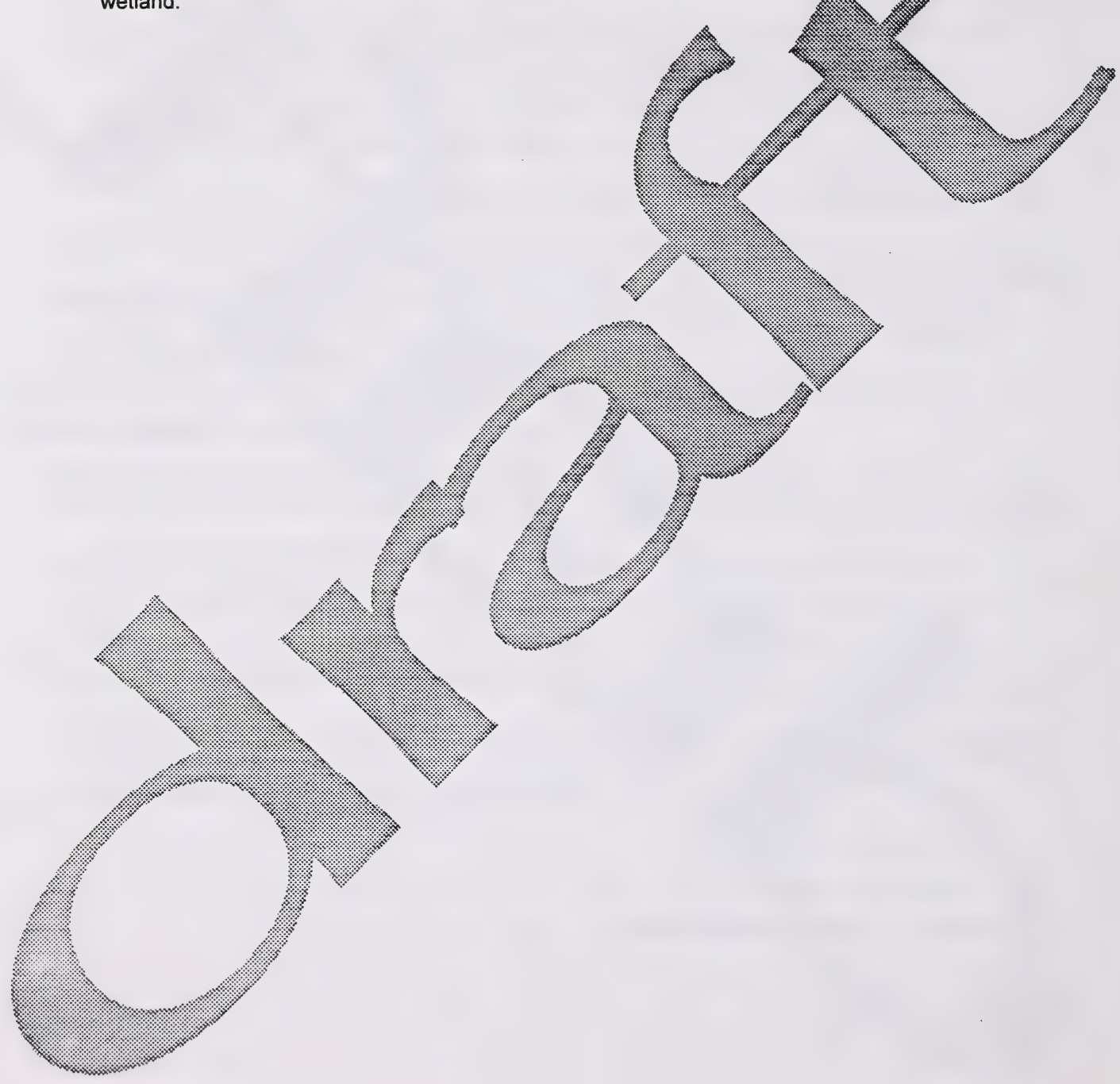


Alberta Department of Environmental Protection Treatment wetland evaluation

\subsection{0: Function: Provision of Significant Human Economic or Social Benefits}

Rationale: Humans derive social and economic benefits from natural areas such as passive and active recreation, derivation of marketable goods and agricultural use.

\section{Methods for Evaluation}

Office Evaluation

Contact the following potential users to determine passive recreational use: schools aturalist clubs, trail clubs, etc. List sources including names, phone numbers.

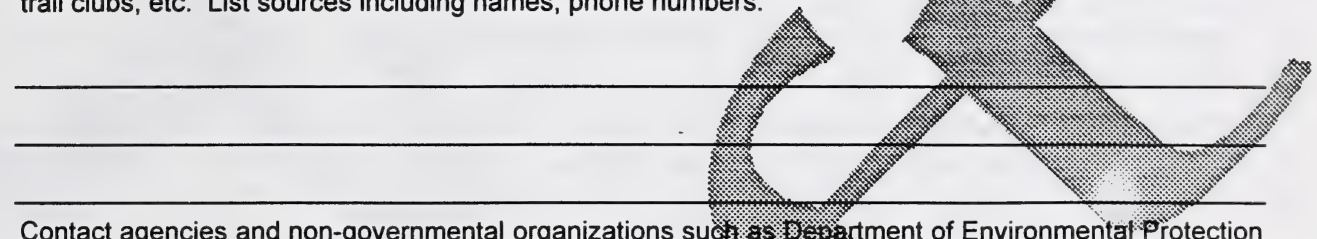

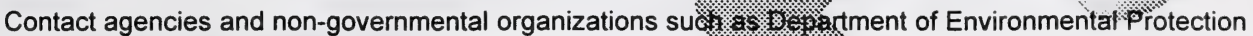

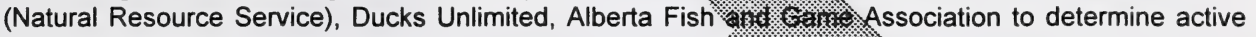
recreational use; document as above.

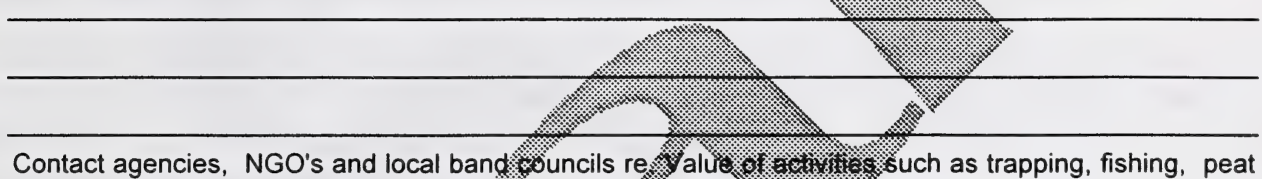
extraction, wild rice harvest, livestock us: haying, fostestry.

\section{No information available: condiu, prelimina iv titeld visit:}

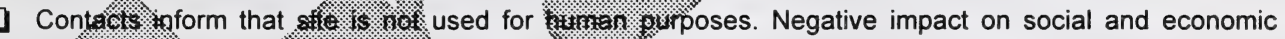

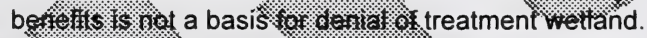

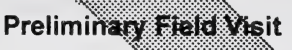

Note the followito win the field:

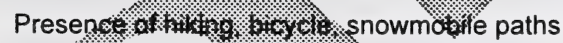

Shotgin shells

Signage

1. Wild Rice (harvest to o detormined from contact with above sources)

Signs of peat extraction

13razing, trampling by ivestock; haying

Forestry

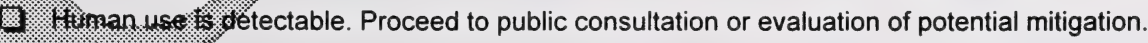

No wimingeve is detectable. Proceed to public consultation (Option 1). 
Option 1: Preliminary (optional) public consultation

If the site is used to treat sewage, it will become inaccessible to the public.

Conduct preliminary Public Information Centre or distribute information to inform potential users of benefits and impacts of using site for constructed wetland. Obtain public comment. Append summarized responses.

*Note: The most important impact of using the site for a treatment wetland is that it will no longer be accessible for public use: evaluation of other impacts is not necessary.

Public concerns not resolved. Proceed to evaluation of potential mitigation

- Public concerns resolved. Negative impact on social and/or economic benefiss is not a is for denial of treatment wetland

Option 2: Proceed directly to evaluation of potential mitigation.

\section{Mitigation of Potential Impacts}

Refer to table of impacts and mitigation, Appendix D.

1. Determine zone where impacts can be expected, and:

Assess potential for relocation of passive recreation
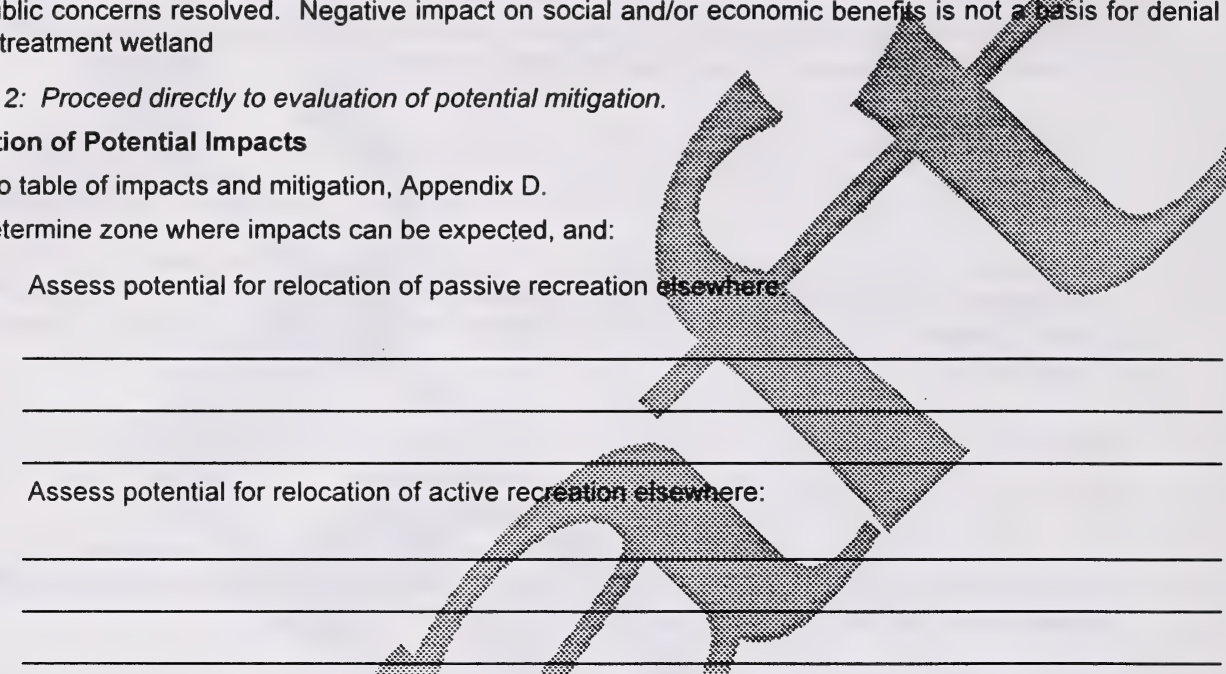

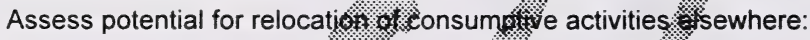

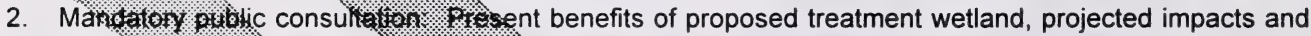

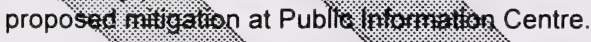

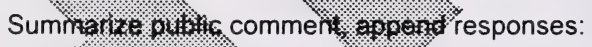

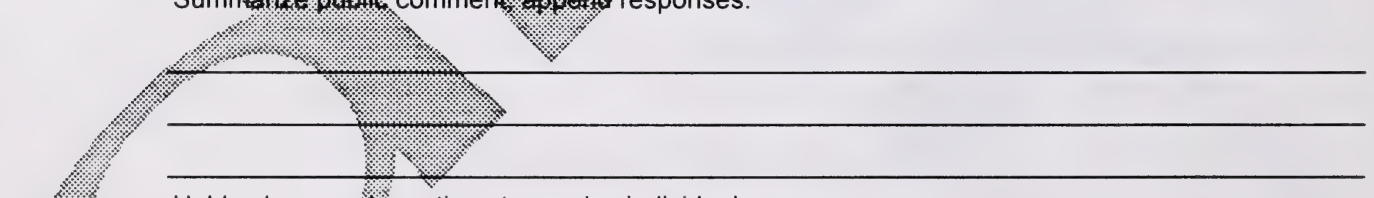

Hold subsequegite meetings to resolve individual concerns

Summarize coiniments and responses:

Public concerns can be resolved. Negative impacts on human social and economic benefits is not a basis for denial of treatment wetland.

- Public concerns cannot be resolved because negative impacts on social and economic benefits of site are likely. Negative impacts on human social and economic benefits of site is a basis for denial of treatment wetland 


\section{Design}

Upon completion of the first three stages, if indications are that the chosen site is appropriate for use as a treatment wetland, then the preliminary design will begin. The requirements for the constructed and the natural treatment wetlands begin to diverge at this point. Each is presented in the following sections.

It is important to note that at the design stage, it is critical to have avaltable aress to recently

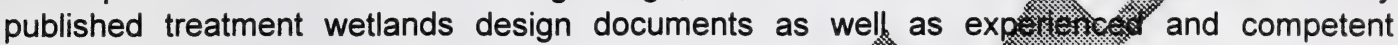
treatment wetlands designers who are up-to-date on the mosecen level

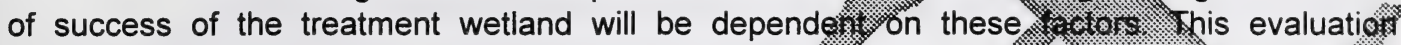

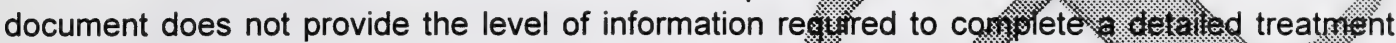
wetland design. However, a listing of the critical cemponents provided and appropriate design documents are referstreed. guidelines is presented in Appendix $\mathrm{J}$.

\section{Constructed Treatment Wetlands Design}

It is anticipated that the constructed treatment wf

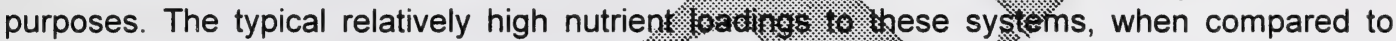

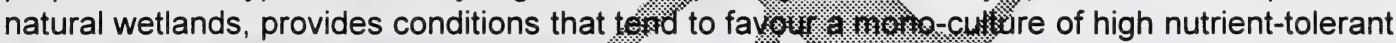
emergent plant species such as cattail.

The design guidance provided in the situdelines approaches to design are found ix s opendix. guidance required to carry the progect to a firitaldesign staige.

One alternative approach is io or ovide a workstop to present an overview on the treatment

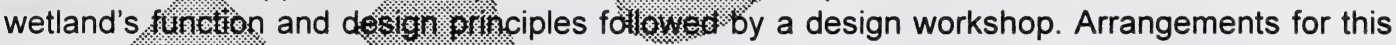

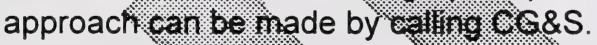

\section{Natural Treatment Wetlands Design}

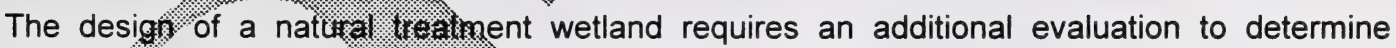
whether the existing wetwas. I. . remain relatively unchanged or if reduction in the diversity of flora and fauna will have a severe negative impact on the wildlife community or generate public opposition. The natural wetlands may be well suited to being divided into a series of wetland cells. The cells closest 10 the wastewater source will receive the highest loading and maintain the lowest plant diversity whereas the wetland cells further downstream will be able to maintain a greater plant and Wild life diversity. The design guidance provided in Appendix $\mathrm{J}$ is of a general nature win reference to treatment wetlands documents for details. These documents are referenced al the end of Appendix J.

\section{Treatment Wetlands: Design Considerations}

General considerations for the design of a treatment wetland are summarized below. It is important to note that these are intended to provide the wetland designer with a very basic 
overview of a typical treatment wetland design. However, each system is site-specific and the assistance of an experienced treatment wetland designer or careful review of a treatment wetland design manual such as 'Treatment Wetlands' (Kadlec and Knight, 1996) is critical to the success of a treatment wetland project.

General design considerations are as follows:

- Design and implement with designated objectives constantly and clearly in mind

- Pretreatment of the wastewater, to at least primary and greferaty to secondary quality with emphasis on suspended solids removal

- $\quad$ Soils should be suited to support wetland yeserâtion

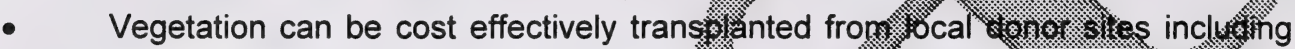
ditches maintained by the Department of : Uighways and constitselisi sites where small pocket wetlands are to be removei

- $\quad$ Freezing conditions during the winter mon 1 is: will not adversely affect the wetland community (plants, microbes) but irearnert efficiency of parameters that rely on bacterial action for concentration reduction wil se reduced

- Design more for function than for forn A number of tom t. can probably meet the objectives, and the form to wilioh the system evolves may not be the planned one.

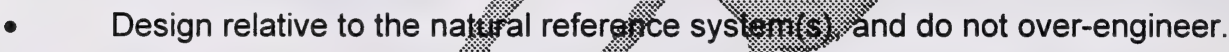

- Design with the landsisa e, not against it. Take advantage of natural topography, drainage patterns, ele.

- Design the wetlaind as an ecotine incorporate as much "edge" as possible, and design in corturnotion with a bufizer and the surrounding land and aquatic systems.

Destgr to protes the wettand from any potential high flows and sediment loads

Plan on anough time tor the system to develop before it must satisfy the objeotives. Attempts to short-circuit ecological processes by over-management will probaby tail.

Design for sel/s sustainability and to minimize maintenance

Constiderations for the size and configuration of the wetland are:

- Active treatment depth is 0.1 to $0.6 \mathrm{~m}$ with an average permanent wetland water depth at $0.3 \mathrm{~m} .1 \mathrm{~m}$ deep zones to be excavated perpendicular to the flow for flow redistribution and for fish and submerged or floating aquatic vegetation habitat

- Minimum hydraulic retention time for a SF wetland is 7 to 10 days, for SSF wetland 2 to 4 days, and for a natural wetland 14 to 20 days

- Average hydraulic loading should be approximately $3 \mathrm{~cm} / \mathrm{d}$ or $3.3 \mathrm{ha} / 1,000$ $\mathrm{m}^{3} /$ day 
- $\quad$ Length to width ratios can be as low as $1: 1$. Lower length to width ratios result in lower construction costs.

- Shape and location of the treatment cell(s) can vary and depends on landscaping features required for attracting wildlife and for public enjoyment, and relief of available land.

Flow regime and control recommendations are as follows:

- Gravity flow is the preferred method of movement of wark into of the treatment wetland

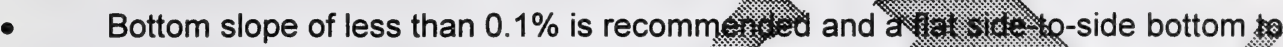
promote sheet flow through the system

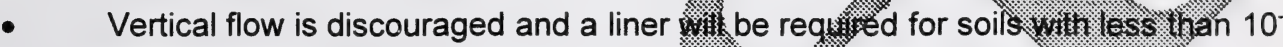
${ }^{6}$ permeability

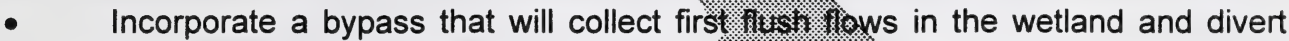
high flows during extreme rainfall events woungs, we wetland if high inflow/ infiltration is evident in the existing sanitary sewer.

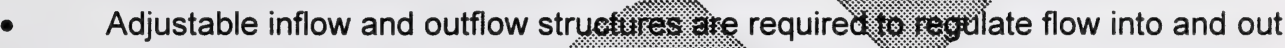

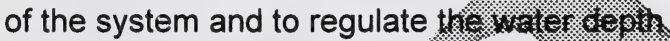

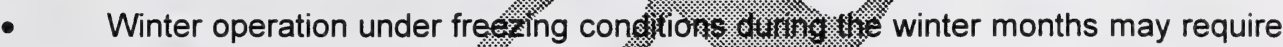

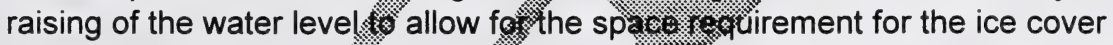

Ancillary benefits that increase the

- Landscaped features can previde an attrictive park-like setting

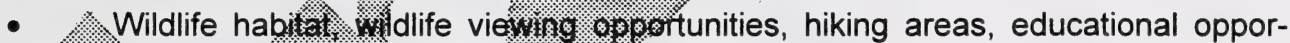
unities, restariation of tos. wetland areas that can be incorporated into the Hetand destogr.

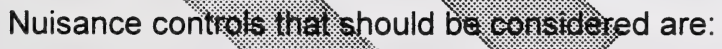

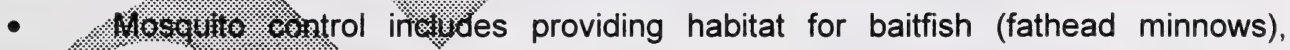
dragon if of onallows, and bats

Odour colluof s. niot required since the treatment wetlands, if designed properly, do not gestrate odours

- Nuisance wildlife including carp and muskrat will require control since they will destroy. or consume the wetland vegetation and will, in the case of the carp, resuspend settled materials

\section{Treatment Wetlands Operation}

The Canadian experience to date has been that most treatment wetlands in northern climates receive stored wastewater from a lagoon on a seasonal basis for optimum contaminant removal efficiency. Wetland systems can be operated through the winter months but must be over 
designed to compensate for the reduced contaminant removal rates during cold weather operation, particularly for nitrogen concentration reduction.

Continuous dischargers must concern themselves at the design stage with providing sufficient insulation to keep the treatment wetland from freezing. This has been accomplished by designing enough freeboard in the system to allow the water level to be raised in the fall, allowing the surface to freeze, and lowering the water level. The dead vegetation stalks will act as support structures for the ice sheet. The snow/ice/air gap can provide sufficien.insulation to allow continuous flow through the winter months, especially if the discharge is sufficiently warm. The construction of a SSF system will also reduce of potential of

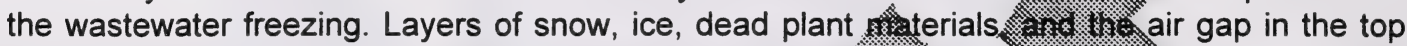
0.1 to $0.2 \mathrm{~m}$ of the gravel bed will provide an insulatisg barrier continuous discharge and meet discharge criteria, it will:

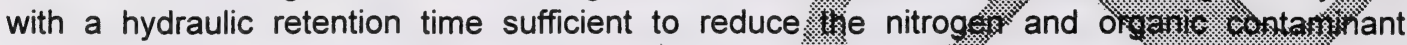

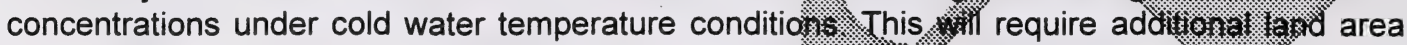
as compared to a seasonal system that would opestate. conditions.

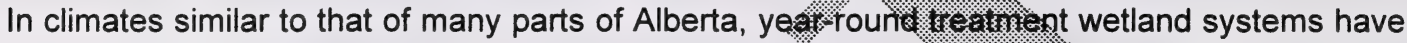

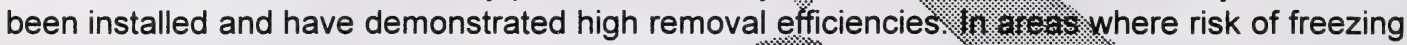

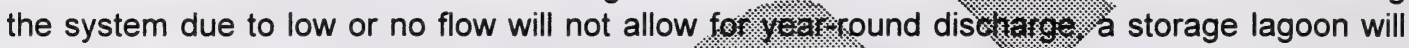

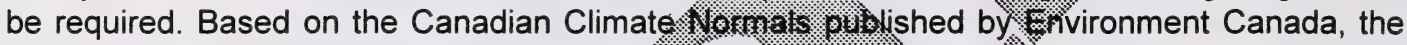
monthly average temperatures indicate kat, for. seasanal *ischarge system, treated

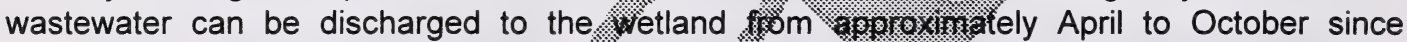

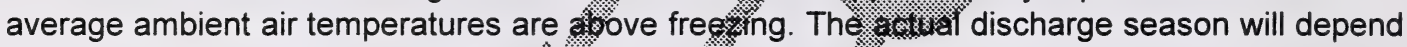

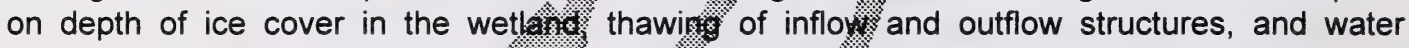
temperature above approximatel $\%$. For high nitrosien removal efficiencies under cold

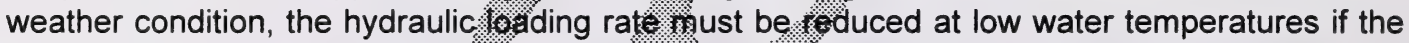
wetland has been designed for werm water of sation

\section{Capital, Operation, and Maintenance Costs}

Wetland construction costs are detemminod by the cumulative cost of land, earthwork, planting, design, monitoring an s. mintenanee. Surface flow constructed wetlands in the United States typically cos vetween. and Knight, 1996). Wetland sonstivuction costs that fell outside this range included those where a liner was required, specials attention was given to the removal and subsequent replacement of the topsoif, economy of scale was lost due to the small size of the installation, and/or special arehizectural features were incorporated into the wetland design so that it would be a more attractive feature for the surrounding community. The high cost of gravel fill can raise the price per hectare of subsurface flow wetlands to as much as about four times the cost of surface flow Wettands. Itowever, subsurface flow wetlands can handle greater contaminant loading rates than surtace llow wotlands reducing the land requirements.

Operation and maintenance costs depend upon the extent of monitoring data collection, exotic plant control, burrowing animal activity into the berms (animal control, berm repair), and water management. 


\section{Public Participation}

It is critical to maintain open communication with the communities adjacent to the chosen treatment wetland site. There is considerable misinformation and a lack of understanding of the benefits of treatment wetlands that could lead to strong opposition to this option for wastewater polishing. A public meeting with qualified environmental and treatment wetlands experts will provide a forum where questions about the natural treatment approach can be addressed. Questions and concerns that have been raised over the years include issues sucks:

- What about mosquitoes?

- Do we know enough about this relatively y@is technolis: design of the system?

- Will it continue to function in the winter?

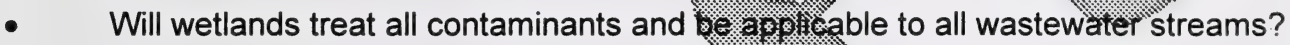

- $\quad$ Are there any large scale applications?

- Will storm events wash out accumulateo contamingis $\quad$ s.

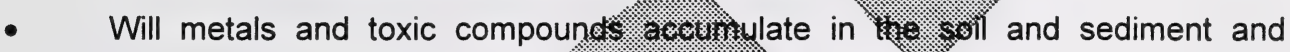
adversely affect the wildlife that

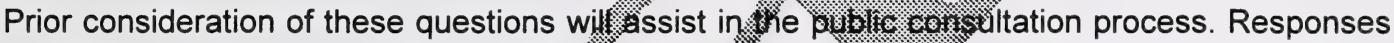
to these questions and others are found $\mathrm{K}$.

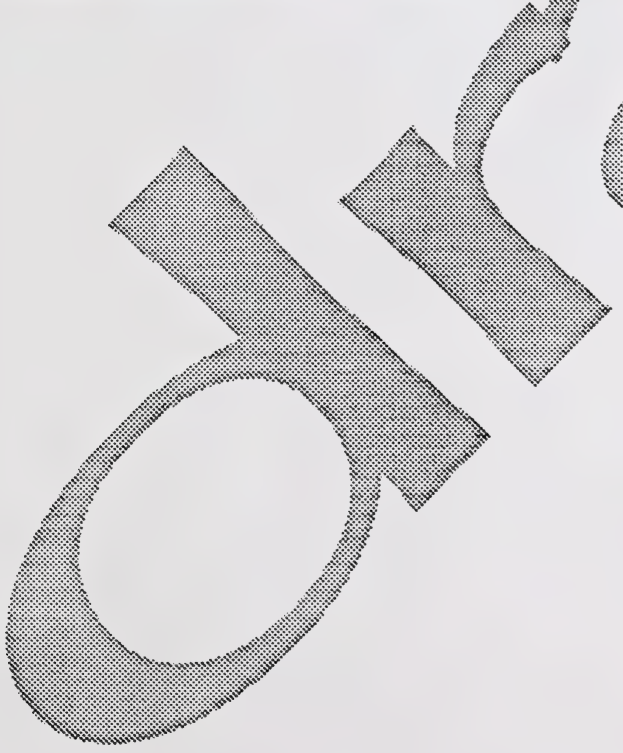





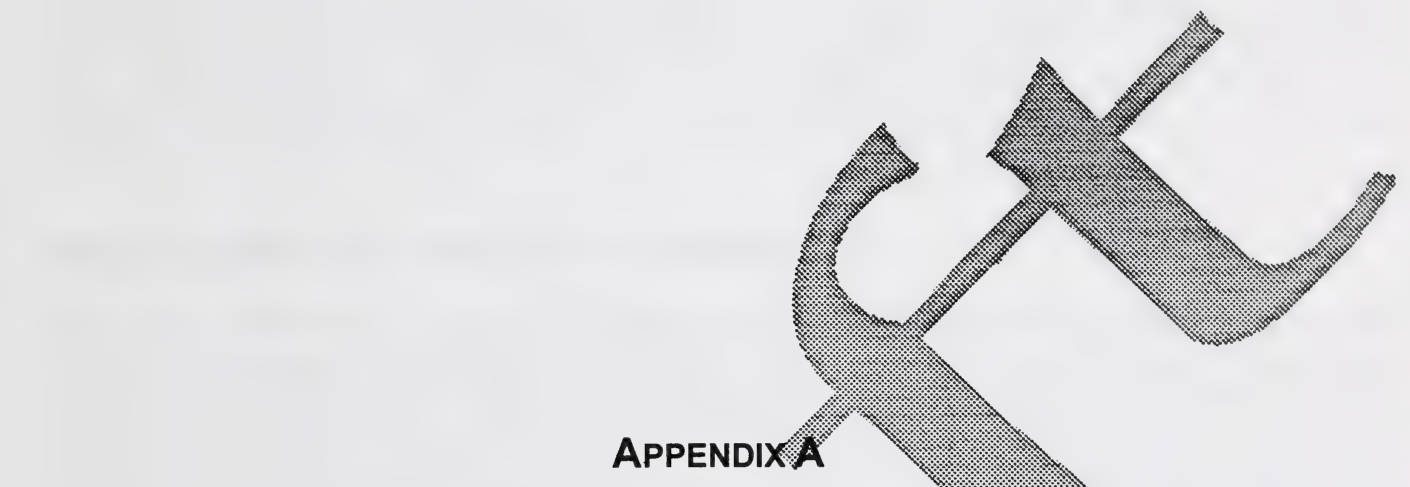
WETLAND APPLICATIONS 



\section{A. Wetland Applications}

The intent of this publication is to provide municipal planners and the farming community with enough information to consider wetlands treatment as a wastewater treatment alternative. However, there is a potential for applying this technology to a wider spectrum of wastewater and stormwater sources. Federal and provincial lands could benefit consterably from this technology since it offers a low cost alternative to moreconve of wastewater and stormwater treatment. A brief description of seve. potential uses is listed below.

\section{Municipal Wastewater Treatment}

Successful treatment of primary and secondary

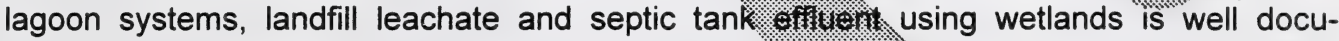
mented. Typically, these systems are applied to snall o.tmonunities where land is readily available at a reasonable cost. Many of the Canadian 2anoticztions that have been constructed in the colder climates have been designed for seassomit. o.s.scharge or to meet the

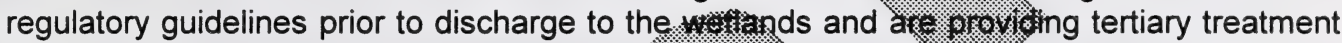
to the wastewater stream.

\section{Farm Feedlot/Agricultural Runoff}

Approximately 20 projects are *ing

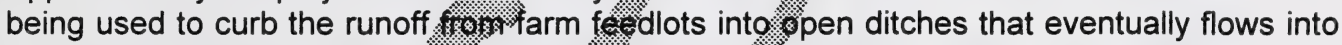
nearby water courses or perslates ints. we ground affecting the groundwater quality. The

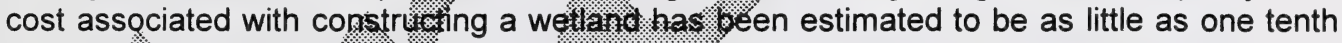

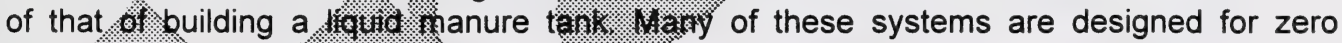

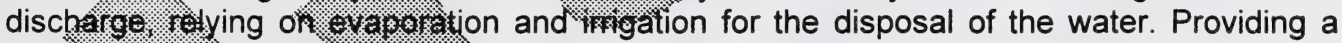

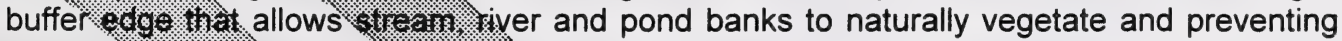

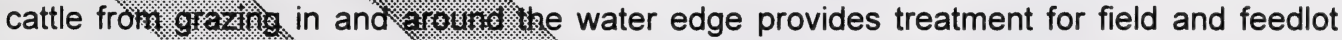
runoff.

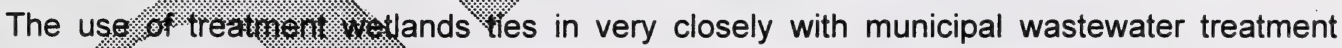
where. the farming villages, towns, and cities share a common watershed. The regulating autheritises. alternative to upgrading $>$ municipal wastewater treatment plant. The municipality provides source controls for sistected portions of the farming community equal to or greater than the anticipated loading. hicrease by the wastewater treatment plant. A treatment wetland is one of many source cortrols that are available to the farming community.

\section{National/Provincial Parks}

Campsites within national and provincial parks could benefit from the wetland technology from several standpoints. Since most parks operate on a seasonal basis, the design of these systems would not require that they be built to meet winter operation criteria and could easily be modified in the future if year-round operation was desired. Wetlands could be incorporated into the environmental education program although care would have to be 
taken to reduce the risk of campers coming into contact with the wastewater and the pathogens it may contain. Wetlands may be of particular interest to campsites located in the northern areas of Canada.

\section{First Nation Lands}

Native settlements are often in remote locations and are frequently poorly served by acceptable wastewater treatment facilities. Wetlands offer an opportunity for. wastewater and stormwater treatment alternative that will blend into the natural nviro is ient. Construc-

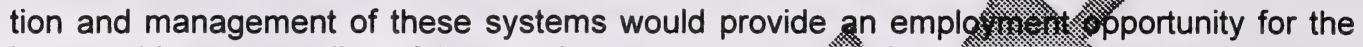

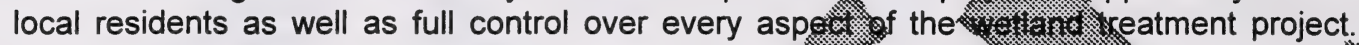

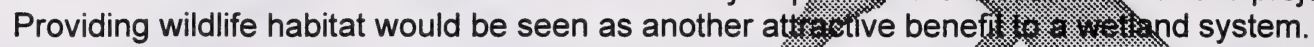

\section{Northern Communities}

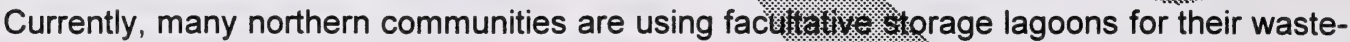
water treatment needs. Most have permits to dischlisge. me. lagoon contents during the

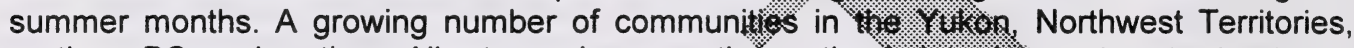

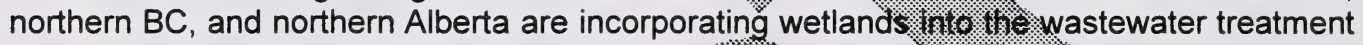

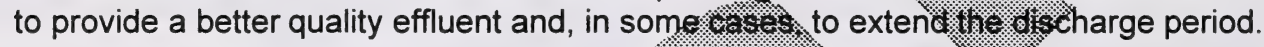

\section{Stormwater Treatment Wetlands}

Stormwater wetlands are constructex wetland that ims wove water quality, modify flow rates by storing water temporarily in sitallow porgls that chate growing conditions suitable for emergent and riparian wetland galants, atterguate flow:and reduce downstream scouring and erosion (MOEE, 1992 and Shivater, 1992. Shueler. designs: shallow marsh. 20 gid/wetland. exterides detention, pocket wetlands, and fringe

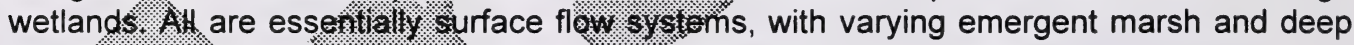
pool bolzat, and hydravtic areacity, residence time, and travel routes.

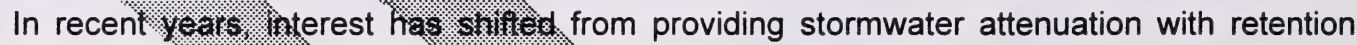
ponds alone, 10 incomorating. vegeroted wetland cells into the design to provide greater attenuation and combminant removal. The accompanying database indicates those communities with instaltes we wands as part of their stormwater management system and several that are awaiting approvol. men the regulating authorities or are in the predesign or design phase.

\section{Sludge Drying/Biosolids Management}

Management of studge solids from an activated sludge system has been carried out in the

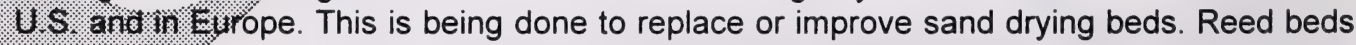
have been found to provide shorter dewatering times and reduced sludge volumes and organic material. 


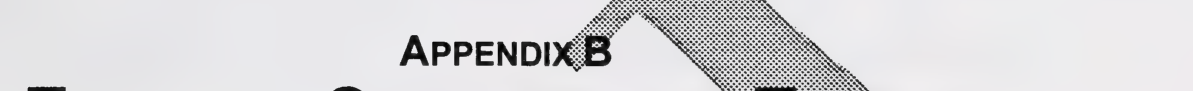

EXAMPLE CALCULATION TABLES FOR SF ANDSSF WETLANDS 

Appendix B - Alberta Environmental Protection - Wetlands Guidelines

Surface Flow (SF) Treatment Wetland - Preliminary Feasibility Calculation Sheet - Example

Instructions: Fill in the single outline boxes with data gathered in Section 1, then calculate the values for the double outlined boxes.

Location:

Design Flow, $\mathrm{m} 3 / \mathrm{d}$

$\mathbf{Q}=$

120

Influent Concentration

$c_{1}=$

$\begin{array}{lllllll}\text { TSS } & \text { BOD } & \text { TP } & \text { TN } & \text { NH4-N } & \text { Org-N } & \text { FC }\end{array}$

$c_{e}=$

\begin{tabular}{|l|l|l|l|l|l|l|}
\hline 15 & 30 & 3 & 3 & 20 & 25 & 200,000 \\
\hline
\end{tabular}

Target Effluent Concentration

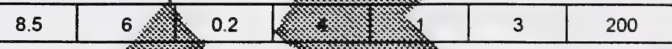

Wetland background limit, $\mathrm{mg} / \mathrm{L}$

$C^{*}=$

for TSS, $C^{*}=7.8+0.063 C_{\text {, }}$

for $B O D, C^{*}=3.5+0.053 C_{i}$

Areal rate constant @ $20^{\circ} \mathrm{C}, \mathrm{m} / \mathrm{yr}$

$k=$

Required wetland area, ha

$A=$

$A=\left(\frac{0.0365 \times Q}{k}\right) \times \ln \left(\frac{C_{i}-C^{*}}{C_{e}-C^{*}}\right)$

Effluent concentration, $\mathrm{mg} / \mathrm{L}$

via $\mathrm{k}-\mathrm{C}$ * model

$C_{0}=C^{*}+\left(C_{i}-C^{*}\right) \exp \left(-\frac{k A_{\max }}{0.0365 \times Q}\right)$

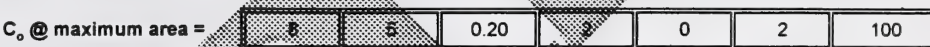

\begin{tabular}{|c|c|c|c|c|c|c|}
\hline 8 & 8 & 0.05 & & & & 100 \\
\hline 1000 & \% & 12 & 22 & 18 & 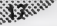 & 77 \\
\hline 0.009 & 34 & . & 0.5 & 0.7 & 0.7 & 0.4 \\
\hline
\end{tabular}

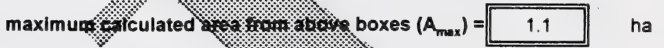


Appendix B - Alberta Environmental Protection - Wetlands Guidelines

Subsurface Flow (SSF) Treatment Wetland - Preliminary Feasibility Calculation Sheet - Example

Instructions: Fill in the single outline boxes with data gathered in Section 1, then calculate the values for the double outlined boxes.

Location:

Design Flow, $\mathrm{m}^{3} / \mathrm{d}$

Influent Concentration

Target Effluent Concentration

Wetland background limit, $m g /$

for TSS, $C^{*}=7.8+0.063 C_{\text {, }}$

for BOD, $C^{*}=3.5+0.053 C_{i}$

Areal rate constant @ $20^{\circ} \mathrm{C}, \mathrm{m} / \mathrm{yr}$.

Required wettand area, ha

$$
A=\left(\frac{0.0365 \times Q}{k}\right) \times \ln \left(\frac{C_{i}-C^{*}}{C_{e}-C^{*}}\right)
$$

Effluent concentration, $\mathrm{mg} /$.

via $\mathrm{k}-\mathrm{C}$ * model
$Q=$

120

$c_{1}=$

$c_{0}=$

$c *=$

$k=$

$A=$ $\begin{array}{llllllll}\text { TSS } & B O D & \text { TP } & \text { TN } & \mathrm{NH}_{4}-\mathrm{N} & \text { Org-N } & \mathrm{FC}\end{array}$

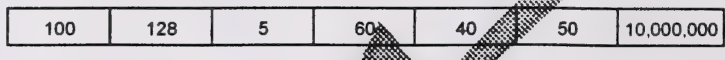

\begin{tabular}{|l|l|l|l|l|}
\hline 15 & 30 & 3 & 25 & 200,000 \\
\hline
\end{tabular}

\begin{tabular}{|c|c|c|c|c|c|c|}
\hline 14 & 3 & 0.05 & 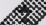 & & 1.5 & 100 \\
\hline 1000 & s & 7 & 22 & 18 & . & 77 \\
\hline 0.02 & 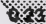 & 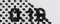 & 0.14 & 0.17 & 0.19 & 0.22 \\
\hline
\end{tabular}

maximum oulater.

ha

$$
\mathrm{C}_{0}=\mathrm{C}^{*}+\left(\mathrm{C}_{\mathrm{i}}-\mathrm{C}^{*}\right) \exp \left(-\frac{\mathrm{kA} \max }{0.0365 \times \mathrm{Q}}\right)
$$

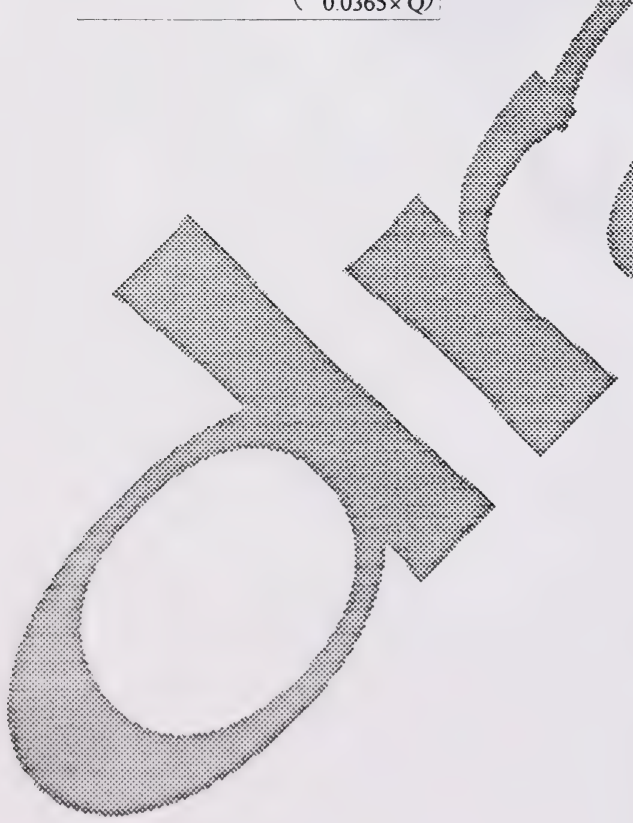




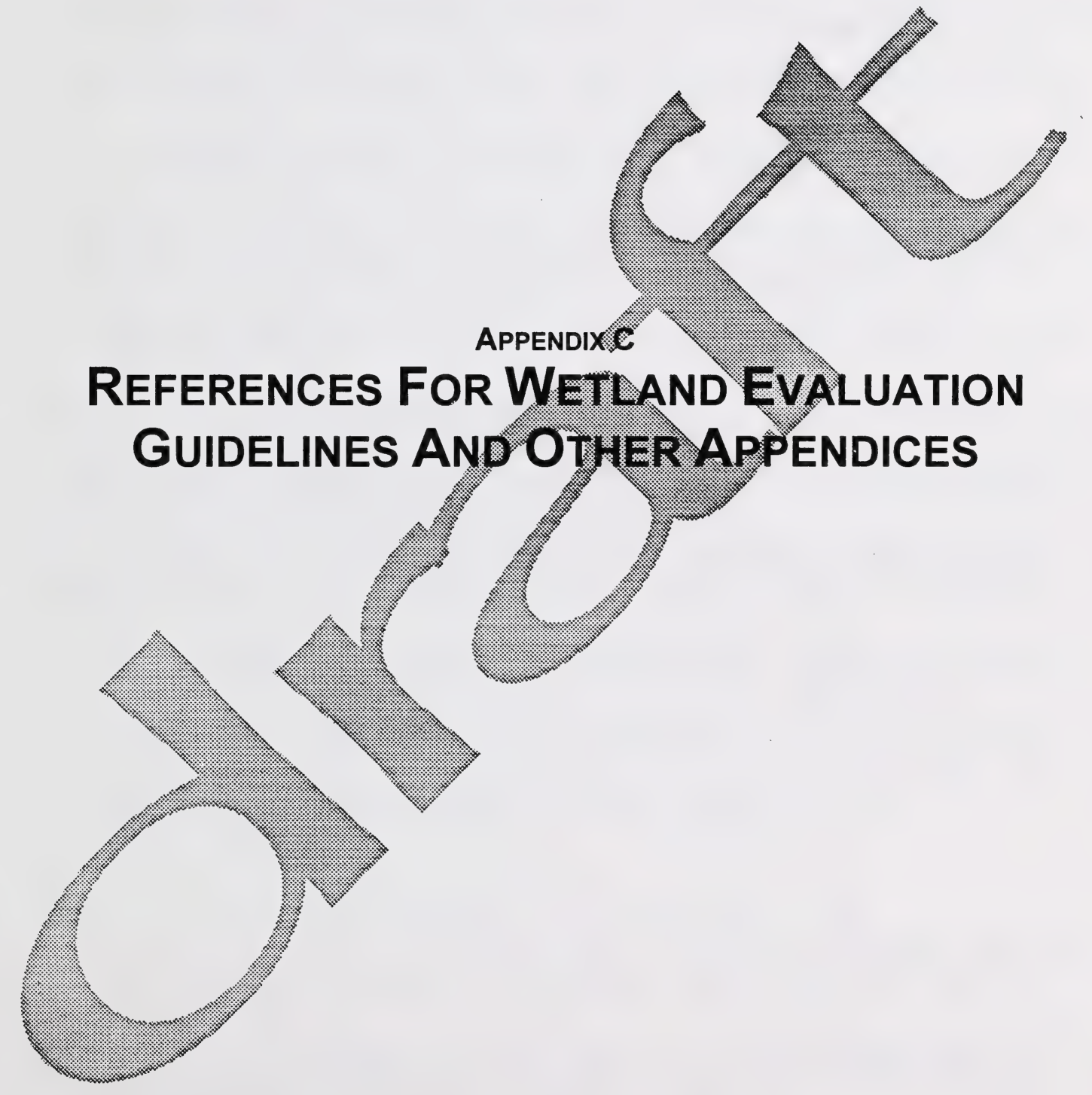





\section{References for Wetland Evaluation Guidelines and Other Appendices}

Alberta Department of Environmental Protection 1995. Alberta's Statement of the Environment: a Comprehensive Report. Publication 1/583, Alberta Environmen Protection.

Alberta Water Resources Commission. 1993a. Wetland Managem * in Settled Area of

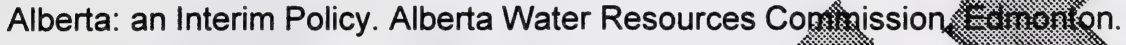

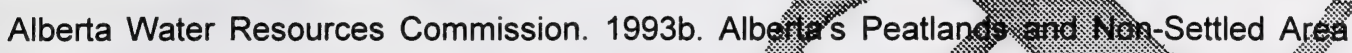

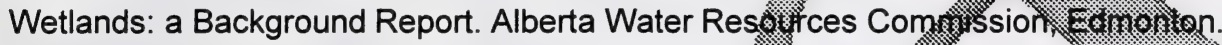

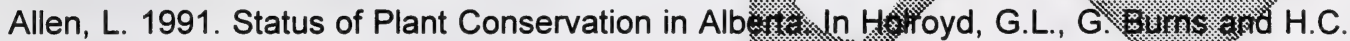
Smith. 1991. Proceedings of the Second Endangered gerecies and Prairie Eornservation Workshop. Provincial Museum of Alberta Natural Historg: :

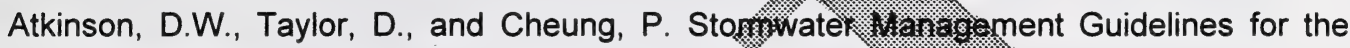
Province of Alberta. 1997.

Berry, D. 1995. Alberta's Walleye Management ans : qecovery Aalberta Environmental

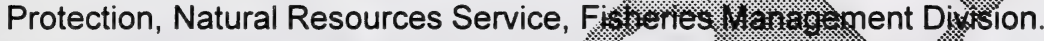

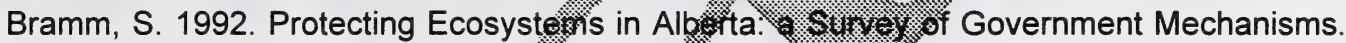
Environmental Council of Alberta, Edintonton, Alberta.

D.A. Westworth and Associates. Report for Wetlands Managemant Steering Commitse. North Petroleum Plaza, Edmonton, Alberta.

D.A. Westworth and 4 ssociates Ltd. 1890 . Bignificant Natural Features of the Eastern

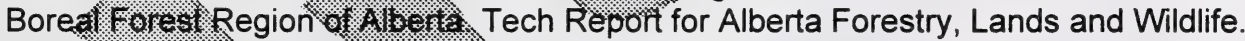

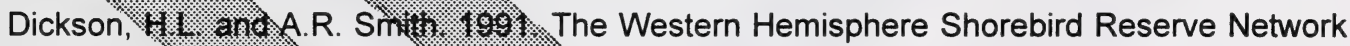
and the Prake Surgebird Program in Holroyd, G.L., G. Burns and H.C. Smith. 1991.

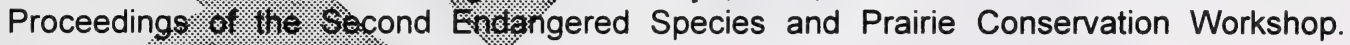

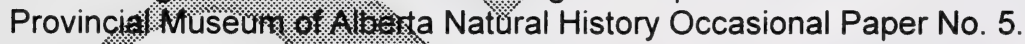

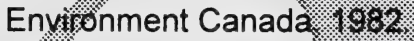

Kadlec, R.H. and R.L. Knight. Treatment Wetlands. Lewis Publishers. 1996.

Whight, R.L., Payne (v., Pries, J.H., Borer, R., Clarke, R. Constructed Wetlands for Livestock Wastewater Manasement - Literature Review, Database, and Research Synthesis. Gulf of Wexiso Programis: 1997.

Verteng. I. J. Wilk, K. Woolnough and B. Hoskins. 1985. Wildlife Habitat Requirement Summaries for Selected Wildlife Species in Alberta. Alberta Energy and Natural Resources (ENR Technical Report T/73), Fish and Wildlife Division, Edmonton.

Packer, J.G. and C.E. Bradley. 1984. A checklist of the Rare Vascular Plants of Alberta. Provincial Museum of Alberta Occasional Paper No. 5. 
Paetz, M.J. and J.S. Nelson. 1970. The Fishes of Alberta. Government of Alberta, Edmonton. 282 pp.

Posey, M. 1992. Saving the Strands of Life. Alberta's Biodiversity. Environmental Council of Alberta, Edmonton.

Poston, B., D.M. Ealey, P.S. Taylor and G.B. McKeating. 1990. Priority Migratory Bird Habitats of Canada's Prairie Provinces. Habitat Conservation Section, Canadian Wildlife Service, Western and Northern Region, Environment Canada, Edmonton, Albs

Pries, J.H. Wastewater and Stormwater Applications of Wetlands Pan

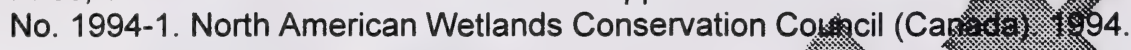

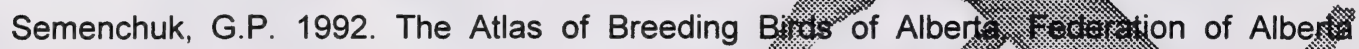
Naturalists, P.O. Box 1472, Edmonton, Alberta.

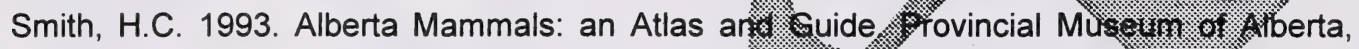
Edmonton, Alberta.

Strong, W.L., B.K. Calverley, A.J. Richard and G. W. Sintert 1993. Characterization of

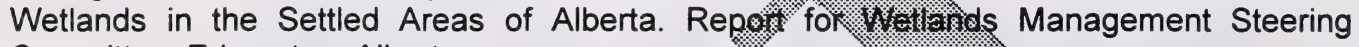
Committee, Edmonton, Alberta.

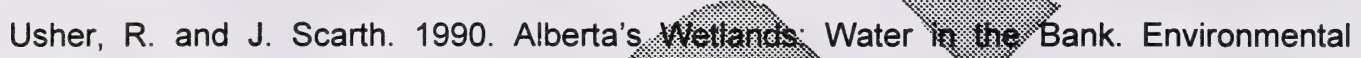
Council of Alberta, Edmonton, Alberta.

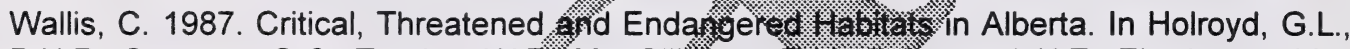

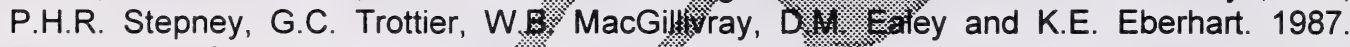
Endangered Species in the Prairt: Provinees. Provilicial Museum of Alberta Occasional Paper No. 9.

Wildlife Management Division. 1996. The Status of Alberta Wildlife. Alberta Environmental Protection, Natural Resources Service, womomon. 


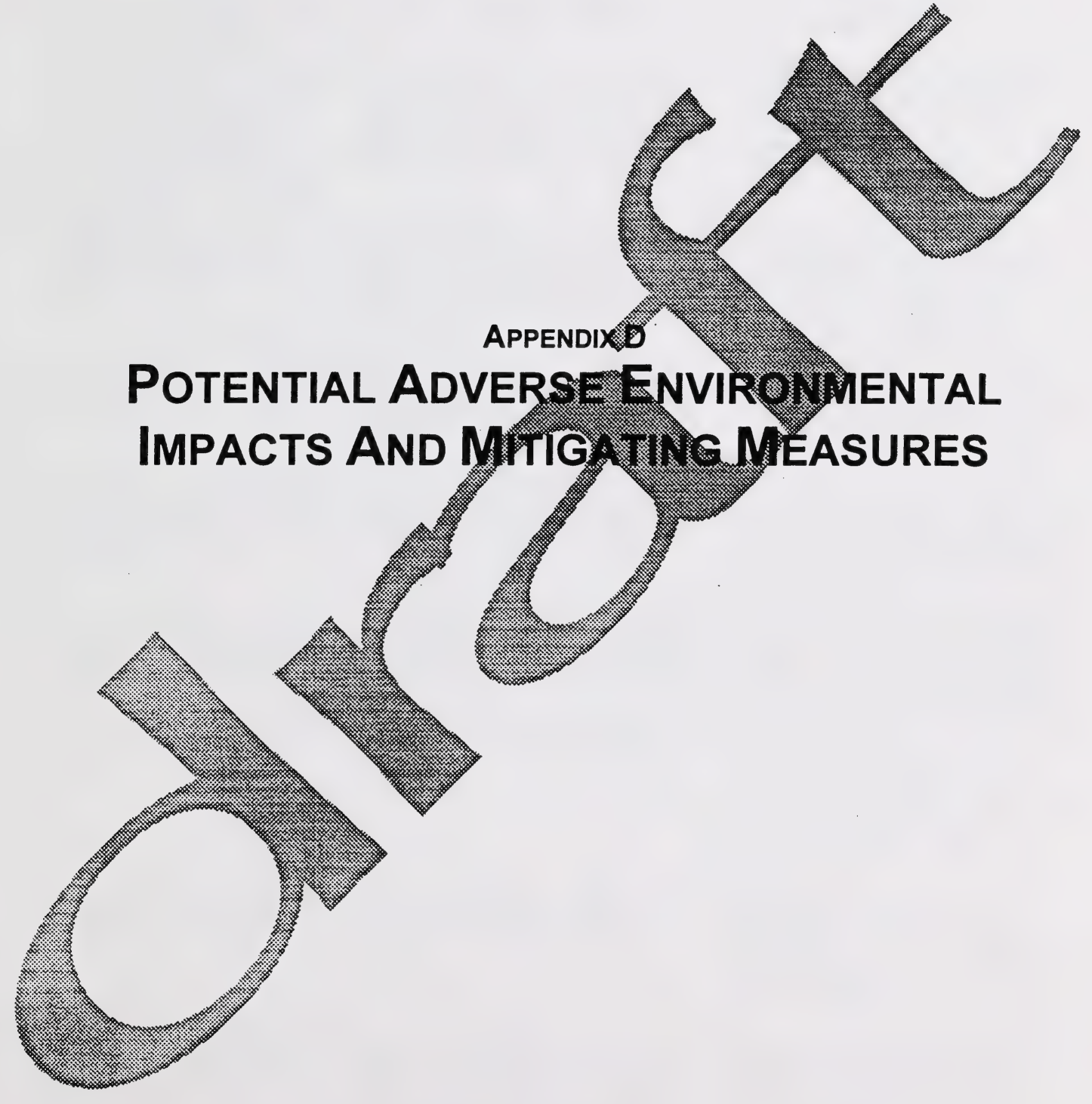





\section{Potential Adverse Environmental Impacts and Mitigating Measures}

\begin{abstract}
Direct effects

\begin{tabular}{l} 
Direct effects \\
\hline Increase in nutrient input \\
\hline Replacement of plants adapted to \\
nutrient-poor conditions (e.g. bog, \\
fen, shoreline and prairie plants; \\
many rare) with plants adapted to \\
nutrient-rich conditions (e.g. \\
cattails, bulrushes; generally more \\
common spp.).
\end{tabular}
\end{abstract}

Weedy species which out-compete native species may invade and establish dense stands.
Increase in nutrient input may result in eradication of some native plant communities which are often adapted to a narrow w. nutrient conditions; weedy species $\%$ outcompete native species may invad
Indirect Effects

\author{
Mitigation
}

Characteristically low sedge brod foraging habitat for waterfowl, sho. aquatic mammals may be replaced tall stands; possible positive impact increasing concealing cover.
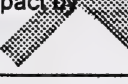

Algal blooms shade out floating and Forage species for some walled; submergent species. impacts on rare submerf

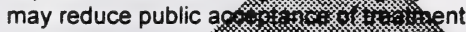
wetland.

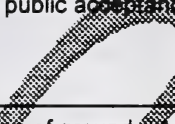

Contaminat of ground shallows.

Contaminated surface water
enter local aquifer through recharge.

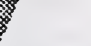

wat multi-cell treatment wetlo . . reduce nutrient loadin cells to levels ty of o. wast . . . W * t. titions.

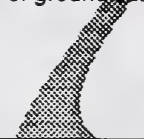

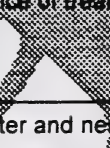

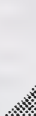

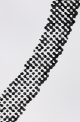

Furt hent of incoming waste-

\begin{tabular}{|c|c|c|}
\hline $\begin{array}{l}\text { Change in wor chemistry may } \\
\text { decrease } \\
\text { organisto }\end{array}$ & $\begin{array}{l}\text { er trophic lotions may } \\
\text { ease since prey spectick these animals. }\end{array}$ & $\begin{array}{l}\text { Further pretreatment of incoming waste- } \\
\text { water; construct multi-cell treatment wet- } \\
\text { land in series to reduce nutrient loadings } \\
\text { in the initial cells to levels typical of pre- } \\
\text { wastewater conditions. }\end{array}$ \\
\hline $\begin{array}{l}\text { General decreas } \\
\text { diversity. }\end{array}$ & divet & $\begin{array}{l}\text { Restoration of habitat by creating low } \\
\text { grade slopes (no more than } 1: 10 \text { ) in } \\
\text { some areas where a variety of plants can } \\
\text { recolonize, replanting shrubs and trees in } \\
\text { areas peripheral to the wetland; confine- } \\
\text { ment of impacts to least diverse areas. }\end{array}$ \\
\hline $\begin{array}{l}\text { wessity of restricting a } \\
\text { wetland. }\end{array}$ & $\begin{array}{l}\text { Possible negative affects on public accep- } \\
\text { tance; but positive affects for wildlife. }\end{array}$ & $\begin{array}{l}\text { Education and signage; provision of } \\
\text { public access in acceptable (e.g. peri- } \\
\text { pheral) parts of the wetland; enhance- } \\
\text { ment of access elsewhere by provision of } \\
\text { trails, other amenities. }\end{array}$ \\
\hline \multicolumn{3}{|l|}{ 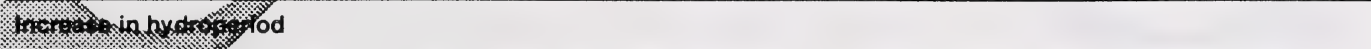 } \\
\hline $\begin{array}{l}\text { Wend to be killed off } \\
\text { anex } \\
\text { species. }\end{array}$ & $\begin{array}{l}\text { Reduction of habitat for forest-dependent } \\
\text { species; potential elimination of habitat for } \\
\text { species requiring large tracts of unbroken } \\
\text { habitat (i.e. protected interior areas away from } \\
\text { forest edge); potential effect on rare forest } \\
\text { species. }\end{array}$ & $\begin{array}{l}\text { Enlarge habitat by tree-planting or } \\
\text { allowing vegetation at forest edge } \\
\text { (increasing the area of forest-interior); } \\
\text { improve linkage with other habitats; } \\
\text { incorporate upland areas that will support } \\
\text { woody species into wetland design. }\end{array}$ \\
\hline
\end{tabular}


Direct effects
Indirect Effects

Tree removal will affect the amount of sunlight reaching water and affect plant productivity and increase watercourse temperatures.

\section{Mitigation}

Plant trees in strategic parts of the wetland to minimize impact on water temperature; incorporate upland areas that will support woody species into wetland design.

Increase in flooded area; water levels are more consistent, with fewer fluctuations.
Potential positive impact for waterfowl by increasing permanence of wetland, area of standing water.

Flooding of nests over or near water, flooding of low bank burrows/nests; erosion of h. Downstream flooding at periphery of . chd with attendant social cost; reduced s of treatment wetland.
If waterfowl are to be discouraged from using the site due to stringent effluent requirements, design sto wetland to minimize open wat. and $\mathrm{br}^{2}$ ing ar

Crea . . Witat above the floodline; $\mathrm{spc}$. . . . . lost habitat.

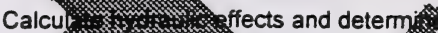

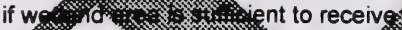

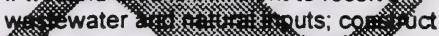

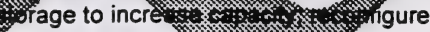
ठutflow area to inc . . . . . . .

Flooding of lower littoral zone and potential elimination of zone of annual plant species (often rare) which germinate when water levels fall. foraging areas by shorebirds, wateis................
Elimination of brood habitat, mud ................. increase in inundation time may elim . . some invertebrates.

Engineer shoreline (aknery of wetJand or on created habitat islands) with . ... - . ote zonation of emergent plant W. provide storage or alternate

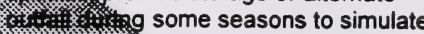
4........... Fevel fluctuations; divert w. . . . . mud flats and areas of late- $\%$ minating vegetation.

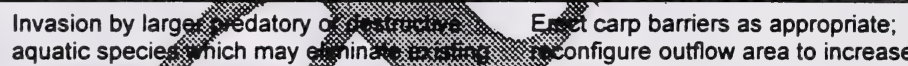
aquatic specied wich may ef in ................ species; e.g. Iffrogs may a caus decline in I gard frogs; op have wio ... impacts. Fetland ves.
Creation of larger, deeper water body.

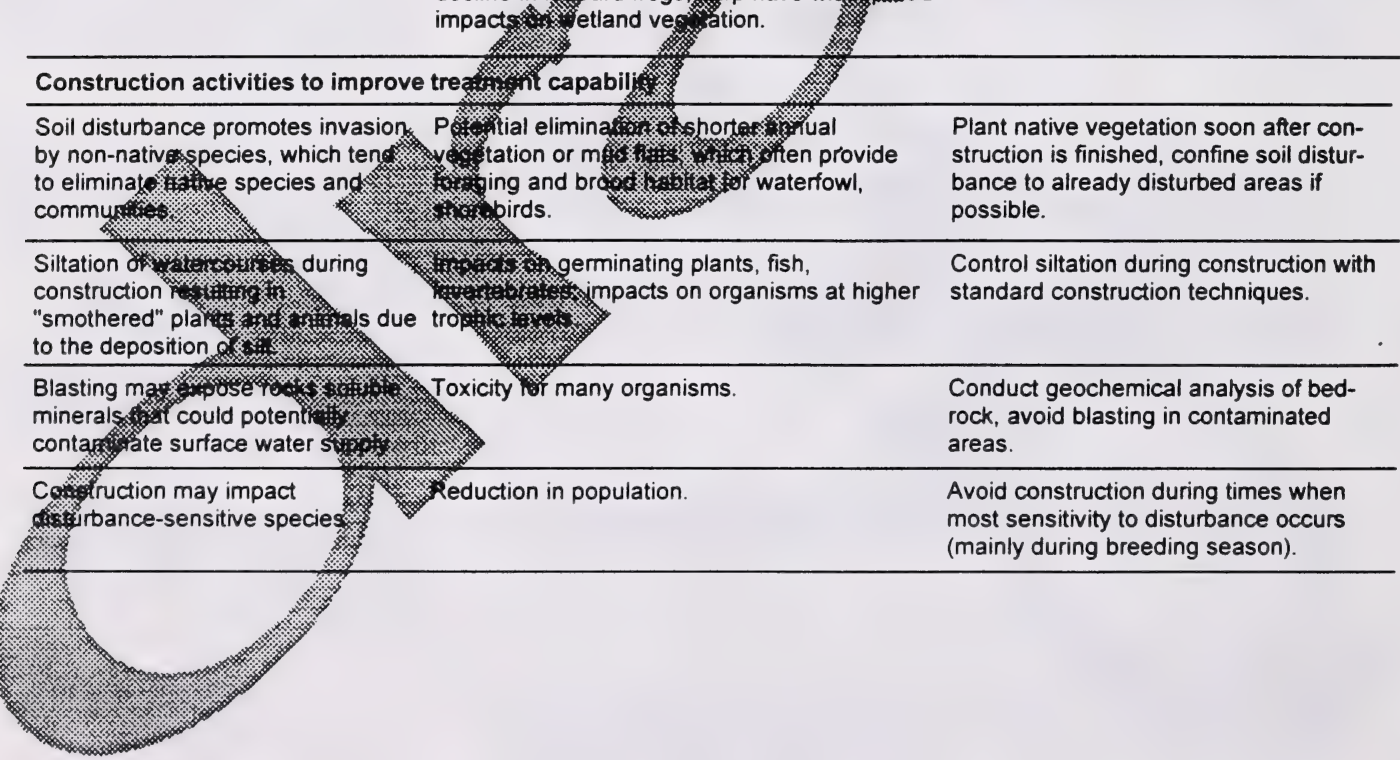




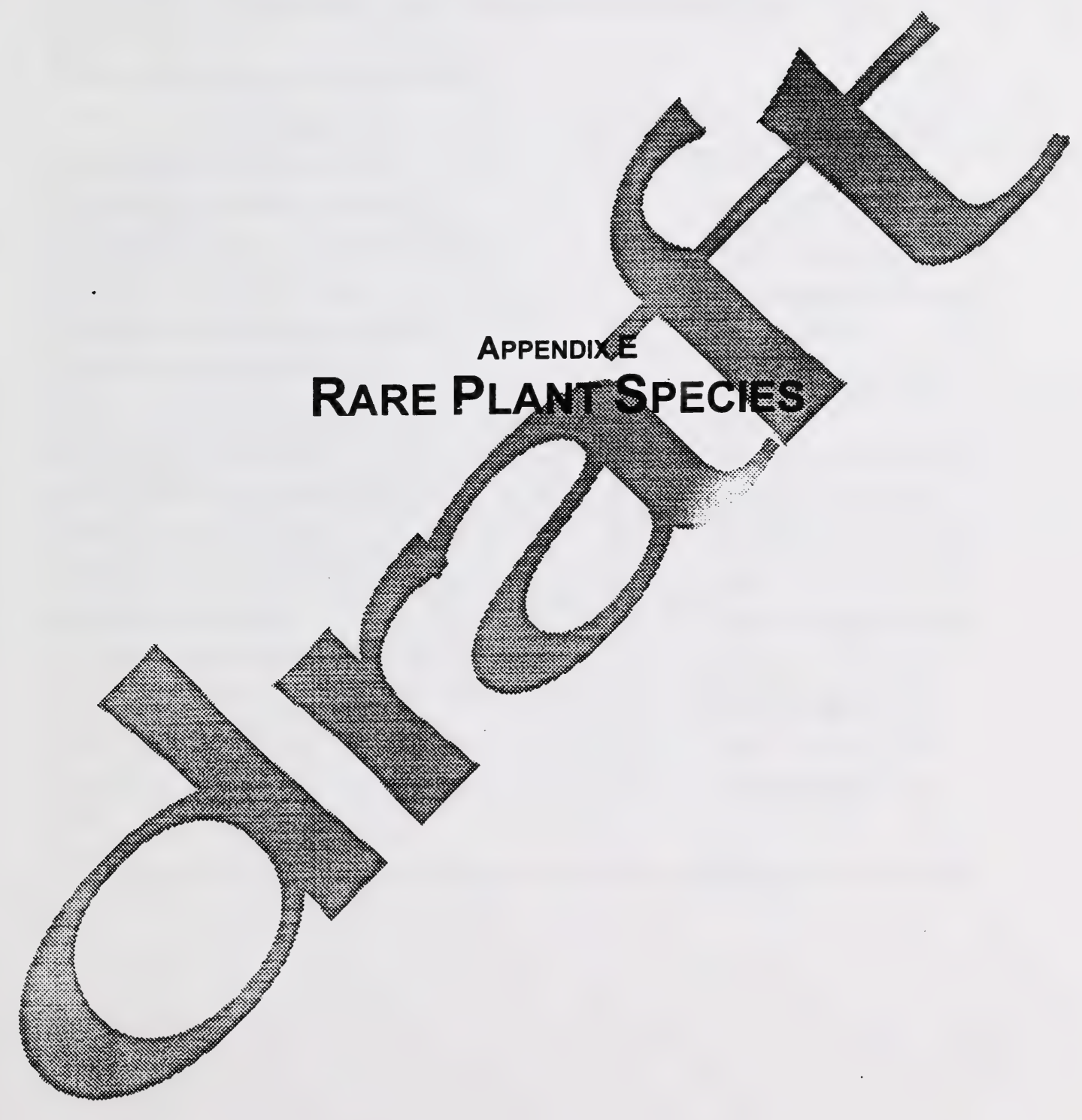





\section{E. Rare Plant Species}

A complete list of Alberta's rare flora (360 species) is found in Packer and Bradley (1984). This listing is being revised, but revisions are not yet complete. The following notes significant wetland species listed by D.A. Westworth and Associates Ltd., 1993.

\section{PART 1}

Significant Plants of Alberta Wetlands

\begin{tabular}{|c|c|c|}
\hline Plant Species & Stat & Type \\
\hline \multirow{2}{*}{\multicolumn{3}{|c|}{$\begin{array}{l}\text { Braun's Quillwort )/soetes echinospora) } \\
\text { Floating Bur-reed (Sparganium fluctuans) }\end{array}$}} \\
\hline & & \\
\hline \multirow{2}{*}{\multicolumn{3}{|c|}{$\begin{array}{l}\text { Blunt-leaved Pondweed (Potamogeton obtusifolius) } \\
\text { Widgeon-grass (Ruppia manitima) }\end{array}$}} \\
\hline & & \\
\hline Flowering quillwort (Lilaea scilloides) & & ugh margins and mudflats \\
\hline \multicolumn{3}{|c|}{ Broad-leaved Arrowhead (Sagittaria latifolia) } \\
\hline \multicolumn{3}{|c|}{ Tall Manna Grass (Glyceria elata) } \\
\hline \multicolumn{3}{|l|}{ Prairie Cord Grass (Spartina pectinata) } \\
\hline \multicolumn{3}{|l|}{ Porcupine Sedge (Carex hystricina) } \\
\hline \multicolumn{3}{|l|}{ Kellog's Sedge (Carex kelloggii) } \\
\hline Nevada Bullrush (Scipus nevadensis) & & Wine Pond Margins \\
\hline \multicolumn{3}{|l|}{ Geyer's Wild Onion (Allium geyen) } \\
\hline \multicolumn{3}{|c|}{ Western Blue Flag (Iris missouriensis) } \\
\hline \multicolumn{3}{|c|}{ Small White Water-lily (Nymphaea to } \\
\hline Waterwort (Elatine triandra) & & Muddy shores/shallow water \\
\hline Low Yelloxvening-primros & R & Wetland margins/clay flats \\
\hline Lance-1, wo, & $\mathbf{R}$ & Lake and Pond margins \\
\hline 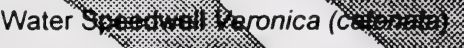 & $\mathrm{R}$ & Lake and pond margins \\
\hline Downingia ( ) ( & $\mathrm{R}$ & Alkaline margins of ponds \\
\hline Tall Beggar's-Th frondosa) & $\mathrm{R}$ & Lake and pond margins \\
\hline
\end{tabular}

\section{Notes:}

$R=R$ a

En = Endangered: specie, it s.

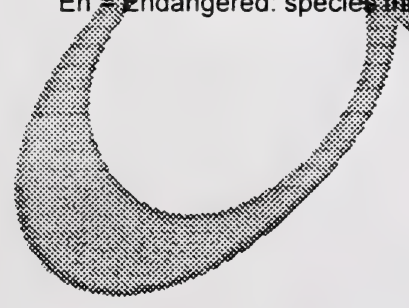




\section{PART 2}

Plant species of Threatened or Endangered Status in Alberta

\begin{tabular}{|c|c|c|c|}
\hline Species & Status & Habitat & Reason for decline \\
\hline \multicolumn{4}{|l|}{ Southwestern Alberta } \\
\hline Allium geyeri & $\mathrm{E}$ (Allen 1991) ${ }^{1}$ & Wet meadows and stream banks & $\begin{array}{l}\text { ed distribution } \\
\text { destruction }\end{array}$ \\
\hline Castilleja cusickii & E (Allen 1991) & Moist meadows an & \\
\hline Cypripedium montanum & E (Allen1991) & Moist woods & \\
\hline Inis missouriensis & E (Allen 1991) & Moist meadov & \\
\hline Astralagus lotiflorus & T (Allen 1991) & Dry slopes a & \\
\hline \multicolumn{4}{|c|}{ Sand Dunes of Prairies and Parklands } \\
\hline Cyperus schweinitzii & E (Allen 1991) & Sand dune & $\begin{array}{l}\text { Duny } \\
\text { these s/ } \\
\text { active dunes }\end{array}$ \\
\hline Tradescantia occidentalis & E (Allen 1991) & Sand dunes & \\
\hline Abronia micrantha & T (Allen 1991) & Sand dunes & \\
\hline Chenopodium subglabrum & $T$ (Allen 1991) & Sand dunes & \\
\hline Lygodesmia rostrata & $\mathrm{T}$ (Allen 1991) & Sand $x_{3}=1$ & \\
\hline
\end{tabular}

Legend:

$\mathrm{T}=$ Threatened: species likely to become endap if the i. . them vulnerable are not reversed.

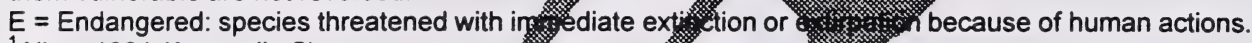

${ }^{1}$ Allen, 1991 (Appendix C)

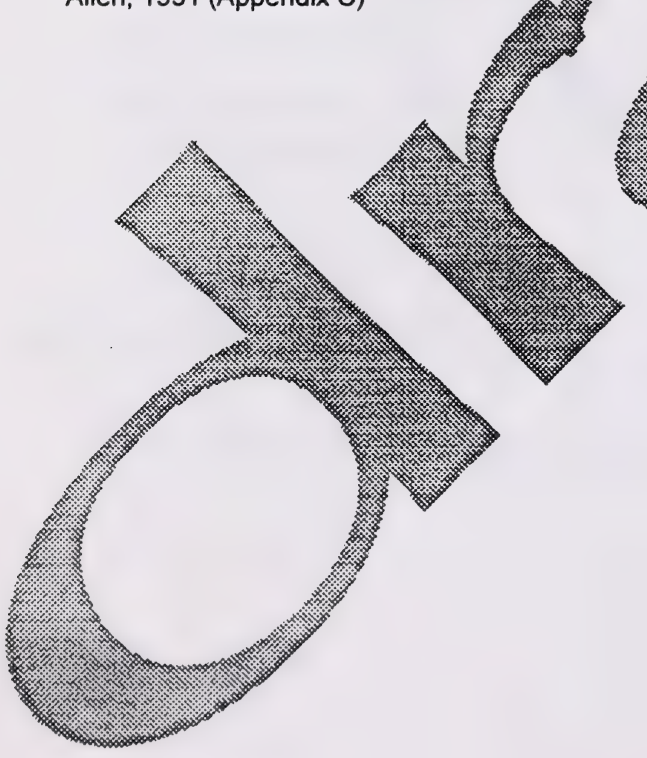




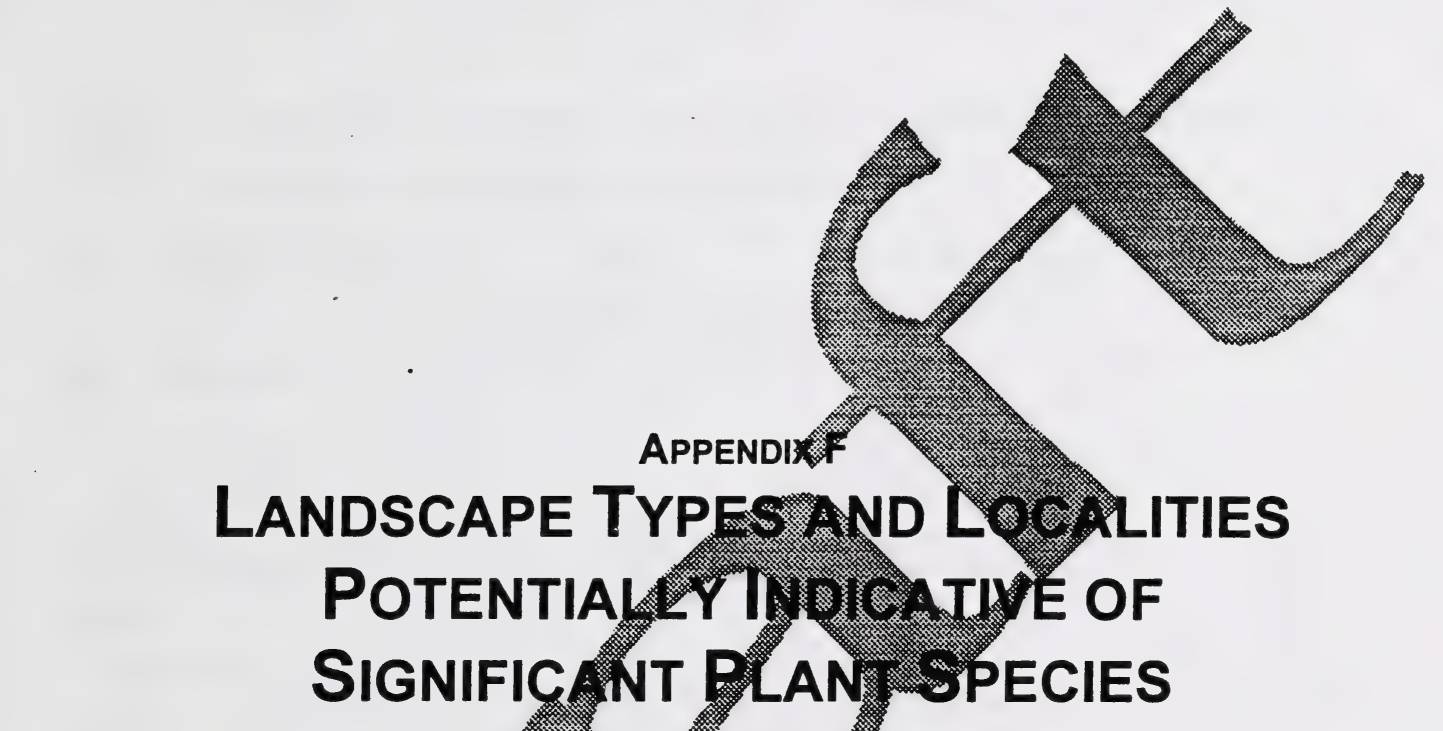


- 


\section{F. Landscape Types and Localities Potentially Indicative of Significant Plant Species}

PART 1

Relative Occurrence of Landscape Types based on the Pre-Europed, ; \& of Each Type in ALBERTA (FROM COTTONWOOd CONSULTANTS INC., 1983; IN WALLIS, 19

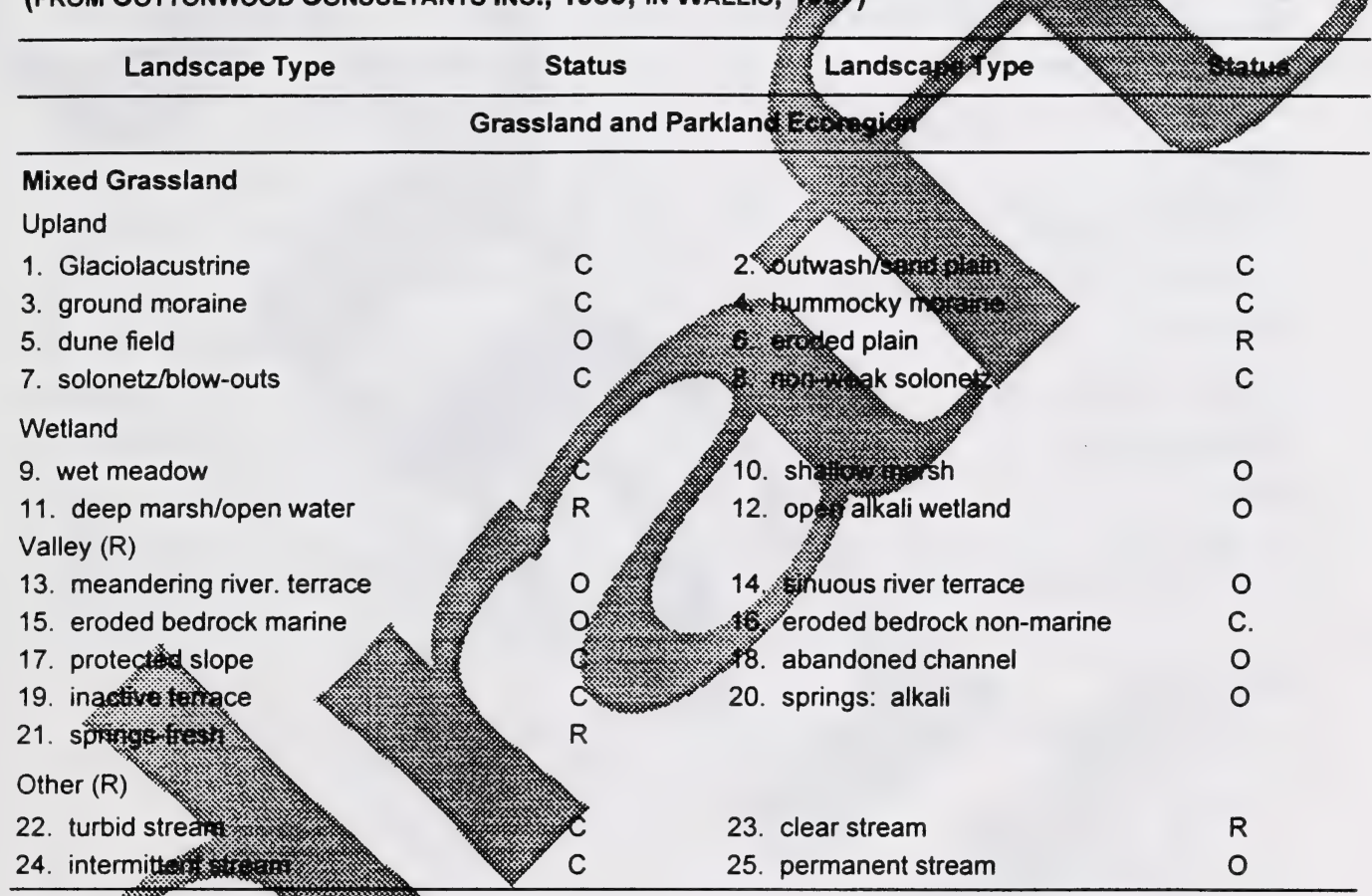

Northes: Fescue Grasus. Upleing (C)

1 . glaciolacustrine (fine)

\%.

5. dune field

7. . olonetz

1.6. 6.120

2.

11. deep marsh/open water

13. fresh/sl. alkali lake

Valley (R)

15. meandering river terrace

17. eroded bedrock

19. inactive terrace

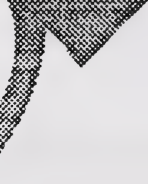

C

C

O

C

2. outwash/sand plain

C

4. hummocky moraine

6. eroded plain

C

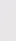

8. non/weak solonetz

C

10. shallow marsh

C.

O

12. open alkali wetland

$R$

C

14. alkali lake

C

R 16. sinuous river terrace $\quad 0$

18. protected slope C

C 20. abandoned channel $R$ 
PART 1

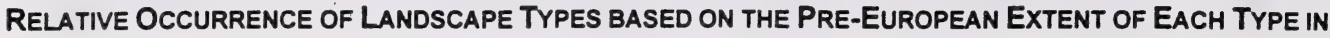
ALBERTA

(FROM COTTONWOOD CONSULTANTS INC., 1983; IN WALLIS, 1987)

\begin{tabular}{lclc}
\hline \multicolumn{1}{c}{ Landscape Type } & Status & \multicolumn{1}{c}{ Landscape Type } & Status \\
\hline 21. springs: fresh & $\mathrm{R}$ & 22. springs: alkali & $\mathrm{O}$ \\
Other $(\mathrm{R})$ & & & \\
23. clear stream & $\mathrm{R}$ & 24. turbid stream & $\mathrm{C}$ \\
25. permanent stream & $\mathrm{O}$ & 25. intermittent strea & $\mathrm{C}$ \\
\hline
\end{tabular}

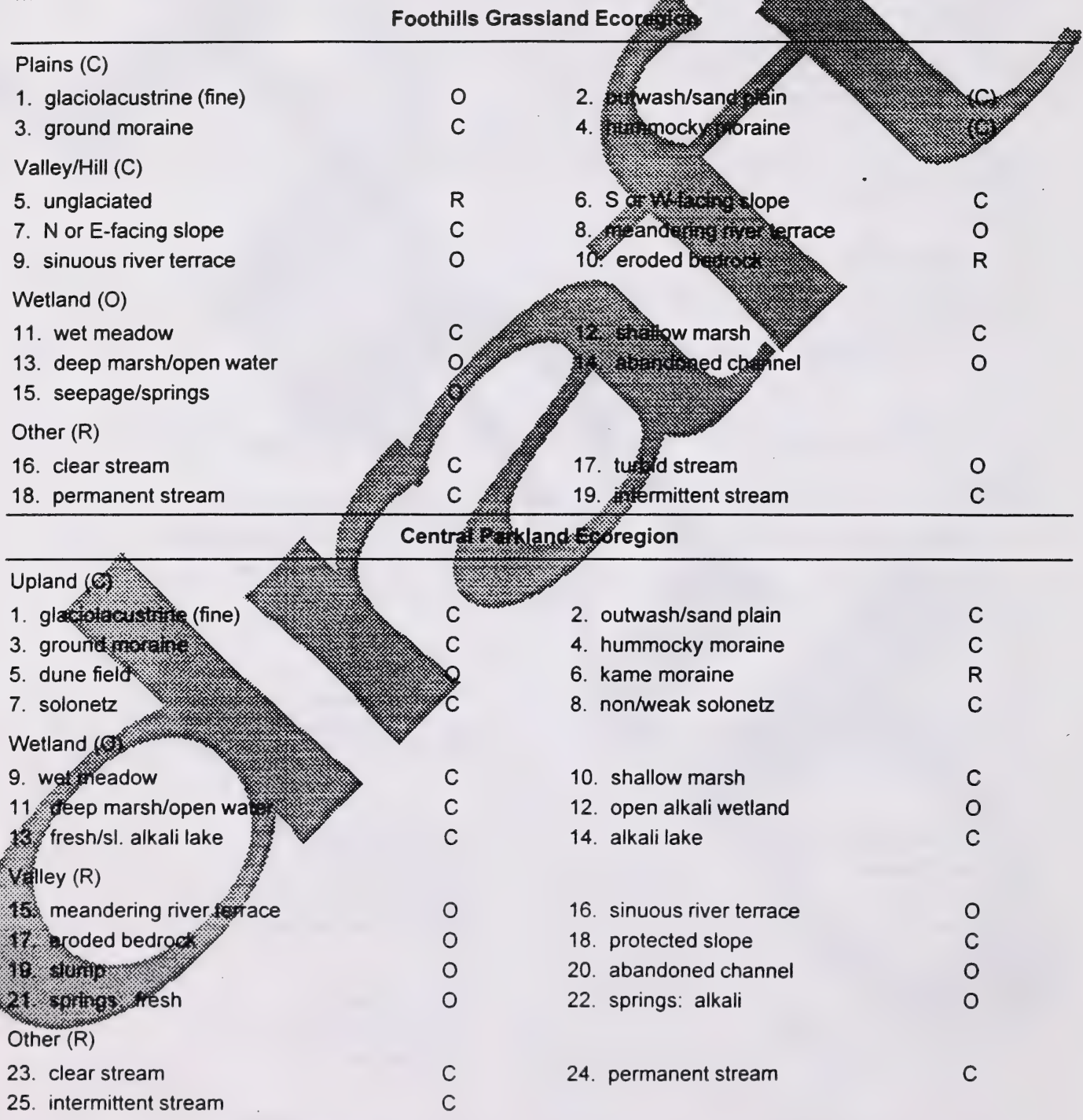




\section{PART 1}

Relative OccurRence of LANDSCAPE Types based on the PRE-EuRopean Extent of EAch Type in ALBERTA (FROM COTTONWOOD CONSULTANTS INC., 1983; IN WALLIS, 1987)

\begin{tabular}{|c|c|c|}
\hline Landscape Type & Landscape Type & Status \\
\hline \multicolumn{3}{|c|}{ Foothills Parkland Ecoregion } \\
\hline \multicolumn{3}{|l|}{ Plains (O) } \\
\hline 1. glaciolacustrine (fine) & 0 & \\
\hline 3. ground moraine & C & \\
\hline \multicolumn{3}{|l|}{ Valley/Hill (C) } \\
\hline 5. meandering river terrace & 6. qus ri terrace & \\
\hline 7. eroded bedrock & 8. m valley & \\
\hline 9. protected slopes & . & \\
\hline
\end{tabular}

Wetland $(O)$

10. wet meadow

12. deep marsh/open water

14. seepage/springs

Other $(R)$

15. clear stream

Legend:

$R=$ Rare

$\mathrm{O}=$ Occasional

$\mathrm{C}=$ Common

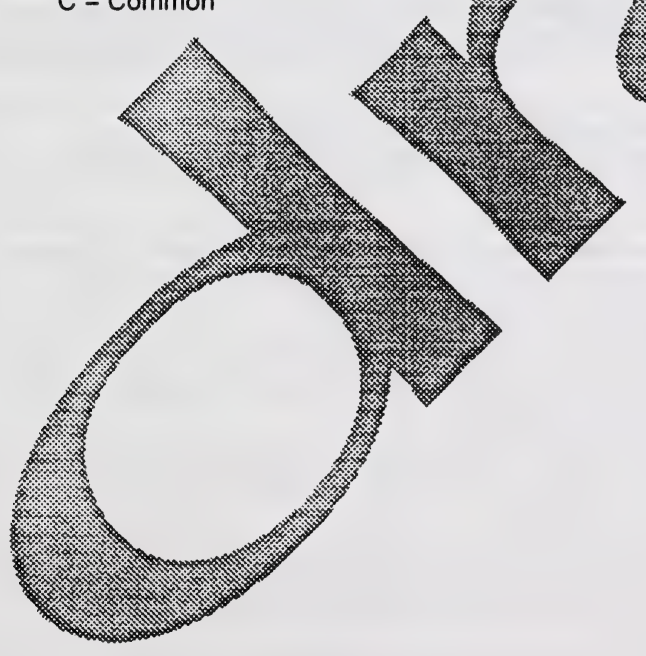




\section{PART 2}

EXAMPLES OF INDIVIDUALLY NOTEd SIgNIFICANT LANDSCAPES OR PLANT COMMUNITIES IN GRASSLAND, PARKLAND, AND BOREAL REgIONS (WALLIS, 1987; D.A. WESTWORTH \& ASSOCIATES, 1990, BRAMM, 1992: SEE APPENDIX C))

\begin{tabular}{|c|c|}
\hline Location & Feature \\
\hline \multicolumn{2}{|l|}{ Foothills Parkland/Foothills Grassland } \\
\hline $\begin{array}{l}\text { Southernmost portion of the foothills parkland in } \\
\text { the Waterton/Paine Lake area }\end{array}$ & $\begin{array}{l}\text { The largest conefintration o or at periphery of } \\
\text { range: unglac. }\end{array}$ \\
\hline $\begin{array}{l}\text { Little Bluestem prairie located northwest of Fort } \\
\text { MacLeod }\end{array}$ & Vegetation \\
\hline \multicolumn{2}{|c|}{ Wet meadow site in Police Outpost Provincial Park Wet mead with end } \\
\hline The Ross Lake area of the Milk River Ridge & Prime areaviant foothills grassland \\
\hline Mineral Springs along Boundary Creek & Rare plant ss \\
\hline Oldman and Belly Rivers & $\begin{array}{l}\text { The most gensivit cottonwood stands in } \\
\text { Canada }\end{array}$ \\
\hline Big Hill Springs Provincial Park & Raxw \\
\hline \multicolumn{2}{|l|}{ Central Parkland } \\
\hline Hummocky moraine near Rumsey & Larges $\ldots$ e aspen parkland in the world \\
\hline Sounding Lake and Reflex Lake sand pl & $\begin{array}{l}\text { Kame } \\
\text { sols } \quad \text { sand plain, dune field, non/weak }\end{array}$ \\
\hline Wainwright-David Lake & $\begin{array}{l}\text { h diversity landform as well as rare slope fens, shrub } \\
\text { ens with rart species, active blow-outs }\end{array}$ \\
\hline Neutral Hills-Goosberry Lake & izeable *as of Central Parkland on morainal landscapes \\
\hline Miquelon & the best closed forest in the Cooking Lake Moraine \\
\hline 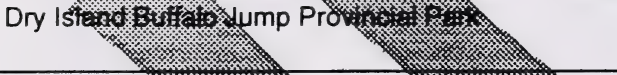 & $\begin{array}{l}\text { Diverse section of Red Deer River Valley including } \\
\text { coniferous forest, badlands and slump block features }\end{array}$ \\
\hline \multicolumn{2}{|l|}{ Mixed Grasshis } \\
\hline Milk River-Logtrits & $\begin{array}{l}\text { last remaining ungrazed vegetation associated with springs } \\
\text { and creeks; numerous plants at northern edge of range; } \\
\text { Mountain Plover breeding habitat }\end{array}$ \\
\hline Midele Sand Hills & $\begin{array}{l}\text { Largest sand dune area in grassland region; numerous rare } \\
\text { or restricted species in excellent condition; landscape of } \\
\text { Canadian significance }\end{array}$ \\
\hline 聯 & $\begin{array}{l}\text { Wide variety of landscape types (including dunes, wetlands, } \\
\text { bedrock outcrops, streams) with attendant wide diversity of } \\
\text { plant communities. }\end{array}$ \\
\hline morgong & $\begin{array}{l}\text { The only active sand dunes in the Grassland region outside } \\
\text { Suffield Military Reserve; habitat for high quality native } \\
\text { vegetation }\end{array}$ \\
\hline McTaggart Coulee and Black Butte & Porphyry with rare lichens \\
\hline Writing-on-Stone Provincial Park & $\begin{array}{l}\text { extensive areas of massive sandstone outcrops with rare } \\
\text { plant and animal species }\end{array}$ \\
\hline Dinosaur Provincial Park & $\begin{array}{l}\text { High variety and quality of badlands and riparian vegetation; } \\
\text { one of the few examples of ungrazed riparian woodland in } \\
\text { the Grassland region }\end{array}$ \\
\hline
\end{tabular}




\section{PART 2}

EXAMPLES OF INDIVIDUALlY NOTEd SIGNIFICANT LANDSCAPES OR PLANT COMMUNITIES IN GRASSLAND, PARKLAND, AND BOREAL REgIONS (WALLIS, 1987; D.A. WESTWORTH \& ASSOCIATES, 1990, BRAMM, 1992: SEE APPENDIX C))

\begin{tabular}{|c|c|}
\hline Location & Feature \\
\hline Terraces along lower Red Deer near Bindloss & $\begin{array}{l}\text { Largest in Grassland Region; nst exter } \\
\text { variety and quality of riparian and diverse } \\
\text { springs with rare }\end{array}$ \\
\hline $\begin{array}{l}\text { South of Empress along the South Saskatchewan } \\
\text { River }\end{array}$ & $\begin{array}{l}\text { Best example hitoba } \mathrm{N} \\
\text { understorey }\end{array}$ \\
\hline Duchess Springs & Most exten e spring wo \\
\hline Douglas Creek adjacent to the Red Deer River & Extensive s of sp seepage veg \\
\hline Northern Fescue Grassland & 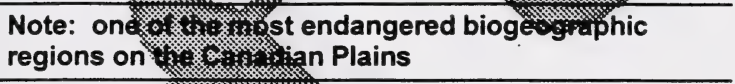 \\
\hline Little Fish-Hand Hills-Wintering Hills area & 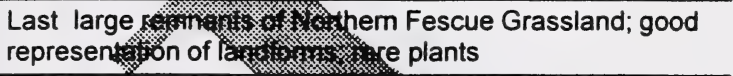 \\
\hline Cypress Hills & 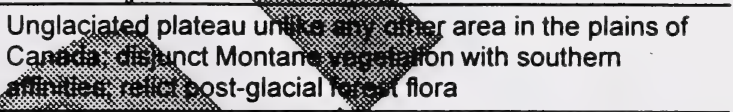 \\
\hline \multirow[t]{2}{*}{ Eastern Boreal Region } & $\begin{array}{l}\text { Many s. } \\
\text { (D.A. identhed for a wide variety of reasons }\end{array}$ \\
\hline & 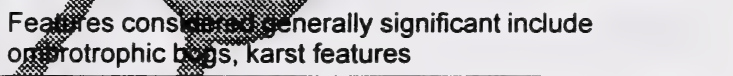 \\
\hline Canadian Shield & $\begin{array}{l}\text { enerally, litto known about significant features in this } \\
\text { gion (Bra 1992) }\end{array}$ \\
\hline Kazan Upland & Tare plant species \\
\hline 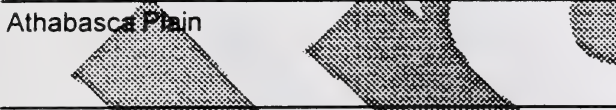 & $\begin{array}{l}\text { Sand dunes among the largest in the world; diverse } \\
\text { found elsewhere in Alberta }\end{array}$ \\
\hline
\end{tabular}




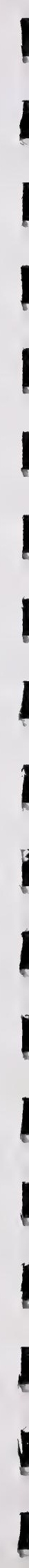




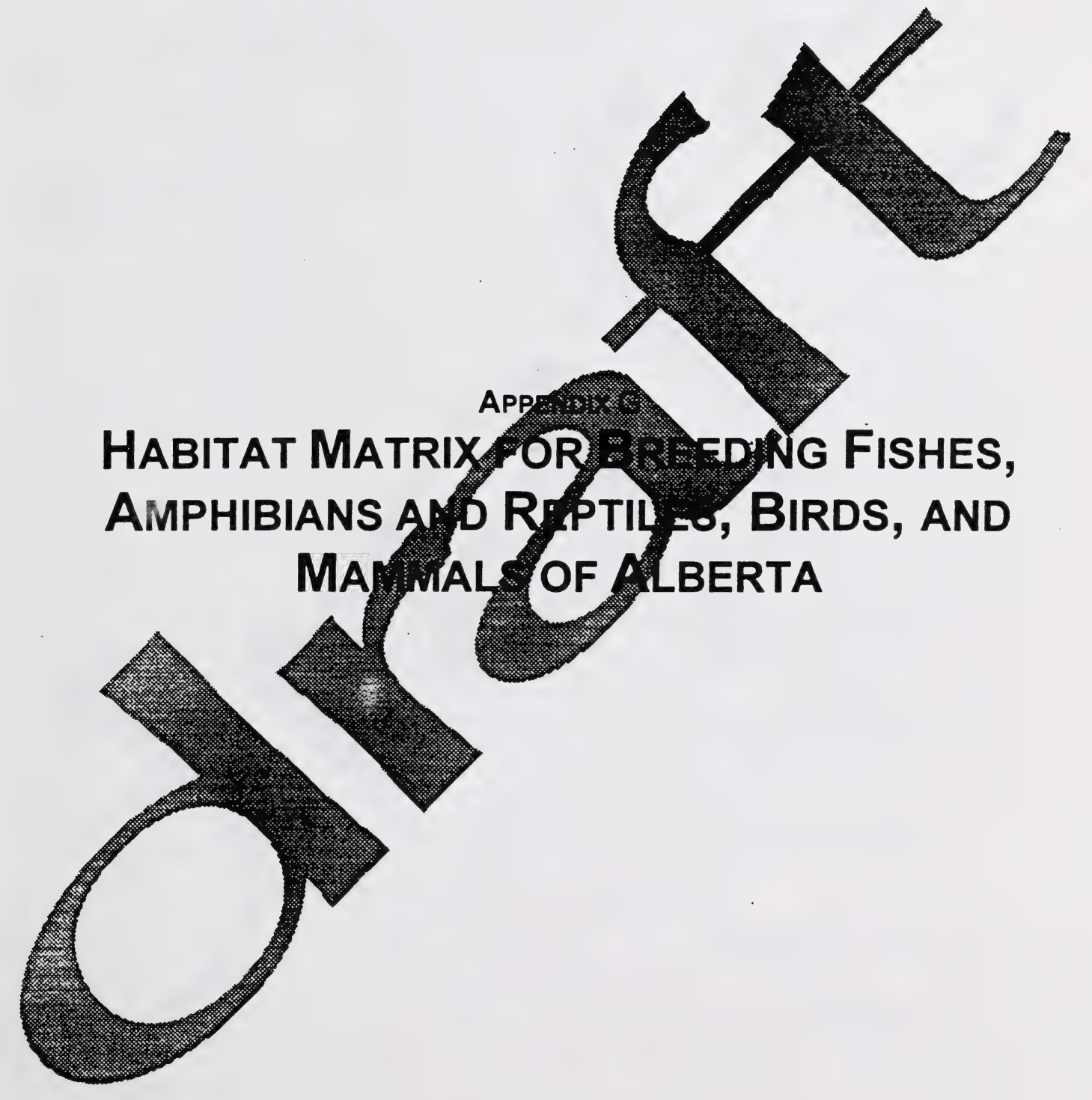




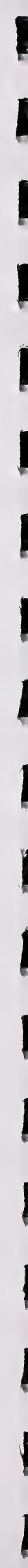




\section{APPENDIX G}

PART 1: HABITAT MATRIX FOR FISHES OF ALBERTA

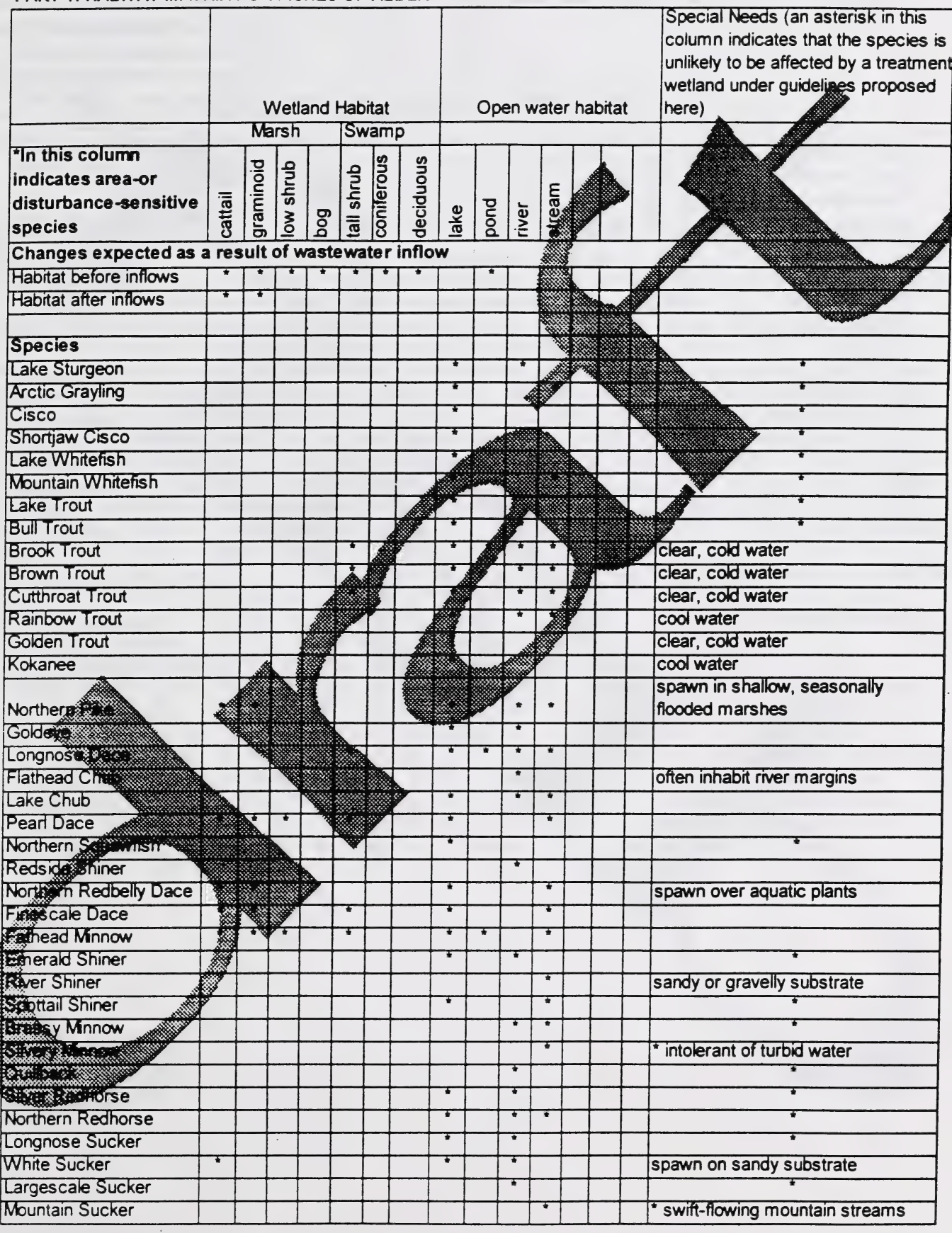


APPENDIX G

PART 1: HABITAT MATRIX FOR FISHES OF ALBERTA

\begin{tabular}{|c|c|c|c|c|c|c|c|c|c|c|}
\hline & \multicolumn{6}{|c|}{ Wetland Habitat } & \multicolumn{3}{|c|}{ Open water habitat } & $\begin{array}{l}\text { Spectal NeedSTan astelsk } \ln \text { mis } \\
\text { column indicates that the species is } \\
\text { unlikely to be affected by a } \\
\text { treatment wetland under guidelines } \\
\text { proposed here) }\end{array}$ \\
\hline & & $\mathrm{Ma}$ & rsh & & Jwan & & & & & \\
\hline $\begin{array}{l}\text { In this column } \\
\text { indicates area-or } \\
\text { disturbance-sensitive } \\
\text { species }\end{array}$ & $\begin{array}{l}\overline{\bar{T}} \\
\text { 荧 }\end{array}$ & 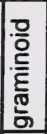 & 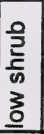 & 8 & 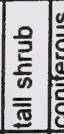 & 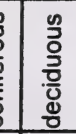 & 产 & $\begin{array}{l}7 \\
\text { 음 }\end{array}$ & & \\
\hline Stonecat & & & & & & & & & & \\
\hline Burbot & & & & & & & & & & \\
\hline Trout-Perch & & & & & & & & & & \\
\hline Brook Stickleback & & & & & 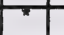 & & & 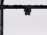 & ] & 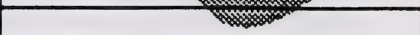 \\
\hline Ninespine Stickleback & & & & & & & & & 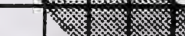 & \\
\hline Towa Darter & & & & & $T$ & & & & & \\
\hline Yellow Perch & & & & & & & & & & \\
\hline Sauger & & & & & & & & & & \\
\hline Walleye & & & & & & & & & & 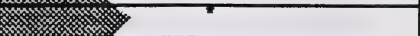 \\
\hline Mottled Sculpin & & & & & & & & & & \\
\hline Slimy Sculpin & & & & & & & & & & \\
\hline Spoonhead Sculpin & & & & & & & & & & \\
\hline
\end{tabular}

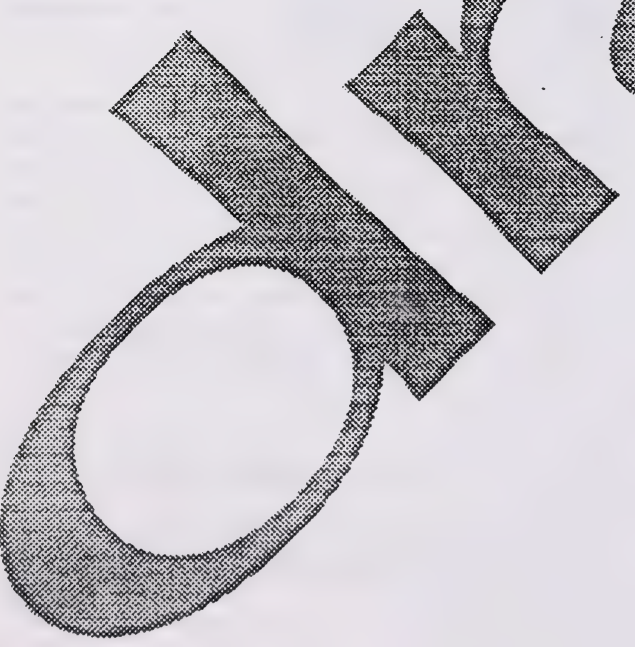


APPENDIX G

PART 2: HABITAT MATRIX FOR BREEDING AMPHIBIANS AND REPTILES

\begin{tabular}{|c|c|c|c|c|c|c|c|c|c|c|c|c|c|c|c|}
\hline & \multicolumn{7}{|c|}{ Lowland Habitat } & \multicolumn{7}{|c|}{ Upland Habitat } & \multirow[t]{2}{*}{ Special Needs } \\
\hline & \multicolumn{4}{|c|}{ Marsh } & \multicolumn{2}{|c|}{ Swamp } & & \multicolumn{2}{|c|}{ Open } & \multicolumn{5}{|c|}{ woodland } & \\
\hline $\begin{array}{l}\text { In this column } \\
\text { indicates area-or } \\
\text { disturbance-sensitive } \\
\text { species }\end{array}$ & $\frac{\overline{\bar{\sigma}}}{\bar{\Xi}}$ & 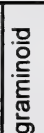 & 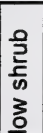 & 잉 & $\begin{array}{l}\frac{0}{3} \\
\frac{5}{\frac{5}{3}} \\
\frac{\bar{\sigma}}{\pi}\end{array}$ & 号 & 옹 & 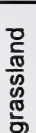 & $\frac{0}{\frac{0}{0}}$ & 올 & 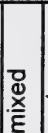 & ڤ & مُ & | & \\
\hline
\end{tabular}

Changes expected as a result of wastewater inflow

Habitat before inflows

Habitat after inflows

Species

Great Plains Toad

Northern Leopard Fro

Wood Frog

Plains Spadefoot Toad

Spotted Frog

Canadian Toad

\begin{tabular}{l|l|l|l|} 
& $\star$ & $\star$ & \\
& $\star$ & $\star$ &
\end{tabular}

Boreal toad

Chorus Frog

g

$+$

Long-toed Salamande

Tiger Salamander

Short-horned Lizard

Western Hognose Snake

Prairie Ratiososake*

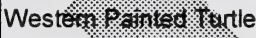

Bull Snakes

Plains Garter 1)

Red-sided Gartê. s.t.

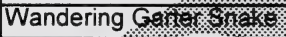

\% oreas in spring fo.

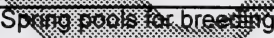

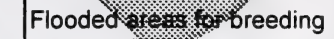

Flooded areas for breeding

Montane areas; flooded

areas for breeding

Water bodies

Flooded areas for breeding

Flooded areas for breeding

Riparian areas in mountains

Concealing cover (debris)

River valley slopes for

hibernation

Permanent standing water

Winter den sites

Generally near water

Permanent water 
APPENDIX G

PART 3: HABITAT MATRIX FOR BREEDING BIRDS OF ALBERTA (information adapted from Semenchuk, 1992)

\begin{tabular}{|c|c|c|c|c|c|c|c|c|c|c|c|c|c|c|c|}
\hline \multirow{3}{*}{$\begin{array}{l}\text { "In this column indicates } \\
\text { area-or disturbance- } \\
\text { sensitive species } \\
\end{array}$} & \multicolumn{7}{|c|}{ Lowland Habitat } & \multicolumn{7}{|c|}{ Upland Habitat } & \multirow{3}{*}{ Special Needs } \\
\hline & \multicolumn{4}{|c|}{ Marsh } & \multicolumn{2}{|c|}{ Swamp } & & \multicolumn{2}{|c|}{ Open } & \multicolumn{5}{|c|}{ Woodand } & \\
\hline & 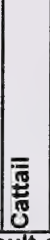 & 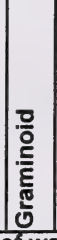 & 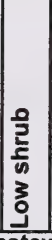 & $\begin{array}{l}8 \\
\\
\end{array}$ & 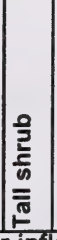 & 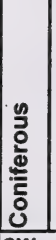 & 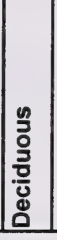 & 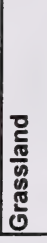 & 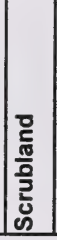 & 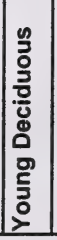 & 总 & 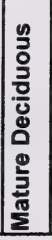 & 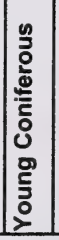 & 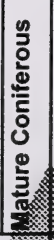 & \\
\hline \multicolumn{15}{|c|}{ Changes expected as a result of wastewater inflow } & \\
\hline Habitat before inflows & * & ${ }^{*}$ & $\star$ & * & $*$ & ${ }^{*}$ & " & $\Rightarrow$ & " & & & & 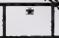 & 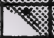 & \\
\hline Habitat after inflows & * & " & & & & & & & & 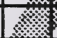 & & & & . & \\
\hline \multicolumn{16}{|l|}{ Species } \\
\hline Red-throated Loon* & $\hbar$ & 7 & & & & & & & & . & & & 糸 & & Deep Wim \\
\hline Pacific Loon* & & & & * & & & & & & (2) & & (3) & & & Northern. \\
\hline Common Loon* & * & * & * & " & & & & & & 留 & & 然 & & & 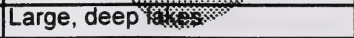 \\
\hline Pied-billed Grebe* & * & 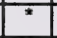 & & 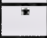 & & & & & & \% & & & 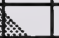 & & Large, deep lakes \\
\hline Horned Grebe & * & * & & & & & & & & 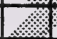 & & & & & Large, marshy lakes \\
\hline Red-necked Grebe ${ }^{*}$ & * & * & & & & & & & & 然 & & & & 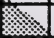 & Colonial: marshy lakes \\
\hline Eared Grebe* & * & $*$ & & & & & & & & & & ry & & & xarge, shallow lakes \\
\hline Western Grebe* & * & * & & & & & & & 丽 & . & & & 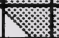 & & al: marshy lakes \\
\hline Clarke's Grebe ${ }^{\star}$ & * & * & & & & & 2 & & & & & & 政 & & onial: marshy lakes \\
\hline American White Pelican ${ }^{\star}$ & $\star$ & * & * & & & & & & & & & & & & $\begin{array}{l}\text { Colonial: on islands in lakes } \\
\text { with fish }\end{array}$ \\
\hline Double-crested Cormorant* & * & * & * & & & & & 次 & & & & & & & $\begin{array}{l}\text { Colonial: on islands in lakes } \\
\text { with fish }\end{array}$ \\
\hline American Bittern" & 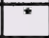 & * & * & ․․ & 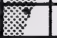 & & & 勧 & & & 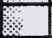 & & & & Tall vegetation \\
\hline Great Blue Heron* & & & & & \$ & 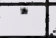 & 丽 & & & & 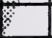 & " & * & & Open marsh nearby \\
\hline Black-crowned Night Heron* & * & * & 乘 & w & * & ${ }^{*}$ & 筮 & & & 悉 & & * & * & & Open marsh nearby \\
\hline White-faced lbis* & & $*$ & & & & . & . & & (3) & 算 & & & & & Mudflats \\
\hline Trumpeter Swan & $*$ & . & 筮 & 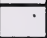 & & \% & & & 梦 & & & & & & Large, marshy lakes \\
\hline Canada Gosis. & 药 & 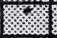 & 稵 & " & & 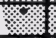 & 举 & \% & & * & & * & * & * & Usually open water \\
\hline Wood fBut : : & & & & & & $\$$ & 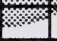 & & & " & & $\bar{z}$ & & & Large dead trees, brood habitat \\
\hline Green-i & & x & & 㑊 & . & & & * & * & & & & & & $\begin{array}{l}\text { Open water nearby, brood } \\
\text { habitat }\end{array}$ \\
\hline Mallard & $x^{*}$ & * & 筮 & x. & $x$ & $y$ & & & & & & & & & $\begin{array}{l}\text { Open water nearby, brood } \\
\text { habitat }\end{array}$ \\
\hline $\begin{array}{c}\text { Northern Pink } \\
\text {. }\end{array}$ & & 死 & & 证 & & & & * & & & & & & & $\begin{array}{l}\text { Open water nearby, brood } \\
\text { habitat }\end{array}$ \\
\hline Blue-siged Teal & & & - & & & & & * & & & & & & & $\begin{array}{l}\text { Open water nearby, brood } \\
\text { habitat }\end{array}$ \\
\hline Mamon Teal & 笞。 & * & & & & & & * & & & & & & & $\begin{array}{l}\text { Open water, brood habitat } \\
\text { nearby }\end{array}$ \\
\hline Korthern Shoveler & & & & & & & & * & & & & & & & $\begin{array}{l}\text { Open water, brood habitat } \\
\text { nearby }\end{array}$ \\
\hline Cartingll & & & & & & & & * & * & & & & & & $\begin{array}{l}\text { Open water, brood habitat } \\
\text { nearby }\end{array}$ \\
\hline Finarican Wogeon* & & & & & & & & * & * & & & & & & Water, brood habitat nearby \\
\hline Carivesback & * & " & & & & & & & & & & & & & Water, brood habitat nearby \\
\hline
\end{tabular}


APPENDIX G

PART 3: HABITAT MATRIX FOR BREEDING BIRDS OF ALBERTA (information adapted from Semenchuk, 1992)

\begin{tabular}{|c|c|c|c|c|c|c|c|c|c|c|c|c|c|c|c|}
\hline \multirow{3}{*}{$\begin{array}{l}\text { \#n this column indicates } \\
\text { area-or disturbance- } \\
\text { sensitive species }\end{array}$} & \multicolumn{7}{|c|}{ Lowland Habitat } & \multicolumn{7}{|c|}{ Upland Habitat } & \multirow{3}{*}{\begin{tabular}{|l} 
Special Needs \\
\end{tabular}} \\
\hline & \multicolumn{4}{|c|}{ Marsh } & \multicolumn{2}{|c|}{ Swamp } & & \multicolumn{2}{|c|}{ Open } & \multicolumn{5}{|c|}{ Woodland } & \\
\hline & 证 & 음 & $\begin{array}{l}0 \\
3 \\
\frac{2}{1} \\
3 \\
0 \\
\end{array}$ & : & $\begin{array}{l}\text { 을 } \\
\frac{1}{5} \\
\frac{\pi}{\sqrt{5}} \\
\end{array}$ & 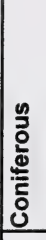 & 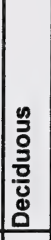 & 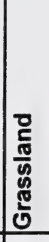 & 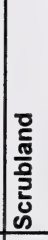 & 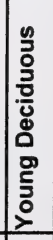 & $\begin{array}{l}\mathbf{g} \\
\underline{\underline{x}} \\
\underline{\underline{\Sigma}} \\
\end{array}$ & 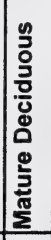 & 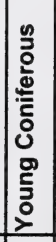 & 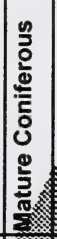 & \\
\hline Redhead & * & * & & & & & & & & & 2 & & & 櫂 & Wlakes \\
\hline Ring-necked Duck & 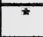 & * & * & * & & & & & & & & 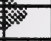 & & 秉 & W \\
\hline Lesser Scaup & & $\bar{x}$ & & & & & & * & & x & 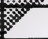 & & & 语 & S glakes \\
\hline Harlequin Duck * & & & & * & * & & & & & x. & & & & 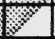 & Fas mams \\
\hline Surf Scoter ${ }^{*}$ & & & & * & F & & & & & 丽 & & & 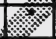 & & 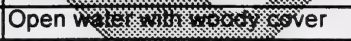 \\
\hline White-winged Scoter ${ }^{*}$ & * & * & * & * & & & & * & * & & . & 2 & & & $\begin{array}{l}\text { Open wate } \\
\text { undisturbed istands }\end{array}$ \\
\hline Common Goldeneye* & & & & & & * & * & & & 桨 & & 菻 & 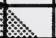 & * & Large dead trees, brood habitat \\
\hline Barrow's Goldeneye ${ }^{\star}$ & & & & & & * & * & & & 3 & $x$ & 戠 & & $\star$ & Large dead trees, brood habitat \\
\hline Bufflehead & & & & & & * & * & & 3 & . & & $x$ & & $x$ & Large dead trees, brood habitat \\
\hline Hooded Merganser & & & & & & $=$ & * & & & 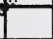 & & 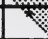 & & 筑 & arge dead trees, deep water \\
\hline Common Merganser & & & & & & \# & 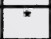 & 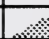 & & 絧 & & 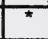 & x. & 呈 & Carge dead trees, deep water \\
\hline Red-breasted Merganser ${ }^{*}$ & & & & & & & 器 & & & 簽 & 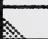 & 7 & $*$ & x & Shorelines, deep water \\
\hline Ruddy Duck & * & * & * & & & & m & $\ldots$ & x. & 乘 & x. & - & & 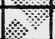 & Open water, brood habitat \\
\hline Turkey Vulture* & & & & & & \% & & & . & . & x. & . & 3 & & Rocky outcrops, near water \\
\hline Osprey* & * & $\bar{t}$ & * & & 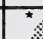 & 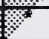 & 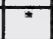 & ${ }^{\star} 3$ & 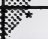 & (1) & 要 & $x$ & 事 & 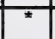 & Tall structures, near fish \\
\hline Bald Eagle* & & & & & 3 & & & 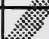 & & & 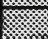 & 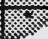 & & $\star$ & Tall structures, near fish \\
\hline Northern Harrier ${ }^{*}$ & ${ }^{*}$ & ॠ & & 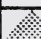 & w & & & 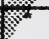 & * & & 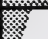 & 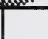 & & & Open country \\
\hline Sharp-shinned Hawk & & & & & 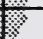 & & 的 & & & 8 & 落 & 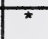 & & * & \\
\hline Cooper's Hawk ${ }^{*}$ & & & 器 & $\%$ & & & 亦 & & & 济 & $\star$ & $\div$ & & * & Often near water \\
\hline Northern Goshawk* & & & $\sqrt{1}$ & & & 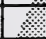 & & & 桨 & 事 & * & * & & * & \\
\hline Broad-winged Hawk* & & 紘. & & & & 亦 & & & \% & & " & * & & * & \\
\hline Swainson's sk & & & & & & & & 梦 & $*$ & & & & & & Tall trees \\
\hline Red-tainorgramo & & & & & & & 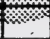 & * & * & * & * & * & \# & * & Open country nearby \\
\hline Ferruginous w & & & & x & & & & * & & & & & & & Sparsely treed areas \\
\hline Golden Eağ/ & & 策 & 将 & & \% & 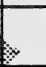 & & * & & & & & & & $\begin{array}{l}\text { Sparsely treed areas, slopes or } \\
\text { plateaus }\end{array}$ \\
\hline American Kestrel| & 鵕 & & & & \% & & & * & * & * & $*$ & * & * & $*$ & $\begin{array}{l}\text { Open country nearby, nest } \\
\text { cavities }\end{array}$ \\
\hline Merlin & & 格 & & 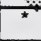 & & * & & & * & * & * & * & $\hbar$ & * & Open country nearby \\
\hline Peregralco Falcon* & & & . & & & & & 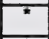 & * & & & & & & Cliffs \\
\hline Praifis Falcon* & & & 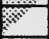 & & & & & * & * & & & & & & Cliffs \\
\hline Gify Partridge & & 森 & & & & & & * & ${ }^{*}$ & & & & & & Adjacent woods \\
\hline 3ilg-necked Pheasant & 管 & & & & & & & " & * & * & & & * & & \\
\hline Spruce Grouse & & & & * & & & & & & & * & & * & * & \\
\hline bilue Grouse" & & & & & & & & & & & * & & * & * & Mountains \\
\hline Xefow Ptarmigan" & & & * & * & * & & & & & & & & & & Above timberline \\
\hline 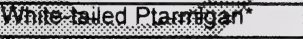 & & & & & & & & * & & & & & & & Alpine meadows \\
\hline Wifor Srouso & & & & & & & & & & & * & * & & & Small openings \\
\hline ge G & & & & & & & & & * & & & & & & $\begin{array}{l}\text { Sagebrush, dense river } \\
\text { bottoms }\end{array}$ \\
\hline
\end{tabular}


APPENDIX G

PART 3: HABITAT MATRIX FOR BREEDING BIRDS OF ALBERTA (information adapted from Semenchuk, 1992)

\begin{tabular}{|c|c|c|c|c|c|c|c|c|c|c|c|c|c|c|c|}
\hline \multirow{3}{*}{\begin{tabular}{|l|} 
\\
"In this column indicates \\
area-or disturbance- \\
sensitive species
\end{tabular}} & \multicolumn{7}{|c|}{ Lowland Habitat } & \multicolumn{7}{|c|}{ Upland Habitat } & \multirow{3}{*}{ Special Needs } \\
\hline & \multicolumn{4}{|c|}{ Marsh } & \multicolumn{2}{|c|}{ Swamp } & & \multicolumn{2}{|c|}{ Open } & \multicolumn{5}{|c|}{ Woodland } & \\
\hline & 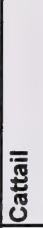 & 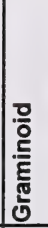 & $\begin{array}{l}\text { 올 } \\
\frac{1}{5} \\
3 \\
0 \\
0\end{array}$ & $\begin{array}{l}\text { : } \\
\text { m } \\
\end{array}$ & 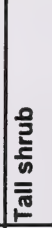 & 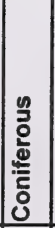 & 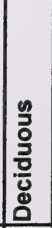 & 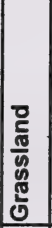 & 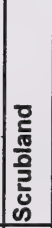 & 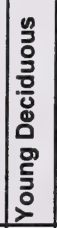 & 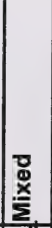 & 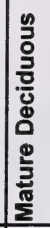 & 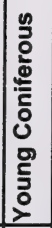 & 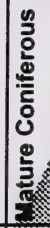 & \\
\hline Sharp-tailed Grouse & & & & ${ }^{*}$ & & & & ${ }^{*}$ & & & & & & & \\
\hline Wild Turkey & & & & & & & & & & ${ }^{*}$ & & $\%$ & & 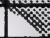 & Fin to Alberta \\
\hline Yellow Rail* & & 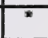 & & & & & & & & 2 & 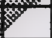 & & & 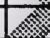 & m \\
\hline Virginia Rail & 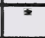 & * & & & & & & & & 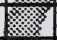 & & & 2 & 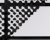 & \\
\hline Sora & $\div$ & " & " & & & & & & & . & & & 壮 & & \\
\hline American Coot & * & * & & & & & & & & & 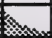 & & & & Open wates \\
\hline Sandhill Crane* & " & 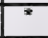 & & \# & & & & & & x & & & & & $\ldots$ \\
\hline Whooping Crane* & ॠ & $=$ & & & & & & & & x & & & 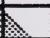 & & \\
\hline Semipalmated Plover" & & & & & & & & & & 2 & & & & & Sand, gravel shores \\
\hline Piping Plover" & & & & & & & & & & 梦 & & & & xis & Sandy shores of saline lakes \\
\hline Killdeer & & & & & & & & & & & & 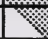 & 留 & & Gand and gravel \\
\hline Mountain Plover" & & & & & & & & $*$ & 森 & 校 & & & 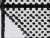 & & grassland \\
\hline Black-necked Stilt* & & * & & & & & 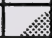 & & & & & & 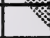 & & 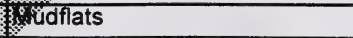 \\
\hline American Avocet ${ }^{*}$ & & \# & & & & & & 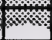 & & & 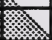 & & & 事 & Mudflats \\
\hline Greater Yellowlegs* & & & " & * & 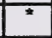 & 2 & & & 烈 & & & . & 을 & $\infty$ & \\
\hline Lesser Yellowlegs* & & & & ॠ & 绿 & 悉 & & 桖 & 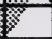 & 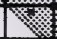 & 梦 & 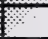 & * & & Water, brood habitat \\
\hline Solitary Sandpiper ${ }^{*}$ & & & & & 慈 & * & & 幽 & & & X & & & & \\
\hline Willet & & * & & 3x & 縵 & & 2 & 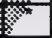 & & & 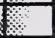 & & & & Water \\
\hline Spotted Sandpiper & $*$ & * & $*$ & m. & 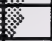 & & 䌤 & & & 变 & 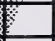 & & & & \\
\hline Upland Sandpiper ${ }^{*}$ & & * & 筮 & 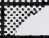 & & & x & $*$ & & 紊 & & & & & \\
\hline Long-billed Curlew* & & & & & & 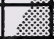 & . & * & 敪 & 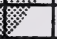 & & & & & Brood habitat \\
\hline Marbled Godwit ${ }^{*}$ & & x & 絁 & & & 然 & & 展 & 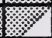 & & & & & & Low grass, water \\
\hline Least Saptigher" & & 筮 & 筮 & * & & x. & & 㕰 & & & & & & & \\
\hline Short-billeg os ow & & 粟 & & * & & 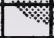 & m & & & & & & & & Low vegetation \\
\hline Commor & 然 & 桨 & 梦 & $x$ &. & & & & & & & & & & Open areas nearby \\
\hline 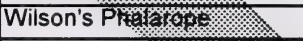 & & 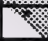 & & 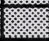 & . & & & & & & & & & & Open water \\
\hline 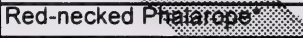 & & $\bar{*}$ & 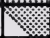 & 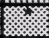 & & 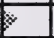 & & & & & & & & & Open water \\
\hline Franklin's Gull*, & 垔 & & & & 烈 & & & & & & & & & & Open water \\
\hline 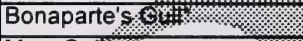 & & 玹 & & 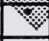 & & * & & & & & & & * & * & Open water \\
\hline Mew Gu潾 & x.s. & & 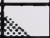 & & & & & & & & & & & & Open water \\
\hline 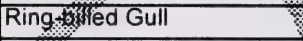 & & & 稵 & & & & & & & & & & & & Islands, open water \\
\hline Calfiórnia Gull & 筮 & & & & & & & & & & & & & & Rocky islands in lakes \\
\hline ring Gull & 䇾 & 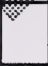 & & & & & & & & & & & & & Rocky islands in lakes; colonial \\
\hline Caspian Tern & & & & & & & & & & & & & & & Rocky islands in lakes \\
\hline Smmon Tern & & & & & & & & & & & & & & & Sandy shores of lakes \\
\hline rotster's Tern* & * & & & & & & & & & & & & & & \\
\hline 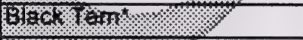 & " & 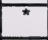 & & & & & & & & & & & & & \\
\hline poof 5 rove : & & & & & & & & & & & & & & & Nests in human structures \\
\hline 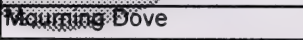 & & & & & & & & * & * & & * & & * & \# & Often near water \\
\hline
\end{tabular}




\section{APPENDIX G}

PART 3: HABITAT MATRIX FOR BREEDING BIRDS OF ALBERTA (information adapted from Semenchuk, 1992)

\begin{tabular}{|c|c|c|c|c|c|c|c|c|c|c|c|c|c|c|c|}
\hline \multirow{3}{*}{\begin{tabular}{|l|} 
"In this column indicates \\
area-or disturbance- \\
sensitive species
\end{tabular}} & \multicolumn{7}{|c|}{ Lowland Habitat } & \multicolumn{7}{|c|}{ Upland Habitat } & \multirow{3}{*}{ Special Needs } \\
\hline & \multicolumn{4}{|c|}{ Marsh } & \multicolumn{2}{|c|}{ Twamp } & & \multicolumn{2}{|c|}{ Open } & \multicolumn{5}{|c|}{ Woodland } & \\
\hline & 焉 & 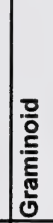 & \begin{tabular}{l}
0 \\
\multirow{2}{2}{} \\
$\frac{2}{4}$ \\
3 \\
0 \\
\end{tabular} & ஜூ: & 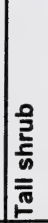 & 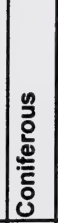 & 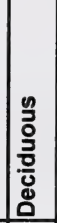 & 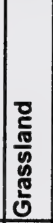 & 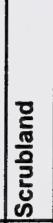 & 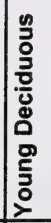 & 曽 & 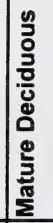 & 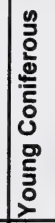 & 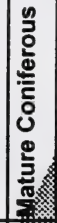 & \\
\hline Black-billed Cuckoo & & & & & & & & & & & 2 & & & $\ldots$ & nderbrush \\
\hline Great Horned Owl & & & & & & \% & * & & & * & & 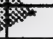 & * & 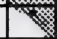 & \\
\hline Northern Hawk Owl* & & & & & & $*$ & & & & 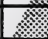 & 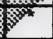 & & & . & \\
\hline Northern Pigmy Owl & & & & & & & & & & 洨 & * & & & 䢣 & Adj z W y \\
\hline Burrowing Owl* & & & & & & & & $\star$ & & x & & & 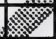 & & \\
\hline Barred Ow|* & & & & & & & & & & & 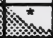 & 2 & & $*$ & Nest cavitiogs \\
\hline Great Gray Owl* & & & & & & & & & & & & 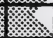 & & * & \\
\hline Long-eared Ow! & & & & & & & & & & 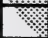 & 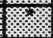 & $x$ & a & + & Near water \\
\hline Short-eared Owl* & & & & & & & & * & & 2 & 然 & & & 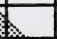 & \\
\hline Boreal Owl & & & & & & & & & 妾 & 唡 & & & & x. & \\
\hline Northern Saw-whet owl & & & & & & & & & & & * & * & & 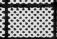 & Syst cavities \\
\hline Common Nighthawk & & & & & & & & ${ }^{*}$ & & 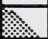 & & & 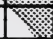 & & 3. \\
\hline Black Swift* $^{*}$ & & & & & & & 2 & & & & 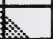 & & & 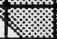 & Sontane cliffs near waterfalls \\
\hline Ruby-throated Hummingbird & & & & & & & 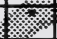 & 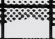 & & 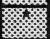 & 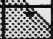 & $*$ & & 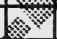 & Open woodlands \\
\hline Calliope Hummingbird* & & & & & * & 紋 & & & 然 & 系 & $x$ & 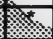 & 7 & $8 *$ & Open montane woodlands \\
\hline Rufous Hummingbird & & & & & & * & * & & & 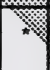 & 森 & x. & . & * & $\begin{array}{l}\text { Adjacent to openings with } \\
\text { flowers }\end{array}$ \\
\hline Belted Kingfisher & & & & …… & 柆 & & 紊 & 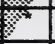 & 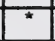 & * & 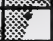 & * & * & * & Burrows near water \\
\hline Yellow-bellied Sapsucker & & & & & 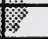 & & 秝 & & & 2 & * & * & & & Nest cavities near openings \\
\hline Red-naped Sapsucker & & & & 棌 & & & 乘 & & & 我 & * & * & & & Nest cavities \\
\hline Downy woodpecker & & & & & & 疗 & 原 & & 2. & \% & * & * & 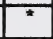 & & Nest cavities \\
\hline Hairy Woodpecker" & & 䋞 & & & & 筮 & mas & & 将 & * & * & ${ }^{\star}$ & * & * & Nest cavities \\
\hline 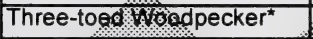 & 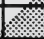 & & & & & 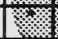 & & 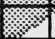 & & & * & & & $\star$ & Nearby openings; nest cvities \\
\hline 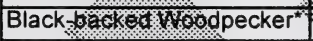 & & & & & & $+\infty$ & 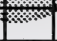 & & & & * & & & t & Dense forest; nest cavities \\
\hline 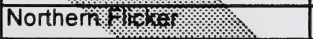 & & & & 的 & & * & $=$ & & & & * & 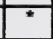 & & $*$ & Nest cavities \\
\hline Pileated Wow & & (x) & & & 就 & & $\div$ & & & & \# & 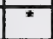 & & & Nest cavities \\
\hline Olive-sided Fly asly & & & 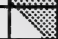 & 䇥 & & $x^{*}$ & & & & & 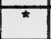 & & * & * & Semi-open forest near water \\
\hline Western Wood-R hy he h & & & & & 幽 & " & ${ }^{*}$ & & & " & $\star$ & * & * & " & \\
\hline Yellow-belliefs & & 焚 & & 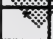 & & * & * & & & & & & * & 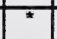 & \\
\hline Alder Flyeglatcher & & & 桨 & & * & & & & * & & & & & & Near water \\
\hline Willow lycatcher & & & $x$ & & " & & & & * & & & & & & Usually near water \\
\hline Lexist Flycatcher & & & & & & * & $\bar{\star}$ & & & * & * & * & * & * & Open woodland \\
\hline Xisimmond's Flycatcher ${ }^{*}$ & 栓 & & & & & & & & & & & & * & * & \\
\hline U. Sky Flycatcher & z & & & & $*$ & & & & * & * & * & & & & Open woodland \\
\hline Wordilleran Flycatcher & & & & & & * & * & & & & * & * & * & * & Open woodland \\
\hline Wastern Phoebe & & & & & & * & * & & & * & * & * & * & * & Structures near water \\
\hline soy fophoebe & & & & & & & & " & * & & & & & & Sheltered area with overhang \\
\hline 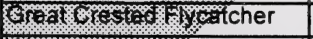 & & & & & & & & & & & * & * & & & Nest cavities \\
\hline 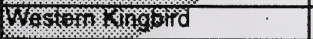 & & & & & & & & * & & & & & & & Tall perches \\
\hline Easterin Kingbird & & 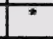 & * & * & $\div$ & & & 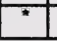 & * & & & & & & Tall perches, openings \\
\hline
\end{tabular}


APPENDIX G

PART 3: HABITAT MATRIX FOR BREEDING BIRDS OF ALBERTA (information adapted from Semenchuk, 1992)

\begin{tabular}{|c|c|c|c|c|c|c|c|c|c|c|c|c|c|c|c|}
\hline \multirow{3}{*}{$\begin{array}{l} \\
\text { "In this column indicates } \\
\text { area-or disturbance- } \\
\text { sensitive species }\end{array}$} & \multicolumn{7}{|c|}{ Lowland Habitat } & \multicolumn{7}{|c|}{ Upland Habitat } & \multirow{3}{*}{ Special Needs } \\
\hline & \multicolumn{4}{|c|}{ Marsh } & \multicolumn{2}{|c|}{ Swamp } & & \multicolumn{2}{|c|}{ Open } & \multicolumn{5}{|c|}{ Woodand } & \\
\hline & 䙲 & 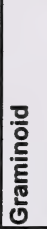 & 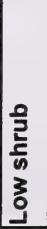 & : & $\begin{array}{l}\frac{0}{2} \\
\frac{2}{5} \\
\frac{0}{\pi} \\
\frac{\pi}{5}\end{array}$ & ơ & & 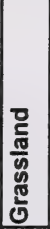 & 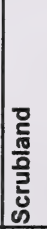 & 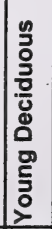 & 惫 & 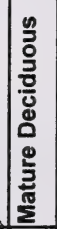 & 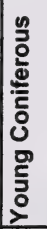 & 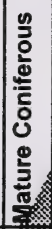 & \\
\hline Horned Lark & & & & & & & & $\div$ & $*$ & * & $\ldots$ & 4 & & 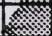 & Kound \\
\hline Purple Martin & & & & & & * & 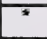 & & & & 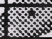 & 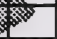 & & 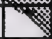 & en areas \\
\hline Tree Swallow & & & & * & * & * & * & & & 伭 & 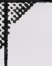 & * & & 4 & adjar \\
\hline Violet-green Swallow & & & * & * & * & * & * & & & & & & & & $\begin{array}{l}\text { Nest cat } \\
\text { openings }\end{array}$ \\
\hline $\begin{array}{l}\text { Northern Rough-winged } \\
\text { Swallow }\end{array}$ & & $*$ & * & & & & & * & & & & & & & $\begin{array}{l}\text { Banks and openswand near } \\
\text { water }\end{array}$ \\
\hline Bank Swallow & & & & & & & & * & * & 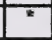 & 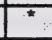 & & 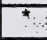 & & Banks near water \\
\hline Cliff Swallow & & & & & & & & * & * & * & * & & 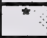 & & Cliffs near water \\
\hline Barn Swallow & * & * & * & * & & & & * & * & & & & & & Structures near water \\
\hline Gray Jay* & & & & " & & * & & & & & * & & * & * & Dense Forests \\
\hline Steller's Jay & & & & & & & & & & & & & & * & $\begin{array}{l}\text { Montane and lower subalpine } \\
\text { regions }\end{array}$ \\
\hline Blue Jay & & & & & & 糸 & & & & & 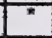 & * & & & \\
\hline Clarke's Nutcracker & & & & & 2 & 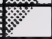 & & . & 8 & & 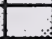 & . & 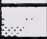 & * & Openings \\
\hline Black-billed Magpie & & & & & 2. & & & 将 & 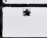 & $*$ & 然 & 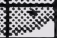 & * & & Nest trees \\
\hline American Crow & & & & 筮 & 悉 & * & * & 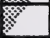 & * & * & 票 & 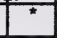 & * & $\div$ & \\
\hline Common Raven ${ }^{\star}$ & & & & & 梦 & * & 悉 & & & & $x^{*}$ & & & $\div$ & \\
\hline Black-capped Chickadee & & & 栗 & 禁 & + & ${ }^{*} 3$ & 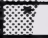 & & " & 縗 & $*$ & * & * & 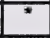 & Nest cavities \\
\hline Mountain Chickadee ${ }^{*}$ & & & & & & r.x. & m. & & 获 & 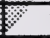 & * & & & " & Nest cavities; open woods \\
\hline Boreal Chickgdee & & 高 & 䇣 & * & & 筮 & m. & & 曻 & & * & & * & * & \\
\hline Red-breasing & & & & & & W. & & \% & & & * & & & $\bar{\pi}$ & \\
\hline 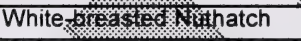 & & & & 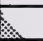 & & 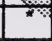 & 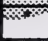 & & & & * & * & & * & \\
\hline Brown ct. . . . & & & & & & 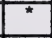 & & & & & * & & & " & \\
\hline Rock Wren & & & 留 & & 紧 & 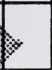 & & * & & & & & & & $\begin{array}{l}\text { Areas with sparse vegetation; } \\
\text { rock outcrops }\end{array}$ \\
\hline House Wren & & & & 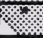 & 器 & & & & * & * & & & * & & Nest cavities \\
\hline Winter Wreg & & 率 & & w & & * & & & & & * & & & * & \\
\hline Sedge Wxocen & & 签 & . & $*$ & * & & & * & * & & & & & & Near water \\
\hline Marst䇣Uren* & 筮 & 筮 & $\ldots$ & & & & & & & & & & & & \\
\hline Akig gican Dipper ${ }^{\star}$ & & & & & & & & & & & & * & & * & Rock ledges over flowing water \\
\hline G⿰氵 & & & & & & * & & & & & 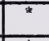 & & & 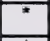 & \\
\hline Winglet & & & & & & * & & & & & * & & & * & \\
\hline wstern Bluebird & & & & & & & & 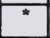 & * & * & & & * & & Nest cavities \\
\hline Western Bluebird* & & & & & & & 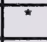 & & * & & & & & & Snags; sparse tree cover \\
\hline Woungain Bluebird & & & & & & & " & & & * & & " & * & & Nest cavities, openings \\
\hline 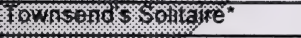 & & & & & & & & & & & & & & $\overline{7}$ & Mountains and foothills \\
\hline teen .1. & & & & & & & " & & & * & " & " & & & Shrubby understory \\
\hline Swaintson's Thrush* & & & & & & & $*$ & & & & & & & * & \\
\hline
\end{tabular}




\section{APPENDIX G}

PART 3: HABITAT MATRIX FOR BREEDING BIRDS OF ALBERTA (information adapted from Semenchuk, 1992)

\begin{tabular}{|c|c|c|c|c|c|c|c|c|c|c|c|c|c|c|c|}
\hline \multirow{3}{*}{\begin{tabular}{|l|} 
\\
"In this column indicates \\
area-or disturbance- \\
sensitive species
\end{tabular}} & \multicolumn{7}{|c|}{ Lowland Habitat } & \multicolumn{7}{|c|}{ Upland Habitat } & \multirow{3}{*}{\begin{tabular}{|l|} 
Special Needs \\
\end{tabular}} \\
\hline & \multicolumn{4}{|c|}{ Marsh } & \multicolumn{2}{|c|}{ Tswamp } & & \multicolumn{2}{|c|}{ Open } & \multicolumn{5}{|c|}{ Woodland } & \\
\hline & 焉 & 흥 & $\begin{array}{l}0 \\
\frac{2}{2} \\
\frac{1}{5} \\
3 \\
0 \\
9\end{array}$ & : & $\frac{0}{\frac{0}{2}}$ & : & 올 & 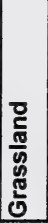 & 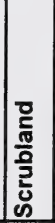 & 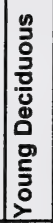 & 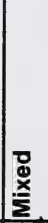 & 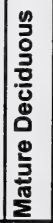 & 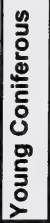 & 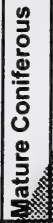 & \\
\hline \multicolumn{16}{|l|}{ Hermit Thrush* } \\
\hline \multicolumn{16}{|l|}{ American Robin } \\
\hline \multirow{2}{*}{\multicolumn{16}{|c|}{ W }} \\
\hline & & & & & * & & & & * & 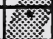 & & & * & 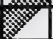 & W \\
\hline \multicolumn{16}{|l|}{ Northern Mockingbird } \\
\hline Sage Thrasher ${ }^{*}$ & & & & & & & & * & & . & 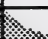 & 丞 & 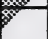 & 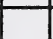 & Sagebrush \\
\hline \multicolumn{16}{|l|}{ Brown Thrasher } \\
\hline American Pipit* & & & $=$ & & & & & * & & $x$ & & & a & & Above timberline \\
\hline \multicolumn{16}{|l|}{ Sprague's Pipit ${ }^{*}$} \\
\hline Bohemian Waxwing ${ }^{*}$ & & & & & & & & & & 留 & \# & & m. & 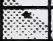 & Openings \\
\hline \multicolumn{16}{|l|}{ Cedar Waxwing } \\
\hline Northern Shrike ${ }^{*}$ & & & & * & & 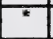 & & 悉 & $5 x$ & a & & & 桨 & 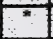 & Open woods \\
\hline Loggerhead Shrike ${ }^{*}$ & & & & & 7 & & 2 & & 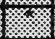 & m. & 2 & & & 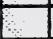 & Thorn bushes \\
\hline European Starling & & & & & & & $x$ & 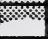 & 校 & 筮 & 筮 & * & & 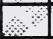 & Cavities; highly adaptable \\
\hline \multicolumn{16}{|l|}{ Solitary Vireo* } \\
\hline \multicolumn{16}{|l|}{ Warbling Vireo } \\
\hline \multicolumn{16}{|l|}{ Philadelphia Vireo" } \\
\hline \multicolumn{16}{|l|}{ Red-eyed Vireo } \\
\hline \multicolumn{16}{|l|}{ Tennessee Warbler* } \\
\hline \multicolumn{16}{|l|}{ Orange-crowned Warbler ${ }^{*}$} \\
\hline Nashville Warbler & & & & $*$ & & 筮 & x & & 㓎 & 㡅 & * & & * & & \\
\hline Yellow Warbler & & 網. & 幽 & & * & r. & & & 皮 & * & * & & * & & \\
\hline Chestnut-shorbler & 2 & & & & * & 絲 & & & 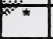 & * & 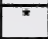 & & * & & \\
\hline Magno:hy & & & . & 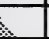 & & F & $\ldots$ & & * & & * & & * & & \\
\hline Cape Mras & & & & x. & & & & & & & * & & & 7 & Tall song perches \\
\hline Yellow-rumb4) & & & & 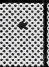 & a & 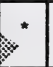 & & & & & & & & * & $\begin{array}{l}\text { Some deciduous trees; open } \\
\text { woods }\end{array}$ \\
\hline Townsend's Warbis & & & & & 带 & $x^{*}$ & & & & & & & & * & Dense canopy, water nearby \\
\hline $\begin{array}{l}\text { Black-throater } \\
\text { Warbler }\end{array}$ & & 侳 & & & & * & & & & & * & & & * & \\
\hline Black & & & . & & & & & & & & $\div$ & & & 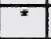 & \\
\hline Paffịtharbler & & & $*$ & * & * & * & * & & & & & & & & \\
\hline Eveasted Warbler* & 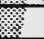 & \% & & & & * & & & & & & & * & * & \\
\hline S8: 8 ckpoll Warbler* & & & & & & * & & & * & & * & & & * & \\
\hline 5. ck-and-white Warbler* & & & & * & * & ${ }^{*}$ & & & & & $*$ & * & & & \\
\hline resican Redstart & & & & & * & & * & & & * & $*$ & * & & & \\
\hline W & & & & & & & & & & & $*$ & * & & & Sparse understory \\
\hline 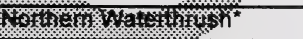 & & & & & $*$ & & $*$ & & & & 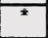 & * & & & Near water \\
\hline 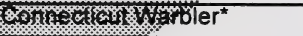 & & & & * & & & & & & & * & * & & & Sparse understorey \\
\hline
\end{tabular}




\section{APPENDIX G}

PART 3: HABITAT MATRIX FOR BREEDING BIRDS OF ALBERTA (information adapted from Semenchuk, 1992)

\begin{tabular}{|c|c|c|c|c|c|c|c|c|c|c|c|c|c|c|c|c|}
\hline \multirow{3}{*}{\begin{tabular}{|l} 
\\
"In this column indicates \\
area-or disturbance- \\
sensitive species
\end{tabular}} & \multicolumn{7}{|c|}{ Lowland Habitat } & \multicolumn{8}{|c|}{ Upland Habitat } & \multirow{3}{*}{ Special Needs } \\
\hline & \multicolumn{4}{|c|}{ Marsh } & \multicolumn{3}{|c|}{ Swamp } & \multicolumn{3}{|c|}{ Open } & \multicolumn{5}{|c|}{ Woodand } & \\
\hline & 言 & $\begin{array}{l}\text { 흥 } \\
\text { 을 } \\
\text { 들 } \\
\end{array}$ & $\begin{array}{l}0 \\
\frac{3}{2} \\
\frac{1}{4} \\
3 \\
3 \\
0\end{array}$ & ర్ల & 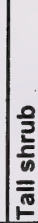 & 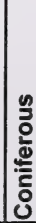 & $\frac{0}{0}$ & & & 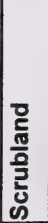 & 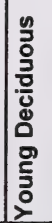 & 总 & 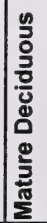 & 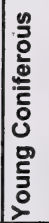 & 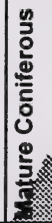 & \\
\hline Mourning Warbler & & & * & & * & & & & & & & . & * & & & Wan \\
\hline MacGillivray's Warbler" & & & & & * & & & & & * & w & \% & & & 2) & Mposy \\
\hline Common Yellowthroat & * & & * & 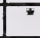 & * & & & & & & 桨 & & & . & 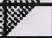 & W \\
\hline Wilson's Warbler ${ }^{*}$ & & & & & * & & - & & & ${ }^{\star}$ & $x$ & & & 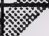 & & Near w \\
\hline Canada Warbler* & & & & & * & & 7 & & & & . & ${ }^{*}$ & 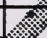 & & & Near wate \\
\hline Yellow-breasted Chat & & & & & * & & & & & $\star *$ & 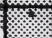 & & 筮 & & & 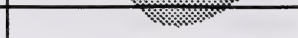 \\
\hline Western Tanager ${ }^{\star}$ & & & & & & & & & & & 悉 & 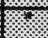 & $x$ & 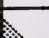 & $*$ & Open woodlands \\
\hline Rose-breasted Grosbeak & & & & & & & & & & & x. & x. & 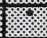 & & & \\
\hline Black-headed Grosbeak & & & & & & & & & & 落 & s & wa & 悉 & & a & \\
\hline Lazuli Bunting & & & & & * & & & & & 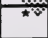 & $\star$ & & 策 & & & ense undergrowth \\
\hline Rufous-sided Towhee & & & & & * & & & & 新 & 桨 & ${ }^{*}$ & & & 校 & 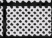 & s. \\
\hline American Tree Sparrow* & & & * & & 7 & & 3 & & & & $8 \times$ & & & $-\infty$ & 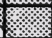 & 梨 \\
\hline Chipping Sparrow & & & & & & & & & 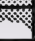 & 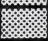 & 簽 & 率 & & * & \% & \\
\hline Clay-coloured Sparrow & & & * & * & & seme & & & * & 簽 & \% & & : & 皮 & & \\
\hline Brewer's Sparrow" & & & & & 8 & s & & & 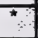 & $\star$ & . & & & 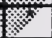 & & Sagebrush \\
\hline Vesper Sparrow & & & & & 纹 & & & & 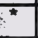 & & & & & & & \\
\hline Lark Sparrow* & & & & 落 & 桨 & & & & * & * & & & & & & \\
\hline Lark Bunting* & & & 3 & & 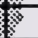 & & 缡 & & * & & 3 & & & & & \\
\hline Savannah Sparrow & & * & 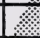 & 幽 & & & & & * & * & w & & & & & \\
\hline \begin{tabular}{|c|} 
Baird's Sparrow* \\
\end{tabular} & & . & 梦 & & & 5 & & & $*$ & 格 & 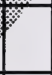 & & & & & $\begin{array}{l}\text { Abundant matted grasses; } \\
\text { intolerant of grazing }\end{array}$ \\
\hline Grasshopostogarrow* & & & 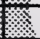 & & & & & & 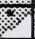 & & & & & & & \\
\hline 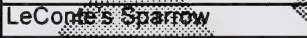 & & 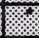 & x & * & & 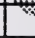 & & & & & & & & & & \\
\hline Sharp-tuked sparrox & & 烈 & & 椾 & & & & & & & & & & & & \\
\hline Fox Sparrór & & 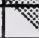 & & & * & & & & & * & & & & * & & \\
\hline Song Sparrow & & & w & 筮 & 番 & $y^{*}$ & - & & & 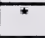 & * & * & * & * & * & \\
\hline Lincoln's Sparroy & . & & + & $x$ & $\%$ & & & & & & & & & & & \\
\hline Swamp Spariow & 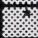 & 慈 & * & 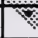 & 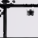 & & & & & & & & & & & \\
\hline White-throsted Sparrow & & & 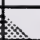 & * & * & F & & & & * & & * & & * & & \\
\hline Golderowned Sparrow & & & m & & & & & & & " & & & & * & & Montane habitats \\
\hline Wleine-crowned Sparrow" & m & & & * & " & & & & & * & & & & * & & \\
\hline Hón-eyed Junco & 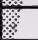 & 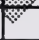 & & * & * & * & & & & $*$ & & 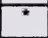 & & & * & \\
\hline W'Cown's Longspur" & & & & & & & & & * & & & & & & & Short grass \\
\hline $\begin{array}{l}\text { Whestnut-collared } \\
\text { koggspur* }\end{array}$ & & & & & & & & & * & & & & & & & \\
\hline Boboljnk & & & & & & & & & * & & & & & & & \\
\hline Ked ritiged Black kird & * & * & * & * & * & & & & & & & & & & & \\
\hline Westerm Meadowlark" & & & & & & & & & * & $*$ & & & & & & \\
\hline W wed Blackbird & * & & & & & & & & & & & & & & & \\
\hline
\end{tabular}


APPENDIX G

PART 3: HABITAT MATRIX FOR BREEDING BIRDS OF ALBERTA (information adapted from Semenchuk, 1992)

\begin{tabular}{|c|c|c|c|c|c|c|c|c|c|c|c|c|c|c|c|}
\hline \multirow{3}{*}{$\begin{array}{l}\text { *In this column indicates } \\
\text { area-or disturbance- } \\
\text { sensitive species }\end{array}$} & \multicolumn{7}{|c|}{ Lowland Habitat } & \multicolumn{7}{|c|}{ Upland Habitat } & \multirow{3}{*}{ Special Needs } \\
\hline & \multicolumn{4}{|c|}{ Marsh } & \multicolumn{2}{|c|}{ Swamp } & & \multicolumn{2}{|c|}{ Open } & \multicolumn{5}{|c|}{ Woodland } & \\
\hline & \begin{tabular}{|l}
$\overline{\bar{\pi}}$ \\
营 \\
\end{tabular} & 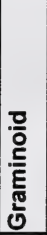 & 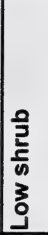 & : & 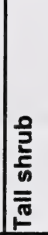 & 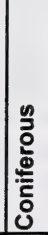 & 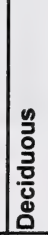 & 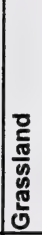 & 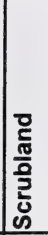 & 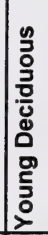 & $\begin{array}{l}\mathbf{0} \\
\mathbf{\Xi} \\
\mathbf{x} \\
\mathbf{\Sigma}\end{array}$ & 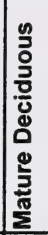 & 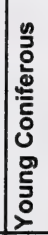 & 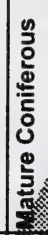 & \\
\hline \multicolumn{16}{|l|}{ Rusty Blackbird* } \\
\hline \multicolumn{16}{|l|}{ Brewer's Blackbird* } \\
\hline Common Grackle & & & & * & $\cdot$ & * & & & * & 盿 & 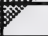 & & ${ }^{\star}$ & - & \\
\hline Brown-headed Cowbird & * & & & & * & & & * & * & (1) & * & & * & y & 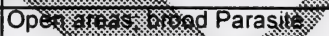 \\
\hline \multicolumn{16}{|l|}{ Northern Oriole } \\
\hline Rosy Finch* & & & * & & & & & * & & & $\bar{x}$ & 7 & & & Outcrops in \\
\hline \multicolumn{16}{|l|}{ Pine Grosbeak* } \\
\hline \multicolumn{16}{|l|}{ Purple Finch } \\
\hline Cassin's Finch & & & & & & & & & & \% & $x$ & & & * & Open montane forests \\
\hline \multicolumn{16}{|l|}{ House Finch } \\
\hline \multicolumn{16}{|l|}{ Red Crossbill ${ }^{*}$} \\
\hline White-winged Crossbill ${ }^{*}$ & & & & & & & & & $x$ & . & * & & (1) & 筮 & 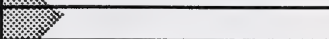 \\
\hline \multicolumn{16}{|l|}{ Common Redpoll ${ }^{*}$} \\
\hline \multicolumn{16}{|l|}{ Pine Siskin } \\
\hline American Goldfinch & & & * & & * & 2. & & & 䇾 & 型 & & 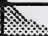 & (4) & 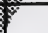 & \\
\hline Evening Grosbeak* & & & & & & w & & & \% & T. & s. & $x$ & ? & * & \\
\hline House Sparrow & & & & & 釆 & & & $3 \times$ & & & & & & & Human habitation \\
\hline
\end{tabular}




\section{APPENDIX G}

PART 4: HABITAT MATRIX FOR MAMMALS OF ALBERTA (adapted from Smith 1993)

\begin{tabular}{|c|c|c|c|c|c|c|c|c|c|c|c|c|c|c|c|}
\hline \multirow{3}{*}{$\begin{array}{l}\text { "In this column indicates } \\
\text { area-or disturbance-sensitive } \\
\text { species }\end{array}$} & \multicolumn{7}{|c|}{ Lowland Habitat } & \multicolumn{7}{|c|}{ Upland Habitat } & \multirow[t]{3}{*}{ Special Needs } \\
\hline & \multicolumn{4}{|c|}{ Marsh } & \multicolumn{2}{|c|}{ Swamp } & \multirow[b]{2}{*}{ 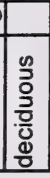 } & \multicolumn{2}{|c|}{ Open } & \multicolumn{5}{|c|}{ woodland } & \\
\hline & 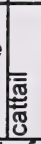 & 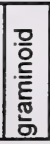 & \begin{tabular}{|l}
0 \\
3 \\
\\
$\frac{1}{5}$ \\
3 \\
3 \\
0
\end{tabular} & 8 & $\begin{array}{l}\frac{0}{3} \\
\frac{2}{5} \\
\overline{\frac{1}{0}} \\
\end{array}$ & 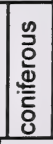 & & 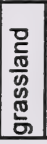 & 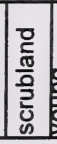 & 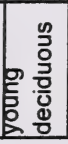 & 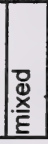 & 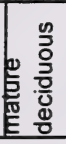 & ك. & 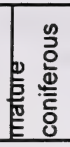 & \\
\hline \multicolumn{16}{|c|}{ Changes expected as a result of wastewater inflow } \\
\hline Habitat before inflows & $T^{*}$ & * & * & * & \# & * & * & " & $a^{*}$ & * & " & & & & \\
\hline \multicolumn{16}{|l|}{ Habitat after inflows } \\
\hline & & & & & & & & & & & 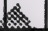 & & & & \\
\hline \multicolumn{16}{|l|}{ Species } \\
\hline Masked Shrew & & & & & ${ }^{*}$ & 7 & $\bar{x}$ & & & & 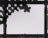 & & & & \% \\
\hline \multicolumn{16}{|l|}{ Prairie Shrew* } \\
\hline Dusky Shrew* & & * & " & $\pi$ & $\pi$ & 7 & " & & 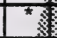 & 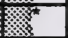 & * & & 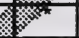 & & W K \\
\hline Wandering Shrew* & & & & & & & & & & x & & & & t & Morraxy \\
\hline Water Shrew* & & & & & & & & & & 楚 & 玟 & & * & * & Creeks, ponds and lakes \\
\hline Arctic Shrew* & & & & * & $\%$ & * & $\pi$ & & & 筟 & $x$ & s. & $x^{*}$ & 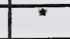 & \\
\hline \multicolumn{16}{|l|}{ Pygmy Shrew* } \\
\hline Little Brown Bat & & & & & & * & 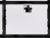 & & 烟 & & * & & 埾 & 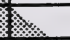 & Caves for hiberacula \\
\hline Northern Long-eared Bat" & & & & & & & & & $x$ & & * & 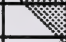 & $x$ & x. & Caves for hibernacula \\
\hline Long-eared Bat* & & & & & & & & 曻 & 森 & & & & x. & & Sheltering rock outcrops \\
\hline Long-legged Bat* & & & & & & & & & 济 & 管 & 柆 & & & * & $\begin{array}{l}\text { Rocky outcrops and } \\
\text { caves }\end{array}$ \\
\hline Western Small-footed Bat* & & & & & & & & 率 & & & & & & & $\begin{array}{l}\text { Rock outcrops and } \\
\text { crevices in badlands }\end{array}$ \\
\hline \multicolumn{16}{|l|}{ Silver-haired Bat" } \\
\hline Big Brown Bat & & & & 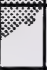 & * & 在 & 奖 & * & $*$ & 曻 & * & * & & & $\begin{array}{l}\text { Caves and crevices, } \\
\text { buildings }\end{array}$ \\
\hline Red Bat & & & 梦 & & & & 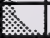 & & 紋 & * & t & & ॠ & & \\
\hline \multicolumn{16}{|l|}{ Hoary Bat* } \\
\hline $\mathrm{Pika}^{*}$ 湆 & & & & & & & & 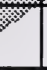 & & & & & & & $\begin{array}{l}\text { Rock sides and talus } \\
\text { slopes }\end{array}$ \\
\hline Nuttal's Cottortan. & & & & 怒 & & & & * & $*$ & & & & & & $\begin{array}{l}\text { RIver bottomiand and } \\
\text { rocky valleys }\end{array}$ \\
\hline Snowshoe Hares , , , & & 管 & & & 然 & & & & * & \% & * & * & * & * & \\
\hline White-tailed Jack & & & 椊 & & & & & * & & & & & & & Open areas \\
\hline \multicolumn{16}{|l|}{ Least Chiprifin } \\
\hline Yellowking Chipmunk* & & . & & & & & & & & & & & & * & $\begin{array}{l}\text { Mountains: forest } \\
\text { openings and clearings }\end{array}$ \\
\hline Red-tailed Chipmunk* & \% & & & & & & & & & & * & & & * & $\begin{array}{l}\text { Between } 1500 \text { and } 2100 \\
\text { metres }\end{array}$ \\
\hline Woodchuck & & & & & & & & * & * & * & * & & & & \\
\hline Yellow-bellied Marmot" & & & & & & & & & & & & & & & Rocky outcrops \\
\hline Foary Marmot" & & & & & & & & * & & & & & & & Mountains \\
\hline 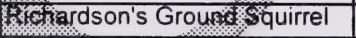 & & & & & & & & * & & & & & & & Gravelly or sandy soils \\
\hline Wotumbian Erostid Squirrel* & & & & & & & & * & & & & & & & $\begin{array}{l}\text { Mountain meadows and } \\
\text { bottomlands }\end{array}$ \\
\hline 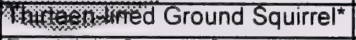 & & & & & & & & & ${ }^{\star}$ & * & & & & & \\
\hline Franklin's Ground Squirrel* & & & & & & & & & * & * & & & & & \\
\hline
\end{tabular}


APPENDIX G

PART 4: HABITAT MATRIX FOR MAMMALS OF ALBERTA (adapted from Smith 1993)

\begin{tabular}{|c|c|c|c|c|c|c|c|c|c|c|c|c|c|c|c|}
\hline \multirow{3}{*}{$\begin{array}{l}\text { "In this column indicates } \\
\text { area-or disturbance-sensitive } \\
\text { species }\end{array}$} & \multicolumn{7}{|c|}{ Lowland Habitat } & \multicolumn{7}{|c|}{ Upland Habitat } & \multirow[t]{3}{*}{ Special Needs } \\
\hline & & \multicolumn{3}{|c|}{ Marsh } & \multicolumn{2}{|c|}{ Swamp } & \multirow[b]{2}{*}{ 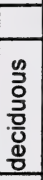 } & \multicolumn{2}{|c|}{ Open } & \multicolumn{5}{|c|}{ woodland } & \\
\hline & & 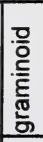 & $\begin{array}{l}\text { 울 } \\
\text { 논 } \\
\text { ș } \\
\text { 으 } \\
\end{array}$ & 8 & 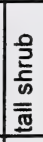 & 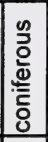 & & $\begin{array}{l}\frac{0}{\frac{0}{0}} \\
\frac{0}{0} \\
\frac{3}{0} \\
\frac{0}{0} \\
\end{array}$ & 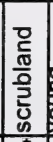 & 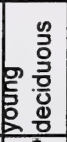 & & 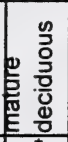 & 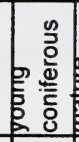 & 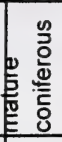 & \\
\hline Golden-mantled Ground Squirre & & & & & & & & & & & & & & & Mountaik \\
\hline Gray Squirrel & & & & & & & & & & & * & & & & . \\
\hline Red Squirrel & & & & & & & & & & & + & & & & \\
\hline Northern Flying Squirre $^{*}$ & & & & & & & & & & & . & & & & est Cavities \\
\hline Northern Pocket Gopher ${ }^{*}$ & & & & & & & & & & & & & & & \\
\hline Olive-backed Pocket Mouse* & & & & & & & & $\star$ & & & & & & & soil \\
\hline Ord's Kangaroo Rat" & & & & & & & & * & & & & & & & He sparse \\
\hline Beaver & " & * & * & * & * & ${ }^{\star}$ & * & & & 玟 & & & & & De\& \\
\hline Western Harvest Mouse & & & & & & & & * & 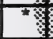 & & x & & & & . \\
\hline Deer Mouse & & & & & * & * & " & " & * & & 梦 & & * & - & \\
\hline Northern Grasshopper Mouse ${ }^{\star}$ & & & & & & & & * & & & & & & & Sagebrush \\
\hline Bushy-tailed Woodrat* & & & & & & & & & 然 & & & & & & $\begin{array}{l}\text { Rock slides, caves and } \\
\text { crevices }\end{array}$ \\
\hline Southern Red-backed Vole* & & & & & * & $\star$ & * & & 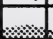 & & * & 策 & 烈 & & \\
\hline Heather Vole & & & * & 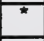 & $\bar{k}$ & $*$ & & & 列 & 梦 & 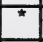 & & $x$ & m & \\
\hline Meadow Vole & & * & & & & & & 筮稀 & 柆 & & 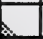 & & m & 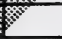 & \\
\hline Long-tailed Vole* & & * & & & & s. & 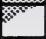 & & $x$ & & 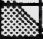 & & ( & & Mountains \\
\hline Taiga Vole* & & & & & . & 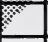 & & 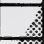 & is & & & & 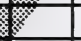 & & Horsetails \\
\hline Prairie Vole* & & & & & & & & 卒 & & & & & & & $\begin{array}{l}\text { Habitat enclosed by } \\
\text { aspen }\end{array}$ \\
\hline Water Vole* & & & & 㱍 & & & 糸 & & & & & & & & $\begin{array}{l}\text { Alpine meadows near } \\
\text { streams }\end{array}$ \\
\hline Sagebrush Vole* & & 8 & 烈 & & & 吵 & 禁 & * & 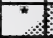 & 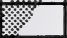 & & & & & Sagebrush \\
\hline Muskrat & s" & 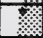 & 管 & & & & 筮 & & $x$ & & & & & & Permanent water \\
\hline Brown Lemsinging* & & 筮 & $*$ & & & & & $x$ & 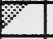 & & & & & & Mountains \\
\hline 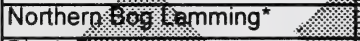 & & s.s. & $\delta^{*}$ & * & & & & 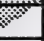 & & & & & & & \\
\hline 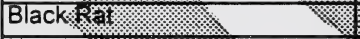 & & 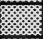 & 标 & & & & & & & & & & & & Human habitation \\
\hline Norway $+x$ & 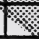 & 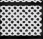 & & a & & & & & & & & & & & Human habitation \\
\hline House Mou's & & 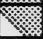 & & & a & & & & $x^{*}$ & & & & & & Human habitation \\
\hline 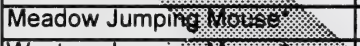 & & 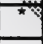 & & & 悲 & & & & & & & & & & \\
\hline Western Jumpirig / & & & 梦 & & 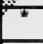 & & & & & & & & & & \\
\hline Porcupine & & & & & & & & & & & * & & & & \\
\hline Coyote & & & & & & " & * & * & * & & " & & * & & \\
\hline Gray ${ }^{3}$ Nolf* & & 然 & & & & 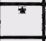 & $\hbar$ & & * & & & * & & * & \\
\hline Afsic Fox & & & & & & & & & & & & & " & * & Open areas \\
\hline Red Fox & & & & & ${ }^{*}$ & 7 & * & $*$ & 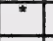 & 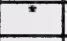 & 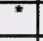 & " & * & 7 & \\
\hline Suift Fox & & & & & & & & * & & & & & & & \\
\hline Gray Fox & & & & & & & & & & * & & 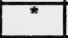 & & & \\
\hline brack Bear ${ }^{*}$ & & & & & & & & & & & * & & * & * & \\
\hline 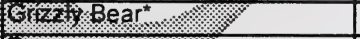 & & & & & & & & * & * & & & & & & \\
\hline Regcoor . & & & & & & & * & * & " & " & * & * & & & \\
\hline Markr & & & & & & & & & & & & & & 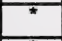 & \\
\hline Fisher $^{2}$ & & & & & & & & & & & & & & * & \\
\hline
\end{tabular}




\section{APPENDIX G}

PART 4: HABITAT MATRIX FOR MAMMALS OF ALBERTA (adapted from Smith 1993)

\begin{tabular}{|c|c|c|c|c|c|c|c|c|c|c|c|c|c|c|c|}
\hline \multirow[b]{3}{*}{$\begin{array}{l}\text { In this column indicates } \\
\text { area-or disturbance-sensitive } \\
\text { species }\end{array}$} & \multicolumn{7}{|c|}{ Lowland Habitat } & \multicolumn{7}{|c|}{ Upland Habitat } & \multirow[t]{3}{*}{ Special Needs } \\
\hline & \multicolumn{4}{|c|}{ Marsh } & \multicolumn{2}{|c|}{ Swamp } & \multirow[b]{2}{*}{ 올 } & \multicolumn{2}{|c|}{ Open } & \multicolumn{5}{|c|}{ woodland } & \\
\hline & $\frac{\bar{\pi}}{\mathbb{E}}$ & 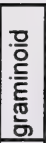 & $\begin{array}{l}\text { 을 } \\
\frac{1}{10} \\
3 \\
\text { 으 }\end{array}$ & ర్ర & $\frac{\frac{0}{2}}{\frac{2}{6}}$ & 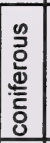 & & 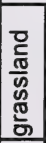 & 믈 & $\frac{\text { g }}{\mathrm{g}}$ & & 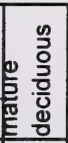 & 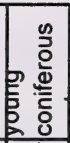 & 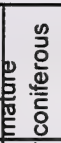 & \\
\hline \multicolumn{16}{|l|}{ Ermine } \\
\hline \multicolumn{16}{|l|}{ Least Weasel" } \\
\hline \multicolumn{16}{|l|}{ Long-tailed Weasel* } \\
\hline \multicolumn{16}{|l|}{ Black-footed Ferret ${ }^{\star}$} \\
\hline \multicolumn{16}{|l|}{ Mink ${ }^{\star}$} \\
\hline \multicolumn{16}{|l|}{ Wolverine* } \\
\hline \multicolumn{16}{|l|}{ Badger } \\
\hline \multicolumn{16}{|l|}{ Striped Skunk } \\
\hline River Otter* & & & & & $\bullet$ & * & * & & & & & & & & Rivers, mand ponds \\
\hline Cougar & & & & & & & & & & & & & & & Mountains and foothills \\
\hline \multicolumn{16}{|l|}{ Canada Lynx } \\
\hline \multicolumn{16}{|l|}{ Bobcat* } \\
\hline \multicolumn{16}{|l|}{ Wapiti* } \\
\hline \multicolumn{16}{|l|}{ Mule Deer ${ }^{*}$} \\
\hline \multicolumn{16}{|l|}{ White-tailed Deer } \\
\hline Moose* & & & & & & & & & & & & & & & Lakes, bogs and streams \\
\hline \multicolumn{16}{|l|}{ Caribou $^{*}$} \\
\hline \multicolumn{16}{|l|}{ Pronghorn ${ }^{\star}$} \\
\hline \multicolumn{16}{|l|}{ Bison* } \\
\hline Mountain Goat* & & & 2 & & & & 临 & & & 然 & & & & & Rocky terrain \\
\hline Bighorn Sheep* & & & & 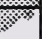 & & & 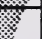 & & & & & & & & Rocky terrain \\
\hline
\end{tabular}




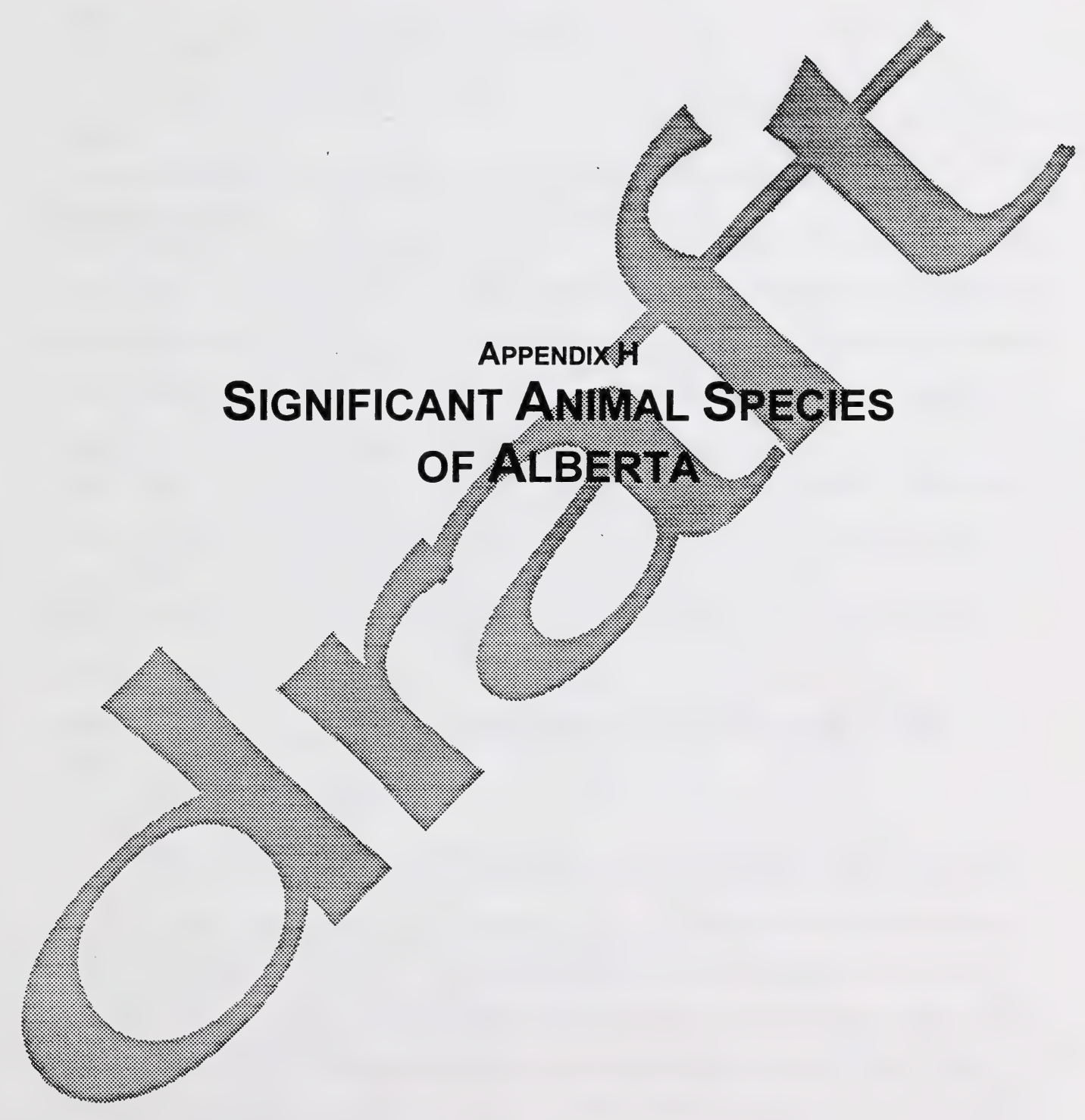





\section{H. Significant Animal Species of Alberta}

PART 1

SIGNIFICANT HERPTILE (REPTILE AND AMPHIBIAN) SPECIES OF ALBERTA

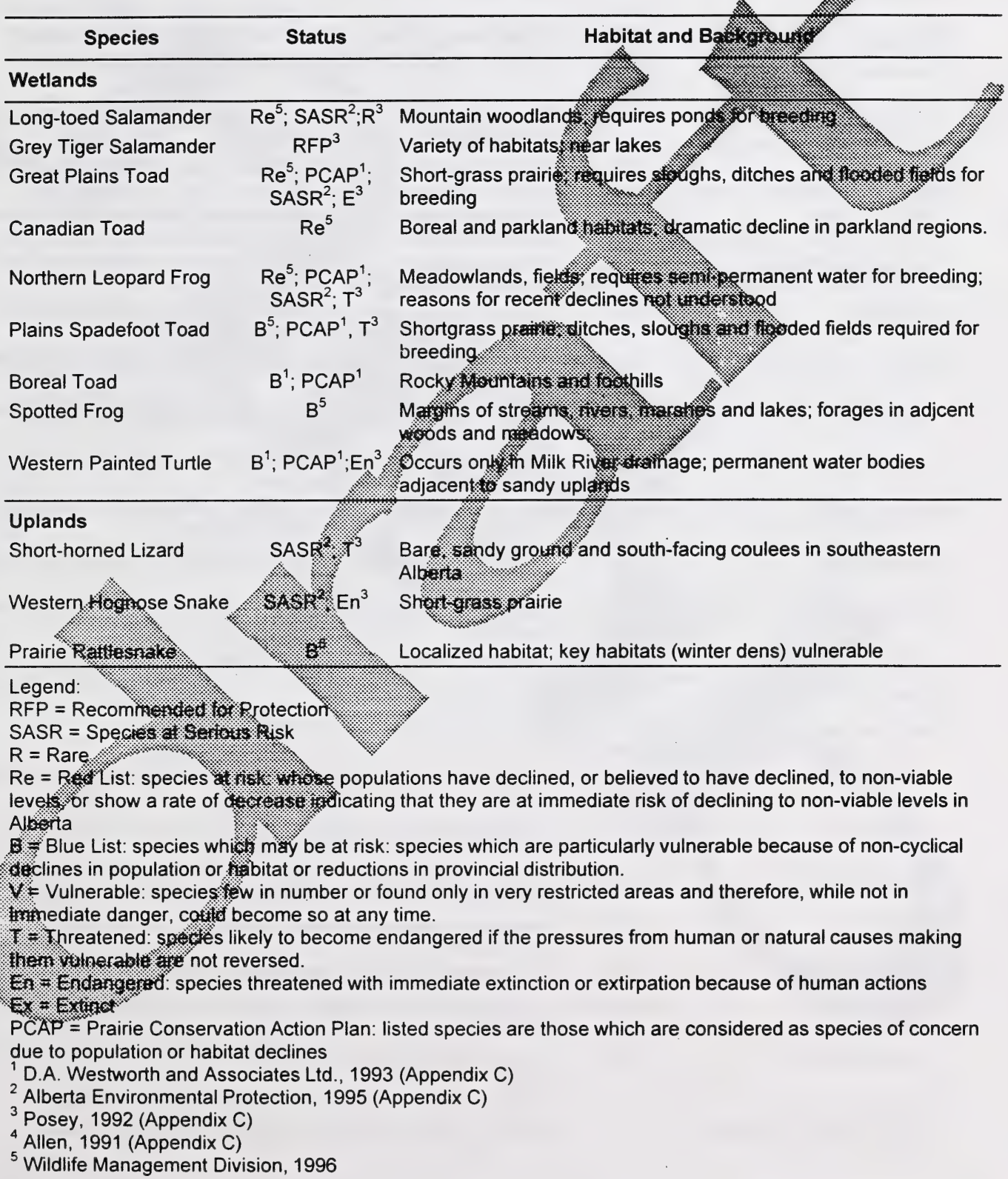


PART 2

Significant BREEDING BiRd SPECIES OF Alberta

\begin{tabular}{|c|c|c|}
\hline Species & Status & Breeding Habitat and background \\
\hline \multicolumn{3}{|l|}{ Wetlands } \\
\hline Whooping crane & $\begin{array}{l}\mathrm{En}^{1,2,3} ; \mathrm{Re}^{5} \\
\mathrm{SASR}^{2}\end{array}$ & $\begin{array}{l}\text { Vast open marshes: declines due to hunting, egg-collecting, habitat } \\
\text { destruction }\end{array}$ \\
\hline Piping Plover & $\begin{array}{l}E n^{1,2,3} ; \operatorname{Re}^{5} \\
\operatorname{SASR}^{2}\end{array}$ & Sandy shores: recreational use of beaches threatens brexitg habitat. \\
\hline Eskimo Curlew & $E n^{1}, B^{1}$ & Tundra; possibly extinct: unlikely to be aff \\
\hline Long-billed Curlew & $\begin{array}{l}B^{5}, T^{1}, R^{1} \\
\text { SASR }^{2}\end{array}$ & Prairie : declines due to ov unting an sland habitat \\
\hline Cooper's Hawk & $V^{1}$, PCAP $^{1}$ & 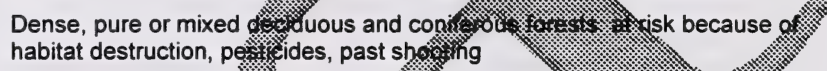 \\
\hline Short-eared Owl & $B^{5}$ & Grassland habitat: caju of populition declines unk \\
\hline Great Gray Owl & $V^{1}, P^{\prime} A P^{1}$ & 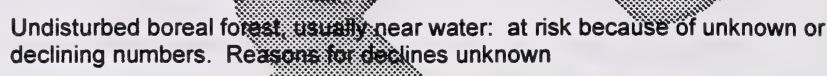 \\
\hline American White Pelican & $\mathrm{B}^{1,3}, \mathrm{PCAP}^{1}$ & $\begin{array}{l}\text { Colonial breeder on tre. } \\
\text { activity. }\end{array}$ \\
\hline Bald Eagle & $\mathbf{B}^{1}, \mathrm{PCAP}^{1}$ & $\begin{array}{l}\text { Tall trees near a large body of wated } \\
\text { declines due to. }\end{array}$ \\
\hline Osprey & $\mathbf{B}^{1}$ & 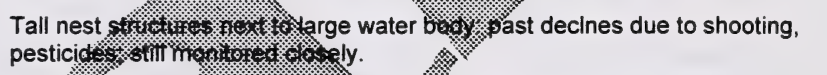 \\
\hline Caspian Tern & $B^{1}$ & 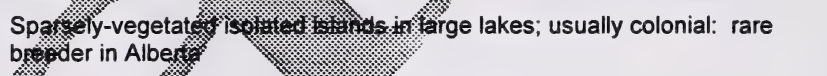 \\
\hline Trumpeter Swan & $\begin{array}{l}\mathrm{B}^{5}, \mathrm{En}^{1,2,3} \\
\mathrm{PCAP}^{1} ; \mathrm{SAS}^{2}, 2\end{array}$ & 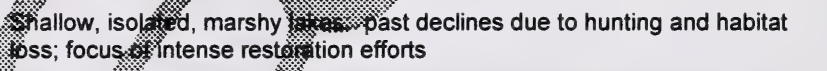 \\
\hline American Avocet & & 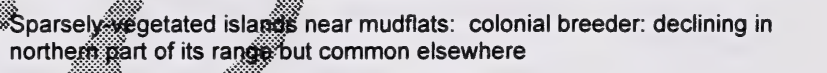 \\
\hline Marbled Godwit & & 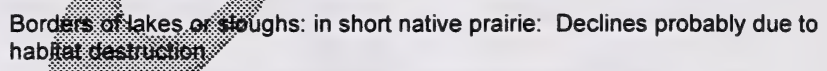 \\
\hline White-face & & 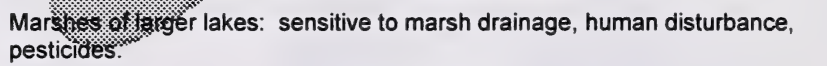 \\
\hline Willet & 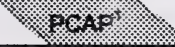 & Common in grassland and parkland regions \\
\hline \multicolumn{3}{|l|}{ Uplands } \\
\hline Peregrine Falcon & $\mathrm{Re}^{5}, \mathrm{En}$ & Wiffs: unlikely to be affected by treatment wetland \\
\hline Baird's \%arrow & 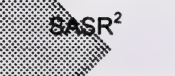 & $\begin{array}{l}\text { Tall, open grassland: declines due to habitat destruction; intolerant of heavy } \\
\text { grazing }\end{array}$ \\
\hline Buknowing Owl & $\mathrm{En}^{2,3}$ & $\begin{array}{l}\text { Level, open shortgrass areas with colonial rodents and nest burrows: } \\
\text { declines due to habitat and prey species destruction }\end{array}$ \\
\hline feruginous Hawk & $\mathrm{B}^{5}, \mathrm{En}^{2} ; \mathrm{SASR}^{2}$ & $\begin{array}{l}\text { On cliffs or tall structures in sparsely treed dry mixed prairie: declines due to } \\
\text { encroachment of aspen, spread of agriculture; population recovering }\end{array}$ \\
\hline Sage Grouse & $B^{5}$ & $\begin{array}{l}\text { Restricted to sagebrush-grassland habitat, currently being degraded; } \\
\text { population declining rapidly }\end{array}$ \\
\hline 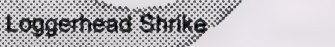 & $\mathrm{SASR}^{2}$ & Lightly wooded river valleys and coulees: reason for decline not understood \\
\hline 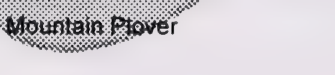 & $\mathrm{En}^{2} ; \mathrm{SASR}^{2}$ & $\begin{array}{l}\text { Large areas of short grasslands: declines due to large-scale habitat } \\
\text { destruction }\end{array}$ \\
\hline Upland Sandpiper & $\mathrm{SASR}^{2}$ & $\begin{array}{l}\text { Wide expanses of open, grassy uplands: declines due to loss of grassland } \\
\text { habitat; trends unclear }\end{array}$ \\
\hline Bay-breasted Warbler & $B^{5}$ & Declining, dependent on old-growth forest; intolerant of harvest \\
\hline Black-throated Green Warbler & $B^{5}$ & Dependent on old-growth coniferous forest: intolerant of harvest \\
\hline
\end{tabular}




\section{PART 2}

SignificANT BREEDING BiRd SPECIES OF ALBERTA

\begin{tabular}{lcl}
\multicolumn{1}{c}{ Species } & Status & \multicolumn{1}{c}{ Breeding Habitat and background } \\
\hline Sprague's Pipit & $\mathrm{B}^{5}$ & Depends on grasslands; dramatic population declines \\
Cape May Warbler & $\mathrm{B}^{5}$ & Depends on old-growth forest \\
\hline
\end{tabular}

Legend:

$\mathrm{R}=$ Rare

SASR $=$ Species at Serious Risk

$\mathrm{Re}=\mathrm{Red}$ List: species at risk: whose populations have declined, or believed to ha to non-viable levels, or show a rate of decrease indicating that they are at immediatisisk of de Alberta

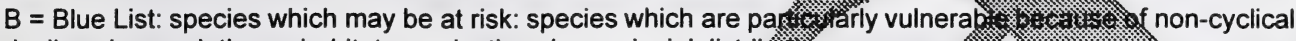
declines in population or habitat or reductions in provincial distribistion.

$\mathrm{V}=$ Vulnerable: species few in number or found only in very res.t. immediate danger, could become so at any time.

$T=$ Threatened: species likely to become endangered if the pres.s. them vulnerable are not reversed

En = Endangered: species threatened with immediate extinction of

Ex $=$ Extinct

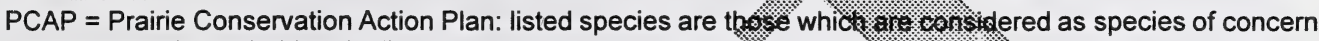
due to population or habitat declines

${ }^{1}$ D.A. Westworth and Associates Ltd., 1993 (Appendix C)

2 Alberta Environmental Protection, 1995 (Appendix C)

${ }^{3}$ Posey, 1992 (Appendix C)

${ }^{4}$ Allen, 1991 (Appendix C)

${ }^{5}$ Wildlife Management Division, 1996 (Appendix
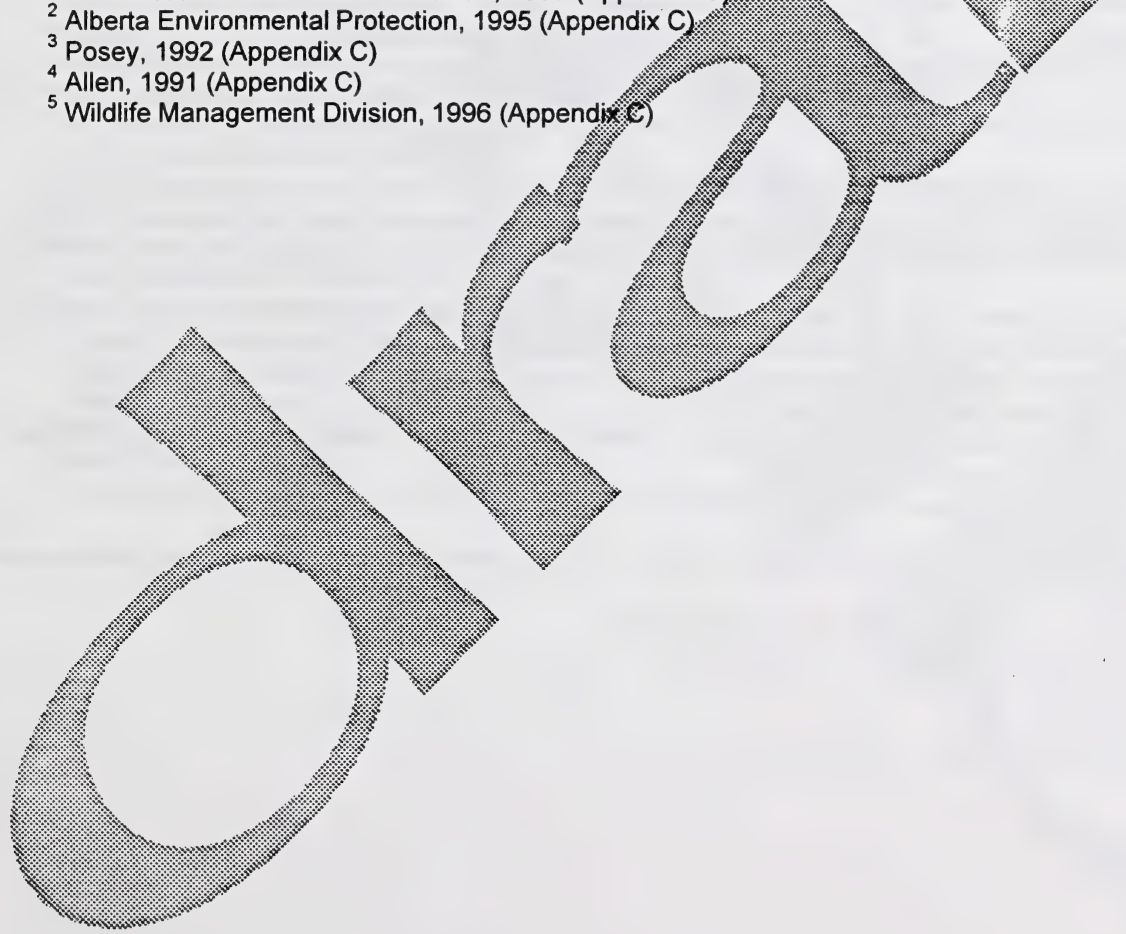


\section{PART 3}

\section{Significant Mammal SPECIES OF Alberta}

\begin{tabular}{|c|c|c|}
\hline Species & Status & Habitat and Background \\
\hline \multicolumn{3}{|l|}{ Wetlands } \\
\hline Yellow-cheeked Vole & $\operatorname{Re}^{1} ; \mathrm{SASR}^{2}$ & $\begin{array}{l}\text { Upland areas along rivers near stands of horsetails: found only along the } \\
\text { Athabasca River; possibly extirpated. }\end{array}$ \\
\hline Wandering Shrew & $B^{1}$ & Collected only at one site along a mountain stream in a conis \\
\hline River Otter & $B^{1}$ & $\begin{array}{l}\text { Large tracts of wooded or brushy habitat: sens to hus disturbance and } \\
\text { habitat fragmentation }\end{array}$ \\
\hline Brown Lemming & $B^{1}$ & $\begin{array}{l}\text { Shrub-sedge meadow in subal forest in portion of Rocky } \\
\text { Mountains: limited in distrib }\end{array}$ \\
\hline \multicolumn{3}{|l|}{ Uplands } \\
\hline Swift Fox & $\begin{array}{l}\mathrm{Re}^{5}, \mathrm{En}^{1,2,3} \\
\mathrm{SASR}^{2}\end{array}$ & 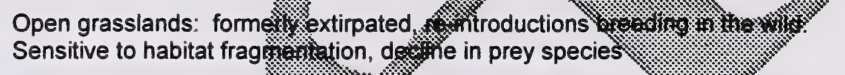 \\
\hline Wood Bison & $\begin{array}{l}\mathrm{Re}^{5}, \mathrm{En}^{1,2,3} \\
\mathrm{SASR}^{2}\end{array}$ & $\begin{array}{l}\text { Sensitive to hunting, habij } \\
\text { population in captivity; dises }\end{array}$ \\
\hline Woodland Caribou & $B^{5}$ & 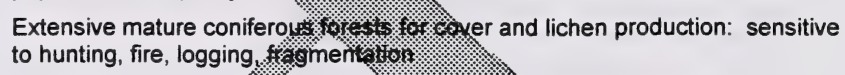 \\
\hline Grizzly Bear & $B^{5}$ & Threatened by loss of widerness hating, \\
\hline Ord's Kangaroo Rat & $B^{5}$ & 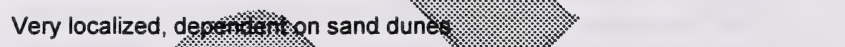 \\
\hline Red-tailed Chipmunk & $\mathrm{B}^{5}$ & Population low \\
\hline Wolverine & $B^{5}$ & 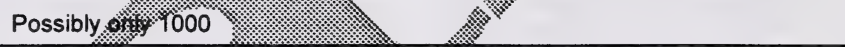 \\
\hline \multicolumn{3}{|c|}{ 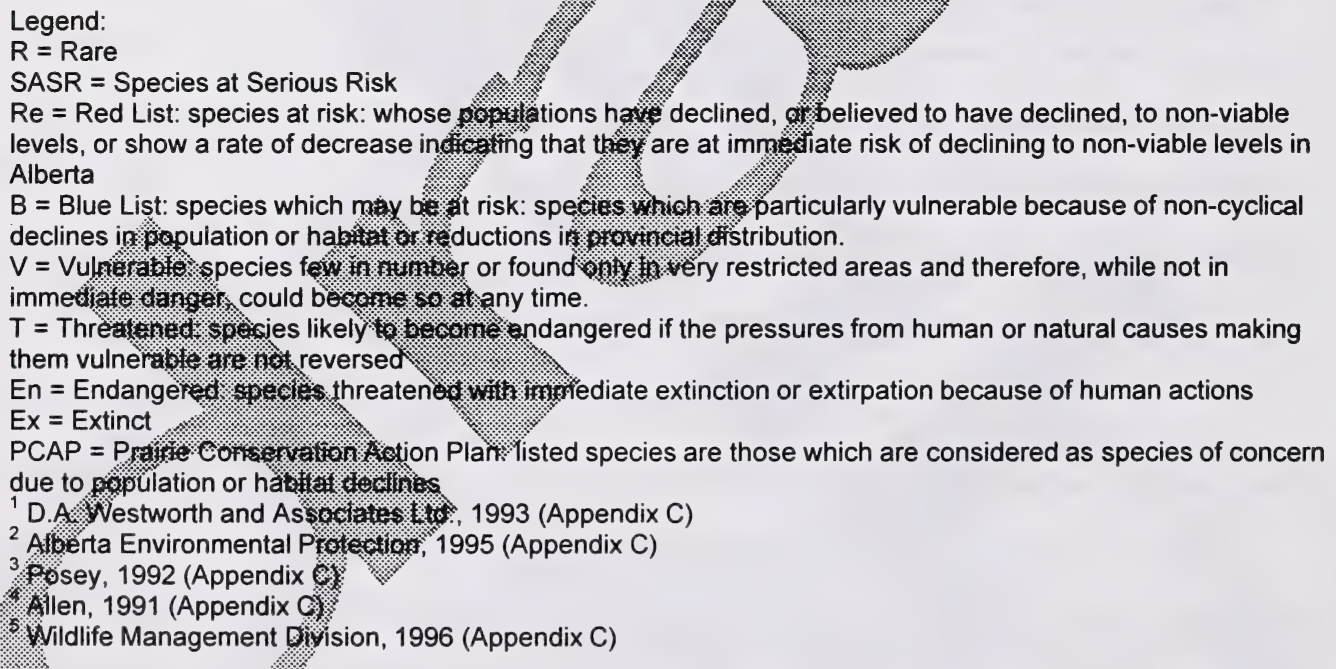 } \\
\hline
\end{tabular}




\section{PART 4}

SIGNIFICANT FISH SPECIES OF ALBERTA

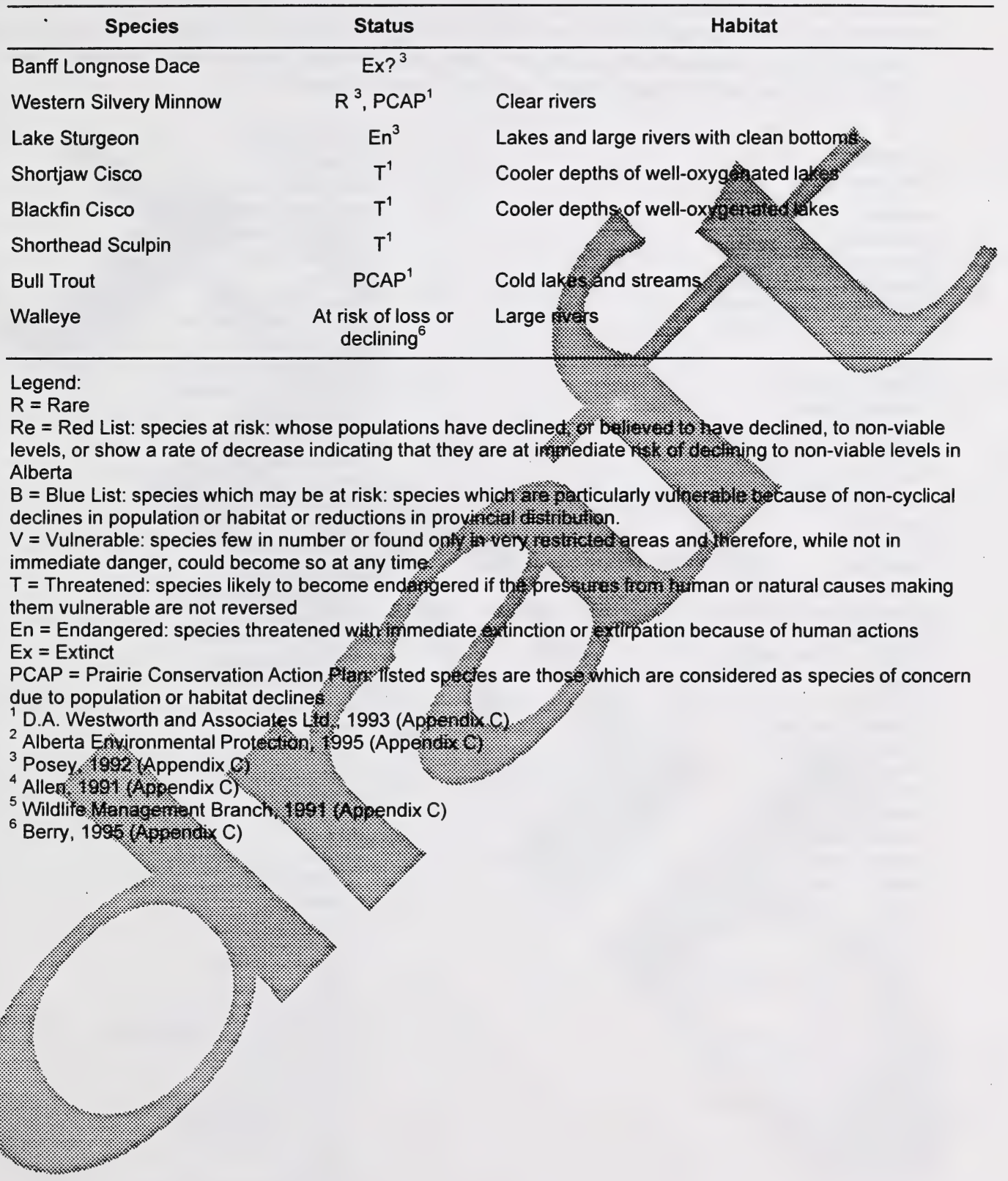




\section{Part 5}

Sensitive species not currently believed to be at risk; but which may require special management to address concerns related to low natural populations, limited provincial distribution or demographic/life history features that make them vulnerable to human related changes to the environment particular biological needs (designated "Yellow" status by Wildlife Management Division, 1996, includes Yellow A and B).

\section{Amphibians}

Long-toed Salamander

\section{Reptiles}

Bull Snake

Plains Garter Snake

Red-sided Garter Snake

Wandering Garter Snake

Western Painted Turtle

\section{Birds}

American Arocet

American Bittern

American Dipper

American White Pelican

Baird's Sparrow

Bald Eagle

Barred Owl

Black Swift

Black Tern

Black-crowned Night-heron

Black-backed woodpecker

Black-necked Stilt

Black-and-white Warbler

Bobolink

Boreal Owl

Brewer's Sparrow

Broad-winged Hawk

Brown Creeper

Brown thasher.

Canada Mationer:

Caspian Terr.

Chestnut-sided Wat ot ter.

Clarke's Crebe

Clarke's Nutsetatioker

Clay-coloured Sparrov*

Coopeis: Hawk

Doubte-crested Cormoran

Forster's Tern

soofden Eagle

Gifden-crowned Sparrow:

G. asshopper Sparrow

Great Blue Heron

crsaticrested Flycatcher

Great sray OWI

Vhatlequm Duck

Horned:stebe

Herring Gull

Lark Sparrow

Lesser Yellowlegs

Loggerhead Shrike

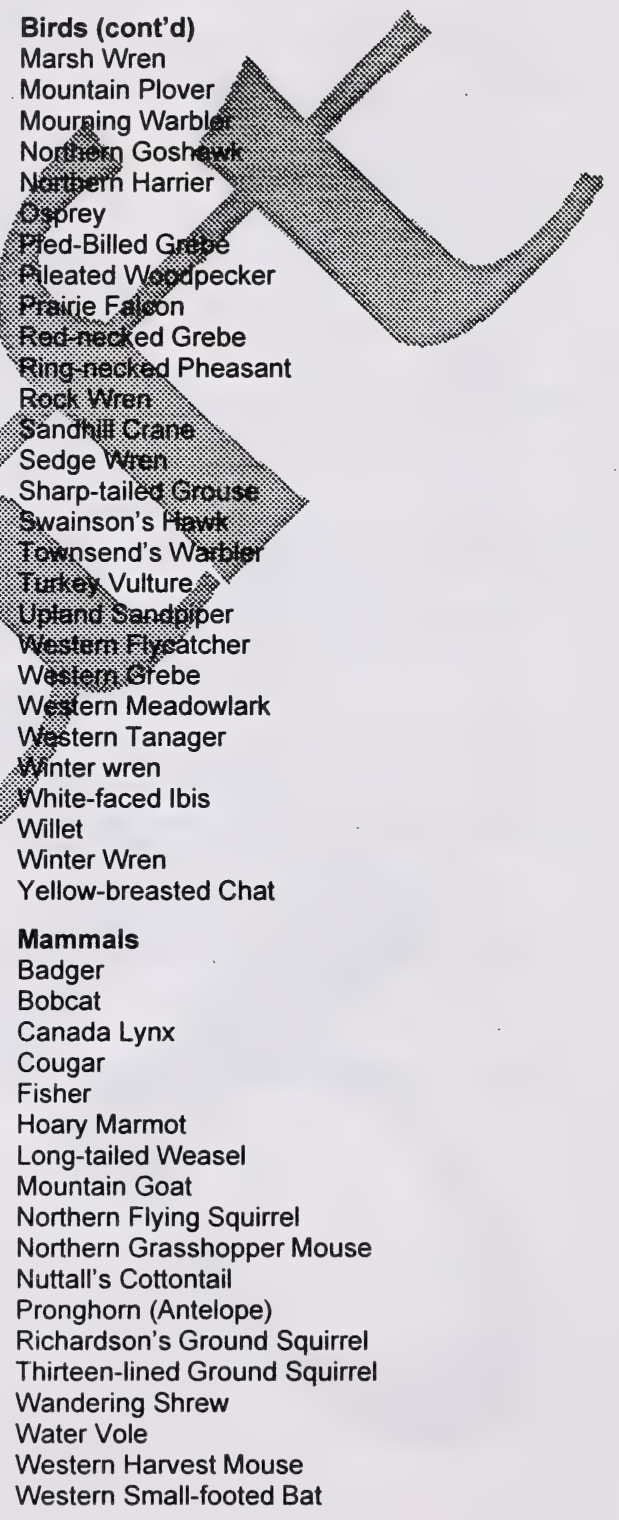




\section{APPENDIX \\ ANNOTATED BIBLIOGRARHYFOR WETLANDEVALUATIONS}


$\nabla$

.

,

,

,

,

,

,

,

,

,

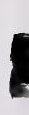

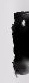

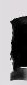

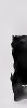

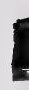

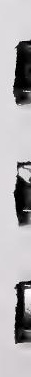




\section{Annotated Bibliography for Wetland Evaluation}

\section{A. General}

Alberta Environmental Protection. 1995. Alberta's state of the virong a comprehensive report. Publication I/583, Alberta Environmental Protectiog:

Alberta Environmental Protection. 1993.

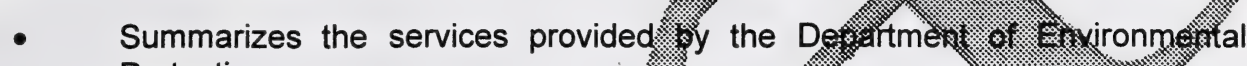
Protection.

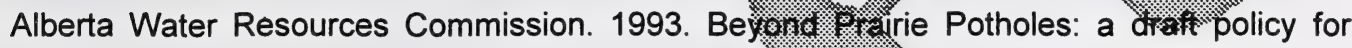
managing Alberta's peatlands and non-settled area whtlands: for discussion purposes. Alberta Water Resources Commission, Edmonton.

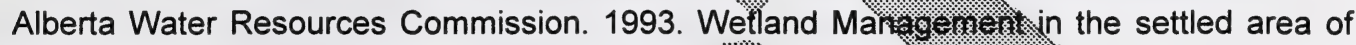
Alberta: an interim policy. Alberta Water Resolt:

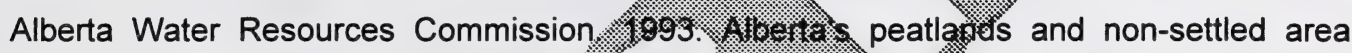

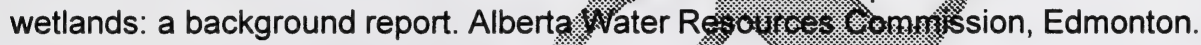

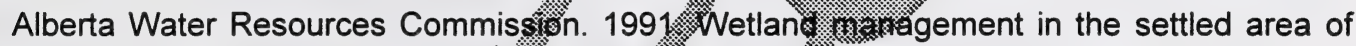
Alberta: a summary of public cominents. Alb

Alberta Water Resources Cofmission. 490 . Wetlais management in the settled area of Alberta: a background for Edmonton.

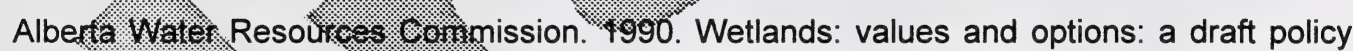

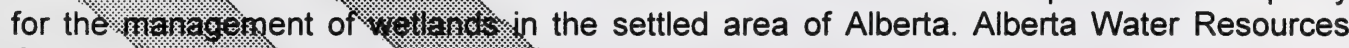
Commission. : arimonton.

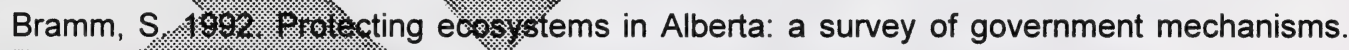

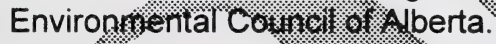

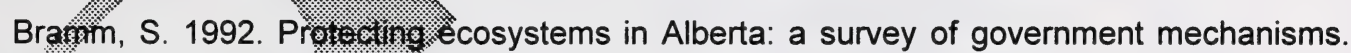
Exyironmental Cound of ixiberta, Edmonton, Alberta.

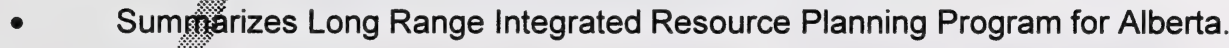

Cupland, R.T. 987 . Endangered prairie habitats: the mixed prairie. In Holroyd, G.L., P. W. Stepney G.C. Trottier, W.B. McGillivray, D.M. Ealey and K. E. Eberhart. 1987. Endangered. species in the prairie provinces. Provincial Museum of Alberta Natural History O.c.e.s.

Indicates the decline of woodland on prairie in Alberta and Saskatchewan.

D.A. Westworth and Associates Ltd. 1993. Functions and values of Alberta's wetlands. Report for Wetlands Management Steering Committee. North Petroleum Plaza, Edmonton, Alberta. 
- Summarizes function and values of wetlands, including social, economic, hydrologic habitat, heritage and water quality improvement functions.

D.A. Westworth \& Associates Ltd. 1990. Significant natural features of the eastern boreal forest region of Alberta. Tech. Rept. for Alberta Forestry, Lands and Wildlife.

- details locations of regionally, provincially and nationally significant significant features; significance based on analysis of hydrology, landform, rare flora and fauna, fisheries, wildlife corridors, wintering areas for mooc habitat for furbearers, and waterfowl staging.

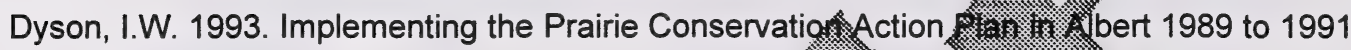
- two years of progress. In Holroyd et al. 1993 (above)

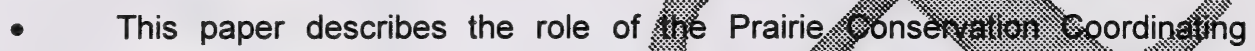

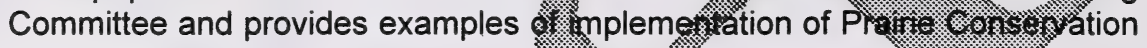
Action Plan goals.

Dyson, I.W. 1993. Public land management appksuleses for conserving native prairie environments - some Alberta examples. In Holroyd et:ati 60

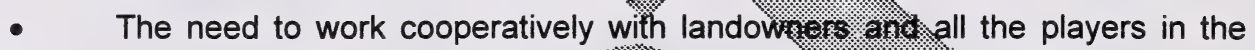
prairie landscape mosaic is impetis

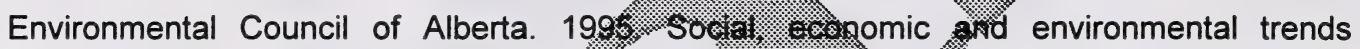

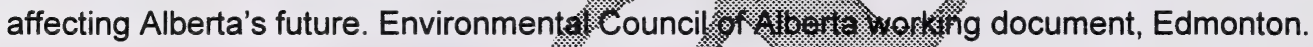

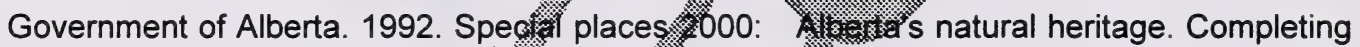

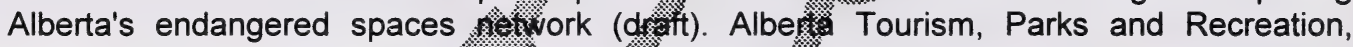
Forestry, Lands and Wildlife.

Holroyd, G., G. Burns and HW. Smith, 38. Endangered species and prairie conservation

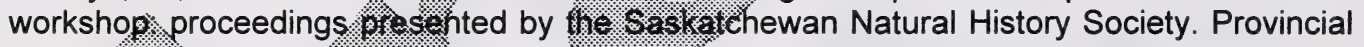

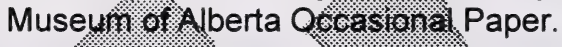

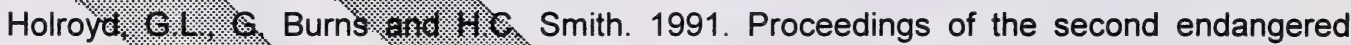

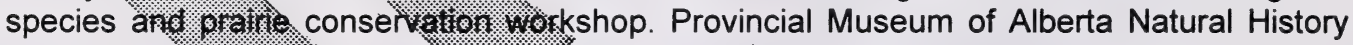

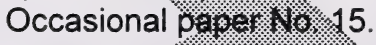

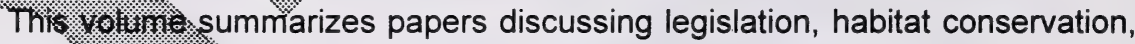
etc. in me grome provinces.

Hofroyd, G.L., H.L. Vickson, M.Regnier and H.C. Smith. 1993. Proceedings of the third orairie conservation/and endangered species workshop. Provincial Museum of Alberta occasional Paper No. 19.

Netfield, M., J. Wilk, K. Woolnough and B. Hoskin. 1985. Wildlife habitat requirement sumnmaries for selected wildlife species in Alberta. Alberta Energy and Natural Resources (F) Tedratical Report T/73), Fish and Wildlife Division, Edmonton.

Pachal, D. 1992. Wild Alberta. Environmental Council of Alberta, Edmonton, Alberta.

- Tabulates significant natural areas proposed for protection, and rationale for protection.

Pachal, D. 1992. Wild Alberta. Environmental Council of Alberta. 
- $\quad$ Lists and maps significant natural areas proposed for protection, provides rationale for them.

Posey, M. 1992. Saving the strands of life: Alberta's biodiversity. Environmental Council of Alberta, Edmonton.

Strong, W.L., B.K. Calverley, A.J. Richard, and G.R, Stewart. 1993. Characterization of wetlands in the settled areas of Alberta. Rept. for Wetlands Management Steering Committee, Edmonton, Alberta.

- Summarizes wetland characteristics of the 34 ecosisticts that occur within the Settled Area of Alberta; including various measit: $2=$. of Vulnerability; such as climatic vulnerability, arable land ratkg, numbar or watlands per $\mathrm{km} 2$ average wetland size, degree of water of rmanency humplos ol waterfowl por $\mathrm{km} 2$, percent developed land and number of drainge projects:

Usher, R. 1990. Alberta's wetlands: water in the baikl Environmental Council of Allatita.

Summarizes benefits and functions of wetrands:

Usher, R. and J. Scarth. 1990. Alberta's wetlands: water in tho tomk. Environmental Council of Alberta, Edmonton, Alberta.

Wildlife Management Branch. 1991. The statts or : 11:eeta Wildlife, Rept. for Alberta Forestry, Lands and Wildlife Fish and Wildlife Divisior.

- Assigns status to reptites, ampibiaps. 3iras. and mammals of Alberta. Summarizes habitat parameter and backigrarnd in species designated red, yellow and blue; the three highest categoites of significance.

Wildlife Management Branch 1991. The siaut of Alberta Wiildlife. Alberta Forestry, Lands and Wildife, Fish and Wildlife. Wildlife Managemen Branch, Edmonton.

Divides amphibians, reptiles. ondes, and mammals into four status categories according to the degree of itsk attached to their persistence.

\section{B. Plants and Plant Communities}

Achuff, P.L. 19897. Raro vascular plants in the Rocky Mountains of Alberta. In: Holroyd et al. 1987 (abovere).

Shows distribytion of rare plants within the three montane ecoregions of Alberta.

Alberta Energy, Forestry, Lands and Wildlife. 1992. Alberta plants and fungi: a master species list and spesies list group checklists. General Services Division, Editorial Services.

Aten L. 1991. S:atus of plant conservation in Alberta. In: Holroyd et al. 1991 (above).

2. Areas known to have a concentration of species on the rare plant list include the Cordillera, the Canadian Shield, the southern grasslands, and a diverse area in the southwest corner of the province where several natural regions converge.

Brown, L.P. 1993. Holistic stewardship of prairie fragments. In: Holroyd et al. 1993 (see section $A$ ). 
- Discusses rationale for preserving small patches of prairie in order to conserve biodiversity.

Griffin, D. 1987. Provincial perspectives on public lands-Alberta. In: Holroyd et al. 1987. (above).

Morgan, J.P. 1993. Restoring native prairie ecosystems. In Holroyd et al. 1993 (above).

Moss, E.H. 1983. Flora of Alberta. Second Edition revised by J.G. Packer, University of Toronto Press, Toronto.

Moss, E.H. 1983. Flora of Alberta. Second Edition, revised by University of Toronto Press, Toronto.

Packer, J.G. and C.E. Bradley. 1984. A checklist the rare Alberis. Provincial Museum of Alberta Occasional Paper No

Lists the 360 species of plants consids. In Alberta.

Purdy, B.G. and S.E. MacDonald. 1992. Status resory or the sand stitchwort Stellaria

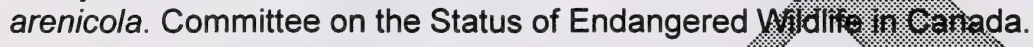

- Restricted endemic of Athabasca sand dunes, $\quad$.

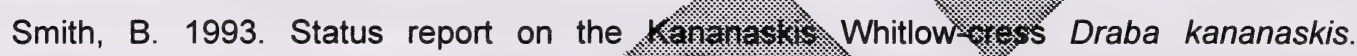

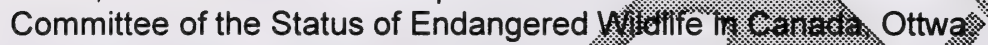

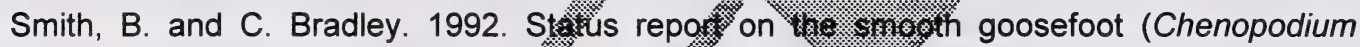

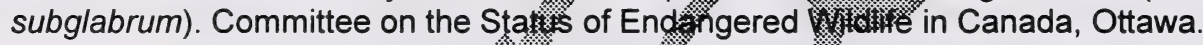

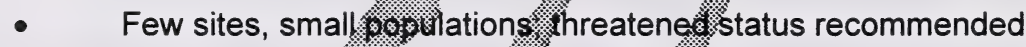

Smith, B. and C. Bradley. 1982. Status sert on the sand verbena (Abronia micrantha).

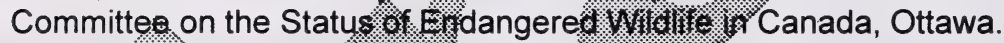

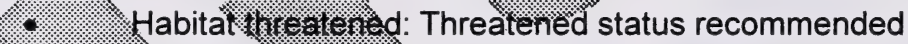

Smith, B. ans.

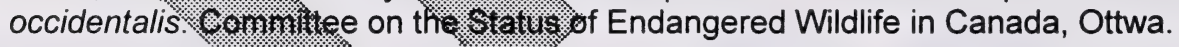

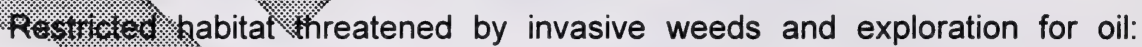
endangeres status recommended

Smilk, B. 1993. Status regent on the little barley (Hordeum pusillum) in Canada. Committee 6. the Status of Endailgered Wildlife in Canada, Ottawa.

- Insufficient information to award status

Walliss, C.L. 198\% Critical, threatened and endangered habitats in Alberta. In: Holroyd et al. (toboves:

lists significant landscape types in mixed grassland, northern fescue grassland, foothills grassland, central parkland and foothills parkland. Notes that $66 \%$ of the mixed grassland and $95 \%$ of upland central parkland and northern fescue grassland has been lost. 


\section{Fisheries}

Berry, D. 1995. Alberta's Walleye management and recovery plan. Alberta Environmental Protection, Natural Resources Service, Fisheries Management Division.

Roberts, W. 1987. The bull trout-endangered in Alberta. In: Holroyd et al. 1987 (above).

Excessive angler harvest is the major factor in decline of bull trout.

Roberts, W. 1991. The bull trout: vanishing from the prairie and parkland of In: Holroyd et al 1991 (above).

\section{Herpetiles}

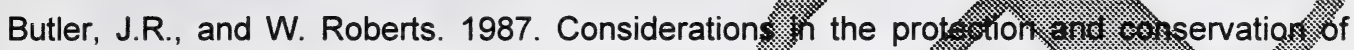
amphibians and reptiles in Alberta.

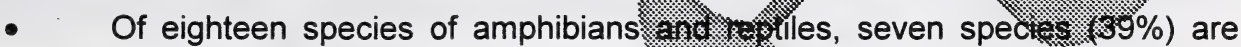

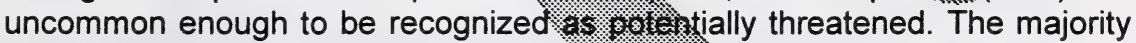
of these species and populations unde. osinged are associated with prairie environments.

Powell, G.L. and A.P. Russel. 1993. The range shortatus of thorned lizard in the Canadian prairies. In Holroyd et. al. $196 \mathrm{~g}$

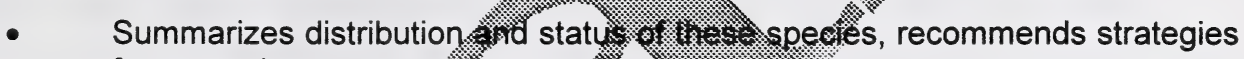
for protection.

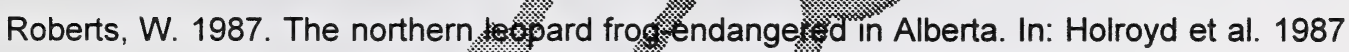
(above).

- Discusses the secline of $=0$ pard f

\section{E. Birds} are uncleak

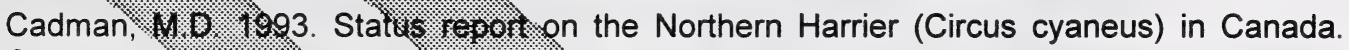

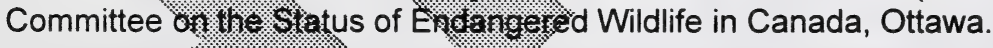

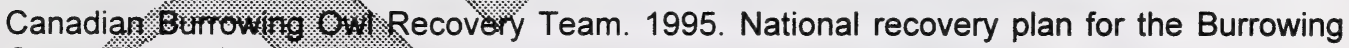

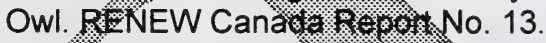

Caknings, R.J. 1992. Salus report on the Sage Thrasher Oreoscoptes montanus in \&anada. Committee on the Stauts of Endangered Wildlife in Canada, Ottawa.

- Small: $\quad$ population in restricted range in threatened habitat: endangered status ressmmended.

Qolven! WI: 1991. Effects of fluctuating wetland conditions on prairie shorebirds. In : (rolroyd ex al. 1991 (above).

- $\quad$ Shorebirds are adapted to a narrow range of water fluctuations; prey species and nesting habitat may decline if water levels vary outside normal perturbations. Habitat and underlying food resources for prairie shorebirds are much less predictable, owing largely to seasonal and annual variations in climate. 
De Smet, K.D. 1992. Status report on the long-billed Curlew Numenius americanus in Canada. Committee on the Status of Endangered Wildlife in Canada, Ottawa.

- $\quad$ undisturbed short and mixedpgrass prairie: recommended status vulnerable

Dickson, H.L. and A. R. Smith. 1991. The western hemisphere shorebird reserve network and the prairie shorebird program. In: Holroyd et al. 1991 (above).

Lists proposed regional shorebird reserves in the prairie provincas

Erickson, G. 1987. Status of Burrowing Owls in Alberta. In: Holroyd 1. (aboove)

Discussion of population and status of Bustowing \&.t.

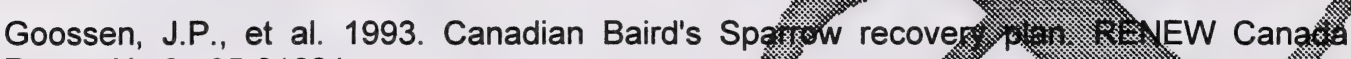
Report No.3., 95-01621

Goossen, J.P. 1991. Prairie Piping Power conse.2. Wildlife Service, Edmonton.

James, P.C. 1993. Habitat fragmentation and Burrows. In Holroyd et al. 1993 (above)

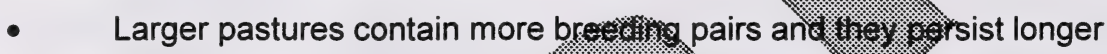

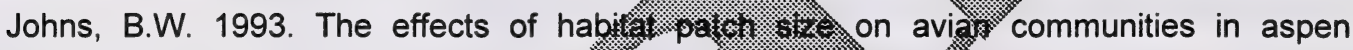
parklands. In Holroyd et al. 1993 (abovo

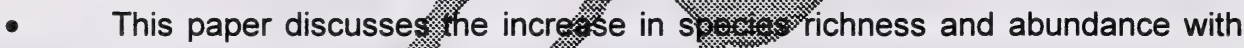
increased habitat size.

Kuyt, E. 1987. Whooping Crapks in: Holrow et al. (above).

Discusses

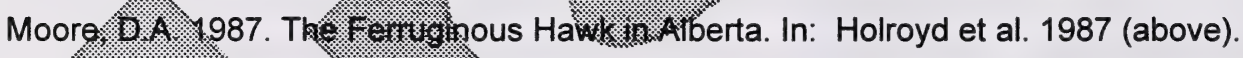

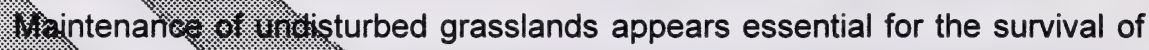
ing

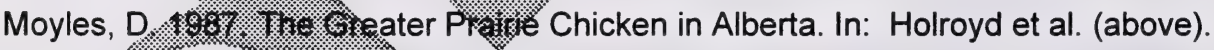

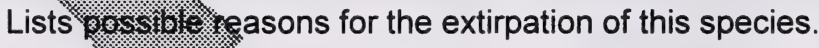

The minn : quirement for reestablishment would be a minimum of 2000 to 4000 of grasslands.

Wodds, T.D. and R/. Clark. 1993. Landscape ecology, adaptive resource management and the North Americas Waterfowl Management Plan (NAWMP). In Holroyd et al (above)

This paper presents an experimental protocol which may contribute to resolving unanswered questions about the efficacy of intensive versus extensive management

Poston, B., D.M. Ealey, P.S. Taylor, and G.B. McKeating. 1990. Priority migratory bird habitats of Canada's Prairie Provinces. Habitat Conservation Section, Canadian Wildlife Service, Western and Northern Region, Environment Canada, Edmonton, Alberta 
Lists migratory bird habitat in Alberta, Saskatchewan and Manitoba

Schmutz, J.R. 1993. Grassland requirements by Ferruginous Hawks. In Holroyd et al. 1993 (above)

- $\quad$ Ferruginous hawks are generally common where a ranching land use prevails

Schmutz, J.K. 1991. Population dynamics of Ferruginous Hawks in Alberta. In: Holroyd et al 1991 (above).

Schmutz, J.K. 1987. Factors limiting the size of the breeding poulations Hawks. In: Holroyd et al. (above).

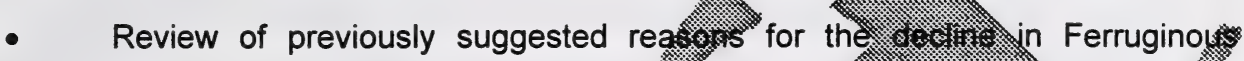
Hawks.

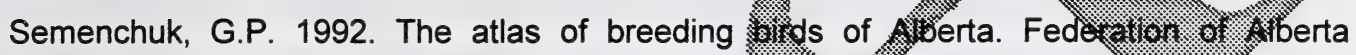
Naturalists, P.O. Box 1472, Edmonton, Alberta. T5 21 ,

- The most comprehensive surveys to date of kiluerta's avifauna.

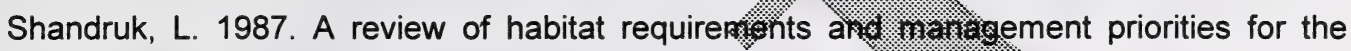

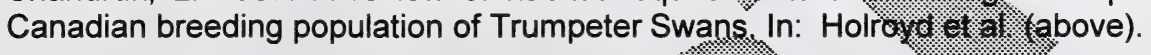

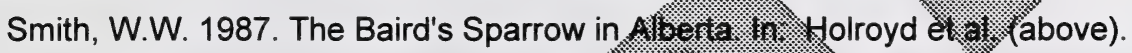

- Discusses distribution a

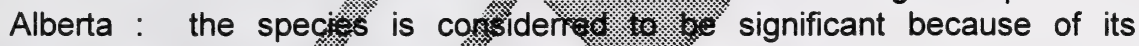

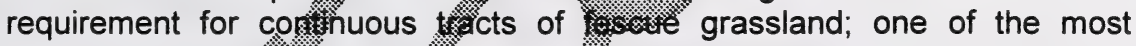

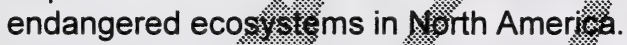

Smith, W.W. 1991. The Loggensuead Shrike in Alberta: In: Holroyd et al. 1991 (above).

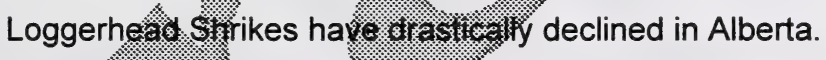

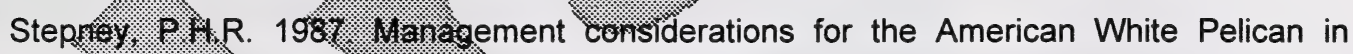

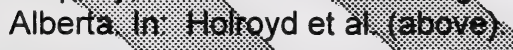

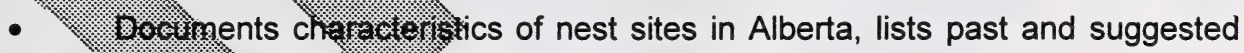

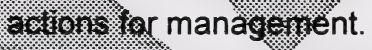

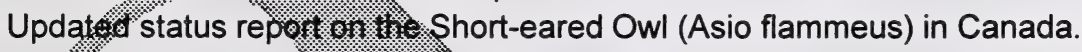

Wesshler, C.R. 1987. The teping plover in Alberta. In: Holroyd et al. 1987. (above).

Discusses habitat, population,limiting factors, etc.

Wershler, C.R. 198\% The Mountain Plover in Canada. In: Holroyd et al. 1987 (above).

Oiscusses habitat, population, limiting factors, etc. of this endangered species; an example of a species with requirements for grassland-interior habitat.

Wershler, C., W.W. Smith, and C. Wallis. 1991. Status of the Bairds Sparrow in Alberta$1987 / 1988$ update with notes on other grassland sparrows and Sprague's Pipit. In: Holroyd et al. 1991 (above). 
Wershler, C. 1991. A management strategy for Mountain Plovers in Alberta. In: Holroyd et al 1991 (above).

- Discusses relationship of grazing pressure to distribution of grassland sparrows.

\section{F. Mammals}

Barclay, R.M.R. 1993. The biology of prairie bats. In Holroyd et al. 1993 (above

- Summarizes biology and habitat, makes recommend $\quad$ Suns further study.

Barrett, M.W. 1987. History and management of the prom it Holroyd et al. 1987 (above).

Discussion of management issues af

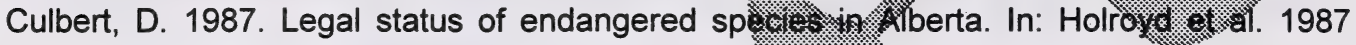
(above).

Dubois, J.1987. Small mammals. In: Holroyd et al. 19.97 k 12001.

Discusses mammal species of concern in the prates onces.

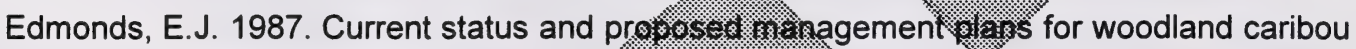
in Alberta. In: Holroyd et al. 1987 (above)

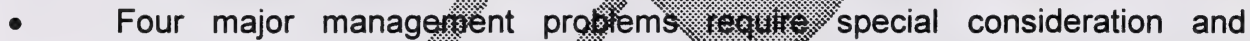
resolution: the destriction an alteration the increased access to caribou caribou to hunity despite. closed siaksons, and the high levels of wolf predation in wess central Atoerta.

Johnson:G., McFetridg6.

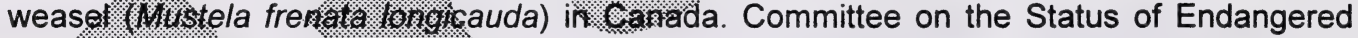

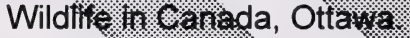

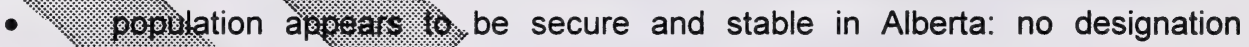

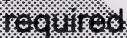

Neitfield: V., J. What Woolnough and B. Hoskin. 1985. Wildife habitat requirement sumraries for selecked wiblilife species in Alberta. ENR Tech. Rep. T/73; Alberta Energy

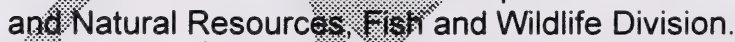

- $\quad$ Provides summaries of key habitat requirements for mule deer, white-tailed deer moose, elk, woodland and mountain caribou, pronghorn antelope, rocky msintain bighorn sheep, mountain goat, grizzly bear, beaver, river otter, marten, sharp-tailed Grouse, Ring-necked Pheasant, Sage Grouse, resident breeding dabbling ducks, breeding Canada Geese, and moulting, staging and migrant waterfowl.

Reynolds, H.W. 1987. The Canadian Wildlife Service program to restore wood bison. In: Holroyd et al. 1987 (above).

Smith, H.C. 1993. Alberta Mammals: an atlas and guide. Provincial Museum of Alberta, Edmonton, Alberta. 


$$
\frac{5 x}{200}
$$





\section{J. Methods to Design and Construct Wetland Systems}

\section{Overview of Design Criteria}

Wetland design criteria requires careful consideration of wetland typenfigsiátion, size, water source, soils, and vegetation. Wetland design methods and criteria are continually being improved. The wetland designer should review the refos included in this manual and obtain reviews from senior wetland design engineers s. all design and constration plans prist to proceeding with construction.

\section{Type}

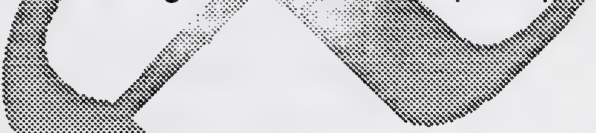

The type of constructed wetland system desired may descrid upon the feasibility of using natural wetlands for treatment, treatment performanee resuituments, estimated cost, and

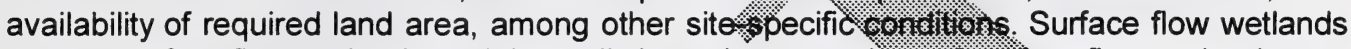

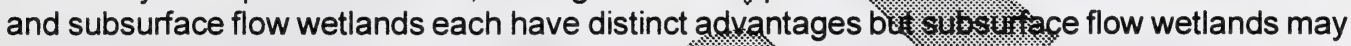
be desired where land is limited or too expensive.

\section{Area}

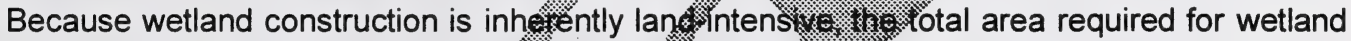
construction may be the single mast importans parametey for wetland feasibility, particularly in urban areas where land is limites. and expisnsive. Sizkg criteria described below should be

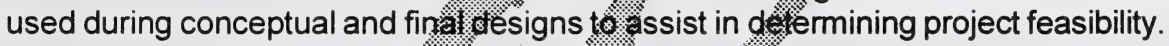

\section{Constructed Wetlands}

Naturat and wonstructed. Wetanots may be used for removal of pollutants from domestic, industrial and non goint souke. wostwater. The area required for a treatment wetland to meet the specific desigr oljectives oferengs on a wide range of factors. Total area required for

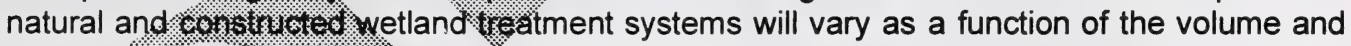
quality of influent to o. re realed, desired wetland effluent quality, and allowable hydraulic loading rate.

Takal wetland area shoula for the pollutant parameter of concern with the lowest pollutant removal efficiency. Wetland area requirements ts: achieve target pollutant concentrations in the effluent are available in Kadlec and Knight:(1996), and WPCF (1990).

\section{Naturat Treatment Wetland Systems}

Cofservative recommended hydraulic loading rates range from $0.2 \mathrm{~cm} / \mathrm{d}\left(50 \mathrm{ha} / 1,000 \mathrm{~m}^{3} / \mathrm{d}\right)$ if pretreatment is secondary without nitrification to $0.5 \mathrm{~cm} / \mathrm{d}(20 \mathrm{ha} / 1,000 \mathrm{~m} / \mathrm{d})$ for nitrified secondary effluent. If concentrations of $\mathrm{BOD}_{5}$, TSS, phosphorous, and other constituents are reduced in pretreatment, the recommended conservative hydraulic loading rate is $2.5 \mathrm{~cm} / \mathrm{d}$ (4 ha/1,000 $\mathrm{m}^{3} / \mathrm{d}$ ) (Kadlec and Knight, 1996). 


\section{Constructed Surface Flow (SF) Wetland}

The typical range of hydraulic loading rates is from 1.5 to $6.5 \mathrm{~cm} / \mathrm{d}\left(6.7-1.5 \mathrm{ha} / 1,000 \mathrm{~m}^{3} / \mathrm{d}\right)$ with a central tendency of $3 \mathrm{~cm} / \mathrm{d}\left(3.3 \mathrm{ha} / 1,000 \mathrm{~m}^{3} / \mathrm{d}\right)$ (Kadlec and Knight, 1996).

\section{Constructed Subsurface Flow (SSF) Wetland}

The typical range of hydraulic loading rates is from 8 to $30 \mathrm{~cm} / \mathrm{d}(1.3-0.3 \mathrm{ha} / 1,00 \mathrm{~g} \mathrm{~m} / \mathrm{d}$ (Kadlec and Knight, 1996).

\section{Stormwater Wetland}

MOEE (1992) recommended that stormwater wetland

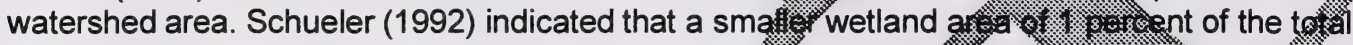

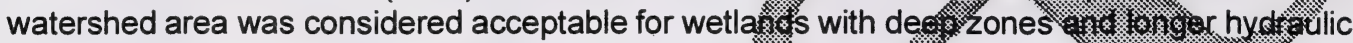

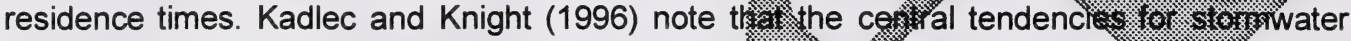
wetlands are similar to those of point source SF wetlabtus:

\section{Configuration}

\section{Constructed Wetlands}

Constructed wetlands are typically designe

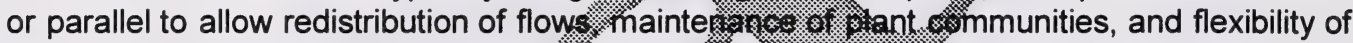
operation (WPCF, 1990). Multiple ingur points an with of the treatment wetland allow for even dist:

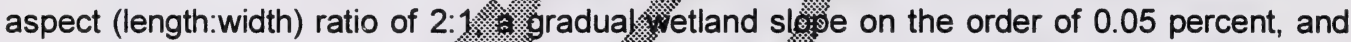

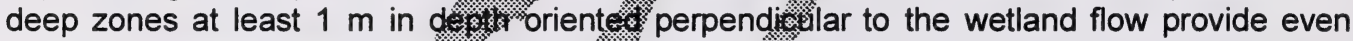
distribution of the wetland flow: (xadlec an:

\section{Water Source and Management}

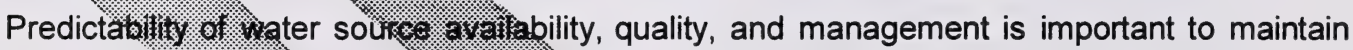
design hydroper.

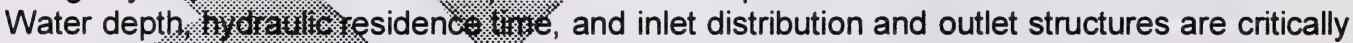

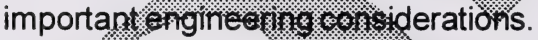

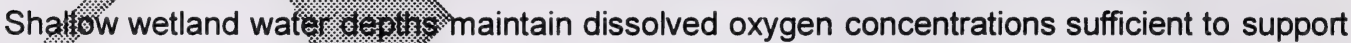
nituffication. For optimisun ofiformance, experience suggests that the average water depth for an SF wetland is 30 s with typical water depths ranging from 0.15 to $0.45 \mathrm{~cm}$ (Kadlec and knight, 1996). SSF wetland water levels are designed to be below the ground surface with a 1.roical bed depth of tess than $0.6 \mathrm{~m}$ and water depths ranging from 0.3 to $0.6 \mathrm{~cm}$ (Kadlec and (ringht, 1996). Netural wetland water depths may vary over a wider range than SF wetlands, 8ut are most: 1. Hective if they do not exceed $50 \mathrm{~cm}$.

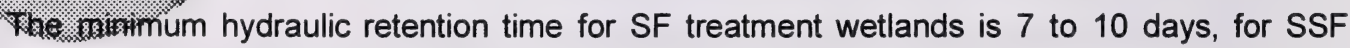
wetlands 2 to 4 days, and 14 to 20 days for natural treatment wetlands are typical (Kadlec and Knight, 1996).

Wetland influent should be provided a minimum of primary treatment in SF and SSF wetlands (WPCF, 1990), and secondary with nitrification and phosphorus reduction in natural wetland treatment systems. 
Water distribution and collection structures should be simple to maintain, operate, and replace. Pipes should be slightly oversized. Trash racks or other suitable barriers should be erected upstream of the distribution system to prevent clogging.

\section{Receiving Water}

The point of discharge from the treatment wetland to the receiving water must, be identified. Effluent discharge criteria will typically be established based on the receiving wal quality.

\section{Soils}

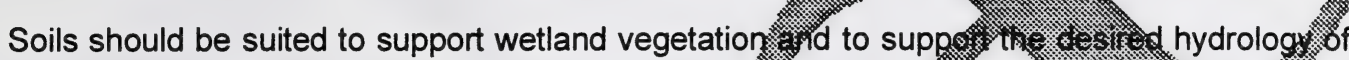

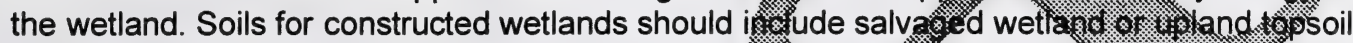

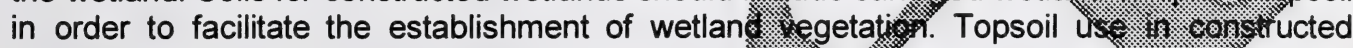

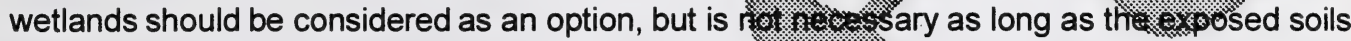

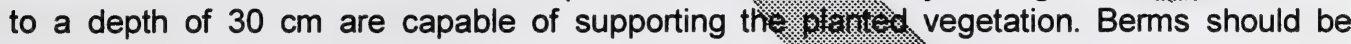
constructed from stable materials and protected by erosis.

\section{Vegetation}

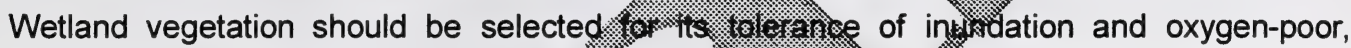
reduced environments. Desirable chara

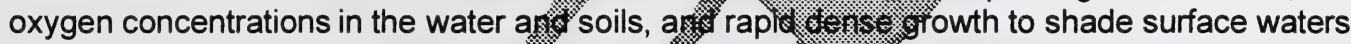

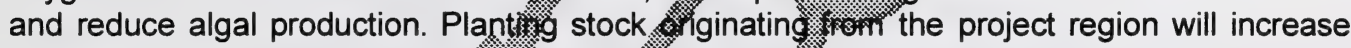
survival potential.

Planting centres may range

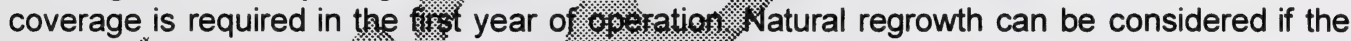
treatment. wetland reguitis

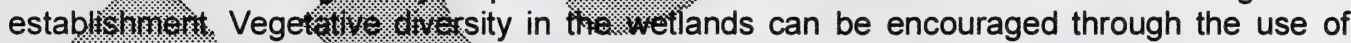

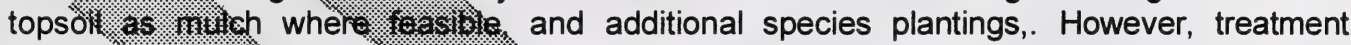

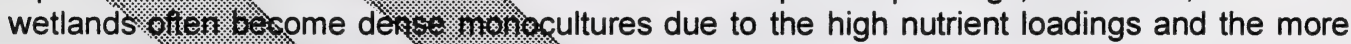

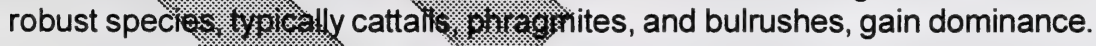

Litter

Exigablishment of the iticy layer may take from 1 year to more than 5 years. Improved sismoval efficiencies in likely be realized if imported litter, such as straw, is placed in the weatment wetland during construction of the system (Kadlec and Knight, 1996).

\section{Feasibillty Analysis and Design}

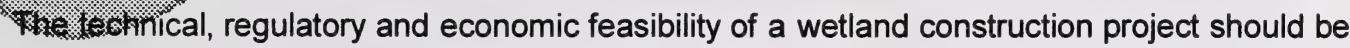
thoroughly evaluated prior to proceeding to final design and construction. It is important that the Owner understand that wetland technology is still in a developing phase, and that it is not possible to predict wetland performance with high precision. It is equally important that the Designer identify and take into consideration existing and known potential constraints to successful wetland construction and operation in order to provide reasonable assurance that 
project objectives will be met. The following section outlines the basic stages and information needs of a wetland construction feasibility analysis. It is assumed that the goals and objectives of the project have been clearly identified and agreed to by the Owner, designer, and concerned regulatory staff, if applicable, as described earlier.

\section{Site Selection}

Selection of an appropriate location for wetland construction should be based of identified alternative locations and the extent to which they satisfy requirements, or criteria.

\section{Site Selection Criteria}

The successful location of a wetland construction

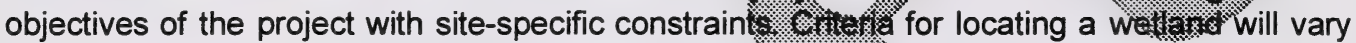

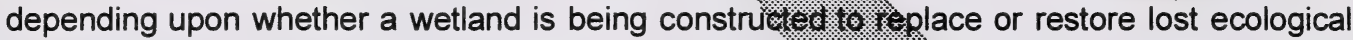
functions or enhance existing wetland functions, or whettue. a wetland is being constructed or

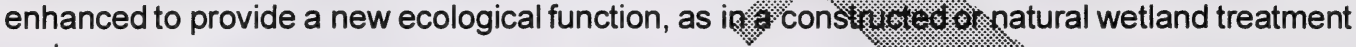
system.

Possible wetland site selection criteria may incisis: of

- Proximity to desired locatis

- Availability of sufficieng contigusis area.

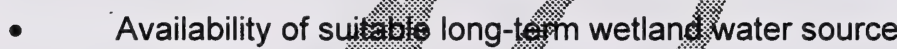

- Favourable sitergydrogeglogy

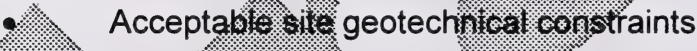

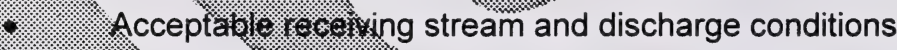

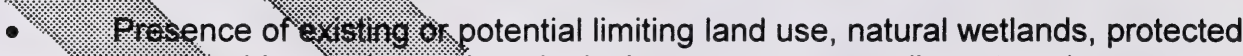

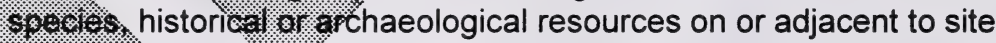

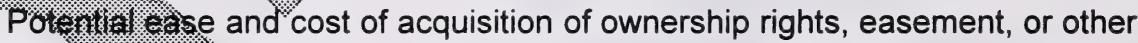
controbling

- $\quad$ Ease बैacess for construction and maintenance

- $\quad$ Availability of sufficient construction materials and labour resources

\section{Proximity}

Wis criterian will vary depending upon the type of wetland to be constructed. Wetlands desicnge: to mitigate for total or partial loss of function may need to be constructed in the vicinity of the original wetland ("onsite" vs. "offsite"). Wetlands designed for stormwater treatment may need to be located at an appropriate topographic elevation in order to maximize gravity flow. Natural and constructed wetland treatment systems may need to be designed on or adjacent to the location of the pollution source in order to minimize land and pumping costs, and to control or limit public access. 


\section{Area}

Total area requirements will vary with wetland goal, but in general, sufficient contiguous area should be available to allow the wetland to be constructed at one location to minimize construction, operation and maintenance costs. Preliminary estimates of the required area may be determined for the Site Selection Phase as described below under subsection "Conceptual Design".

\section{Wetland Water Source}

Treatment wetlands viability will be determined by the continued water effluent.

\section{Hydrogeology}

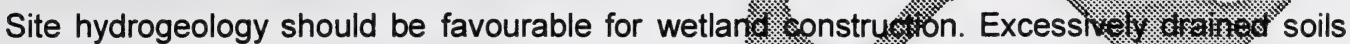

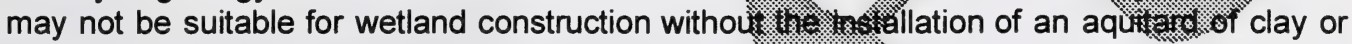
other materials of low hydraulic conductivity. Shallow de of wis s the surface of bedrock may also constrain wetland excavation.

\section{Geotechnical Constraints}

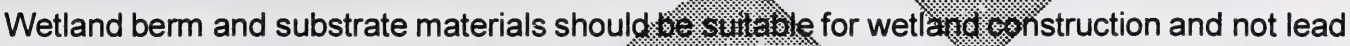

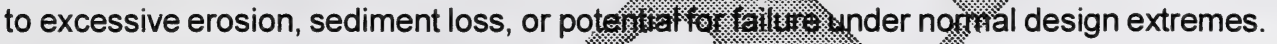

\section{Limiting Land Uses and Other Siting Constraints}

Human land use may constrain the suitability of a wetland construction location. Care should be taken to locate the wetland ris. recognition of the wetland desizs goals. The presense of natural wetlands, protected species habitats, and historical or archiseologicalissources on or adjacent to site may pose additional significantesign constrainto 6

\section{Owreiship and Land orst}

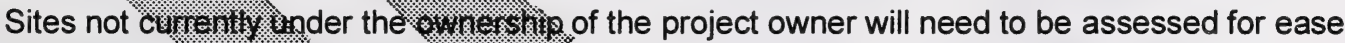

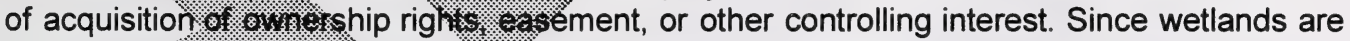

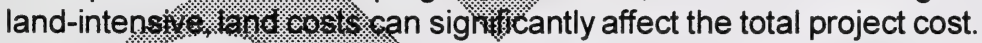

\section{Access}

Fiach site should be exaluzited for existing and potential ease of access for construction and fir ure maintenance. Kocal land use regulations should be consulted to identify possible asenstraints to constriction and maintenance traffic.

\section{Materials}

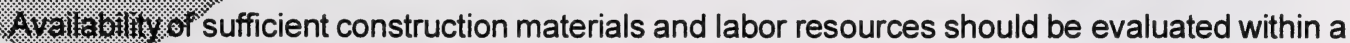
regional context in order to minimize project cost and to maintain standards of quality for materials. The availability of skilled contractors, plant nurseries, and acceptable wetland construction materials should be assessed. 


\section{Data Collection}

Sufficient data should be collected from each proposed construction site(s) to respond to the information needs of site-selection criteria, and to evaluate the potential for successful wetland permitting, construction and operation. Task 1 of this manual provides a checklist of information categories that will provide useful information for site selection, wetland design, and construction.

\section{Site Selection}

The site selection process should result in the selection of a location

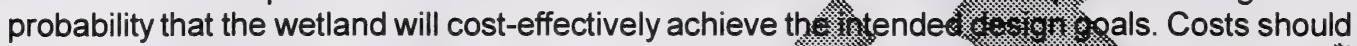
include long-term operations and maintenance costs $/$ s.s. vell as inj: costs.

\section{Constructed Wetlands}

The site selection process for constructed wetlansis. 2018 is id emphasize identification and

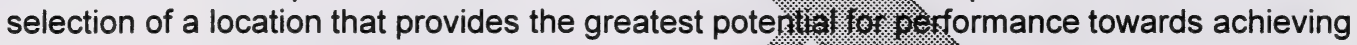

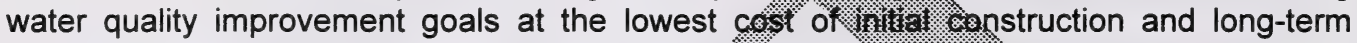
operation and maintenance. Selection of a suitable site for wankitivetion of a natural wetland

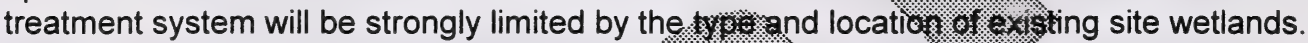

\section{Conceptual Design}

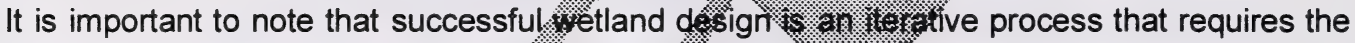
technical input of biologists, enginee, construstion conks. the project Owners. A conceptual design shoild be presared during the site selection process with available information in afow to actieve the oreatest realism in site selection. Key conceptual design elements iscide an asosoximate vetermination of wetland area, hydrologic requirements, ability to meet performanesentestives, and cost of land and construction. These are disctissed below by wistand type.

\section{Area}

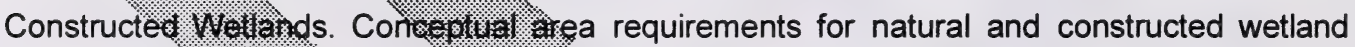
treatment systems 1 inguld be conservatively determined as a function of hydraulic loading rate,

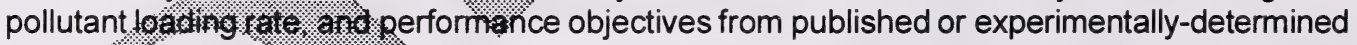
desighoriteria.

Types of information thav. will be needed to determine this criterion for the Conceptual Design Thase include the average influent water quality and flow rate, effluent water quality objectives and flow limitations, and receiving water quality and hydraulic capacity. Results of more detailed pollutant mass balances are required during the Final Design Phase to determine which pollutant willy require the most area to achieve the wetland water quality objectives.

\section{iydrology}

Constructed Wetlands. Most inflow to natural or constructed wetland treatment systems is predominantly treated wastewater, and water balances may not need to be calculated unless site soil permeability is potentially great enough for infiltration to be a significant hydrologic output from the wetland, or groundwater quality concern. A reliable and controllable hydraulic loading rate is the critical conceptual hydrologic design criterion for constructed wetlands. 


\section{Wetland Performance Objectives}

\section{Constructed Wetlands}

Most natural or constructed wetland treatment systems will be designed to remove as much of a particular nutrient or suite of pollutants from wastewater as possible. Performance objectives in the form of mass removal rates should be established early in the Conceptual Design process to guide wetland sizing and configuration.

\section{Cost Estimates}

Conceptual estimates should be prepared for land costs base thoof local real estate appraisals (if necessary), earthwork costs based upor approxinato an and fill volumes,

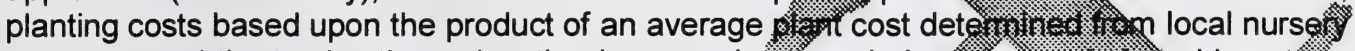
operators and the total estimated wetland area, culvens and pipes as neade. and long-titm operations and maintenance costs.

\section{Regulatory Feasibility and Permitting}

\section{Regulatory Feasibility}

\section{Regulatory Jurisdiction Determination}

A master list of regulatory agency jurisdictiors should be prepared and specific information needs and design constraints identified.

\section{Meeting}

Meetings should be held with regtlatory asency staf prior to permit submittal to confirm jurisdiction and permit information requirerients. Returis correspondence should be requested that verifies topics covered and conclusions drawn from each meeting.

\section{Fatal Flaw Analysis}

Fatal flaws in the wetland desion or construetion possibly resulting from regulatory restrictions should be identified through neethings with regulatory agency staff.

\section{Permitting Requirements}

Provincial and muticipal constraints and requirements on wetland construction should be thoroughtly investigated or or to beginning final design.

\section{Final Design}

Final design should essentially be a much more detailed presentation of the accepted concepwat design, in conformance with such comprehensive guidance as Kadlec and Knight (1996) and WPCF (1990). Detail on earthwork calculations, hydraulic characteristics, slopes, depths, and oosstble site constraints should be developed into a detailed construction package. Emphasis on detail should be placed on hydraulic structures and overall simplification of operation and maintenance requirements. Regulatory confirmation of design details should be sought prior to completion of the final design. A senior review by a qualified treatment wetland designer should be conducted of the complete design. 


\section{Construction Management and Monitoring}

\section{Construction Plans and Specifications}

Wetland construction plans and specifications should be sufficiently detailed for bidding purposes, engineering and biological review, and verification of "as-built".

\section{General}

Wetland construction plans should include a table of contents, a detailed locationap, a sheet key index, and a table of quantities. Individual sheets should includ \#coms ass arrow, scale bar, date of preparation, and a record of reviewers and revision date.

\section{Aerial Photography}

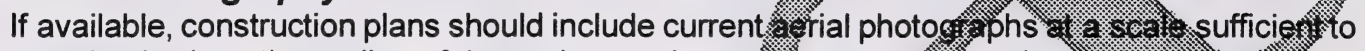

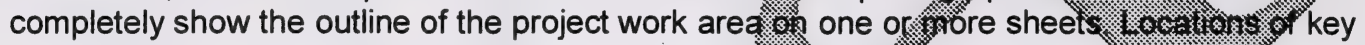

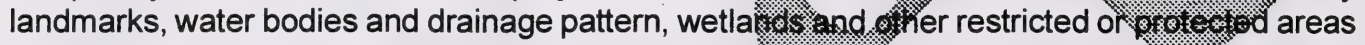

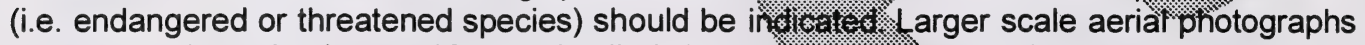

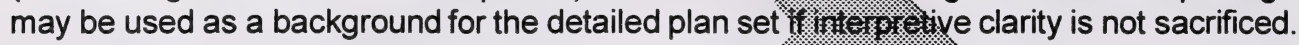

\section{Scale}

A scale of $1 \mathrm{~cm}=10 \mathrm{~m}$ or larger (i.e. $1 \mathrm{~cm}=5 \mathrm{~m}$ ) is recommendics:

\section{Topography}

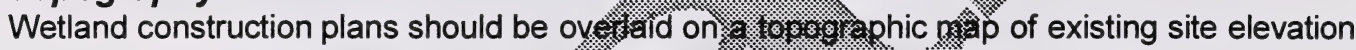

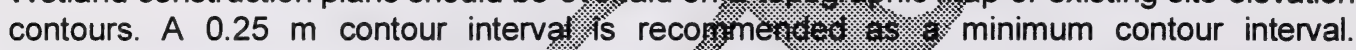
Benchmark location and elevations st.

\section{Geotechnical Information}

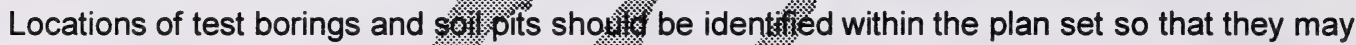

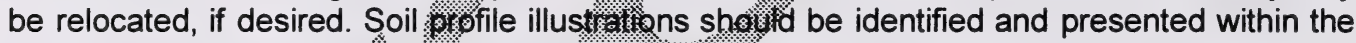

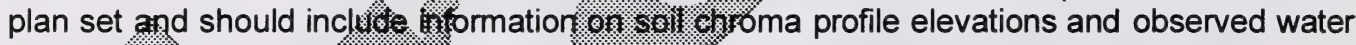
elevations.

\section{Jurisdictional Wetland Boundaries}

Jurisdictional wetand bountranies. stould be clearly and accurately identified on the site

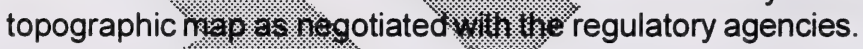

\section{Hydrology}

Plans. should indicate existing and expected water levels, identify adjacent water bodies and to establish major surfa. of stainage patterns at the construction site. All elevations should be matede relative to National Eeodetic Vertical Datum (NGVD), or an elevation conversion should oe supplied. Site hydisglogical data should include seasonal high and average water elevations atetermined from vegetative indicators, soil indicators, or hydrological monitoring data for existing wetlands. If any, and at adjacent upland sites. Sufficient information should be seveloped to\% oftermine seasonal elevations of receiving waters. If necessary and feasible,

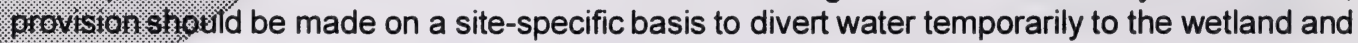
o\&aswusting temporary or permanent structures to provide inundation.

\section{Planting Specifications}

Construction plans should indicate zones or areas to be planted. A planting list should be prepared for each wetland zone that includes quantities, elevation ranges, and acceptable conditions. Special considerations or requirements should be noted and described in sufficient detail. These may include fertilizer specifications, pre-planting conditioning, geographic 
constraints on plant sources, performance and irrigation requirements. Plants should be planted at intervals sufficiently dense to assure rapid growth of vegetative cover.

\section{Vegetation Maintenance}

Construction plans should require control of exotic or nuisance plants within the wetland during and after construction. Details on control methods should be provided for expected nuisance species. Control of herbivory by animals may be required and should be anticipated in the construction and monitoring phases. Provisions should be made for irrigation during construction with available effluent for constructed wetlands.

\section{Land Use}

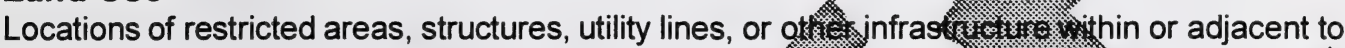

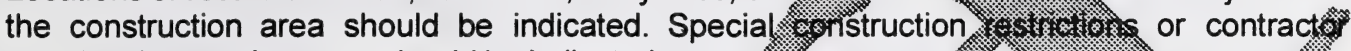
coordination requirements should be indicated.

\section{Erosion and Sediment Control}

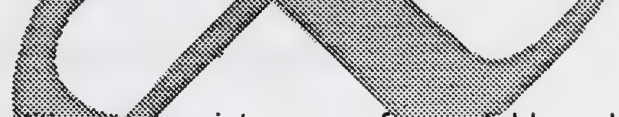

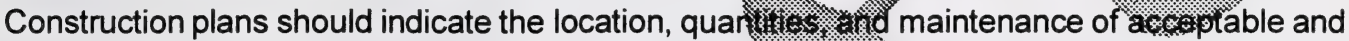
appropriate sediment control methods. Possible seding nut warriers include staked haybales, geotextile silt-screens, sod, and plant seeding. Barriers. 3.0.1.t. be placed at the construction periphery and within the wetland in such a manner wetland berms or edges.

\section{Grading Plan}

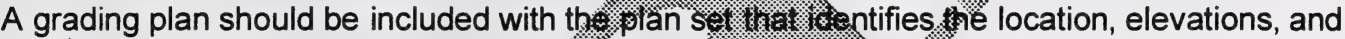

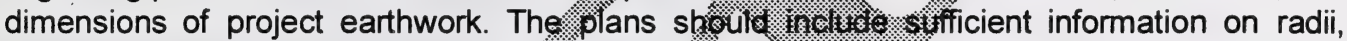
turning points, and baseline offsets fo: Plans should specify soil quality reck irements. soil sour s.s and disposal areas, and means of

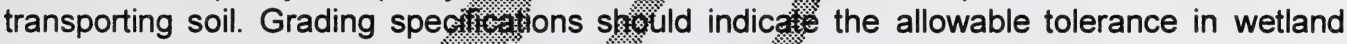
grade elevation. Constructed witkands requike strict adiserence to wetland grade specifications.

\section{Site Preparation}

Construtation plans shoild indude removing the top $0.45-0.6 \mathrm{~m}$ of substrate from the project site and stockpiling of that material to use as cover for the site to provide a seed bank or propagelles source

\section{Contractor Selection Oriteria}

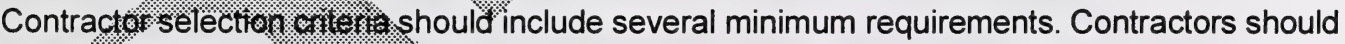

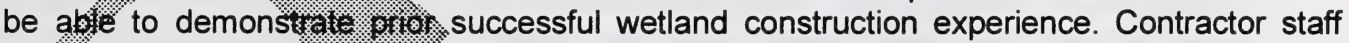
showild include a persion. witu background in wetland creation/restoration design with practical vetland construction experience. The contractor or contractor's insurer should be able to secure a performanse bond equal to the cost of construction, planting, and a period of maintenance and monitoring.

\section{Waintenanes During Construction}

Nustance and exotic plants should be controlled during wetland grading and planting. Trash andifitter should be prevented from accumulating in the wetland. Wetland vegetation should be irrigated or kept watered as needed during the first year initial dry season if not inundated to design depths. Water control structures and culverts should be kept free of debris and soil, and repaired if broken. 


\section{"Time Zero" Report and Final Record Drawings}

"As-recorded" drawings should be prepared and certified by the earthwork contractor or general contractor prior to installation of planting materials, and submitted for approval and acceptance by the project engineer. Final "as-recorded" drawings should be prepared at the conclusion of construction that verify design elevations, water depths, and elevations and extent of planting zones. These should be submitted with a "Time Zero" Report at the completion of the project, which would include descriptions of the major wetland plant communities, densities, species and photographs taken at a sufficient numb of stations to adequately cover the project (Erwin, 1991).

Original mylar or other media should be annotated and s.t.

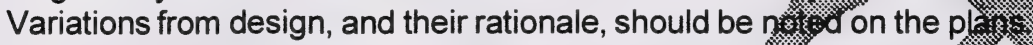

\section{Post-Construction Monitoring}

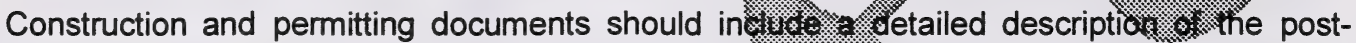
construction monitoring required to measure and evatuz w. whether a wetland has attained its intended goals. Sampling methods, frequency, and momolum station locations should be

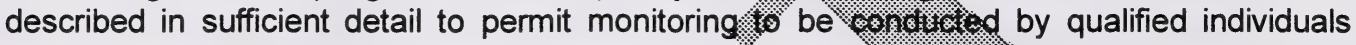
unfamiliar with the project. Monitoring plans should include des.8. of collecting data on water levels and plant spext.

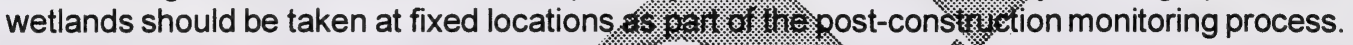

\section{Monitoring Options}

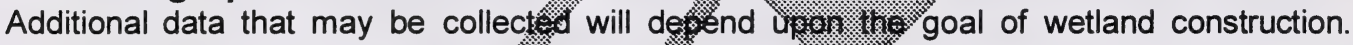

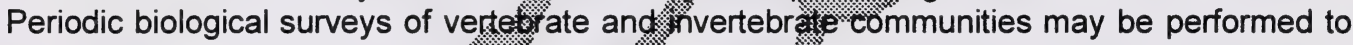
document wildlife habitat and efsisigical poductivity ir the wetland. Water quality sampling may be performed to documesu. pollutant assimilation: organic matter production and export, and sediment retention. F(owd retention, and sfsoundwater recharge functions may be

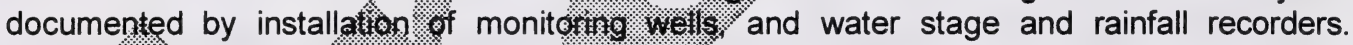

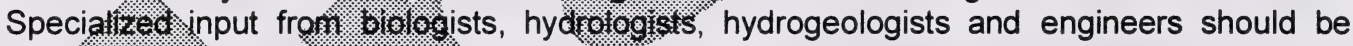

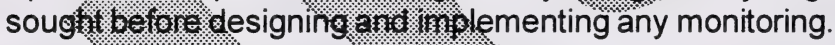

\section{Performance Oriteria}

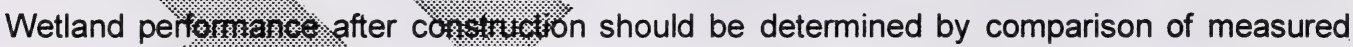

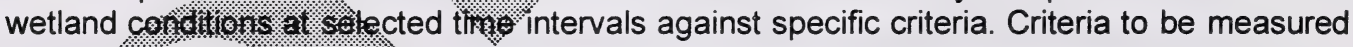

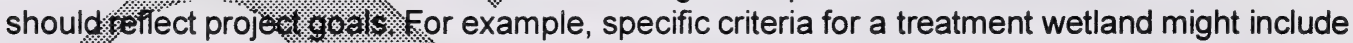
targes effluent concantutum and expected pollutant removal efficiency, as well as other infications of wetland wordigion, such as percent cover by planted and volunteer plant species.

\section{Yietland Maintenance}

- orrective action skould be taken if monitoring indicates that performance criteria are not being met or if other: indications are found that the wetland is not functioning as designed. 0.8nctructed * *iands performance can be adversely affected by inundation less than or 3reater. 13an required by design. Flow, residence time, pollutant removal efficiency, and vonglistiarce with wetland discharge standards may be adversely affected. Wetland vegetation may be adversely effected. Possible solutions may include changing the volume, quality or timing of water deliveries to the wetland, the invert elevations of water control structures, the wetland grade elevation, and the species of vegetation to be planted. 


\section{References}

Erwin, K.L. An Evaluation of Wetland Mitigation in the South Florida Water Management District. Volume I. Contract No. C89-0082-A1. 1991.

Kadlec, R.H. and R.L. Knight. Treatment Wetlands. Lewis Publishers Co. 1996.

Schueler, T.R. Design of Stormwater Wetland Systems: Guidelines for Creating Diverse and Effective Stormwater Wetlands in the Mid-Atlantic Region. Metropolitan Washon Council of Governments. Washington, D.C. 1992.

Water Pollution Control Federation. Wetland Systems chaptep * : Wural Systems for Wastewater Treatment MOP FD-16. Alexandria, VA. 16.

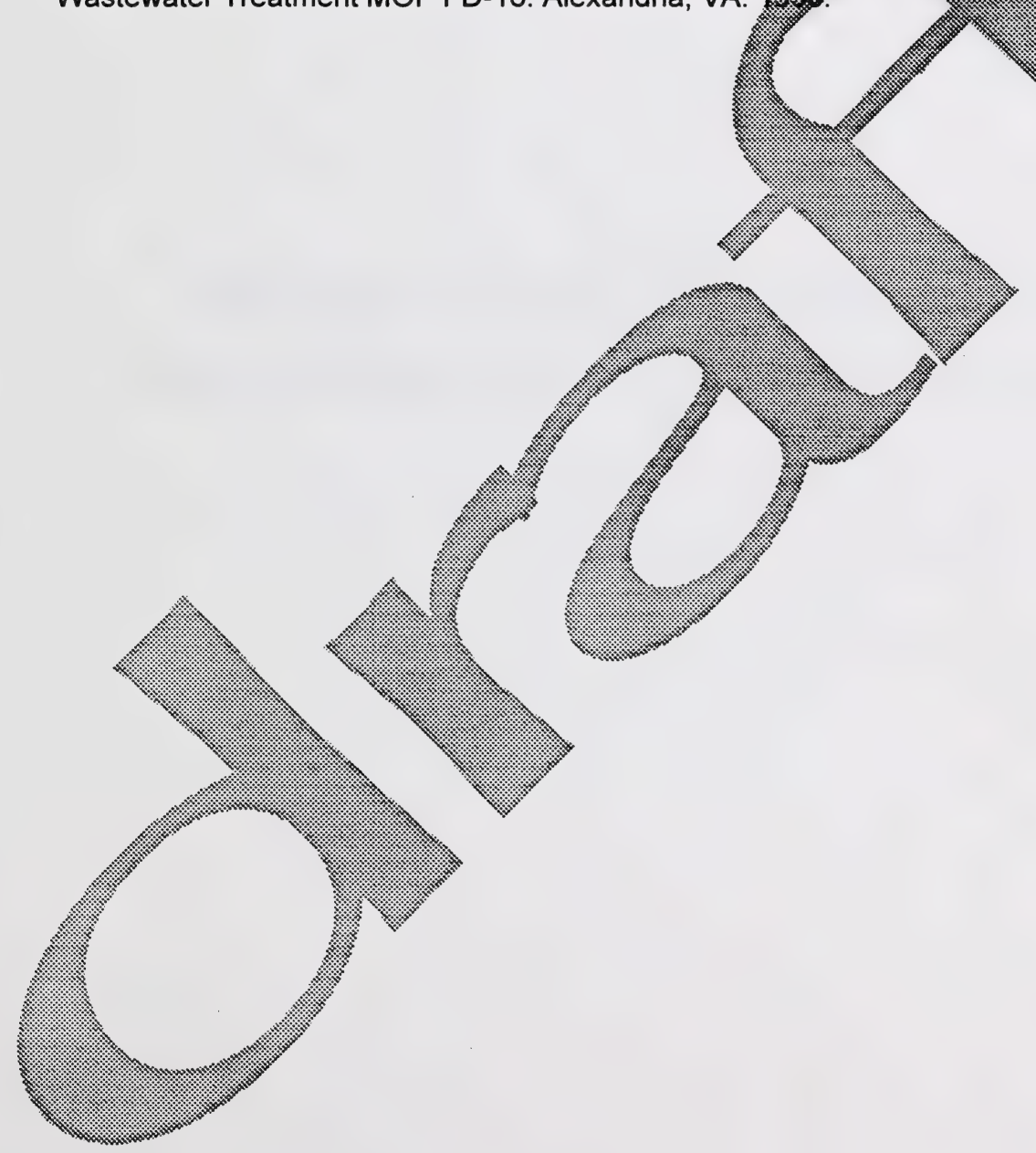





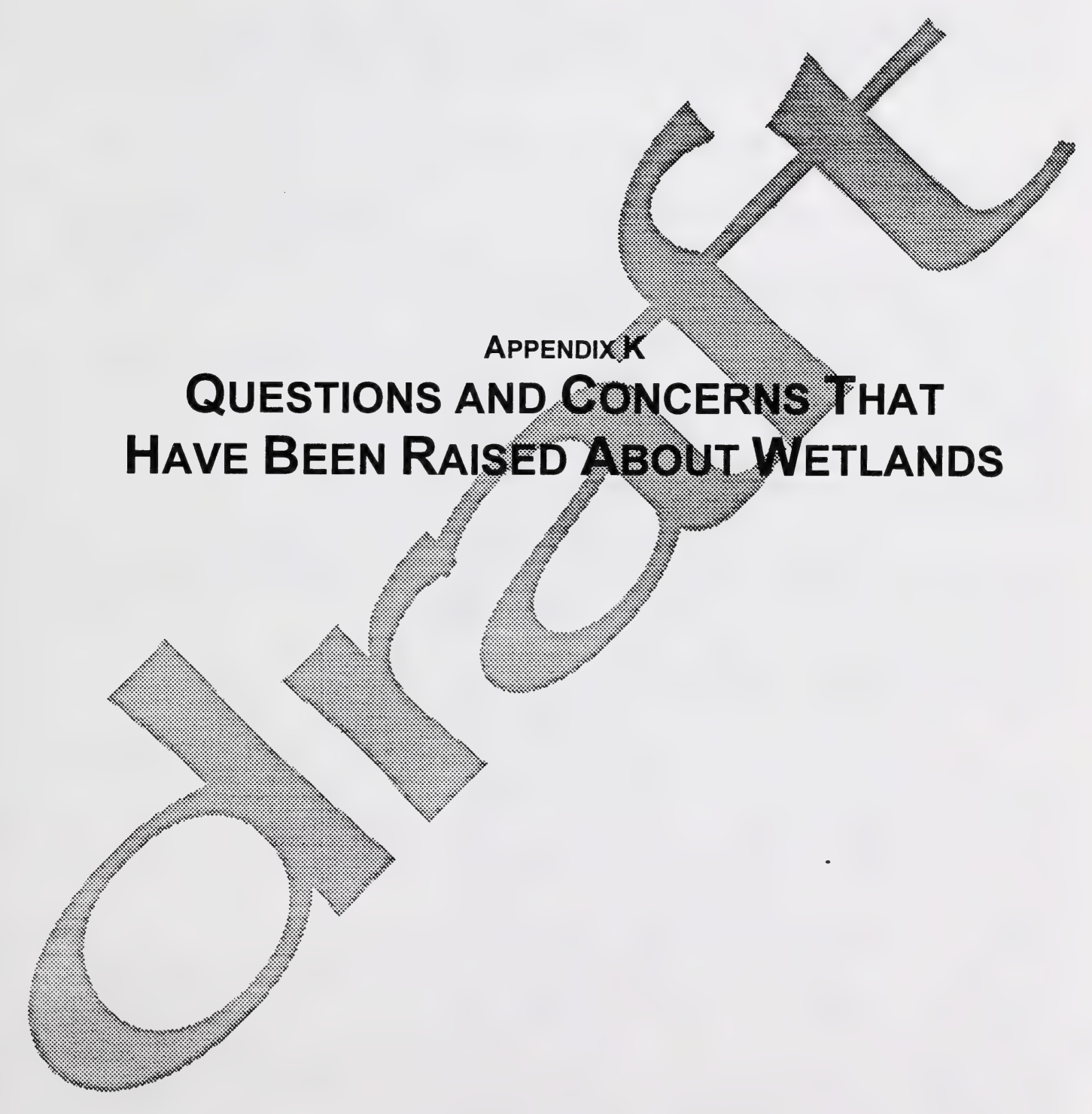





\section{K. Questions and Concerns That Have Been Raised About Wetlands}

Over the years, numerous questions and concerns have surfaced with respect to the longterm effects of wetlands on wildlife and on local residents whose homes are lsicated close to a wetland site. Some of those questions and the response to each the engineers are presented in the following table.

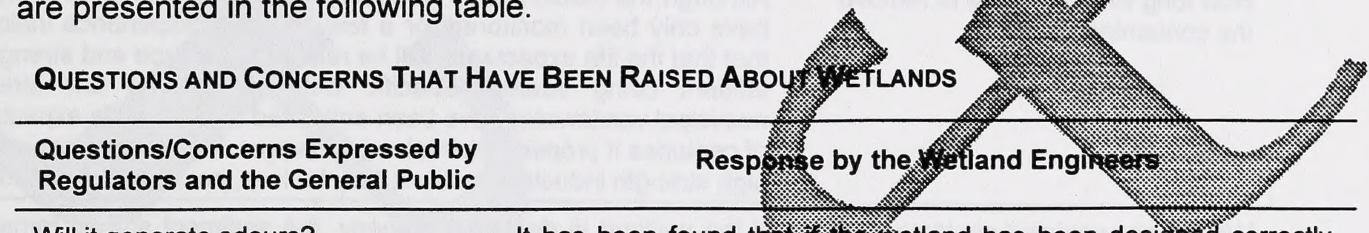

Will it generate odours?

It has been found thras then designed correctly,

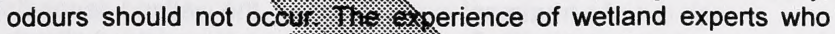
have visited wetland. generation in constris.

What about mosquitos?

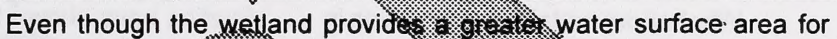

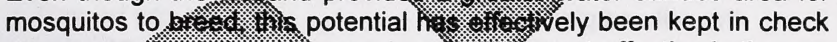

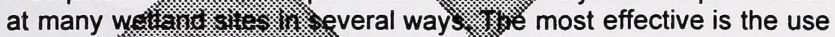

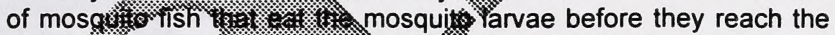
adult Kage. Nes gorple martins and

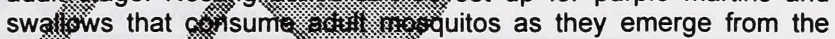
we wand. Main stagnant squito haring sites.

\begin{tabular}{|c|c|}
\hline $\begin{array}{l}\text { Do we know enough about this } \\
\text { technology? }\end{array}$ & 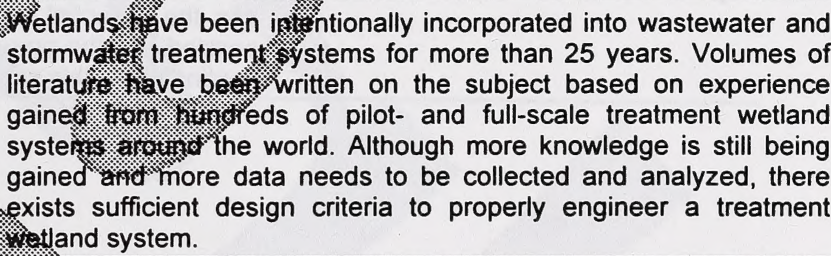 \\
\hline Will it work in & $\begin{array}{l}\text { ynctions of a wastewater or stormwater treatment system that } \\
\text { adsorption) are unaffected by the water temperature. This would } \\
\text { include parameters such as biochemical oxygen demand }\left(\mathrm{BOD}_{5}\right) \text {, } \\
\text { total suspended solids (TSS), and total phosphorous (TP) removal. } \\
\text { However, the treatment functions, such as ammonia nitrogen }\left(\mathrm{NH}_{4}-\right. \\
\mathrm{N} \text { ) and nitrate and nitite nitrogen }\left(\mathrm{NO}_{3}+\mathrm{NO}_{2}-\mathrm{N}\right) \text {, that rely on } \\
\text { microorganisms for contaminant reduction are affected by tempera- } \\
\text { ture and this must be factored into the design of the wetland system. }\end{array}$ \\
\hline 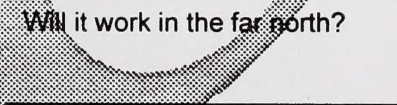 & $\begin{array}{l}\text { The application of wetlands in cold climates has successfully met } \\
\text { effluent criteria across Canada as far north as the Yukon and the } \\
\text { Northwest Territories. }\end{array}$ \\
\hline $\begin{array}{l}\text { chell } \\
\text { chemical types? }\end{array}$ & $\begin{array}{l}\text { Wetlands have been used to effectively treat a wide range of muni- } \\
\text { cipal and industrial effluents. Each waste stream requires careful, } \\
\text { individual consideration. Concentrations and types of chemicals that } \\
\text { have not been tested in a biological wastewater treatment system } \\
\text { should be approached with the same caution that would be exercised } \\
\text { when determining the most appropriate conventional wastewater } \\
\text { treatment system for a given wastewater. }\end{array}$ \\
\hline
\end{tabular}

Will this technology be applicable to There are many potential wetland applications. However, experience 


\section{Questions and Concerns That Have Been Raised About Wetlands}

\section{Questions/Concerns Expressed by}

Regulators and the General Public

all situations?

\section{Response by the Wetland Engineers}

has shown that after carrying out an initial investigation, only about $50 \%$ of the potential sites would be considered feasible for the treatment wetland technology.

Has this technology been applied to a large-scale installation?

How long will it continue to remove the contaminants?

In Canada, at Frank Lake, Alberta, a 1246 ha systam has been installed to treat municipal and industrial tertiary tresid effluent.

Although the oldest known treatment intly in operation have only been monitored $\%$ or a few \& . . . experience indicates that that the life expectarix : .

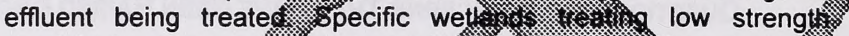
municipal wastewater.

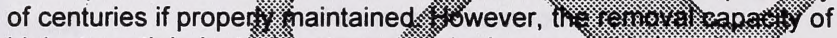
high strength indust

What about metals accumulation in
Will the accumulated contaminants wash out of a treatment wetland system during rainstorms? the soil and plants?

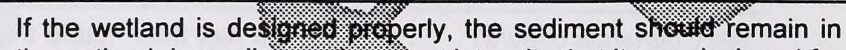

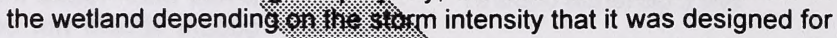

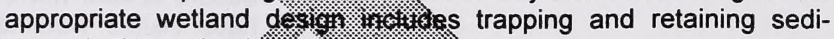
ments in the wetland:

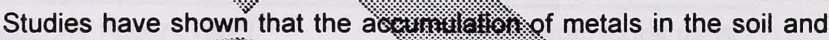

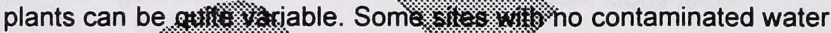
flow showed those in detern the in envisinment.

Will the wildlife be adversely affected by the accumulated contaminants?

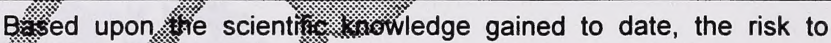
. Ias the bontial to bome a problem, measures can be incorporated. contingiston this son

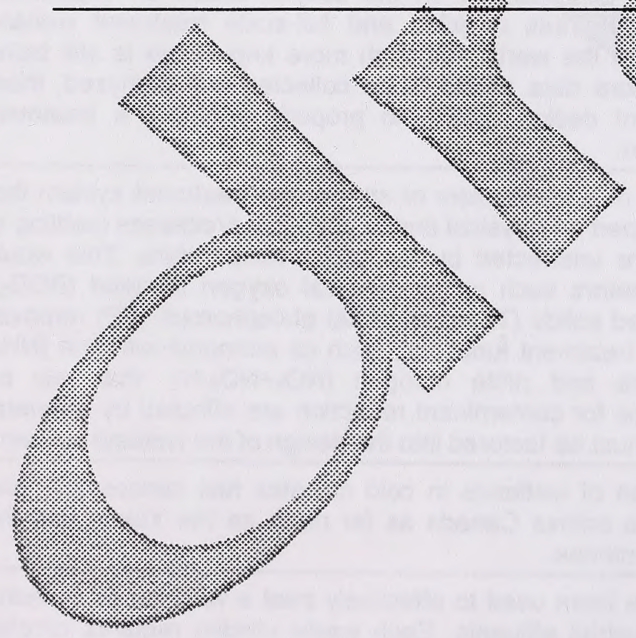



National Library of Canada Bibliothèque nationale du Canada

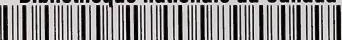

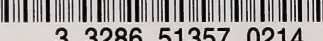

33286513570214 